\title{
Oligocene Marine Mollusks from the Pittsburg Bluff Formation in Oregon
}

GEOLOGICAL SURVEY PROFESSIONAL PAPER 922

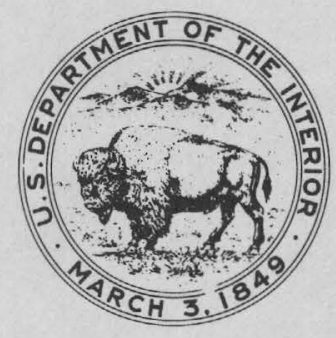





\section{Oligocene Marine Mollusks from the Pittsburg Bluff Formation in Oregon}

By ELLEN JAMES MOORE

GEOLOGICAL S URVEY PROFESSIONAL PAPER 922

Systematic paleontology and stratigraphic

relations of the mollusks_-48 species

representing 31 families are described;

6 taxa are new

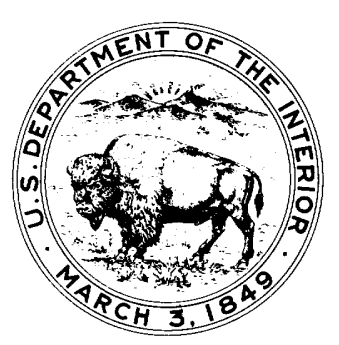




\section{UNITED STATES DEPARTMENT OF THE INTERIOR}

THOMAS S. KLEPPE, Secretary

\section{GEOLOGICAL SURVEY}

V. E. McKelvey, Director

Library of Congress Cataloging in Publication Data

Moore, Ellen James

Oligocene marine mollusks from the Pittsburg Bluff Formation in Oregon.

(Geological Survey Professional Paper 922)

Bibliography: p. 56-60.

Includes index.

Supt. of Docs. no.: I 19.16:922

1. Mollusks, Fossil. 2. Paleontology-Oligocene. 3. Paleontology-Oregon. I. Title. II. Series. United States. Geological Survey Professional Paper 922. QE801.M774 $564^{\prime} .09795$ $76-608010$

For sale by the Superintendent of Documents, U.S. Government Printing Office Washington, D.C. 20402

Stock Number 024-001-02775-5 


\section{CONTENTS}

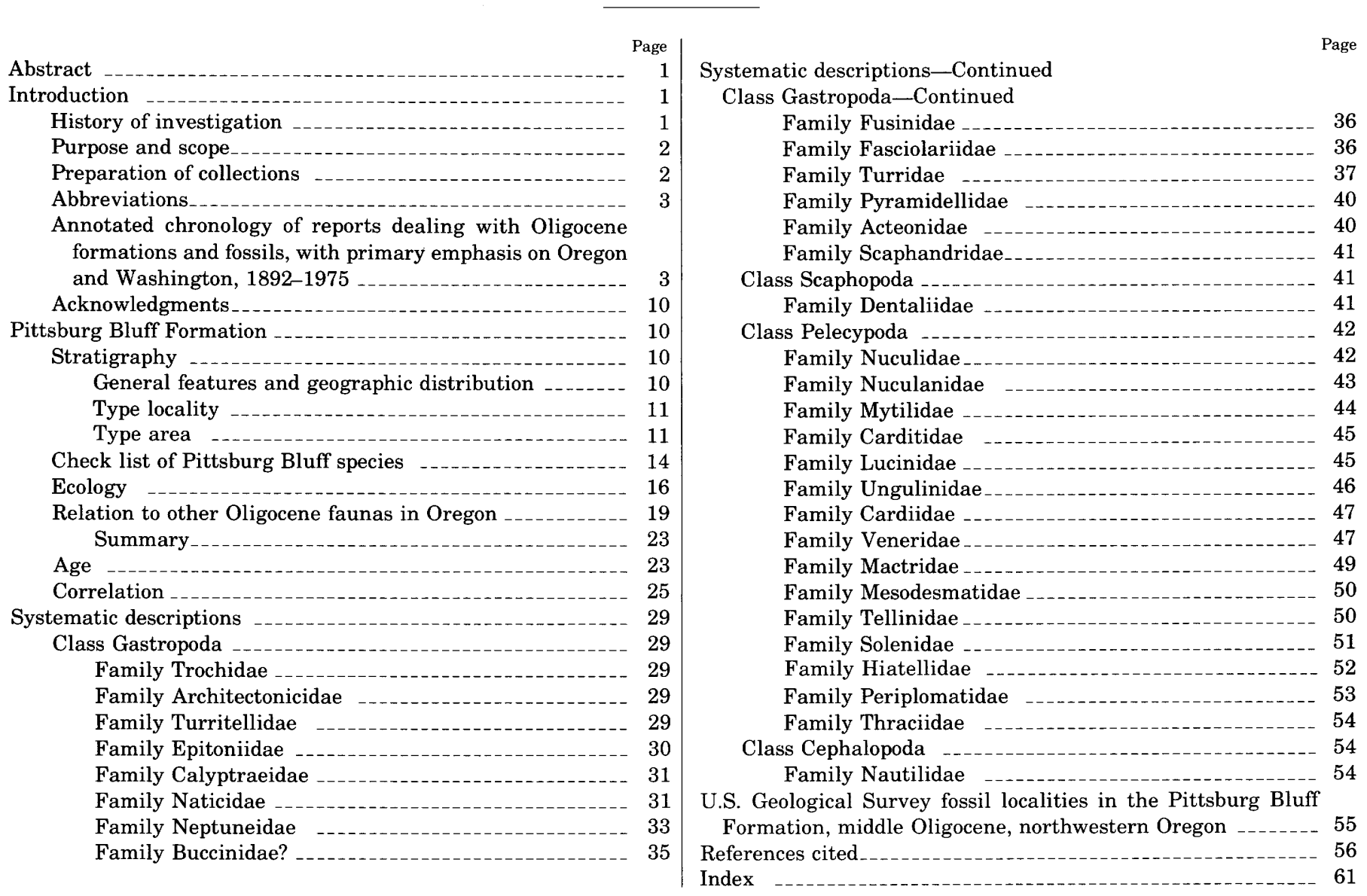

\section{ILLUSTRATIONS}

[Plates follow index]

Plate 1. Architectonica, Crepidula, unidentified trochid?, Cryptonatica, Sinum, and Polinices.

2. Neverita.

3. Bruclarkia, Opalia, Odostomia, Turritella, and Priscofusus.

4. Eosiphonalia.

5. Molopophorus.

6. Perse.

7. Spirotropis, Taranis, Suavodrillia, Dentalium, Scaphander, Acteon?, Acteon, and Aforia.

8. Acila and Nucula.

9. Litorhadia, Cyclocardia, and Yoldia.

10. Lucinoma, Felaniella, and Nemocardium.

11. Tellina? and Tellina.

12. Pitar, Callista, and Crenella.

13. Solena and Solen.

14. Spisula.

15. Panopea and Aturia.

16. Thracia, ?Ervilia, and Cochlodesma.

17. Naticids, Molopophorus, Perse, Acila, and Macrocallista. 
Figure 1. Map showing location of area of study at Vernonia, Oreg

2. Photograph showing type locality of Pittsburg Bluff Formation

3. Geologic sketch map of the Vernonia area showing fossil localities and location of measured sections

4. Measured sections of the Pittsburg Bluff and adjacent formations, Vernonia area

5. Photograph showing contact between siltstone of the Keasey Formation and sandstone of the Pittsburg Bluff Formation -.--- 13

6. Photograph showing siltstone rip-up clasts in Pittsburg Bluff Formation

7. Correlation chart of selected middle Tertiary stratigraphic units in Alaska, Washington, and Oregon

8. Sketch of growth-line sinus on Turritella pittsburgensis, n. sp

\section{TABLES}

TABLE 1. Checklist of species at U.S. Geological Survey localities in the Pittsburg Bluff Formation arranged in approximate stratigraphic order

2. Holocene genera in the Pittsburg Bluff Formation and their preferred bottom sediment and water depth

3. Distribution of molluscan genera in the lower, middle, and upper parts of the Keasey Formation and their occurrence in the Pittsburg Bluff and Eugene Formations

4. Distribution of Pittsburg Bluff species in some other formations of late Eocene, Oligocene, and early Miocene age - .-.-

5. Checklist of Oligocene mollusks in the upper part of the Eugene Formation in Oregon 


\title{
OLIGOCENE MARINE MOLLUSKS FROM THE PITTSBURG BLUFF FORMATION IN OREGON
}

\author{
By Ellen James Moore
}

\begin{abstract}
The first recorded collection of fossils from the Pittsburg Bluff Formation was identified by W. H. Dall in 1896 and was assigned to the Oligocene. This was the first marine fauna on the Pacific coast to be assigned to the Oligocene. Although the fauna was briefly regarded as Eocene in the early 1900's, it has since been referred to the Oligocene, then more precisely to the middle Oligocene, an assignment that still stands.

The Pittsburg Bluff Formation occurs in northwestern Oregon, where fossiliferous exposures are found in streambanks and in cuts on highways, logging roads, and railways. The type area of the formation is along the Nehalem River near Pittsburg, Oreg., where a highway cut affords a good exposure of its lower part. Exposures of the Pittsburg Bluff Formation are relatively scarce; they are interrupted by broad areas of thick soil cover and dense vegetation. The formation is cut by minor visible faults, and there may be others that are not visible, so the mapping is uncertain in some places.

The Pittsburg Bluff Formation conformably overlies the Keasey Formation (late Eocene and early Oligocene) and is conformably overlain by the Scappoose Formation (late Oligocene and early Miocene). Because parts of all these formations are lithologically similar, the stratigraphic position of a nonfossiliferous exposure is sometimes uncertain. New stratigraphic studies indicate, however, that contrary to the opinion of some previous investigators, the Pittsburg Bluff Formation is conformable with the underlying Keasey Formation.

The estimated maximum thickness for the entire formation is 200 $\mathrm{m}$; the thickest continuous measured section of the Pittsburg Bluff Formation is $100 \mathrm{~m}$ thick.

In the present investigation, fossils were collected from newly measured sections. In addition, all the collections from the Pittsburg Bluff Formation on deposit in the U.S. National Museum have been studied, as well as those at the California Academy of Sciences, Stanford University, and the University of California at Berkeley.

A total of 48 species of Oligocene mollusks representing 43 genera and 31 families are described; of these, 5 species and 1 subspecies are new, representing the genera Turritella, Opalia, Cryptonatica, Perse, Nucula, and Felaniella. The biologic affinities of all the species in the formation are reconsidered, and the fauna is correlated with other Oligocene faunas.

The fossil mollusks represent a death assemblage; it seems likely that three habitats may be represented, one of deep water (about $100 \mathrm{~m}$ ), one of moderately shallow water (about $20 \mathrm{~m}$ ), and one of shallow nearshore water, partly intertidal. The remains of mollusks living in these dissimilar habitats were brought together by submarine grain flowage before being fossilized. The bottom sediment was sandy mud. Comparison with ranges of related living genera indicates that the ocean temperature off the northern coast of Oregon, though cooler than it was in the Eocene and Miocene, was perhaps warmer than it is today.
\end{abstract}

\section{INTRODUCTION \\ HISTORY OF INVESTIGATION}

The first description of the rocks in the bluff near Pittsburg was written by J. S. Diller (1896). In his report, Diller assigned the fossil mollusks collected from these rocks to the Oligocene on the basis of identifications made by W. H. Dall. This was the first marine fauna on the Pacific coast to be regarded as Oligocene. In 1903, however, Dall described Callista pittsburgensis from Pittsburg and assigned it to the Eocene. But Clark (1915), after comparing the fossils from this section with other mid-Tertiary taxa of the Pacific coast, some of which had been dated by comparison at the generic level with mollusks in the type sections in Europe and by Lyell's method of percentage of living taxa, reassigned the molluscan fauna from the bluff near Pittsburg to the Oligocene, stating that it was distinct from those of both the Eocene and the Miocene.

The term "Pittsburg Bluffs" was first used for early Oligocene strata of Oregon in a correlation diagram by Hertlein and Crickmay (1925, p. 254), but these men did not formally describe the formation. In 1927 Schenck described what he called the "Pittsburg Bluff sandstone," which he said overlaid the Keasey Shale, was of middle Oligocene age, and could be correlated with the Eugene Formation (early and middle Oligocene), the Tunnel Point Sandstone (middle Oligocene), and the Yaquina Formation (late Oligocene and early Miocene).

In 1936 Schenck (1936, p. 44) defined the Acila shumardi Zone as delimited by the range of Acila shumardi and as being further identified by such forms as Bruclarkia columbiana (Anderson and Martin), Callista pittsburgensis Dall, and Molopophorus gabbi Dall. All are common in the Pittsburg Bluff Formation.

Schenck and Kleinpell (1936) proposed the west coast term "Refugian Stage" for rocks laid down after the Tejon and before the Zemorrian. The Refugian Stage included the Acila shumardi Zone, and its upper part marked the last appearance of Acila shumardi, Callista pittsburgensis, Molopophorus gabbi, and Bruclarkia columbiana. 
Weaver (1937) suggested that the term "Pittsburg Bluff Formation" be applied to the entire middle Oligocene sequence of sedimentary rocks in Columbia County, Oreg., and that the type area of the formation be considered the exposures between Pittsburg and Mist on the Nehalem River in Oregon. In 1942, in a publication on the paleontology of the marine formations of Washington and Oregon, he described and illustrated all of the then known species of mollusks from the Pittsburg Bluff Formation.

Durham (1944) restricted the Pittsburg Bluff fauna to his Molopophorus gabbi Zone. Acila shumardi occurs in both his early and middle Oligocene faunas.

Warren, Grivetti, and Norbisrath (1945) mapped the areal extent of the Pittsburg Bluff Formation in northwestern Oregon and divided the formation into two members. On the basis of the molluscan faunas, they believed the lower member and the lower part of the upper member to belong to the middle Oligocene Molopophorus gabbi zone (as used by Weaver and others, 1944).

In 1946, Warren and Norbisrath described the Pittsburg Bluff Formation as follows:

In the lower part of the Pittsburg Bluff Formation are fine-grained marine sandstones containing numerous fossils in layers along the bedding and in calcareous concretions. These richly fossiliferous sandstones seem to pass upward into coarser massive sandstone which interfingers with cross-bedded, nearshore, marine and brackishwater sandstone. Upward in the formation fossiliferous bands are less common. Toward the top of the formation fossils are few and thick beds of tuffaceous material are prominent.

No subsequent reports dealing primarily with the Pittsburg Bluff Formation have been published; its age, however, has been regarded as provincial middle Oligocene in references to and correlations with the formation since 1946.

\section{PURPOSE AND SCOPE}

The original descriptions of mollusks found in the Pittsburg Bluff Formation are in many papers, none of which deal primarily with the fauna. Many of the original photographs, moreover, are inadequate, and much of the taxonomy is out of date. In this paper all the described mollusks are reillustrated and redescribed, and some needed corrections have been made in their taxonomy. Five new species and a new subspecies, representing six genera, are described and illustrated. Also included are new stratigraphic sections of the Pittsburg Bluff Formation measured in Columbia and Washington Counties, Oreg., near the type area; these are presented together with a geologic sketch map.

The middle Oligocene mollusks found in the Pittsburg Bluff Formation are compared with other known Oligocene faunas of the Pacific coast of North America, and the geologic and geographic ranges of each species are given. Information on the ecology of related modern genera is tabulated, and this data, together with lithologic data, have been used to infer generalities concerning the Oligocene paleoenvironment.

The type locality of Acila (Truncacila) shumardi (Dall) (sec. 23, T. 5 N., R. 4 W., Vernonia quadrangle) is in the type locality of the Pittsburg Bluff Formation. This mollusk lived throughout the Acila shumardi Zone, which has been recognized by various authors at localities ranging from Alaska to California. Schenck (1936, p. 42) proposed the "Acila shumardi biozone" and accepted the definition of a biozone as "a deposit formed during the total existence of a species." He goes on to define the Acila shumardi Zone (1936, p. 44) as being "that group of beds $* * *$ identified by an assemblage of fossils including Acila (Truncacila) shumardi (Dall), Bruclarkia columbiana (Anderson and Martin), Macrocallista pittsburgensis Dall, and Molopophorus gabbi Dall, and limited by the upper and lower range of Acila shumardi." It would seem that he may have had an assemblage zone in mind when he proposed the Acila shumardi biozone. Although $A$. shumardi is especially useful in stratigraphic correlation, its usefulness is enhanced if the entire molluscan assemblage living with it is recognized and understood. This paper seeks to fulfill that purpose.

\section{PREPARATION OF COLLECTIONS}

Each collection of fossils taken from the Pittsburg Bluff area in the 1890's and early 1900's was given a U.S. Geological Survey locality number that designated a geographic position without regard to its stratigraphic interval. This was, of course, the usual practice at the time, but it gave a false impression regarding the taxa that were actually found together in a given lens or layer of rock.

During field investigations conducted in the 1940's for the U.S. Geological Survey, H. E. Vokes collected many fossiliferous slabs from the Pittsburg Bluff Formation to aid in paleoecologic studies. The slabs average perhaps $8 \times 15 \times 20 \mathrm{~cm}$ in overall size; two of them are shown on plate 17 . These slabs, most of them from USGS localities 15264 and 15310, have been individually prepared as part of the present study, and on each specimen taken from a single slab the same letter has been put after the U.S. Geological Survey Cenozoic locality number, for example 15264a, to indicate what fossils were found together in the same slab. In other words, 15264 covers the general locality and 15264a, $15264 \mathrm{~b}$, and so forth, refer to specimens from different slabs from that locality.

Some pieces of rock that could not be prepared by ordinary mechanical means without loss of specimens 
were disintegrated by being soaked in kerosene and then heated in an oven at a temperature of $120^{\circ} \mathrm{C}$. The samples were then washed through a $0.177-\mathrm{mm}$ screen, which retained mollusks of larger diameter and fish remains. Part of the fines from each sample was then washed through a $0.125-\mathrm{mm}$ screen, but the only additional complete organic remains thus recovered were two globigerinid foraminifers.

\section{ABBREVIATIONS}

The following abbreviations are used in this report:

USGS: U.S. Geological Survey, Washington, D. C., Cenozoic locality register.

USGS M: U.S. Geological Survey, Menlo Park, Calif., Cenozoic locality register.

UCMP: California University, Museum of Paleontology, Berkeley, Calif.

CAS: California Academy of Sciences, San Francisco, Calif.

SU: $\quad$ Stanford University, Stanford, Calif.

UW: University of Washington, Seattle, Wash.

UO: $\quad$ University of Oregon, Eugene, Oreg.

ANSP: The Academy of Natural Sciences of Philadelphia, Philadelphia, Pa.

\section{ANNOTATED CHRONOLOGY OF REPORTS DEALING WITH OLIGOCENE FORMATIONS AND FOSSILS, WITH PRIMARY EMPHASIS ON OREGON AND WASHINGTON, 1892-1975}

1892. Dall, W. H., and Harris, G. D.

Assign the Eugene Formation of Oregon [now considered early and middle Oligocene] to the Miocene (p. 227).

1896. Diller, J. S.

Describes and assigns strata on the banks of the Nehalem River at Pittsburg Bluff, Oreg. to the Oligocene on the basis of fossil identifications made by W. H. Dall. None of the names used in Diller's report are currently applied to Pittsburg Bluff mollusks, as they were subsequently recognized as new species and so described. This is the first notice of the occurrence of Oligocene strata in the Pacific Northwest. The report includes a photograph of Pittsburg Bluff (pl. 7, opp. p. 466).

Diller describes the lithology of strata at Pittsburg Bluff as follows: "The upper soft gray sandstone is very fossiliferous in places, and about 30 feet thick. Below are 20 feet of dark shales which weather gray *** Some of the layers of sand are indurated so as to form slabs, thickly set with perfectly preserved

${ }^{1}$ Stratigraphic nomenclature used herein is that of the references cited and is not necessarily in accord with that of the U.S. Geological Survey. My comments are in brackets. fossils." [Diller did not always distinguish between the Keasey Formation, a shale now considered late Eocene and early Oligocene, and the shale that occurs in the Pittsburg Bluff Formation (p. 466).] On the Nehalem River "1 mile beyond Vernonia," he considered the Keasey to be part of the Pittsburg Bluff Formation. But at Wilson's Bluff on the river 3 miles above Vernonia, he does recognize a difference and states, "it is evident the shales above Vernonia are older than those at Pittsburg."

1898. Dall, W. H.

Tentatively assigns the Tunnel Point "beds" of Oregon [middle Oligocene] to the Oligocene (table opp. p. 334).

1903 [1890-1903]. Dall, W. H.

Describes and assigns Callista (Macrocallista) pittsburgensis from the strata at Pittsburg Bluff to the Eocene (p. 1253).

1906. Arnold, Ralph.

Assigns the Tunnel Point "beds" to the Oligocene and correlates them with part of the San Lorenzo Formation [late Eocene to middle Oligocene] of California (p. 10). A list of San Lorenzo Formation fossils is given (p. 17).

1909. Dall, W. H.

Describes two new species, Molopophorus gabbi (p. 45) and Eosiphonalia oregonensis (p. 51), from strata at Pittsburg Bluff, and gives the species, previously identified by Dall as Acila decisa (Conrad), the specific name shumardi (p. 103). Dall regards these fossils as Eocene.

1914. Washburne, C. W.

States (p. 73), in commenting on the fossils collected from beds exposed near Pittsburg that Dall called Eocene and Miocene, that those which Dall called Eocene appear to be higher stratigraphically than those that he called Miocene; he suggests (p. 74) that these fossils may in fact all be Oligocene. The fossil identifications made by Dall are given on page 31 .

1914. Anderson, F. M., and Martin, Bruce.

Describe Agasoma columbiana from the Pittsburg Bluff Formation.

1915. Clark, B. L.

Assigns the fauna at Pittsburg Bluff to the Oligocene and lists the mollusks, comparing them with faunas from the Lincoln [Lincoln Creek] Formation of Washington [late Eocene to early Miocene], and the Oligocene of California.

1916a. Weaver, C. E.

Refers the Oligocene rocks of western Washington to the Clallam Formation [now considered middle Miocene], which he divides into three zones, characterized, in ascending order, by Molopophorus lincolnensis, Turritella porterensis, and Acila gettys- 
burgensis. He calls the rock units containing these zones the Lincoln, Porter, and Blakeley "horizons," respectively. He notes that Acila shumardi and Callista pittsburgensis, two species common in the Pittsburg Bluff Formation, are especially common in the Molopophorus lincolnensis Zone.

1916b. Weaver, C. E.

Assigns mollusk species common in the Pittsburg

Bluff Formation to the Molopophorus lincolnensis

Zone of western Washington (p. 167).

1916c. Weaver, C. E.

Recognizes the Oligocene age (p. 17) of the Gries

Ranch Formation [early Oligocene].

1916d. Weaver, C. E.

Gives the sequence of post-Eocene for western

Washington as follows:

Montesano horizon-Yoldia strigata Zone-upper Miocene

Wahkiakum horizon-Arca montereyana Zonelower Miocene

Blakeley horizon-Acila gettysburgensis ZoneOligocene

Porter horizon-Turritella porterensis ZoneOligocene

Lincoln horizon-Molopophorus lincolnensis Zone-Oligocene

[The Molopophorus lincolnensis and Turritella porterensis Zones contain mollusks that occur in the Pittsburg Bluff Formation.]

1916e. Weaver, C. E.

Gives a faunal list for the Acila gettysburgensis Zone, which he assigns to the late Oligocene.

1917. Dickerson, R. E.

Describes 35 new species from the vicinity of the Grecco Ranch House, 4 miles east of Vader, Wash. [Gries Ranch Formation, early Oligocene]. He regards this fauna as being littoral, of early Oligocene age, and subtropical; and he believes it to be a lower facies of Weaver's Molopophorus lincolnensis Zone.

1918. Clark, B. L., and Arnold, Ralph

Assign the Oligocene marine rocks of western Washington to the San Lorenzo Group and include Weaver's Lincoln, Porter, and Blakeley horizons and also the Sooke Formation of Vancouver Island ( $p$. 298). They believe the Oligocene of Oregon and Washington was deposited in geosynclinal depressions partly enclosed by land; one of these was probably a large trough between the Cascades and the Olympics. They recognize three faunas in Washington; these are, in decreasing order of age, the Agasoma acuminatum beds, the Molopophorus lincolnensis Zone, and the Acila gettysburgensis Zone. They believe the differences between the lower two faunas to be related to temperature.
1918. Van Winkle, K. E.

Divides the Porter beds of southwestern Washington into an upper part that she calls the Turritella porterensis Zone, and a lower part [Gries Ranch Formation] that she calls the Barbatia merriami Zone. She regards Lincoln Creek "beds" as equivalent to the Molopophorus lincolnensis Zone and to the middle part of the Porter beds.

1918. Clark, B. L.

Reports that Acila shumardi and Callista pittsburgensis, species common in the Pittsburg Bluff Formation, occur in the Kirker Tuff [Oligocene] of California and assigns the Pittsburg Bluff locality to the lower Oligocene (footnote 18, p. 59). He records the occurrence of Callista pittsburgensis Dall and Nuculana lincolnensis (Weaver) in the Kreyenhagen Shale of California [Eocene and Oligocene], which he assigns to the San Lorenzo Series (p. 63).

Because certain species that occur in either the Molopophorus lincolnensis or the Acila gettysburgensis Zones occur together in the San Lorenzo in the Mount Diablo area, he does not believe that these zones represent distinct geologic horizons.

His paper includes a comprehensive historical summary of the literature on the marine Oligocene of the Pacific coast (p. 57-72).

1919. Smith, J. P.

Points out that the Oligocene has fewer tropical genera than the Eocene and believes that although Oligocene faunas were already provincial, climatic zones had not yet been definitely established. $\mathrm{He}$ regards the Oligocene as oriental in its affinities, but considers both the Astoria [Miocene] and the San Lorenzo [late Eocene to middle Oligocene] Formations as Oligocene.

1921. Clark, B. L.

Places all the Oligocene in the San Lorenzo, which he divides into two parts, on his correlation chart-a generalized section for Oregon, Washington, and northern California. He notes the occurrence of the typical Pittsburg Bluff species Acila shumardi and Callista pittsburgensis in the lower part of the San Lorenzo which he calls the "Molopophorus lincolnensis Zone". He correlates this zone with the Kreyenhagen Shale of California and the Vicksburg Group of the southeastern United States (table opp. p. 586). He divides the Oligocene of the west coast into two subepochs; these subepochs are represented by the Molopophorus lincolnensis and Acila gettysburgensis Zones which are equivalent to the Lincoln and San Lorenzo Formations (p. 591-592).

1923. Wagner, C. M., and Schilling, K. H.

Correlate the San Emigdio [late Eocene and Oligocene] and Pleito [Oligocene] Formations of 
California with the Pittsburg Bluff Formation and give a list of fossils for the Pittsburg Bluff Formation. 1925. Clark, B. L.

Describes two new species, Tellina pittsburgensis and Spisula pittsburgensis, from the type area of the Pittsburg Bluff Formation.

1925. Hertlein, L. G., and Crickmay, C. H.

First recognize the rocks exposed at Pittsburg Bluff as a stratigraphic unit and first call them the "Pittsburg Bluffs." They believe these rocks to be of undoubted Oligocene age, possibly early Oligocene, and possibly equivalent to those exposed in San Emigdio Canyon, California (p. 254).

1927. Schenck, H. G.

Correlates the Yaquina Formation [late Oligocene and early Miocene], the Eugene Formation [early and middle Oligocene], and the Tunnel Point Sandstone [middle Oligocene], at least in part, on the basis of faunal evidence and reports that diagnostic species in each of these formations also occur in the Pittsburg Bluff Formation, which he assigns to the middle Oligocene.

1928. Cushman, J. A., and Schenck, H. G.

Tentatively regard the Bastendorf [Bastendorff] Shale and Keasey Formation as lower Oligocene; these formations are said to be of the same age and similar facies and to contain certain distinctive species of foraminifers.

1928. Schenck, H. G.

Describes the Pittsburg Bluff Formation, cites some of its molluscan fossils, and correlates it with the Eugene Formation [early and middle Oligocene], the Tunnel Point Formation [middle Oligocene], and the Yaquina Formation [late Oligocene and early Miocene]. He lists mollusks from the Eugene Formation, which in his opinion is equivalent to at least a part of the Molopophorus lincolnensis Zone of Washington.

1929. Schenck, H. G.

Gives evidence that the Pittsburg Bluff Formation is younger than the Tejon Formation [Eocene] and older than the Nye Shale [early Miocene] and that it probably represents the Lincoln-Porter horizon of Washington. He notes that some of the diagnostic species occurring in the Pittsburg Bluff Formation also occur between rocks of Tejon and Vaqueros [Eocene and Miocene] age in California.

1929. Clark, B. L.

Divides the Oligocene into three "faunal horizons." In Washington, he recognizes three horizons, in decreasing order of age, the Gries Ranch, Lincoln, and Restoration Point, but in California he recognizes only two horizons which he calls the Lincoln and San Ramon. He finds the following typical Pittsburg Bluff species in the "Lincoln horizon" of the San Emigdio Mountains of California: Acila shumardi, Callista pittsburgensis, and Bruclarkia columbiana (p. 18). 1932. Clark, B. L.

Believes the fauna of the Poul Creek [middle Oligocene to early Miocene] and Yakataga Formations [middle Miocene to early Pleistocene] of Alaska is the same and belongs to one zone-the Blakeley horizon of Washington. He regards the Blakeley horizon as late Oligocene and correlates it with the San Ramon Formation of California and the Sooke Formation of Vancouver Island.

1936. Schenck, H. G.

Correlates the Pittsburg Bluff Formation in part with the San Emigdio Formation [late Eocene and Oligocene] of California, and in part with the Lincoln [Lincoln Creek] Formation [late Eocene to early Miocene] of Washington (p. 65).

He gives the name Acila shumardi Zone to a unit delimited by the range of Acila shumardi (Dall) (p. 44). This unit is said to be about 3,000 feet thick in Columbia County, Oreg. Among its other diagnostic species are Bruclarkia columbiana (Anderson and Martin), Callista pittsburgensis Dall, and Molopophorus gabbi Dall.

1936. Schenck, H. G., and Kleinpell, R. M.

Propose the name Refugian Stage for rocks laid down after the Tejon Stage (restricted) and before the Zemorrian Stage. This stage includes the Eugene [early and middle Oligocene], Pittsburg Bluff [middle Oligocene], Tunnel Point [middle Oligocene], Keasey [late Eocene and early Oligocene], and Bastendorf [Bastendorff] [late Eocene and early Oligocene] Formations of Oregon, together with the Lincoln [Lincoln Creek] Formation [middle Oligocene] and the Gries Ranch Formation [early Oligocene] of Washington. The Refugian Stage includes the Acila shumardi Zone. The upper part of the Refugian Stage is marked by the last occurrence of Acila shumardi, Callista pittsburgensis, Molopophorus gabbi, and Bruclarkia columbiana, all of which are common in the Pittsburg Bluff Formation.

1937. Weaver, C. E.

Suggests that the term Pittsburg Bluff Formation be applied to the entire middle Oligocene sequence of sedimentary rocks in Columbia County, Oreg. and that the type area be considered the exposures between Pittsburg and Mist on the Nehalem River, Oreg. (p. 113). He states that fossils are scattered throughout the Pittsburg Bluff Formation but are especially abundant in lenses 2 to 6 inches thick, where they are so compacted as to form calcareous nodules ( $\mathrm{p}$. 171).

1937. Clark, H. L.

Reports that a fossil sea urchin has been found in 
the waste from a well dug in sec. 12 , T. 3 N., R. 4 W., that it is supposed to have come from the Pittsburg Bluff Formation. [Recent mapping done in connection with my report shows that it probably came from the Scappoose Formation of late Oligocene and early Miocene age.]

1938. Effinger, W. L.

Correlates the Gries Ranch Formation with the Keasey Formation and the lower part of the Pittsburg Bluff Formation, both of which he believes to be early Oligocene (fig. 3, p. 359). He regards the Gries Ranch fauna as subtropical and believes it to represent a nearshore or littoral facies (p. 360).

1938. Clark, B. L., and Anderson, C. A.

Show the Pittsburg Bluff and Eugene Formations as "lower Oligocene" on a correlation chart and correlate them with the Lincoln [Lincoln Creek] Formation of southwestern Washington and the San Lorenzo Group of California. They correlate the Wheatland Formation with the Keasey and Bastendorf [Bastendorff] Formations in Oregon and the Gries Ranch Formation in Washington and consider them to be of late Eocene or early Oligocene age ( $p$. 944).

1938. Kleinpell, R. M.

Assigns the type Lincoln [Lincoln Creek] Formation of Washington and the Eugene, Pittsburg Bluff, and Tunnel Point Formations of Oregon to the upper Refugian. He regards the Bastendorf [Bastendorff] Shale and Keasey Formation of Oregon as lower Refugian and believes that the Gries Ranch Formation of Washington also is probably lower Refugian.

He notes that the molluscan assemblages of the Acila shumardi Zone of Schenck are definitely associated with upper Refugian foraminifers. These foraminifers are believed to have lived in deeper water, or at least cooler water, than those of the lower Refugian Turritella variata Zone of California (p. 152).

To Kleinpell the foraminifers of the Refugian Stage suggest a cool-water habitat near the edge of the continental shelf, but not necessarily in a boreal province. Foraminifers characteristic of shallower water are numerous only locally, and there is a notable decrease of the open-sea types so abundant in the late Eocene. Southern foraminifers are scarcer on the whole than in the two directly overlying stages, suggesting that the climate was somewhat cooler in the middle Oligocene.

1942. Weaver, C. E.

Describes and illustrates all the known species of mollusks from the Pittsburg Bluff Formation and includes a checklist of all the species known to occur in the Tertiary formations of Oregon and Washington.
1943. Forrest, L. C.

Includes a chart of Oligocene formations in California and compares current age assignments with former age assignments (pl. 3).

1943. Hanna, G. D., and Hertlein, L. G.

Note the occurrence of Callista pittsburgensis in the Kreyenhagen Shale [Eocene and Oligocene] in California.

1944. Zimmerman, John, Jr.

Regards the Tumey Sandstone, exposed in Fresno County, Calif., as late Eocene and early Oligocene, but believes that if the Acila shumardi zone is upper Refugian, the Tumey faunule is also. He correlates the Tumey with at least a part of the San Emigdio Formation, which also contains Acila shumardi. He notes that the Tumey Sandstone contains several mollusks characteristic of the Pittsburg Bluff Formation.

1944. Allen, J. E., and Baldwin, E. M.

Consider the Bastendorf [Bastendorff] Shale mostly latest Eocene but possibly in part early Oligocene. They report it consists predominantly of shale and is 2,095 feet thick.

They note that the Tunnel Point Sandstone is middle Oligocene, overlies the Bastendorf [Bastendorff] Shale with apparent conformity, consists mainly of sandstone, and is 800 feet thick.

1944. Durham, J. W.

Reports the occurrence of Acila shumardi in the Molopophorus stephensoni, M. gabbi, Turritella olympicensis, and $T$. porterensis Zones, which collectively make up the Gries Ranch, Pittsburg Bluff, and Lincoln [Lincoln Creek] Formations. He states that the Pittsburg Bluff fauna is restricted to the Molopophorus gabbi Zone and is characterized by Bruclarkia columbiana, Molopophorus dalli, Perse olympicensis quimpersensis, $P$. pittsburgensis, and Mactra pittsburgensis.

1944. Keen, A. M., and Bentson, Herdis

Show that a marked decrease in the total number of Tertiary molluscan species occurred in California during the Oligocene (fig. 3, p. 8).

1945. Warren, W. C., Grivetti, R. M., and Norbisrath, Hans

Report the Pittsburg Bluff Formation to be disconformably underlain by the Keasey Shale [late Eocene and early Oligocene] and disconformably overlain by beds of Blakeley age [late Oligocene or early Miocene]. The basal member of the Pittsburg Bluff Formation is a moderately indurated, massive, quartzose sandstone, marine at the type locality, but terrestrial on Pebble Creek. This basal member is at least 500 feet thick. It is overlain by a massive to poorly stratified, sandy tuffaceous shale member 
which includes numerous ash beds that are mostly less than 1 foot thick. The thickness of the Pittsburg Bluff Formation along the United Railway is about 850 feet.

Fossils at the type locality (USGS 15264) occur in the sandstone member and belong to the Molopophorus gabbi Zone, but the upper part of the shale member may belong to a slightly younger zone. The authors list 40 species of mollusks, identified by $\mathrm{H}$. E. Vokes.

1946. Warren, W. C., and Norbisrath, Hans

Describe the lower part of the Pittsburg Bluff Formation as composed of fine-grained marine sandstone containing numerous fossils in layers along the bedding and in calcareous concretions. These beds apparently pass upward into coarser massive sandstone which interfingers with crossbedded, nearshore, marine, and brackish-water sandstone. Higher in the section there are fewer molluscan fossils and more brackish-water beds containing plant remains. Near the top there are few fossils and many thick beds of tuffaceous material. The type locality, on the Nehalem River Highway near Pittsburg, displays marine fossiliferous beds and is near the base of the formation. The formation as a whole is characterized by a nearshore megafauna that is rich in the number of individuals of certain species. Representative mollusks are listed (p. 230).

The rocks disconformably overlying the Pittsburg Bluff Formation are named the Scappoose Formation [late Oligocene and early Miocene] (p. 231).

The authors regard the fauna of the Pittsburg Bluff Formation as similar to that of the Molopophorus gabbi Zone of Durham (1944, p. 112), but believe that the middle part of the Quimper Sandstone and the beds at Clatskanie, Oreg., correlated by Durham with the Pittsburg Bluff, are equivalent to the Gries Ranch Formation and therefore older.

1946. Detling, M. R.

Believes that the Bastendorf [Bastendorff] Shale is either Eocene or Oligocene and that it may have been deposited in warm or temperate shallow water near the shoreline.

1947. Lowry, W. D.

States that the shoreline of the Oligocene sea in northwestern Oregon almost paralleled the present coastline and was east of Eugene, Albany, and Silverton and west of Portland, Oreg. (p. 3).

Believes that the coal that occurs in the Pittsburg Bluff Formation 21/2 miles west of Scappoose and 1 mile south of Deer Island, Oreg., indicates the shoreline was nearby (p. 6).

1948. Vokes, H. E., and Snavely, P. D., Jr.

Report that in the Eugene area the earliest middle
Oligocene sediments were deposited in a restricted seaway north of the Eugene quadrangle. The continental deposits of the Fisher Formation had been laid down throughout this area, and the sea advanced over them toward the south. In the transgressing sea, the Eugene Formation was deposited in shallow offshore water.

1948. Rau, W. W.

Believes that all or part of the Porter Shale of northwestern Washington may be late Eocene, and possibly none of it of middle Oligocene age (p. 157). Reports that five species of foraminifers, and 20 closely related forms found in the Porter Shale, also occur in the Tumey Formation [early and middle Oligocene], and that one foraminifer has also been found in the Keasey Formation [late Eocene and early Oligocene].

The Porter Shale was deposited offshore in a fairly shallow, temperate to warm sea.

1952. Durham, J. W.

Finds that the Stepof Bay fauna [Oligocene] of Alaska has subtropical or warm-temperate affinities. 1953. Moore, R. C., and Vokes, H. E.

Briefly consider in discussing the age of the Keasey Formation, the Pittsburg Bluff Formation, and compare the mollusks occurring in the crinoidbearing beds of the Keasey with those in the Pittsburg Bluff Formation. They show part of the Pittsburg Bluff Formation on an outcrop map of the area in which the crinoid beds occur. They report that the Keasey Formation includes the latest Eocene and early Oligocene and that the crinoid-bearing beds are probably early Oligocene.

They believe that the Keasey Formation was deposited in relatively deep water, below effective wave action, but near the shoreline. The crinoid-bearing middle member of the Keasey was deposited in water ranging to a depth greater than 500 fathoms [914 m]. 1953. Weaver, C. E.

States that the Refugian is coeval with the "Keasey," "Lincoln," and "Blakeley" Stages, in ascending order. He regards the San Ramon Formation [early Miocene (?) ] as Oligocene and correlates it with the "Blakeley" Stage.

1956. Stewart, R. E.

Considers the Toledo Formation of western Oregon late Eocene to middle Oligocene in age and assigns the Moody Shale Member to the late Eocene. He regards the Bastendorf [Bastendorff] Shale of southwestern Oregon as late Eocene and early Oligocene; the upper 700 feet are Oligocene (p. 59).

1958. Brown, R. D., Jr., and Gower, H. D.

Divide the Twin River Formation of Arnold and Hannibal (1913) in northwestern Washington into 
three members, which they believe, on the basis of fossil mollusks, foraminifers, and plant leaves, to be late Eocene to early Miocene (p. 2510). They correlate the Lincoln [Lincoln Creek] Formation of Weaver with the middle and upper members of the Twin River Formation.

1960. Kanno, Saburo

States that the mollusks Cyclocardia (Cyclocardia) hannibali and Lucinoma columbiana, which occur in the Pittsburg Bluff Formation, also occur in the Ushikubitoge Formation [Oligocene] of central Japan.

1961. MacNeil, F. S., Wolfe, J. A., Miller, D. J., and Hopkins, D. M.

Show the Acila shumardi Zone as middle and late Oligocene, the Stepovak Series as early and middle Oligocene, and the Poul Creek Formation as middle Oligocene to early Miocene (on a correlation chart of Tertiary formations exposed in Alaska).

They state that some stocks of the mollusks were of Asiatic origin and occur in older rocks in Alaska than in Oregon and California.

1963. Snavely, P. D., Jr., and Wagner, H. C.

Describe marine Oligocene rocks of western Oregon and Washington as consisting of massive tuffaceous siltstone and fine-grained sandstone with intercalated beds of pumiceous lapilli, tuff, and glauconite (p. 16). They include a paleogeologic map showing the Oligocene coastline (fig. 13, p. 15).

1964. Brabb, E. C.

Subdivides the San Lorenzo Formation of the central California Coast Ranges into the Two Bar Shale Member [late Eocene] and the Rices Mudstone Member [late Eocene and Oligocene]. The foraminifers Uvigerina cocoaensis, "Planulina" haydoni, and Cibicides hodgei (p. 677) occur in the lower part of the Rices Mudstone Member. [These species are present in the Bastendorff Shale.] The type section of the Rices Mudstone Member contains the Pittsburg Bluff mollusks Litorhadia washingtonensis and Nemocardium lorenzanum (p. 677).

He reports that many or all of the mollusks found by Arnold (1908) in the San Lorenzo Formation occur in the upper part of the Rices Mudstone Member or the Vaqueros Sandstone (p. 675).

1964. Zullo, V. A., Kaar, R. F., Durham, J. W., and Allison, E. C.

List the occurrence of 36 taxa, representing 7 phyla, in the Keasey Formation, which they believe to have been deposited in water about 200 fathoms $(350 \mathrm{~m})$ deep. They believe the undisturbed echinoids indicate either rapid live burial or a scarcity of scavengers and detritus feeders.

1965. Burke, C. A.
Reports that collections of Oligocene fossils from the Alaska Peninsula are characterized by Acila shumardi and resemble those of the Lincoln Creek Formation in Washington (p. 113-114).

1965. MacNeil, F. S.

Believes the Oligocene faunas of Alaska are predominantly of Asiatic origin and many Asiatic species appeared earlier in Alaska than in Oregon or California.

[Mollusks that occur in the Pittsburg Bluff Formation are found in the Stepovak Formation, early and middle Oligocene.]

1966. Oakeshott, G. B.

Considers, on a correlation chart (fig. 3, opp. p. 36), the following marine formations of the California Coast Ranges to be at least in part middle Oligocene: Tumey Formation, "Kirker" Sandstone, San Ramon, San Lorenzo, and Alegria Formations.

1966. Dibblee, T. W., Jr.

Reports that the Alegria Formation near Santa Barbara, Calif., contains Callista sp. cf. C. pittsburgensis and Acila shumardi, species that occur in the Pittsburg Bluff Formation. The entire fauna indicates an Oligocene (Refugian) age, as does the fauna from the Gaviota Formation.

1967. Wolfe, J. A., and Hopkins, D. M.

State that a sharp cooling took place during the middle Oligocene (p. 72, fig. 3), and that radiometric dates indicate this cooling took place within an interval no longer than 2 million years and possibly as short as 1 million years.

1967. DeLise, K. C.

Lists the following Pittsburg Bluff mollusk species as occurring in the upper sandstone unit of the San Emigdio Formation of California (p. 16): Acila shumardi, Bruclarkia columbianum?, and Polinices washingtonensis. [Also cites Molopophorus dalli, a species that seems in Oregon to be restricted to the early Oligocene.]

1969. Hickman, C. J. S.

Describes two new species that occur in both the Pittsburg Bluff Formation and the Eugene Formation [early and middle Oligocene]: Tellina aduncanasa and Neverita thomsonae. Seventeen species common to both the Eugene and Pittsburg Bluff Formations are described.

She states that the Eugene Formation is early and middle Oligocene and contains a fauna of mixed Keasey and Pittsburg Bluff affinities.

1969. Denton, G. H., and Armstrong, R. L.

State that the Poul Creek Formation in southern Alaska is of late Oligocene or early Miocene age, is $1,875 \mathrm{~m}$ thick, and consists of marine sediments deposited in a temperate or subtropical climate (p. 1137). 
1969. Fairchild, W. W., Wesendunk, P. R., and Weaver, D. W.

Report a slight cooling throughout the area of the present California Coast Range during the time that the San Lorenzo Formation, of late Eocene to middle Oligocene age, was being deposited.

1969. Snavely, P. D., Jr., MacLeod, N. S., and Rau, W. W.

Refer the Oligocene siltstone of the Newport area, Oreg., informally called "siltstone of Alsea" and previously included in the upper Toledo Formation, to the upper Refugian and the Zemorrian Stages. [Mollusks indicate a middle Oligocene to late Oligocene or early Miocene age for this unit.]

1970b. Addicott, W. O.

Considers the Oligocene "Lincoln Stage" equivalent to the biozone of Acila shumardi, which is assigned to the Refugian Stage. He believes less than 10 percent of the still-living genera from the Acila shumardi Zone of the San Emigdio Mountains, Calif., are tropical or subtropical.

He believes the mollusks of the lower part of the "Lincoln Stage" are marginally subtropical to warm temperate.

He reports that more than half of the molluscan genera from the lower part of the "Lincoln Stage" today range northward into the temperate Oregonian molluscan province. He believes the late Oligocene Echinophoria rex Zone of Durham (1944) was probably warm temperate.

He believes that the decreases in warm-water genera and taxonomic diversity show cooling during the middle Oligocene.

1971. MacNeil, F. S.

Reports that species of mollusks and closely related forms found in the Pittsburg Bluff Formation are found in the Poul Creek Formation [middle Oligocene to early Miocene].

1972. Berggren, W. A.

Considers the Refugian Stage late Eocene and the Zemorrian Stage Oligocene.

1972. McKeel, D. R., and Lipps, J. H.

Believe planktonic foraminifers and coccoliths from the middle part of the siltstone of Alsea, exposed along the north side of Alsea Bay, near Newport, Oreg., suggest a latest Eocene or earliest Oligocene age for this unit.

1973. Addicott, W. O.

Reports that Bruclarkia columbiana (Anderson and Martin), a Pittsburg Bluff species, occurs in the Cymric Shale Member [Oligocene] of the Temblor Formation in California. Neverita thomsonae Hickman, Panopea ramonensis (Clark), and Dentalium laneensis Hickman, also Pittsburg Bluff species, occur in the Wygal Sandstone Member [Oligocene] of the Temblor Formation.

He notes that Bruclarkia columbiana is restricted to the upper part of the Refugian Stage in California but is found in the middle and upper part in western Washington, which is equivalent to the Acila shumardi Zone and the "Lincoln Stage." He states that beds containing Bruclarkia columbiana can be traced into the lowermost part of Kleinpell's type Zemorrian section suggesting that the Refugian and Zemorrian Stages are in part coeval.

1973. Jeletzky, J. A.

Recognizes the post-late Eocene regional molluscan stages-Keasey (in part), Lincoln, Blakeley, and Clallam - of the Pacific northwest from southeastern Alaska to southwestern Oregon. Within this northern region of the Pacific coast, these zones persist through intertidal pebble conglomerate, grit, and sandstone to outer neritic or bathyal siltstone and shale. The southern molluscan faunas of the Pacific coast served as a basis for another regional sequence of molluscan stages-Lorenzian, Vaquerosian, Temblorian, Montereyan, and Margaritan. He suggests that the post-late Eocene molluscan and foraminiferal faunas of western North America were controlled by water temperature.

He believes that the northern set of Tertiary molluscan stages and zones, when used within the northern region, are equal or superior to the regional foraminiferal zones and stages.

He correlates the Lincoln molluscan stage of the northern Pacific coast with the upper Refugian foraminiferal stage, and places part or all of the Keasey molluscan stage of the northern region in the uppermost Eocene.

1974. Watkins, Rodney

Names four communities of mega-invertebrates in the Kreyenhagen Formation [Eocene and Oligocene] in the Arroyo Ciervo area, Calif., that he considers mappable ecologic units. Two are named for characteristic Pittsburg Bluff species, the "Macrocallista pittsburgensis Community," which consists largely of $M$. pittsburgensis, and the "Nuculana washingtonensis Community," which consists almost entirely of $N$. washingtonensis and associated $M$. pittsburgensis. The Pittsburg Bluff Formation of Oregon is in a "Northern Province" with 17 or less percent of warm-water genera. The fauna probably lived in a littoral or very shallow sublittoral environment. Macrocallista pittsburgensis is eurytropic and maintains large populations in several environments.

1975. Snavely, P. D., Jr., MacLeod, N.S., Rau, W. W., Addicott, W. O., Pearl, J. E., and Quinterno, P. J. 
Name and describe the Alsea Formation [early to late Oligocene], exposed along the shore of Alsea Bay, Oreg., and correlate it with the Eugene and Pittsburg Bluff Formations and the upper part of the Keasey Formation in Oregon, and with the Lincoln Creek and Blakeley Formations and the middle and upper members of the Twin River Formation in Washington.

\section{ACKNOWLEDGMENTS}

I am indebted to my colleagues Warren O. Addicott, U.S. Geological Survey; W. P. Woodring, U.S. National Museum; F. Stearns MacNeil, Fort Myers, Fla.; Arnold Ross and George E. Radwin, San Diego Natural History Museum, for helpful discussions, advice, and assistance. The late Leo G. Hertlein, California Academy of Sciences, provided me with type specimens and information pertinent to them and was helpful in many other matters. Joseph H. Peck, University of California, and Horace G. Richards, Academy of Natural Sciences of Philadelphia, kindly made available to me type fossils that I needed. To Kenji Sakamoto, U.S. Geological Survey, I am especially indebted for his patience and care in taking the photographs that illustrate this report.

The San Diego Natural History Museum kindly made office space available to me, and Mrs. Azalea Gorby, Librarian, obtained needed references. Anthony D'Attilio graciously agreed to draw the suture sketch of Turritella pittsburgensis, $\mathrm{n}$. sp. To the entire staff of the museum I would like to extend my thanks for their kindness and willingness to offer assistance when needed.

Kenneth W. Ciriacks, Amoco Production Co., Tulsa, Okla., provided me with information relating to the occurrence of Pittsburg Bluff species in Alaska. The release of this information was granted by Amoco Production Co., Denver Division, Colo.

The Crown Zellerbach Corp., Vernonia, Oreg., kindly made available a map of the corporation's tree farm.

I am indebted to the late Frank C. Calkins, formerly a geologist in the U.S. Geological Survey, who at the age of 95 increased the readability of the nontechnical parts of my manuscript.

\section{PITTSBURG BLUFF FORMATION STRATIGRAPHY}

\section{GENERAL FEATURES AND GEOGRAPHIC DISTRIBUTION}

The Pittsburg Bluff Formation is confined to northwestern Oregon (figs. 1-3). Most of its exposures are in the Vernonia 15-minute quadrangle and in the northwestern quarter of the Forest Grove 15-minute quadrangle, but a few exposures of it, containing fossils, are found in the Cathlamet and Svenson 15-minute quadrangles. The formation is characterized by gentle

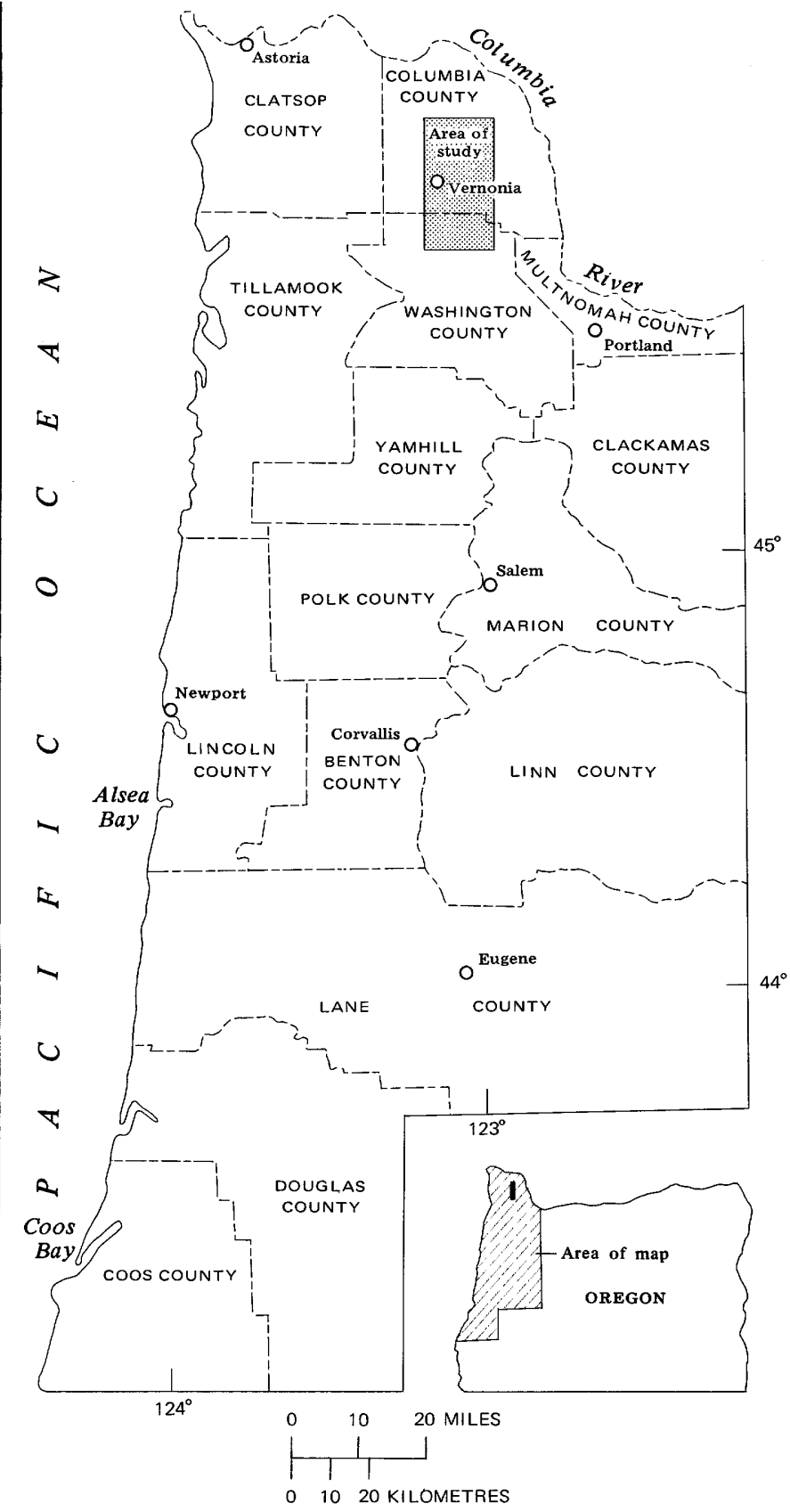

FIGURE 1.-Location of area of study at Vernonia, Oreg.

northwest-trending folds superimposed on an eastward regional dip of about $5^{\circ}$. It is underlain by the Keasey Formation (late Eocene and early Oligocene) and overlain by the Scappoose Formation (late Oligocene and early Miocene) (fig. 4).

The precise stratigraphic assignment of some fossil localities within the Pittsburg Bluff Formation is uncertain owing to discontinuity in outcrops. Local structure compounds the stratigraphic uncertainty. Southeastward from the type locality, for example, many of the richest collections, all of approximately the same 


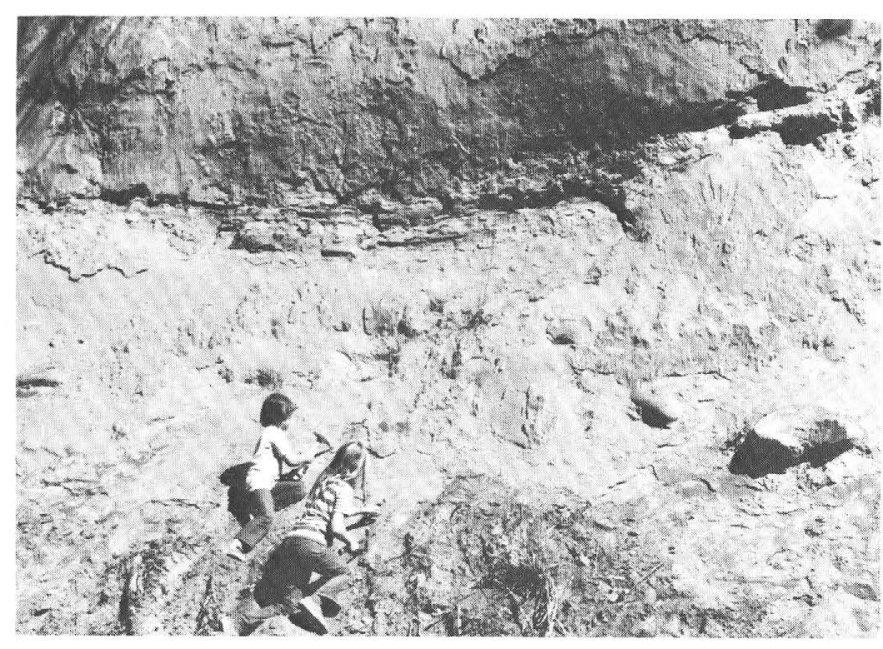

FIGURE 2.-Type locality of Pittsburg Bluff Formation $1 \mathrm{~km}$ northeast of Pittsburg, Oreg. The calcite-cemented concretions are aligned with a bed rich in molluscan fossils. Trough-shaped sedimentary structure (at top) may have formed when sand slid downward on submarine slope.

age, were taken at widely separated localities in a long anticlinal valley drained by the East Fork of the Nehalem River.

\section{TYPE LOCALITY}

The type locality, which exposes the lower part of the Pittsburg Bluff Formation, but not quite the base, is a roadcut on Oregon State Highway 47,1 km northeast of Pittsburg, where the exposed section is about $10 \mathrm{~m}$ thick. The typical sequence in this cut consists of a 2 -m-thick layer of sandstone showing prominent bioturbation overlain by a 10 -cm-thick fossiliferous limy layer or a layer of concretions. These are overlain by a laminated sandstone with laminae about $5 \mathrm{~mm}$ thick, which becomes bioturbate $1 \mathrm{~m}$ above its base. The entire section is highly fossiliferous, but shells are most abundant in the limy layers.

TYPE AREA

The type area of the Pittsburg Formation extends along the Nehalem River between Pittsburg and Mist, Oreg. The Pittsburg Bluff Formation is about $200 \mathrm{~m}$ thick. The olive-gray siltstone of the Keasey Formation (late Eocene and early Oligocene) is conformably overlain by $30 \mathrm{~m}$ of massive olive-gray fine-grained sandstone (fig. 5). The sandstone is characterized by fossiliferous concretions (fig. 2), by trough-shaped prisms possibly resulting from internal shear during aggradation, and locally by siltstone rip-up clasts (fig. 6). Thin-bedded light-olive-gray fine-grained sandstone and siltstone with foreset beds and local coal beds near the top occupy the next $70 \mathrm{~m}$ (fig. 4). The uppermost 100 $\mathrm{m}$ consists of massive friable olive-gray fine-grained sandstone. The Pittsburg Bluff Formation is overlain by dusky-yellow fine-grained tuffaceous sandstone of the Scappoose Formation. Locally the contact is marked by a cobble conglomerate.

A faunal break occurs approximately in the middle of the Pittsburg Bluff Formation. This break possibly may be only an apparent one, and may merely reflect the facts that the lower part of the formation is generally more fossiliferous than the upper parts and that it includes the easily accessible classic exposure on State Highway 47. Nonetheless, a difference in the molluscan fauna exists and may reflect a real change in the composition of the Pittsburg Bluff fauna. At one locality, USGS 15588, at the base of the upper part of the formation, species elsewhere confined to the upper or lower parts occur together.

The following mollusks occur only in the lower $100 \mathrm{~m}$ of the Pittsburg Bluff Formation (excluding USGS locality 15588).

\section{Gastropods}

Opalia (Dentiscala?) hertleini, n. sp.

Crepidula pileum (Gabb)

Polinices washingtonensis (Weaver)

Sinum aff. S. obliquum (Gabb)

Priscofusus stewarti (Tegland)

Perse pittsburgensis vernoniensis, $\mathrm{n}$. subsp.

Taranis columbiana (Anderson and Martin)

Spirotropis kincaidi (Weaver)

Odostomia winlockiana Effinger

Pelecypod

Crenella porterensis Weaver

The following mollusks occur only in the upper $100 \mathrm{~m}$ of the Pittsburg Bluff Formation (excluding USGS locality 15588).

Gastropods

Architectonica blanda Dall

Aforia campbelli Durham

Pelecypods

Cyclocardia (Cyclocardia) cf. C. hannibali (Clark)

Spisula (Mactromeris?) veneriformis Clark

The following mollusks occur throughout the entire thickness of the Pittsburg Bluff Formation.

Gastropods

Turritella pittsburgensis, n.sp.

Cryptonatica pittsburgensis, n. sp.

Neverita (Glossaulax) thomsonae Hickman

Eosiphonalia oregonensis (Dall)

Bruclarkia columbiana (Anderson and Martin)

Molopophorus gabbi Dall

Perse pittsburgensis Durham

Suavodrillia winlockensis (Effinger)

Acteon chehalisensis (Weaver)

Scaphander stewarti Durham 


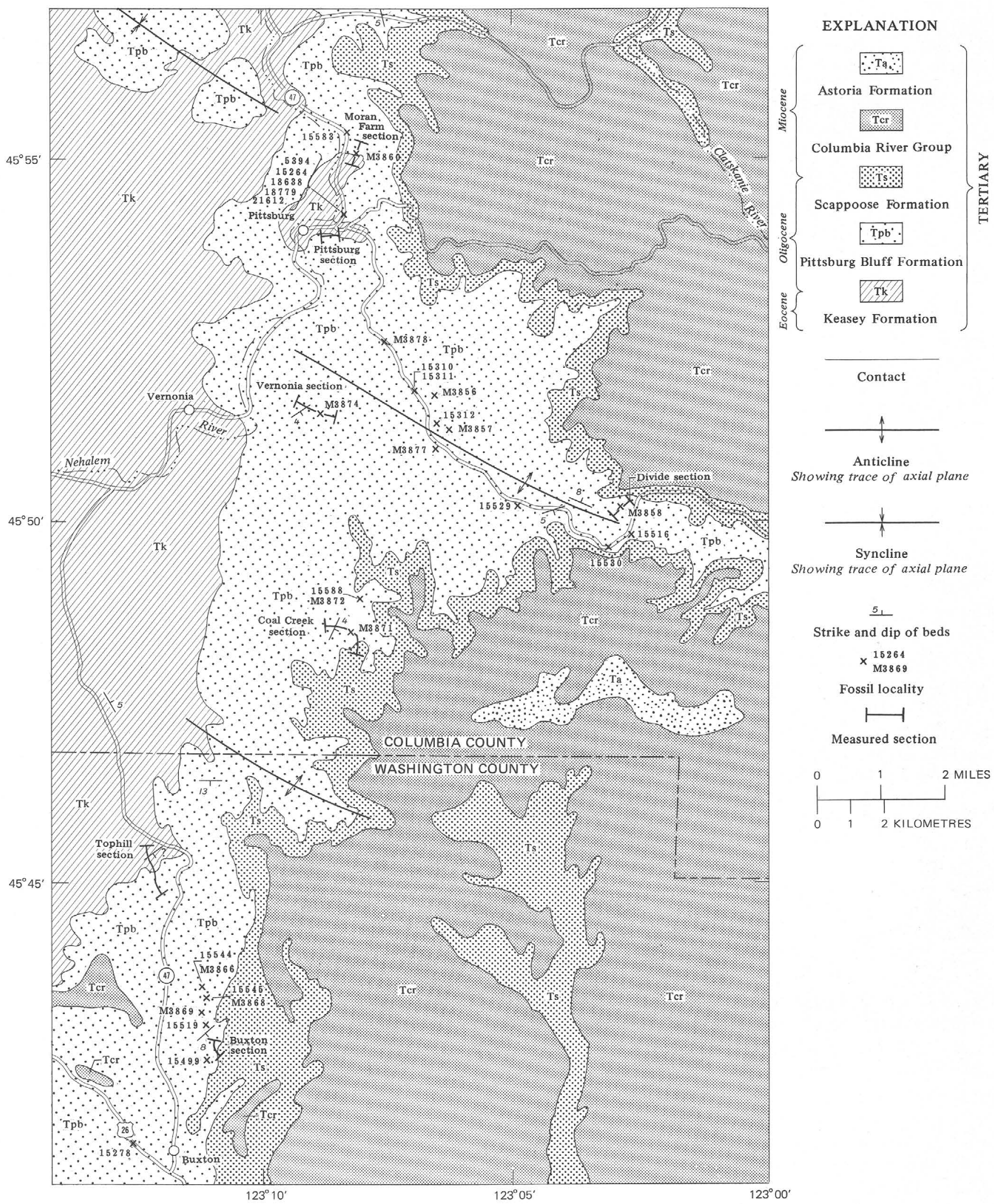

FIGURE 3.-Geologic sketch map of the Vernonia area, northwestern Oregon, showing fossil localities and location of measured sections. 


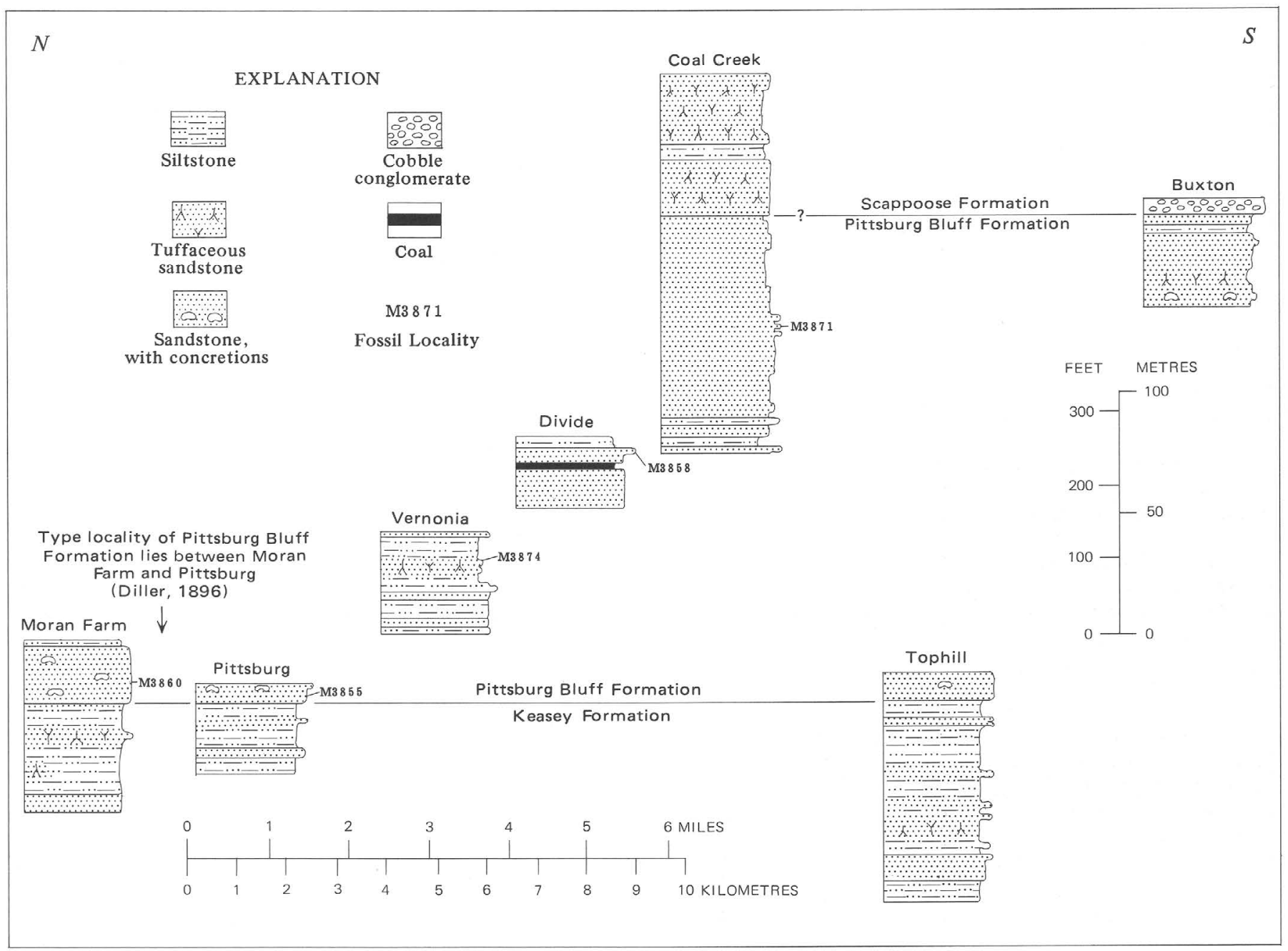

Figure 4.-Measured sections of the Pittsburg Bluff and adjacent formations, Vernonia area, Oregon. See figure 3 for locations.

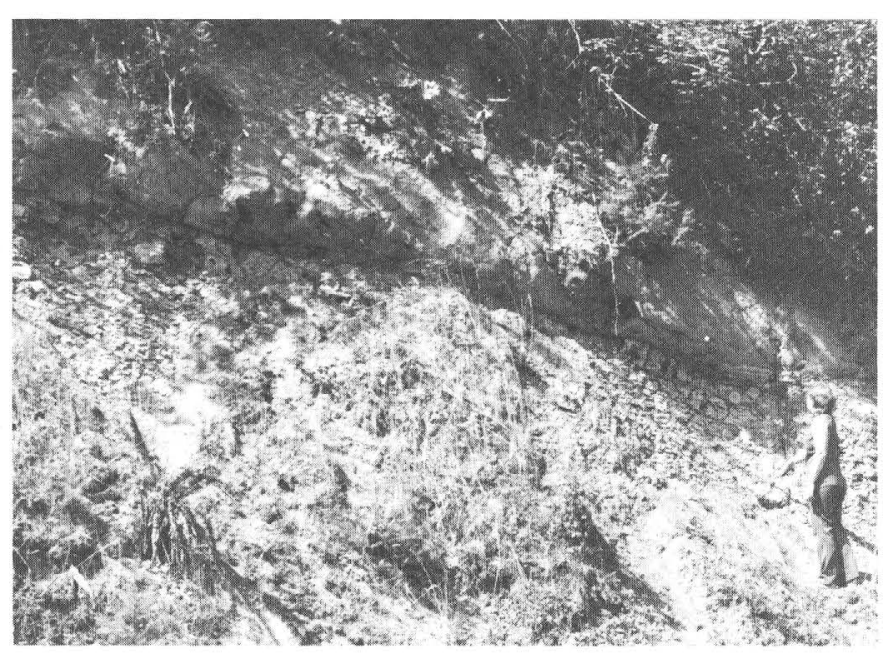

Figure 5.-Contact between siltstone of the Keasey Formation (below) and sandstone of the Pittsburg Bluff Formation (above), in roadcut along logging road $1 \mathrm{~km}$ southeast of Pittsburg, Oreg.

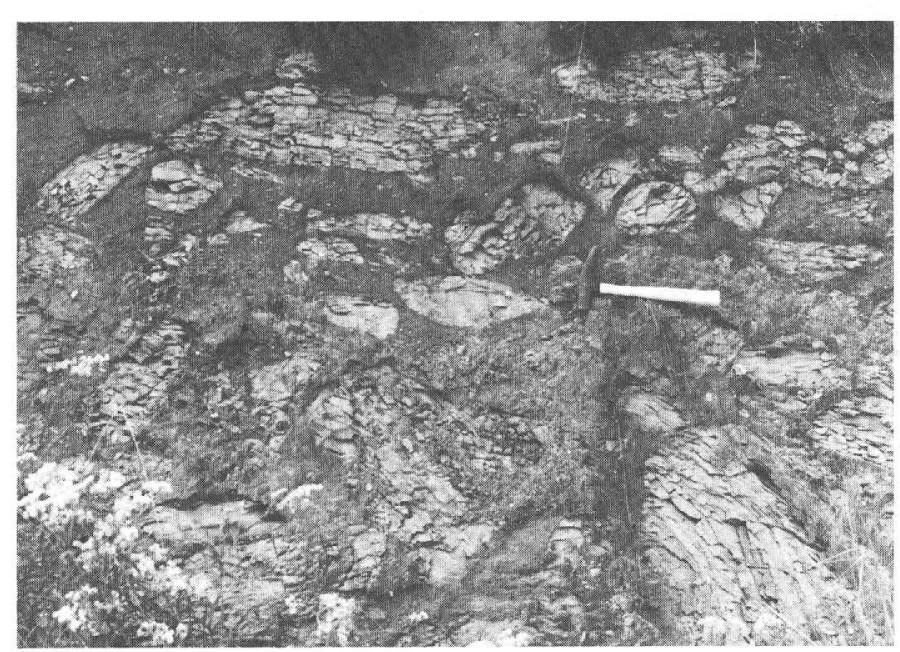

Figure 6. - Siltstone rip-up clasts in Pittsburg Bluff Formation in roadcut along logging road $2 \mathrm{~km}$ southeast of Pittsburg, Oreg. 
Scaphophod

Dentalium (Fissidentalium?) laneensis Hickman

Pelecypods

Nucula (Leionucula) vokesi, n. sp.

Acila (Truncacila) shumardi (Dall)

Litorhadia washingtonensis (Weaver)

Yoldia (Kalayoldia) oregona (Shumard)

Mytilus cf. M. snohomishensis Weaver

Lucinoma columbiana (Clark and Arnold)

Felaniella (Felaniella) snavelyi, n. sp.

Nemocardium (Keenaea) lorenzanum (Arnold)

Spisula (Mactromeris) pittsburgensis Clark

Tellina (Eurytellina) aduncanasa Hickman

Tellina? pittsburgensis Clark

Solen townsendensis Clark

Solena (Eosolen) eugenensis (Clark)

Panopea snohomishensis Clark

Panopea ramonensis Clark

Cochlodesma bainbridgensis Clark

Thracia (Thracia) condoni Dall

The pelecypods do not indicate any striking faunal break, but the gastropods do; 9 of 23 species are restricted to the lower part of the Pittsburg Bluff Formation. This break suggests, therefore, that two faunal zones may be present in the Pittsburg Bluff Formation in its type area, one in the lower $100 \mathrm{~m}$ and one in the upper.

\section{CHECKLIST OF PITTSBURG BLUFF SPEGIES}

Exposures of the Pittsburg Bluff Formation are found in an area of about $150 \mathrm{~km}^{2}$; they indicate a maximum thickness of approximately $200 \mathrm{~m}$. As paleontologists and geologists have been collecting fossil mollusks from the formation since the early 1900 's, it is reasonable to assume that their collections contain specimens of most of the animals with preserved hard parts that lived in the middle Oligocene sea of that part of northwestern Oregon. A checklist of the Pittsburg Bluff mollusks is given in table 1.

As most of the collections studied were made by other workers and had already been prepared, it was not possible to determine if all the specimens were collected from one stratigraphic interval, nor if each collection represented all the specimens available. Parts of the U.S. Geological Survey collections made by H. E. Vokes and others in the early 1940's had not been prepared. For these and my own collections, abundance could be accurately noted, and it was noted during my own collecting in the field.

The number of specimens representing a species in a collection of fossils is not necessarily related to the abundance of that species at a given fossil locality. If a species is easily removed from the enclosing rock, as are many of the naticids and also some pelecypods such as
Acila, it is apt to be collected in large numbers. If one attempts to remove a fragile valve of a pelecypod from its matrix in the field, it is likely to break up into small pieces which may or may not be brought back with the collection. If a genus, such as Turritella, Liracassis, or Acila, is known to be of special value for age determination, or is uniquely sculptured, the collector is likely to make a special search for it, and to exercise great care in removing it from the enclosing rock.

Even when a geologist is trying to collect a complete assemblage, he may fail to do so unless he collects everything he finds, for it is often difficult to distinguish similar species in the field. The abundance and variety of species in a collection may depend on the purpose for which the collection was made; fewer specimens are required for a determination of age than for a thorough study of a fauna.

In an attempt to estimate the relative abundance of species in the Pittsburg Bluff Formation as exposed in the area dealt with here, I have noted the number of specimens of each observed in the field and in collections prepared from slabs of rocks. For some species, the results thus obtained may be far from accurate, but no better method seems to be available. I have not given numbers of specimens for each locality but have adopted the terminology that Smith and Gordon (1948) used in reporting the abundance of species of living mollusks in Monterey Bay, Calif., and applied it to the fauna as a whole:

Abundant: found nearly everywhere, usually more than 20 specimens.

Common: usually found in moderate abundance (10 to 20 specimens).

Scarce: found at several localities, usually singly or only a few together

Rare: A total of only a few specimens found by me or known to have been collected by others.

The following list gives the relative abundance of species found in the Pittsburg Bluff Formation:

\section{Gastropods \\ Abundant}

Cryptonatica pittsburgensis, n. sp.

Polinices washingtonensis (Weaver)

Neverita (Glossaulax) thomsonae Hickman

Bruclarkia columbiana (Anderson and Martin)

Molopophorus gabbi Dall

Perse pittsburgensis Durham

Common

Perse pittsburgensis vernoniensis, $\mathrm{n}$. subsp.

Taranis columbiana (Anderson and Martin)

Spirotropis kincaidi (Weaver)

Suavodrillia winlockensis (Effinger)

Scaphander stewarti Durham 
TABLE 1.-Checklist of species at U.S. Geological Survey localities in the Pittsburg Bluff Formation arranged in approximate stratigraphic order

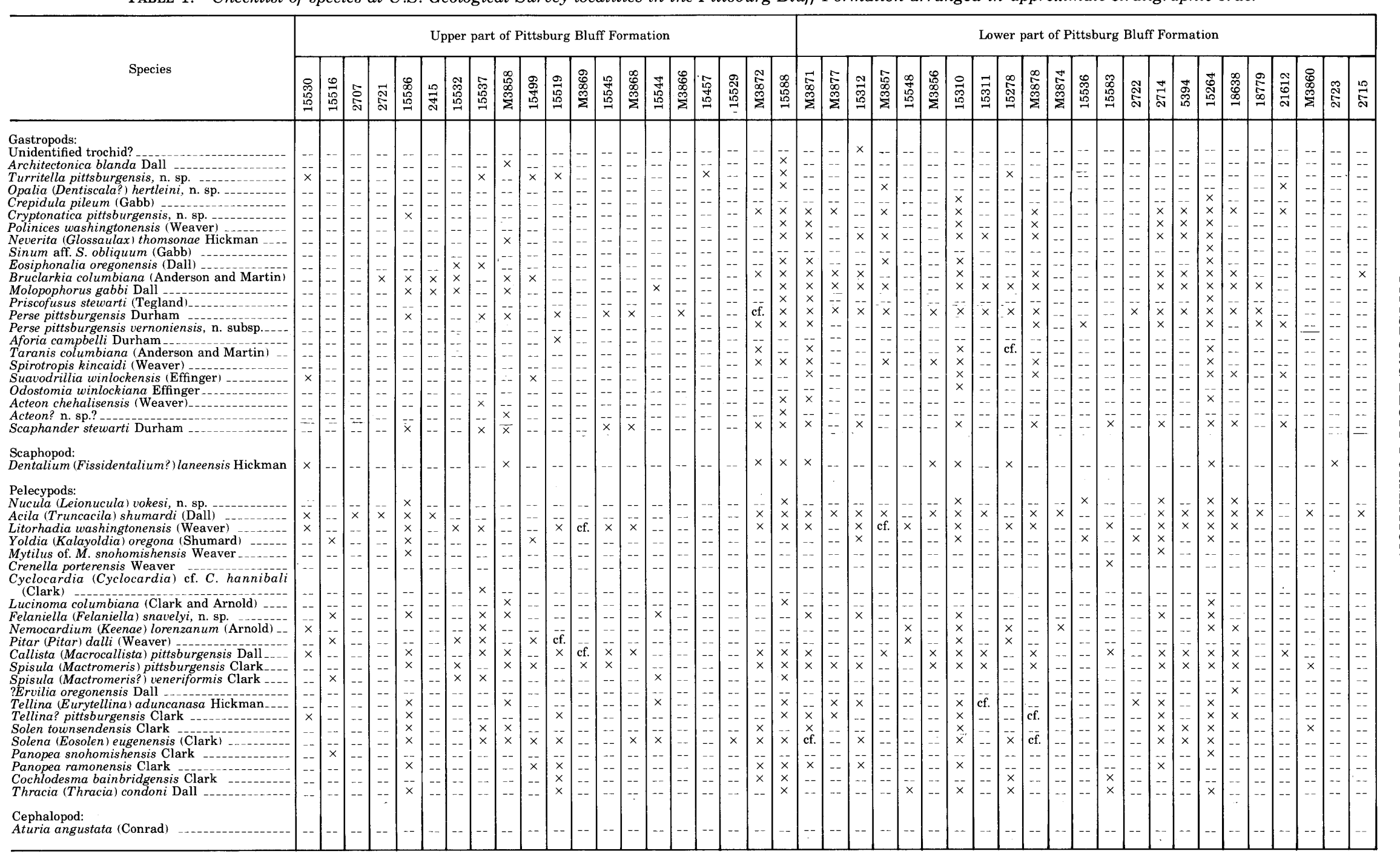


Scarce

Turritella pittsburgensis, $\mathrm{n}$. sp.

Eosiphonalia oregonensis (Dall)

Priscofusus stewarti (Tegland)

Acteon chehalisensis (Weaver)

Rare

Architectonica blanda Dall

Opalia (Dentiscala?) hertleini, n. sp.

Crepidula pileum (Gabb)

Sinum aff. S. obliquum (Gabb)

Aforia clallamensis wardi (Tegland)

Odostomia winlockiana Effinger

Scaphopod

Common

Dentalium (Fissidentalium?) laneensis Hickman

Cephalopod

Rare

Aturia angustata (Conrad)

Pelecypods

Abundant

Acila (Truncacila) shumardi (Dall)

Litorhadia washingtonensis (Weaver)

Callista (Macrocallista) pittsburgensis Dall

Spisula (Mactromeris) pittsburgensis Clark

$$
\text { Common }
$$

Yoldia (Kalayoldia) oregona (Shumard)

Felaniella (Felaniella) snavelyi, n. sp.

Tellina (Eurytellina) aduncanasa Hickman

Tellina pittsburgensis Clark

Solen townsendensis Clark

Solena (Eosolen) eugenensis (Clark)

Panopea ramonensis Clark

Thracia (Thracia) condoni Dall

$$
\text { Scarce }
$$

Nucula (Leionucula) vokesi, n. sp.

Lucinoma columbiana (Clark and Arnold)

Nemocardium (Keenaea) lorenzanum (Arnold)

Pitar (Pitar) dalli (Weaver)

Spisula (Mactromeris?) veneriformis Clark

Panopea snohomishensis Clark

$$
\text { Rare }
$$

Cochlodesma bainbridgensis Clark

Mytilus cf. M. snohomishensis Weaver

Crenella porterensis Weaver

Cyclocardia (Cyclocardia) cf. C. hannibali (Clark)

?Ervilia oregonensis Dall

\section{ECOLOGY}

The Pittsburg Bluff Formation contains 43 identified genera of mollusks represented by 48 species, almost equally divided between pelecypods and gastropods and including one scaphopod and one cephalopod. Five of the gastropod genera are extinct: Eosiphonalia, Molopophorus, Bruclarkia, Perse, and Priscofusus, and three are locally extinct: Architectonica, Sinum, and Turritella. The pelecypod subgenus Eosolen is apparently restricted to the Eocene and Oligocene, and so is Litorhadia, which some authors classify as a subgenus of Nuculana.

Thirteen of the total of 48 species are so abundant that almost any persistent collector would find them. Fourteen species are so rare that only one to five specimens of each have been found, presumably as the result of exhaustive collecting. The remaining 21 species are represented, on the average, by about 20 specimens each and may be assumed to constitute an important part of the fauna. A striking characteristic of the Pittsburg Bluff fauna is that an enormous number of fossils of a few species are tightly packed in the calcareous concretions and lenses within the formation. These are Callista (Macrocallista) pittsburgensis, Acila (Truncacila) shumardi, Molopophourus gabbi, Perse pittsburgensis, and the four naticid species that the formation contains.

The pelecypods, with the exception of two small mytilids represented only by incomplete shells, are characteristic of an infauna (Thorson, 1957) that lived buried or burrowing in muddy sand on the sea bottom. Of the gastropods, all but Crepidula (represented by one well-preserved and three poorly preserved specimens) lived on or within the sediment of the sea floor. Rare or absent are forms that lived only on rocky shores or on an open sandy beach. Several of the genera that are particularly abundant in the fauna-for example Polinices and Neverita - are known to be voracious feeders on clams (Hedgpeth and Hinton, 1961; Keen, 1971). Gastropods of the extinct genera Eosiphonalia, Bruclarkia, Perse, and Molopophorus, which lack the round aperture usually possessed by herbivorous snails, have long siphonal canals, indicating that they may have been detritus feeders or carnivores, preying upon clams; their familial assignments, if correct, imply that they were carnivores. The drill holes found in some pelecypod valves are straight sided, similar to the holes made by the Muricacea, none of which are known from the Pittsburg Bluff Formation, unless one of these extinct genera is missassigned. The formation also contains Turritella, which is known to live buried just beneath the sea floor and to feed upon detritus; Opalia, which is a carnivorous genus, with some species known to feed upon sea anemones and corals (Keen, 1971); and Odostomia, which is known to be parasitic upon other mollusks such as Ostrea, Pecten, and Crepidula, and upon polychaete worms (Keen, 1971). The only scaphopod represented is Dentalium, which lives buried under a thin layer of sediment on the sea floor (Keen, 1963), and the only cephalopod is Aturia, which presumably inhabited moderately shallow water and 
was carnivorous, perhaps feeding on decapod crustaceans (Miller, 1947, p. 13) or mollusks.

The Pittsburg Bluff molluscan fauna contains none of the rock dwellers of the littoral zone with the possible exception of Mytilus, and no snails that are known to be herbivorous. None of the mollusks found in the formation, except the turrids, are considered indicative of deep water. No remains of echinoderms or crabs have been found, and foraminifers are represented by two poorly preserved globigerinids. Some fish remains have been found; the teeth identified are of sharks and rays. Welton (1972, p. 168) makes the following statement concerning the shark teeth:

***the lower sections of the Pittsburg Bluff Formation yield numerous teeth of a small squalid shark Centroscymnus and not uncommonly teeth of Raja, Squatina, Odontaspis, Squalus, Pristiophorus, and Notorhynchus. These genera, plus several additional forms, collectively constitute the most diverse assemblage yet known from the middle Oligocene of Oregon.

Otoliths from USGS 15310, in the middle part of the Pittsburg Bluff Formation, were identified by John E. Fitch, California Department of Fish and Game, as belonging to the families Congridae (conger eels) and Macrouridae (rat tails), both bottom-dwelling families that typically inhabit moderate $(200 \mathrm{~m})$ to great depths $(500 \mathrm{~m})$, and, although found in all oceans of the world, are least common in tropical seas (John E. Fitch, written communs., May 23, 1973, and June 18, 1973).

From the preserved molluscan fauna, a picture emerges of an infaunal community of filter feeders, detritus feeders, and carnivores living on or within the sediment of the sea floor.

The table below (table 2, compiled from Abbott, 1954;

TABLE 2.-Holocene genera in the Pittsburg Bluff Formation and their preferred bottom sediment and water depth

\begin{tabular}{|c|c|c|}
\hline Genera & Bottom sediment & Depth of water \\
\hline \multicolumn{3}{|c|}{ Gastropods } \\
\hline Architectonica $\ldots$ & $\begin{array}{l}\text { Common in sand and } \\
\text { sand-mud bottom. }\end{array}$ & Tideflats to $60 \mathrm{~m}$ \\
\hline Turitella & Soft bottom, sand or mud. & Subtidal to $180 \mathrm{~m}$ \\
\hline Opalia (Dentiscala) & $\begin{array}{l}\text { At base of sea anemones, } \\
\text { under kelp. }\end{array}$ & $\begin{array}{l}\text { Usually less than } 15 \text { but may } \\
\text { be as much as } 90 \mathrm{~m} \text {. }\end{array}$ \\
\hline Crepidula -- & Rock or shell. & Intertidal to $160 \mathrm{~m}$ \\
\hline Cryptonatica & Sand. & Intertidal to $1,600 \mathrm{~m}$. \\
\hline Polinices (Polinices) & $\begin{array}{l}\text { Bay sand flats, mud flats, } \\
\text { clay. }\end{array}$ & Intertidal to $2,500 \mathrm{~m}$. \\
\hline Neverita (Glossaulax) & Sand bars, bay sand flats. & Intertidal to $45 \mathrm{~m}$. \\
\hline Sinum & $\begin{array}{l}\text { Sand or mud flats } \\
\text { among small stones. }\end{array}$ & Intertidal to $45 \mathrm{~m}$. \\
\hline \multirow[t]{2}{*}{ Aforia } & - & 60 to $2,500 \mathrm{~m}$ \\
\hline & & $\begin{array}{l}\text { Bipolar; descends into deep } \\
\text { equatorial waters for requis } \\
\text { ite bottom temperature. }\end{array}$ \\
\hline \multicolumn{3}{|r|}{180 to $750 \mathrm{~m}$} \\
\hline \multicolumn{2}{|l|}{ Spirotropis } & 730 to $3,650 \mathrm{~m}$ \\
\hline Odostomia & $\begin{array}{l}\text { Parasitic on mollusks; } \\
\text { common near eelgrass } \\
\text { roots. }\end{array}$ & Intertidal to $640 \mathrm{~m}$. \\
\hline \multirow{2}{*}{$\begin{array}{l}\text { Acteon } \\
\text { Scaphander }\end{array}$} & Sand, bay-mud flats. & Intertidal to $75 \mathrm{~m}$. \\
\hline & - & 20 to $5,200 \mathrm{~m}$. \\
\hline
\end{tabular}

TABLE 2.-Holocene genera in the Pittsburg Bluff Formation and their preferred bottom sediment and water depth-Continued

\begin{tabular}{rrr}
\hline Genera & Bottom sediment & Depth of water \\
\hline & Scaphopod \\
\hline & & 7 to $1,200 \mathrm{~m}$
\end{tabular}

Dentalium (Fissidentalium) _._. 7 to $1,200 \mathrm{~m}$.

Pelecypods

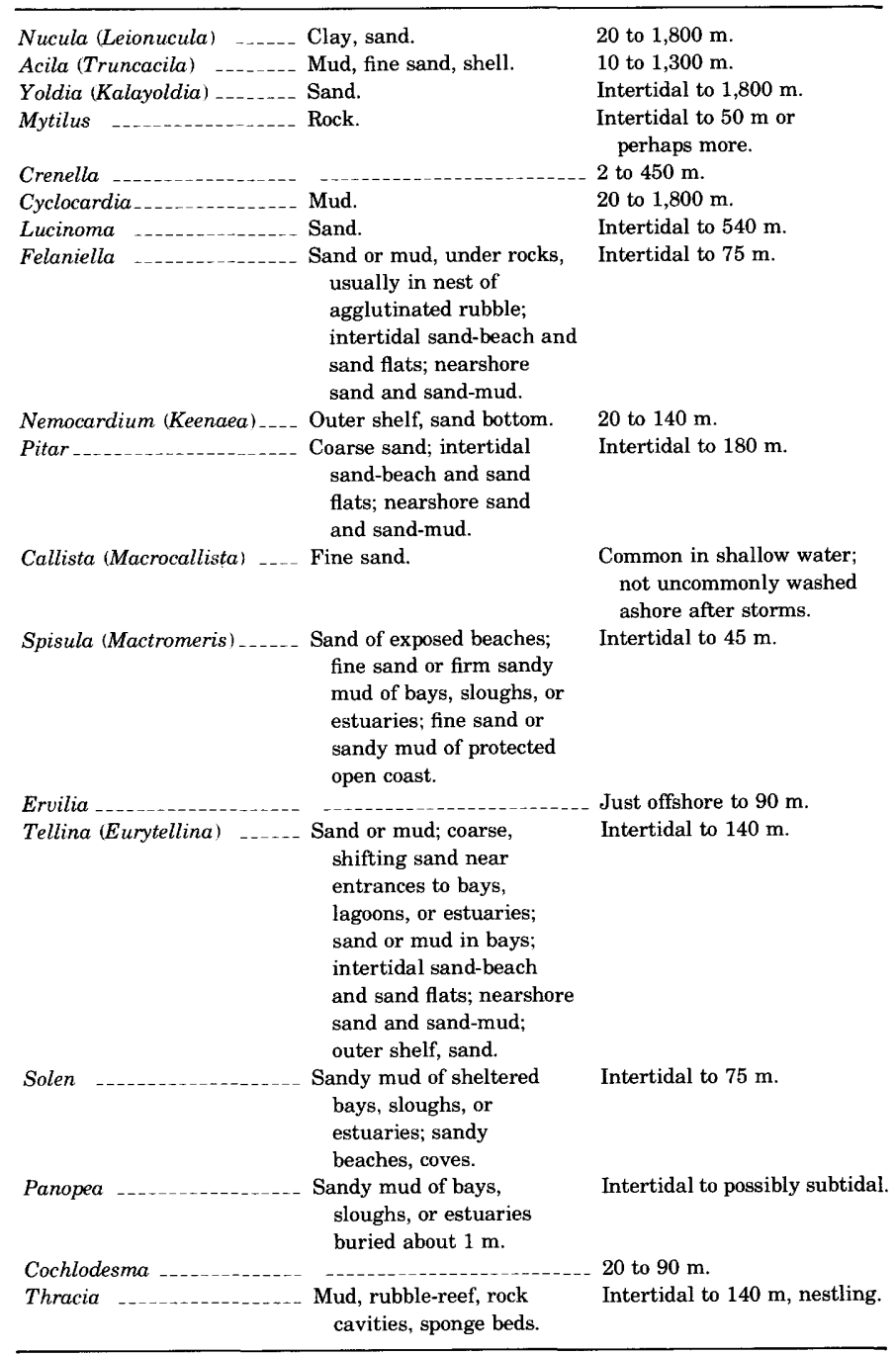

Berry, 1954; Burch, 1944-46; Eyerdam, 1960; Fitch, 1953; Hedgpeth and Hinton, 1961; Javidpour, 1973; Keen, 1963, 1971; McLean, 1969; Oldroyd, 1924; Packard, 1918; and Parker, 1963) shows the known depth of water and bottom sediment inhabited by Holocene genera represented in the Pittsburg Bluff fauna.

Although none of the Pittsburg Bluff molluscan fossils have been found in life position, many pelecypods are preserved as articulated specimens; this fact suggests that they were transported rapidly or a relatively short distance. Fragments of shells make up 50 percent of the matrix, and these fragments represent 
the same species of mollusks that are found as entire specimens. All the species found together did not necessarily live together in identical environments or at the same depth. Three habitats are suggested-one of deep water, perhaps at least $100 \mathrm{~m}$; one of moderately shallow water, perhaps about $20 \mathrm{~m}$; and one of shallow, nearshore water, less than 20 and some of it intertidal. None of the genera lived in high-energy coastal environments.

The following genera and subgenera are considered indicative of sand or mud flats, bars, or shallow protected bays:

\section{Gastropods}

Opalia (Dentiscala)
Polinices (Polinices)
Neverita
Sinum
Acteon
$\quad \quad$ Pelecypods
Felaniella
Pitar
Spisula (Mactromeris)
Tellina (Eurytellina)
Solen
Panopea

Genera and subgenera that usually occur together at depths of $20 \mathrm{~m}$ or more, but not as a rule intertidally, include the following:

\section{Gastropods}

Turritella

Scaphander

$\quad$ Scaphopod
Dentalium
$\quad$ (Fissidentalium?)
$\quad$ Pelecypods
Nucula (Leionucula)
Acila (Truncacila)
Yoldia (Kalayoldia)
Crenella
Cyclocardia
Nemocardium (Keenaea)
Ervilia
Cochlodesma
Thracia

Of these, Yoldia and Thracia occur intertidally as well as at depths of more than $20 \mathrm{~m}$.

The turrids Taranis, Spirotropis, and Aforia have been found at depths no shallower than 180,730 , and 60 $\mathrm{m}$ respectively. But of the 10 collections made at localities in which the turrids are common, 2 contain Neverita (Glossaulax), which lives intertidally to $45 \mathrm{~m}, 1$ contains Spisula, which lives intertidally to $45 \mathrm{~m}$; and 4 contain Panopea, which is intertidal to possibly subtidal. These facts indicate either that the turrids lived in much shallower water during middle Oligocene time than they do now, or that their shells were mixed, before being fossilized, with the shells of genera with which they did not live.

Thin coal seams, found in the Pittsburg Bluff Formation, indicate that the marine environment of the Pittsburg Bluff Formation was at times intertidal or supratidal. None of the mollusks found near the coal beds, however, are indicative of brackish water.

If the Pittsburg Bluff fauna is regarded as primarily representing a single habitat, it must have lived for the most part in water from about 20 to about $50 \mathrm{~m}$ in depth. Mytilus and Panopea perhaps were carried in mechanically from shallower water, although Mytilus is found at a depth of $45 \mathrm{~m}$ and Panopea is believed to enter the subtidal realm. In addition, the fossilized valves of Panopea in the Pittsburg Bluff fauna are usually articulated, so that if they were moved any appreciable distance, they must have moved rapidly. The shoreline must presumably have fluctuated sufficiently to include the coal. The turrids, unless the bathymetric data for the Holocene genera are nonrepresentative, are incompatible with a 20 - to $50-\mathrm{m}$ depth habitat. It seems more probable that the Pittsburg Bluff fauna includes species from three distinct habitats, brought together by transportation. Some of the mollusks must have been moved about for long periods of time or have been abraded in a high-energy environment for, as stated earlier, about half of the matrices of the mollusks consist of worn shell fragments of the same species as those that are found whole. The complete shells enclosed in this fragmental material are well preserved, and most of the pelecypod valves are articulated and closed.

In addition to the closed and articulated valves of strongly hinged Acila, less strongly hinged Callista, Spisula, Solen, Eosolen, and Panopea are usually preserved with both valves closed, and fine sculpture is preserved on most of the gastropods. These wellpreserved shells could not have been rolled by waves or currents for long distances; they cannot, on the other hand, have been fossilized where they lived, as none have been found in life position, and fossil remains of organisms that must have lived at different depths, in terms of modern known bathymetric ranges, are commonly assembled.

The concentrated fossilized shells and shell fragments may have been brought together in stormy periods. At the present time, after a storm on the coast of 
southern California, one may find on the shores of coves large quantities of newly assembled worn shell debris mixed with unworn whole shells of Cypraea, Olivella, Astraea, Haliotis, Fissurella, Tegula, and other gastropods, and often large numbers of pelecypods, such as Mytilus, that have been washed in while they were alive, with their valves articulated and closed. After one fall storm at Jones Beach on the Atlantic Ocean side of Long Island, New York, mature specimens of Spisula solidissima Dillwyn, Neverita duplicata (Say), and the seastar Brisaster were piled up along the shore to a depth of $0.3 \mathrm{~m}$ over a distance of about $0.8 \mathrm{~km}$. All these animals were alive, and the valves of Spisula were articulated and closed; none of them are commonly found on the beach in calm weather (Anthony D'Attilio, oral commun., 1973). Similar accumulations of live but displaced animals may be formed even more commonly in the subtidal zone.

If the intertidal genera cited lived on sand or mud bars in a bay, they would have been especially vulnerable to transportation and fairly rapid redeposition during storms.

The composition of the molluscan fauna remained generally the same throughout the deposition of the Pittsburg Bluff Formation. Mixtures of shells and shell debris from animals that lived at different depths occur throughout the section.

The Pittsburg Bluff Formation is a transgressive unit that prograded westward over the deeper water Keasey Formation. Its thickness of $100 \mathrm{~m}$ or more from the base to the first coal bed may give a rough measure of the greatest water depth during its deposition. The sediments in the lower part of the formation and much of the sediments in the upper part are believed to have been carried to their present position by grain flowage (Stauffer, 1967) on a seaward-building slope at the margin of a basin. Sediment continuously spilled over the shelf edge and was then moved periodically into deeper water by grain flowage. This mechanism was responsible for the mixing of faunas characteristic of different depths. It also, by juxtaposing species of different facies at a time of fairly rapid speciation and extinction, contributed to the sharp faunal contrast between the Pittsburg Bluff Formation and the underlying Keasey Formation.

Evidence regarding the temperature at which the Pittsburg Bluff fauna lived is somewhat contradictory. Modern Truncacila prefers a cool-temperate habitat. Most species of Crenella live in cool water, and Lucinoma prefers cool water. Panopea is usually found in areas of temperate climate, although it ranges into warm temperate waters. Yoldia (Kalayoldia) cooperi, probably a close relative of the extinct species of Yoldia in the Pittsburg Bluff Formation, now lives no farther north than central California. The extinct Litorhadia, which is common in the Eocene of Alabama and is there associated with warm-water genera, probably preferred warm water, unless it had a broad tolerance. Callista is usually found in warm water.

Cryptonatica is commonly a boreal form and Aforia prefers cool water. Neverita (Glossaulax) reclusiana, probably closely related to the extinct Pittsburg Bluff species, lives no farther north than southern California. The extinct genera Eosiphonalia, Bruclarkia, Molopophorus, Priscofusus, and Perse are all moderately well sculptured, a fact indicating that they may have preferred warm water, and all these extinct genera except Eosiphonalia and Bruclarkia occur in the Eocene of California, a further indication of possible preference for warm water. Architectonica, a tropical genus, is found in the upper part of the Pittsburg Bluff sections near coal beds, perhaps indicating shallower and, therefore, warmer water.

Some species, such as Acila (Truncacila) shumardi and Callista (Macrocallista) pittsburgensis, ranged from the Alaska Peninsula to California in middle Oligocene time. This wide geographic range may result from any one of three causes: these species may have been able to tolerate unusually wide temperature ranges; the favorable temperature may have been produced by differences in local water depth or by upwelling; or the surface temperature of the sea may have been more uniform in Oligocene time than it is today.

In summary, the fauna is neither tropical nor boreal in overall aspect; it seems to indicate a warm-temperate sea.

Tropical and subtropical molluscan genera lived only at low latitudes during the Oligocene and at higher latitudes during the Miocene, after which they steadily retreated southward. Addicott $(1969,1970 a)$ has inferred from these facts that there was a marked cooling in middle Oligocene time, but the Pittsburg Bluff fauna does not seem to support this view.

\section{RELATION TO OTHER OLIGOCENE FAUNAS IN OREGON}

Only a few species are common to both the Keasey and Pittsburg Bluff Formations in the Vernonia area. In the past this was explained by assuming that the two formations were separated by an unconformity or disconformity, marking a time interval sufficiently long to account for the faunal change; but if the two formations are conformable, as indicated by the present study, this explanation is no longer valid. The species common to both formations are:

$$
\text { Gastropods }
$$

Sinum aff. S. obliquum

(Gabb)

Scaphander stewarti

Durham 
A few more genera are common to the two formations but are represented by different species. They are:

\begin{tabular}{ll}
$\quad$ Gastropods & \multicolumn{1}{c}{ Pelecypods } \\
Cryptonatica & Nucula \\
Polinices & Acila \\
Bruclarkia & Yoldia \\
Spirotropis & Thracia \\
& Pitar
\end{tabular}

Most of the molluscan genera do not occur in both formations. Genera that occur only in the Keasey or only in the Pittsburg Bluff Formation are:

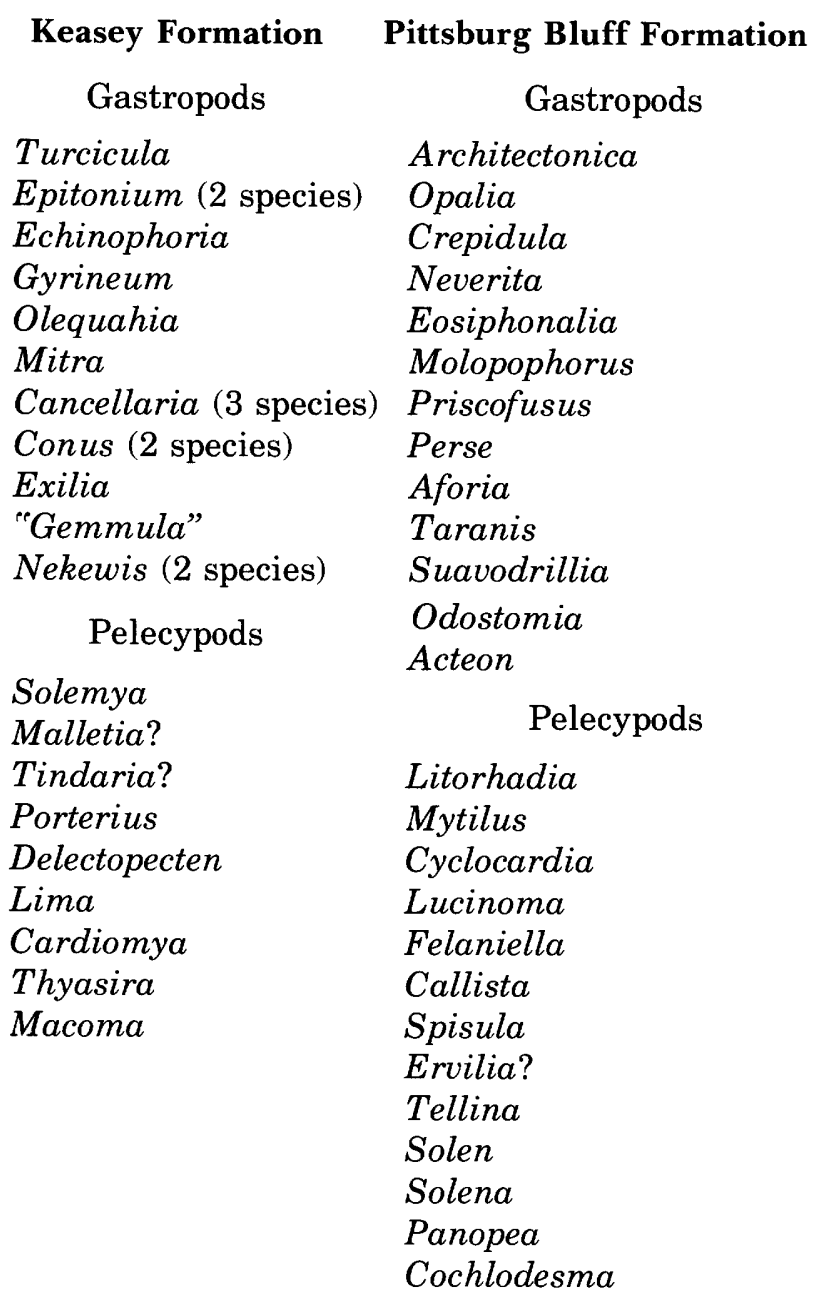

Although none of the Pittsburg Bluff genera in these lists, except for the turrids, now usually live in moderately deep water at depths below $50 \mathrm{~m}$, several Keasey genera do; among these are Turcicula, Phanerolepida, Solemya, Delectopecten, and Thyasira. The entire Keasey fauna suggests depths greater than $50 \mathrm{~m}$, as the average modern bathymetric range of the Holocene genera represented is about $40-130 \mathrm{~m}$.

The fauna of the middle Keasey, which is especially well preserved, includes many forms that have seldom. been found fossilized in other Tertiary sections (Zullo and others, 1964, p. 333). The echinoid Salenia is represented at one locality by several hundred specimens, many of which have their spines still intact. At the same locality, the crinoid Isocrinus is found with the arms attached to the calyx. The following taxa are reported from the upper middle Keasey Formation at Mist, Oreg. (Zullo and others, 1964, p. 334-335):

\begin{tabular}{|c|c|}
\hline Taxa & Abundance \\
\hline \multicolumn{2}{|l|}{ Foraminifera } \\
\hline Operculina sp & Rare \\
\hline \multicolumn{2}{|l|}{ Plectofrondicularia packardi } \\
\hline Cushman and Schenck & Abundant \\
\hline \multicolumn{2}{|l|}{ Coelenterata } \\
\hline Caryophyllia sp. indet & One specimen \\
\hline Flabellum hertleini Durham _--- & $\begin{array}{l}\text { Thirty-two specimens } \\
\text { in a block with } \\
\text { a surface area } \\
\text { of } 520 \mathrm{~cm}^{2} \text {. }\end{array}$ \\
\hline Gorgonid coral & One specimen \\
\hline \multicolumn{2}{|l|}{ Pelecypoda } \\
\hline \multicolumn{2}{|l|}{$\begin{array}{l}\text { Acila }(\text { Truncacila }) \\
\text { nehalemensis Hanna }\end{array}$} \\
\hline Delectopecten $\mathrm{sp}$ & Several \\
\hline \multicolumn{2}{|l|}{ Ennucula sp. } \\
\hline \multicolumn{2}{|l|}{ Minormalletia sp. } \\
\hline \multicolumn{2}{|l|}{$\begin{array}{l}\text { Nuculana aff. } N . \text { washingtonensis } \\
\text { (Weaver) }\end{array}$} \\
\hline \multicolumn{2}{|l|}{ Propeamussium n. sp. } \\
\hline $\begin{array}{l}\text { Solemya }(\text { Acharax }) \\
\quad \text { willapaensis } \text { Weaver }\end{array}$ & Solemya (Acharax) \\
\hline \multicolumn{2}{|l|}{ Tellina sp. } \\
\hline \multicolumn{2}{|l|}{ Yoldia (Portlandella) } \\
\hline \multicolumn{2}{|l|}{ chehalisensis (Arnold) } \\
\hline \multirow{2}{*}{\multicolumn{2}{|c|}{$\begin{array}{l}\text { Gastropoda } \\
\text { "Cancellaria" sp. }\end{array}$}} \\
\hline & \\
\hline \multicolumn{2}{|l|}{ Epitonium keaseyensis Durham } \\
\hline \multicolumn{2}{|l|}{ Exilia lincolnensis Weaver } \\
\hline \multicolumn{2}{|l|}{ Fulgurofusus n. sp. } \\
\hline \multicolumn{2}{|l|}{ Polinices n. sp. } \\
\hline \multicolumn{2}{|l|}{ Scaphander stewarti Durham } \\
\hline \multicolumn{2}{|l|}{ Arthropoda } \\
\hline Fragmentary crustacean remains & Few \\
\hline \multicolumn{2}{|l|}{ Crinoidea } \\
\hline \multicolumn{2}{|l|}{ Isocrinus nehalemensis } \\
\hline Moore and Vokes -- & Several \\
\hline \multicolumn{2}{|l|}{ Isocrinus oregonensis } \\
\hline Moore and Vokes & Common \\
\hline \multicolumn{2}{|l|}{ Asteroidea } \\
\hline Brisingid? n. sp & One specimen \\
\hline Astropecten? n. sp & Three specimens \\
\hline Unidentified asteroids & Two specimens \\
\hline Ophiuroidea & \\
\hline Unidentified ophiuran & One specimen \\
\hline Echinoidea & \\
\hline Brisaster maximus Clark? & One specimen \\
\hline Salenia schencki Kaar & Several hundred \\
\hline Vertebrata & \\
\hline Fish scales & Common \\
\hline Plantae & \\
\hline $\begin{array}{l}\text { Coralline algae } \\
\text { "Zostera" sp. (with attached }\end{array}$ & One fragment \\
\hline diatoms) & Few \\
\hline
\end{tabular}




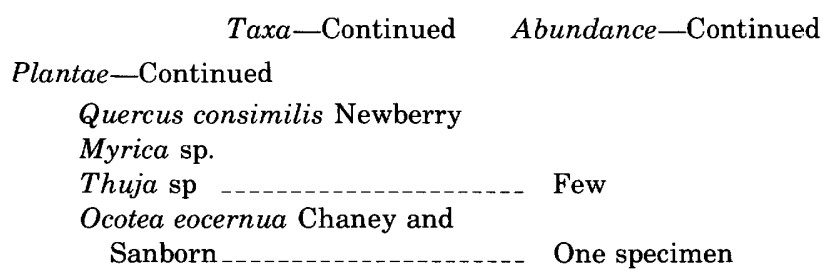

This biota represents a mixed depth assemblage. It includes, for example, the eelgrass Zostera, which lives at depths of less than $15 \mathrm{~m}$, and the coral Flabellum and the echinoid Salenia, which both suggest a depth of about $360 \mathrm{~m}$ (Zullo and others, 1964, p. 335). The intact skeletons of the echinoids, seastars, and crinoids further suggest that these animals lived at a depth of more than $150 \mathrm{~m}$, undisturbed by waves and currents. The gastropod Phanerolepida has been found in the middle member of the Keasey Formation; it lives today at depths of $600-800 \mathrm{~m}$ (Hickman, 1972). Moore and Vokes (1953, p. 140) inferred, from the abundance of tuff in the middle and upper members of the Keasey Formation, which also contains lapilli at least $1 \mathrm{~cm}$ in diameter, that the source of the volcanic debris was nearby. Since no evidence of submarine volcanic activity was seen to account for the ash, Moore and Vokes (1953, p. 118) believed that the Keasey shoreline was only a few miles away.

About $4 \mathrm{~km}$ north of Mist, Oreg., fossiliferous conglomerate and massive sandstone are exposed. Warren, Grivetti, and Norbisrath (1945) assigned them to the Gries Ranch Formation of early Oligocene age. They believed that this part of the Gries Ranch Formation might be equivalent to the upper part of the Keasey Formation at Vernonia and that part of the Keasey contains species found in the type Gries Ranch fauna. Warren and Norbisrath (1946, p. 228) believed that the faunal differences between the two might be ascribed to different ecologic conditions. The Gries Ranch at this Oregon locality contains the following genera that do not occur in either the Keasey or Pittsburg Bluff Formations:
Gastropods

Puncturella Alvania

\section{Pelecypods}

Glycymeris

Arca

Barbatia

Loxocardium
As species of all these genera now live in intertidal environments, some of them on or under loose fragments of rock, it seems likely that at least the upper part of the Gries Ranch Formation was deposited within a few kilometres of the shoreline. Absence of the genera in the Keasey may be due to an uncongenial depth of water.
The upper part of the Keasey Formation contains the deepwater genus Turcicula. The upper part does not contain the generally deep-water genera Solemya, Propeamussium, Delectopecten, Thyasira, and Spirotropis. This fact may indicate a slight shoaling of the sea in late Keasey time.

One fossil collection (USGS M3874) from a siltstone of Keasey-like lithology taken near the base of the Pittsburg Bluff Formation contains Nemocardium lorenzanum. This species also occurs in the upper Keasey. In the type locality of the Pittsburg Bluff Formation, however, sandstone only a few metres above the base yields a typical Pittsburg Bluff fauna. The distribution of $N$. lorenzanum at this place is believed to have been ecologically controlled; it could live in the facies represented by the siltstone but not in the sandstone facies.

Acila (Truncacila) nehalemensis was collected in the Keasey Formation about $2 \mathrm{~m}$ below its top (USGS M3864). Acila (Truncacila) shumardi is common throughout the lower part of the Pittsburg Bluff Formation in the type area. These two very distinct species of Acila occur only a few metres apart, the one in the Keasey and the other in the Pittsburg Bluff. They are, however, in different kinds of rock, $A$. (T.) nehalemensis in shale and $A$. (T.) shumardi in sandstone. In the Gries Ranch Formation in northwestern Oregon, the Pittsburg Bluff species $A$. (T.) shumardi is found rather than the Keasey species $A$. $(T$.) nehalemensis, but as the Gries Ranch Formation was deposited in much shallower water than the Keasey, this difference can be attributed to a difference of environment.

In the Eugene area, about $200 \mathrm{~km}$ south of Pittsburg, Oreg., the Eugene Formation, of early and middle Oligocene age, contains both Keasey and Pittsburg Bluff species. Although some typical Pittsburg Bluff species, such as Callista pittsburgensis, Acila shumardi, and Bruclarkia columbiana, do not appear until high in the section, other Pittsburg Bluff species, such as Tellina pittsburgensis, Solena eugenensis, Thracia condoni, Litorhadia washingtonensis, Tellina aduncanasa, Polinices washingtonensis, and Neverita thomsonae, are present lower in the section, and are all associated with typical Keasey forms (Hickman, 1969, p. 11). The Eugene Formation, which interfingers with terrestrial deposits, consists entirely of coarse- to fine-grained sandstone, whereas sediments of presumably the same stratigraphic interval are represented in northwestern Oregon by fine-grained sandstone and siltstone of the Pittsburg Bluff Formation and shale of the Keasey Formation. These differences of lithology indicate that the two areas offered somewhat different ecologic habitats. 
High in the Eugene Formation, where typical Pittsburg Bluff species are common, the following genera were found that do not occur in the Pittsburg Bluff Formation:

$$
\begin{aligned}
& \text { Gastropods } \\
& \text { Epitonium } \\
& \text { Acrilla } \\
& \text { Calyptraea } \\
& \text { Ficus } \\
& \text { Olequahia } \\
& \text { Exilia } \\
& \text { Gemmula } \\
& \text { Cylichnina }
\end{aligned}
$$

Pelecypods

Modiolus
Parvicardium
Pseudocardium
Macoma
Semele
Mya
Pandora
Opertochasma
Martesia

Most of these mollusks from the Eugene Formation could have lived within the environmental range of the Pittsburg Bluff Formation, both as to depth and seasurface temperature. The following genera occur in the Keasey but not in the Eugene Formation:

$\begin{array}{ll}\text { Gastropods } & \text { Pelecypods } \\ \text { Turritella } & \text { Solemya } \\ \text { Echinophoria } & \text { Ennucula } \\ \text { Gyrineum } & \text { Minormalletia } \\ \text { Mitra } & \text { Tindaria? } \\ \text { Cancellaria } & \text { Porterius } \\ \text { Spirotropis } & \text { Delectopecten } \\ \text { Nekewis } & \text { Lima } \\ \text { Knefastia } & \text { Cardiomya } \\ & \text { Thyasira }\end{array}$

As the mean depth at which many of these genera now live (40-100 $\mathrm{m}$ or more) is greater than the mean indicated by the inner neritic Eugene fauna as a whole, some of the Keasey Formation may have been deposited in deeper water than any part of the Eugene Formation. Crinoids are not found in the Eugene Formation, reinforcing the conclusion that the habitat was different from that of the Keasey and that it differed in some respect other than sea-surface temperature, since the two geographic areas are only about $200 \mathrm{~km}$ apart.

The known distribution of genera in the lower, middle, and upper Keasey is shown in table 3 along with genera that also occur in the Eugene and Pittsburg Bluff Formations.

In the Coos Bay area, about $260 \mathrm{~km}$ southwest of Pittsburg, Oreg., the middle Oligocene Tunnel Point Sandstone rests conformably upon the Bastendorff Shale (late Eocene and early Oligocene). The molluscan fauna of the Tunnel Point is reported to contain typical Pittsburg Bluff species and no Keasey species. Genera found by Weaver (1945, p. 51) in the Tunnel Point but not in the Pittsburg Bluff are:

$\begin{array}{ll}\text { Gastropods } & \text { Pelecypods } \\ \text { Exilia } & \text { Corbis } \\ \text { Neptunea } & \text { Macoma } \\ & \text { Pachydesma } \\ & \text { Pecten } \\ & \text { Pholas } \\ & \text { Thyasira }\end{array}$

The underlying Bastendorff Shale contains no Tunnel Point species. Its meager molluscan fauna includes Acila aff. A. decisa (Conrad), Nuculana cf. N. merriama (Dickerson), Spisula cf. S. packardi Dickerson, Cylichnina turneri Effinger, and Dentalium cf. $D$. porterensis Weaver. Of the 16 foraminifers reported by Weaver (1945, p. 49) in the Bastendorff, 7 occur in the Keasey. The foraminifers in the upper $300 \mathrm{~m}$ of the Bastendorff Shale indicate moderately deep to abyssal water depths (Kleinpell, 1938, p. 102). So even though Coos Bay is much farther south and nearer to the pre-

\begin{tabular}{|c|c|c|c|c|c|}
\hline Pelecypods: & & & & & \\
\hline Solemya & $x$ & $\times$ & - - - & --.- & -_-_ \\
\hline Ennucula & $\ldots$ & $x$ & $\ldots$ & --- & $-\ldots$ \\
\hline Acila (Truncacila) & $x$ & $x$ & 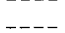 & $x$ & $\times$ \\
\hline Nuculana & $\ldots$ & $x$ & --- & $x$ & 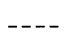 \\
\hline Yoldia & --- & $\hat{x}$ & $\begin{array}{ll}---- \\
---1\end{array}$ & $x$ & $x$ \\
\hline Minormalletia & ---- & $x$ & --- & - & $-\ldots$ \\
\hline Porterius & ---1 & 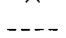 & $\times$ & -n- & --- \\
\hline Propeamussium & ---- & $x$ & 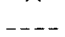 & --- & --- \\
\hline Delectopecten & $---{ }_{-1}$ & $x$ & -- & --- & -- \\
\hline Lima & $\begin{array}{l}--- \\
---\end{array}$ & - - - & $x$ & - & $-\ldots$ \\
\hline Crenella & $\begin{array}{l}---- \\
----\end{array}$ & $\times$ & --- & $\times$ & $x$ \\
\hline Thracia & --- & $x$ & --- & $x$ & $x$ \\
\hline Thyasira & $x$ & $x$ & - & $\ldots$ & $\ldots$ \\
\hline Nemocardium & $\ldots$ & $x$ & $x$ & $\times$ & $\times$ \\
\hline Fimbria & $x$ & $-\ldots$ & --- & $\ldots$ & $\ldots$ \\
\hline Pitar & $x$ & $\begin{array}{ll}---1 \\
---1\end{array}$ & --- & $x$ & $x$ \\
\hline Tellina & --- & $x$ & --- & $x$ & $x$ \\
\hline Gastropods: & & & & & \\
\hline Turcicula & $\times$ & ---- & $\times$ & $-\ldots$ & -..- \\
\hline Epitonium & ---- & $x$ & $-\ldots$ & $\times$ & $-\ldots$ \\
\hline Polinices & --- & $x$ & -- & $\times$ & $x$ \\
\hline Turritella & $-\cdots$ & $\hat{x}$ & $-\ldots$ & --- & $\hat{x}$ \\
\hline Echinophoria & --- & $\hat{x}$ & --n & --- & - \\
\hline Gyrineum & --- & $x$ & $\times$ & -- & $\ldots$ \\
\hline Olequahia & ---- & $x$ & - & $x$ & --- \\
\hline Bruclarkia & -n. & $\hat{x}$ & 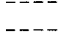 & $\hat{x}$ & $\times$ \\
\hline Cancellaria & ---- & $x$ & $\ldots$ & --- & --- \\
\hline Conus & $\times$ & --- & $\ldots$ & $\ldots$ & $-\ldots$ \\
\hline Exilia & -__- & $\times$ & $-{ }_{-1}$ & $\times$ & $\ldots$ \\
\hline Fulgurofusus & --- & $\hat{x}$ & $\begin{array}{ll}---- \\
----\end{array}$ & - & -- \\
\hline "Gemmula" & $\begin{array}{l}---- \\
----\end{array}$ & $\hat{x}$ & --- & $x$ & 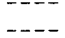 \\
\hline Nekewis & ---- & $x$ & --- & --- & - - - \\
\hline Scaphander & ---- & $x$ & --- & $\times$ & $\times$ \\
\hline
\end{tabular}
sent coast, the depositional-faunal sequence is analogous to that of the Keasey and Pittsburg Bluff Formations in northwestern Oregon.

TABLE 3.-Distribution of molluscan genera in the lower, middle, and upper parts of the Keasey Formation and their occurrence in the Pittsburg Bluff and Eugene Formations [Compiled from Moore and Vokes, 1953, and Hickman, 1969]

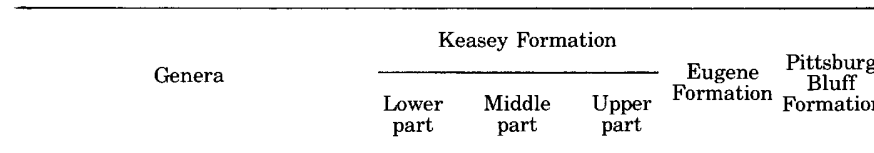


In northwestern Oregon the Keasey Formation, represented by shale, and the Pittsburg Bluff Formation, represented by sandstone, are comformable but have almost no species in common; in southwestern Oregon, the Bastendorff Shale and the Tunnel Point Sandstone are conformable and contain no species in common. In both areas, depth of water is believed to be the controlling factor explaining the abrupt faunal break between early and middle Oligocene formations.

In the Newport area, on the coast of Oregon north of Coos Bay, the Alsea Formation, considered early, middle, and late Oligocene by Snavely, MacLeod, Rau, Addicott, Pearl, and Quinterno (1975), is conformably overlain by the Yaquina Formation (late Oligocene and early Miocene) and unconformably underlain by the Nestucca Formation (late Eocene). The Alsea Formation has yielded 35 species of mollusks (Vokes and others, 1949); and 13 of these also occur in the Pittsburg Bluff Formation. The upper part of the Alsea Formation contains mollusks of provincial late Oligocene age (Warren O. Addicott, written commun., 1973).

The following genera are represented in the Alsea Formation but not in the Pittsburg Bluff Formation:

$\begin{array}{cc}\text { Gastropods } & \text { Pelecypods } \\ \text { Calyptraea } & \text { Lucina } \text { (Here) } \\ \text { Liracassis } & \text { Loxocardium? } \\ \text { Exilia } & \text { Macoma } \\ \text { Ancilla } & \text { Apolymetis }\end{array}$

There are no obvious differences in ecologic requirements between these genera and those in the Pittsburg Bluff Formation.

Two small, poorly preserved molluscan faunas were collected in the Newport area, one of which has been correlated with a fauna from the Gries Ranch Formation, the other with a fauna from the Keasey Formation (Vokes and others, 1949). Further investigation may show that there was a close ecologic relation between the Newport area and the Pittsburg area during early and middle Oligocene time.

\section{SUMMARY}

Many of the genera found in the Keasey Formation are not found in the Pittsburg Fluff Formation. This curious fact can perhaps be explained as a result of differing habitats; the extinction of genera is not involved as most of these genera are still living today. The Keasey fauna lived predominantly in moderately deep water, at depths greater than $50 \mathrm{~m}$, on a bottom of silt, whereas the Pittsburg Bluff fauna lived predominantly in water shallower than $50 \mathrm{~m}$, on a bottom of fine sand. A similar ecologic difference existed near Coos Bay during the deposition of the Bastendorff and Tunnel Point
Formations, equivalent to the Keasey and the Pittsburg Bluff Formations, respectively. The Gries Ranch Formation, a shallow-water equivalent of the upper part of the Keasey Formation, contains 10 Pittsburg Bluff species, a strong indication that ecology is the limiting factor.

The Eugene Formation may have been deposited in an environment in which the elements of the Keasey fauna that could tolerate shallower water, of $50 \mathrm{~m}$ or less, could live.

The first Pacific coast fossils to be assigned to the Oligocene were the mollusks collected by Diller near Pittsburg, Oreg., and later identified by Dall (Diller, 1896, p. 466). Presumably Dall's assignment was based on a comparison of the genera with those of the Oligocene of Europe and on the percentage of living taxa. Dall's first assignment of the Pittsburg Bluff fauna to the Oligocene has been endorsed by most other molluscan specialists, on the basis of comparison at the generic level of its mollusks with those from the Oligocene of the Gulf Coast and of Europe, of superposition, and of the marked change in the molluscan fauna at the end of the Eocene, when many genera disappeared and others made their first appearance.

In 1936 Schenck and Kleinpell proposed the Refugian Stage for part of the Pacific coast Tertiary. They designated as the type locality for this stage Canada de Santa Anita, on the south side of the Santa Ynez Mountains, Santa Barbara County, Calif., about 5 miles west of Gaviota Pass. Schenck and Kleinpell (1936, p. 219) stated that ${ }^{*} * * *$ the Refugian stage comprises the rocks deposited after the strata usually included within the Tejon Formation (restricted) were laid down and before the Zemorrian Stage." They believed that the Refugian Stage is "probably equivalent in age to a portion of the upper Eocene or lower Oligocene series of Europe." They considered it to be represented in Oregon by the Eugene, Pittsburg Bluff, Tunnel Point, Keasey, and Bastendorff Formations, in Washington, by the Lincoln [Lincoln Creek] and Gries Ranch Formations. They also believed that the Refugian Stage included the Acila shumardi Zone and was roughly equivalent, in its type area, to the Turritella variata Zone.

According to Schenck and Kleinpell, the Keasey species Acila (Truncacila) nehalemensis Hanna first appears in the basal part of the Refugian Stage (1936, p. 220-221). The Pittsburg Bluff species Acila (Truncacila) shumardi (Dall), Callista pittsburgensis Dall, Molopophorus gabbi Dall, and Bruclarkia columbiana (Anderson and Martin) make their last appearance in the uppermost part of the Refugian Stage (Schenck and Kleinpell, 1936, p. 221).

Addicott (1972), in a paper on the provincial mollus- 
can stages of the Temblor Range in California, discusses the Refugian Stage (p. 5), calls it early Oligocene (p. 4, fig. 3), and states that the Refugian and Zemorrian Stages in this area are at least in part coeval. He bases this conclusion on the occurrence of the Refugian index species Bruclarkia columbiana in strata that can readily be traced to the lowermost part of the type Zemorrian Stage of Kleinpell (1938).

In 1963 Weaver and Kleinpell published an exhaustive study of foraminiferal and molluscan faunas from the Gaviota and Alegria Formations in the Santa Barbara embayment of California, which contains the type area of the Refugian Stage. One of the most noteworthy provincial correlations made by Weaver and Kleinpell on the basis of foraminifers and mollusks was that of the Bastendorff and Keasey Formations with the middle and upper members of the Gaviota Formation and an implied correlation of the lower 200 feet of the Alegria Formation (the uppermost part of the "Turritella variata Zone") with the Lincoln Creek Formation of Washington and its equivalents, which would include the Pittsburg Bluff Formation (Weaver and Kleinpell, 1963, p. 45).

Weaver and Kleinpell believe that several West Coast formations usually considered to be of early or middle Oligocene age, are on the basis of mollusks, in whole or in part of the same age as the Turritella variata lorenzana Zone of Santa Barbara. These formations are the middle and upper parts of the Bastendorff, the Tunnel Point, the Keasey, the Pittsburg Bluff, the Gries Ranch, and the Lincoln Creek Formations (Weaver and Kleinpell, 1963, p. 113-114). Although they found few molluscan species that are common to the Pacific Northwest and the Santa Ynez Mountains of California, they felt that these few are exceptional in their apparent stratigraphic fidelity. The occurrence of Acila nehalemensis in the upper Gaviota beds of the Santa Ynez Range makes it possible to correlate these beds with the middle and upper Bastendorff and the Keasey Shale. The Lincoln Creek Formation can be correlated with the lower part of the Alegria Formation-the Turritella variata-bearing members A to C. They conclude that the Turritella variata Zone, since it contains 1-2 percent of living species and some giant venericards, is late Eocene and perhaps early Oligocene, and that the Refugian Stage is therefore late Eocene and perhaps very early Oligocene (Weaver and Kleinpell, 1963, p. 118).

Schenck and Kleinpell (1936) defined the Refugian Stage on the basis of its carefully delineated type section, and although they used local first and last appearances of both benthonic foraminifers and mollusks to mark the boundaries, they then did not intend stratigraphic range extensions to change the definition of the stage (p. 221). Although other stages have been defined on the basis of provincial fossil zones, the Refugian was originally intended to be of fixed geologic age-the age of its type section. In recent years the Refugian has taken on more the character of a stage based exclusively on foraminiferal zones. This reduces its usefulness in molluscan paleontology because the provincialism of both benthonic foraminifers and mollusks is measurably significant over the distance from the type locality of the Refugian to, for example, the type locality of the Pittsburg Bluff Formation. Whereas in original concept the Refugian Stage might have had lasting utility in broad-scale West Coast stratigraphy, at this time it seems difficult, if not impossible, to use it judiciously.

The type locality for Acila (Truncacila) shumardi of the Acila shumardi Zone of Schenck (1936) is at the type locality of the Pittsburg Bluff Formation, and the Acila shumardi Zone has been recognized since 1936 in all the Pacific coast states, including Alaska, and has always been assigned to the Oligocene.

Durham (1944) proposed magafaunal zones for the Tertiary of southwestern Washington; one of these was the Molopophorus gabbi Zone. M. gabbi is a common and characteristic species of the Pittsburg Bluff Formation. Presumably because $M$. gabbi is not as widespread geographically in its occurrence as Acila shumardi, the Molopophorus gabbi Zone is not as widely used as the Acila shumardi Zone. The Molopophorus gabbi Zone is, however, roughly equivalent to at least the lower part of the Acila shumardi Zone.

Durham listed as characteristic of the Molopophorus gabbi Zone the species Bruclarkia columbiana, Molopophorus dalli, Perse olympicensis quimpersensis, P. pittsburgensis, and Spisula pittsburgensis; all but Perse olympicensis and Molopophorus dalli occur in the Pittsburg Bluff Formation. Molopophorus dalli, which Durham includes in the Molopophorus gabbi Zone, does not occur at the same horizon as $M$. gabbi in northwestern Oregon; it seems to be an older species, restricted to the early Oligocene.

The position of the provincial Oligocene-Miocene boundary has been in dispute for many years (Moore, 1963, p. 1-2), and complete agreement still has not been reached. The problems concerning the EoceneOligocene boundary seemed to be nearing solution, with generally good agreement, until fairly recent years. In the most extreme example of these recent problems, Eames, Banner, Blow, Clarke, and Cox (1962) published a paper on mid-Tertiary correlation in which they denied that there is Oligocene at all on the western coast of North America.

David Bukry (written commun., 1973) considers a sample from USGS locality M3865, about $100 \mathrm{~m}$ below the top of the Keasey Formation, to be late Eocene or 
earliest Oligocene in age on the basis of the following coccoliths that he was able to identify.

USGS locality M3865. Railroad cut adjacent to State Highway 47, $0.5 \mathrm{~km}$ south of main street of Vernonia, Oreg., at $45^{\circ} 51.3^{\prime}$ N., $123^{\circ} 11.8^{\prime} \mathrm{W}$.

Braarudosphaera bigelowii (Gran and Braarud) Chiasmolithus oamaruensis (Deflandre)

Coccolithus eopelagicus (Bramlette and Riedel) Coccolithus pelagicus (Wallich)

Cyclicargolithus sp., cf. C. floridanus (Roth and Hay)

Dictyococcites bisectus (Hay, Mohler, and Wade)

Dictyococcites scrippsae Bukry and Percival

Isthmolithus recurvus Deflandre

Many authors have cited the difficulties of provincial correlation in the Oligocene. Whereas the Eocene permits fairly easy correlations over wide areas, and the Miocene permits reasonable correlations, the Oligocene has always been troublesome in this respect. The usual explanations for the difficulty with the Oligocene have been (1) that the basins of deposition were isolated and (2) that distinctive Caribbean elements in the Eocene faunas migrated southward in Oligocene time. The problem of precise correlation is further complicated by the fact that since the most useful planktonic species of foraminifers and coccoliths do not commonly occur with the nearshore molluscan faunas either on the Pacific coast or at the European stratotype localities, detailed studies of interfingering of facies are required in both regions. And, the original series and stages in Europe were not as carefully defined as might have been desired (Fischer and others, 1971). However, the age determination by David Bukry given above, based on coccoliths from the middle Keasey as defined by Moore and Vokes (1953, p. 115, fig. 28), provides new evidence from this cosmopolitan planktonic fossil group for a late Eocene and early Oligocene age for the Keasey Formation and its correlatives. On the basis of superposition and its contained fauna, the overlying Pittsburg Bluff Formation is assigned to the middle Oligocene. The sum of all paleontologic and stratigraphic evidence now available indicates that the Pittsburg Bluff Formation is of provincial middle Oligocene age.

\section{CORRELATION}

The marine lower and middle Oligocene sedimentary rocks of the Pacific Northwest range in facies from conglomerate (Gries Ranch Formation) through sandstone (Eugene Formation) and fine-grained sandstone and siltstone (Pittsburg Bluff Formation) to deepwater shale (Keasey Formation). In some areas, such as those around Newport and Eugene, Oreg., depositional conditions during the Oligocene were apparently fairly constant. In other areas, such as those around Pittsburg and Coos Bay, Oreg., an abrupt change took place at the end of the early Oligocene from relatively deepwater to relatively shallow-water deposition as evidenced by both the character of the sedimentation and the fauna.

In the Pacific Northwest, a heavy cover of vegetation, discontinuous exposures, interruption by faults, and the recurrence of similar sediments at various horizons throughout the Tertiary make even local correlation difficult and make regional correlation impossible in unfossiliferous rocks. The Pittsburg Bluff molluscan fauna, however, although small in number of species, is distinctive and it includes some species of short time range that occur as far north as Alaska and as far south as southern California. It therefore permits considerable confidence in provincial correlation.

The distribution of Pittsburg Bluff species in some other formations of late Eocene, Oligocene, and early Miocene age and Pittsburg Bluff species not known to occur outside the Pittsburg Bluff Formation is given in table 4. A total of 48 species of mollusks has been identified in the Pittsburg Bluff; 9 of these are not now known to occur elsewhere. The number of species that occur in other formations with which the Pittsburg Bluff Formation has been precisely or approximately correlated, listed in north to south order, is as follows:

\section{Formation} Number of species

Stepovak Formation of Burk (1965) _..._- 3

Poul Creek Formation _._._. 9

Quimper Sandstone of Durham (1942) _-_ 9

Gries Ranch Formation _._._._. 10

Lincoln Creek Formation _._._._._. 14

Alsea Formation _....... 13

Eugene Formation _.......... 17

Tunnel Point Sandstone _......... 11

San Lorenzo Formation

Wygal Sandstone Member of

Temblor Formation

Cymric Shale Member of

Temblor Formation __. 1

Kirker Tuff

Tumey Formation of Atwill (1935) _..-- 3

San Emigdio Formation _........... 2

Alegria Formation of Dibblee (1950) _.... 1

Of the total number of Pittsburg Bluff species, 28 species, or 58 percent, are known to occur in other formations of middle Oligocene age; 12 species, or 25 percent, occur in early Oligocene formations; and 10 species, or 22 percent, occur in formations assigned to the late Oligocene or early Miocene. Only two species are found in late Eocene formations.

The correlation chart (fig. 7) indicates graphically the 
TABLE 4.-Distribution of Pittsburg Bluff species in some other formations of late Eocene, Oligocene, and early Miocene age

\begin{tabular}{|c|c|c|c|c|c|c|c|c|c|c|c|c|c|c|c|c|}
\hline \multirow[b]{2}{*}{ Species } & \multicolumn{2}{|c|}{ Alaska } & \multicolumn{5}{|c|}{ Washington } & \multicolumn{5}{|c|}{ Oregon. } & \multicolumn{4}{|c|}{ California } \\
\hline & $\begin{array}{c}\text { Stepovak } \\
\text { Formation } \\
\text { of Burke } \\
\text { (1965) }\end{array}$ & $\begin{array}{c}\text { Poul } \\
\text { Creek } \\
\text { Formation }\end{array}$ & $\begin{array}{c}\text { Gries } \\
\text { Ranch } \\
\text { Formation }\end{array}$ & $\begin{array}{c}\text { Quimper } \\
\text { Sandstone } \\
\text { of } \\
\text { Durham } \\
(1942)\end{array}$ & $\begin{array}{c}\text { Marrow- } \\
\text { stone } \\
\text { Shale } \\
\text { of Durham } \\
(1944)\end{array}$ & $\begin{array}{c}\text { Lincoln } \\
\text { Creek } \\
\text { Formation }\end{array}$ & $\mid \begin{array}{c}\text { Blakeley } \\
\text { Formation } \\
\text { of Weaver } \\
\text { (1912) }\end{array}$ & $\begin{array}{c}\text { Keasey } \\
\text { Formation }\end{array}$ & $\begin{array}{c}\text { Alsea } \\
\text { Formation }\end{array}$ & $\begin{array}{c}\text { Eugene } \\
\text { Formation }\end{array}$ & $\left|\begin{array}{c}\text { Tunnel } \\
\text { Point } \\
\text { Formation }\end{array}\right|$ & $\mid$\begin{tabular}{|l} 
Scappoose \\
Formation
\end{tabular} & $\underset{\substack{\text { San } \\
\text { Lorenzo } \\
\text { Formation }}}{\mid}$ & \begin{tabular}{|c|} 
Cymric \\
Shale \\
Memberof \\
Temblor \\
Formation
\end{tabular} & \begin{tabular}{|c|} 
Wygal \\
Sandstone \\
Member of \\
Temblor \\
Formation
\end{tabular} & $\begin{array}{c}\text { Tumey } \\
\text { Formation } \\
\text { of Atwill } \\
\text { (1935) }\end{array}$ \\
\hline $\begin{array}{l}\text { Gastropods: } \\
\text { architectonico }\end{array}$ & & & & & & & & & & & & & & & & \\
\hline $\begin{array}{l}\text { Architectonica blanda Dall } \\
\text { Turritella pittsburgensis, } \mathrm{n} . \mathrm{sp} \text {. }\end{array}$ & & $-\cdots$ & ---- & $-\cdots$ & --- & --- & --- & - & --- & ---- & --- & $x$ & --- & -.-- & ---- & --- \\
\hline $\begin{array}{l}\text { Turritella pittsburgensis, n. sp. } \\
\text { Opalia (Dentiscala? hertleini, n. } \mathrm{sp} .\end{array}$ & $\cdots$ & --- & ---- & $\cdots$ & $\cdots$ & $\cdots$ & --- & $\therefore$ & $\cdots$ & --- & $\cdots$ & $\cdots$ & -.- & --.- & ---- & -.-- \\
\hline $\begin{array}{l}\text { Crepidula pileum (Gabb) } \\
\text { Cryntonatica nittshurgognis o }\end{array}$ & ---- & $-\cdots$ & $\times$ & --- & -.-- & --- & -.-- & $-\cdots$ & ---- & $\ldots$ & $\cdots$ & ---- & ---- & --- & -.-- & ---- \\
\hline $\begin{array}{l}\text { Cryptonatitca phttsurbensils, n. ps. } \\
\text { Polinices washingtonensis (Weaver) }\end{array}$ & $---\cdot$ & $\cdots$ & $x$ & $-x$ & $\cdots$ & $-x^{-1}$ & $x$ & $\cdots$ & $x$ & $x$ & $x$ & $\cdots$ & $\cdots$ & -.- & --.- & $\cdots$ \\
\hline Neverita (Glossaulax) thomsonae Hickman & .... & ---- & --- & --- & .... & -.. & $\cdots$ & ---- & ---- & $\times$ & --- & --- & $-\cdots$ & --- & $\times$ & $-\cdots$ \\
\hline $\begin{array}{l}\text { Eosiphonalia oregonensis (Dall) } \\
\text { Buclarkia columbiana (Anderson and Martin) }\end{array}$ & --- & 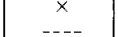 & $-\cdots$ & $x$ & $x$ & $x$ & $-\cdots$ & $\ldots$ & $\stackrel{?}{x}$ & $-x$ & $-x$ & --.- & --.- & $x$ & $-\cdots$ & $-\cdots-$ \\
\hline Molopophorus gabbi Dall & $\cdots$ & $-\cdots$ & $\ldots$ & $\times$ & ---- & $x$ & --- & $-\ldots$ & $-\cdots$ & --- & $x$ & --- & $x$ & --- & --- & $\ldots$ \\
\hline $\begin{array}{l}\text { Priscof usus stewarti (Tegland) } \\
\text { Perse pitsbyrensis Durham }\end{array}$ & ---- & $\mathrm{x}$ & --- & $-\cdots$ & 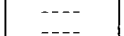 & ...- & $\times$ & $-\cdots$ & $-x^{--}$ & $\cdots$ & $-\ldots$ & $\cdots$ & $\cdots$ & ---- & $-\cdots$ & $-\cdots$ \\
\hline Perse pittsburgensis vernoniensis, $\mathbf{n}$. subsp....- & -.-- & --.- & ---- & --- & ---- & $-\cdots-$ & --- & 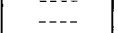 & ...- & $\cdots$ & -... & --- & ---- & ---- & $\cdots$ & -..- \\
\hline Aforia campbelli Durham & -..- & --- & --- & --- & $\ldots$ & $\times$ & --- & -..- & -.- & $-\ldots$ & --- & -..- & --- & --- & --- & $\cdots$ \\
\hline $\begin{array}{l}\text { Taranis columbiana (Anderson and Martin) } \\
\text { Sniratropis bincaidi (Weaver) }\end{array}$ & $-\cdots$ & $\cdots-$ & 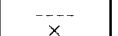 & --- & --- & $-\bar{x}$ & $\cdots$ & $-\cdots$ & $\ldots$ & $-\cdots$ & $-\bar{x}$ & --- & -.- & --- & $\cdots$ & --- \\
\hline $\begin{array}{l}\text { Spirotropis kincaidi (Weaver) } \\
\text { Suavodrillia winlockensis (Effinger) }\end{array}$ & $-\cdots$ & -..- & $\hat{x}$ & ---- & ---- & --- & ---- & $\cdots-$ & ---- & ---- & -.-- & - & ---- & $\ldots$ & $-\cdots-$ & $\cdots$ \\
\hline Odostomia winlockiana Effinger & $-\ldots$ & --- & $x$ & -- & $-\ldots$ & $\cdots$ & 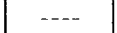 & --- & --- & --- & --- & -..- & $\ldots$ & --- & --- & 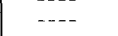 \\
\hline $\begin{array}{l}\text { Acteon chehalisensis (Weaver) } \\
\text { Scaphander stewarti Durham }\end{array}$ & & $-\cdots$ & $x$ & $x$ & --- & $\begin{array}{c}x \\
---\end{array}$ & $-\cdots$ & $x$ & $-\cdots$ & $x$ & $\begin{array}{ll}---- \\
----\end{array}$ & --- & $-\cdots$ & $-\cdots$ & $\begin{array}{ll}--- \\
---\end{array}$ & $-\cdots$ \\
\hline $\begin{array}{l}\text { Scaphopod: } \\
\text { Dentalium (Fissidentalium?) laneensis Hickman }\end{array}$ & $\ldots$ & - & $\ldots$ & - & ---- & -.- & $\ldots$ & --- & --- & $\times$ & - & $\cdots$ & - & - & $x$ & -.. \\
\hline Pelecypods: & & & & & & & & & & & & & & & & \\
\hline $\begin{array}{l}\text { Nucula (Leionucula) vokesi, } \mathrm{n} . \mathrm{sp} \\
\text { Acila (Truncacila) shumardi (Dall) }\end{array}$ & $x$ & $x$ & $x$ & $\cdots$ & $\cdots$ & $x$ & $-\cdots-$ & $-\cdots$ & $x$ & $x$ & $x$ & $\cdots$ & $\cdots$ & $\cdots$ & $\cdots$ & $x$ \\
\hline $\begin{array}{l}\text { Litorhadia washingtonensis (Weaver) } \\
\text { Yldial) }\end{array}$ & --- & $-\cdots$ & $\times$ & $x$ & ---- & $\stackrel{x}{x}$ & $x$ & --- & $x$ & $x_{x}^{x}$ & $\times$ & $\cdots$ & $\times$ & --- & $-\cdots$ & $--\cdot$ \\
\hline $\begin{array}{l}\text { Yoldia (Kalayoldia) oregona (Shumard) } \\
\text { Crenella porterensis Weaver }\end{array}$ & $\cdots$ & $x$ & $\cdots--$ & $\ldots$ & $-\cdots$ & $\begin{array}{l}x \\
x\end{array}$ & $-\bar{x}$ & $-x^{-}$ & $x$ & $x$ & $-\cdots$ & $\ldots$ & $-\cdots$ & $-\cdots$ & ---- & $-\cdots$ \\
\hline Lucinoma columbiana (Clark and Arnold) & --- & -.-- &.-- & -.-- & -.-- &.-- & $x$ & ---- & --- & $\cdots$ & $-\cdots$ & --- & $\cdots$ & $-\ldots$ & --- & $-\ldots$ \\
\hline Felaniella (Felaniella) snavelyi, n. sp. & 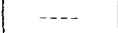 & 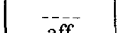 & $-\cdots$ & $\cdots$ & --- & $x$ & $-\cdots$ & $-x-$ & $-\cdots-$ & $-1-$ & --- & $\cdots$ & ---- & --- & ---- & --- \\
\hline $\begin{array}{l}\text { Nemocardium (Keenaea) lorenzanum (Arnold) } \\
\text { Pitar (Pitar) dalli (Weaver) }\end{array}$ & ---- & $\stackrel{\mathrm{m}}{\times}$ & $\cdots$ & $\cdots$ & $x$ & $x$ & $\hat{\ldots}$ & $\hat{n}$ & $\begin{array}{l}x \\
x\end{array}$ & $\begin{array}{l}x \\
x\end{array}$ & $x$ & $\cdots$ & $x^{x}$ & $\cdots$ & --- & $x$ \\
\hline Callista (Macrocallista) pittsburgensis Dall & 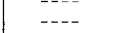 & $x$ & ---- & --- & ---- & $x$ & $\cdots-$ & --- & $\times$ & $x$ & $\times$ &.--- & $-\ldots$ & -..- &.--- & ---- \\
\hline Spisula (Mactromeris) pittsburgensis Clark & $-\ldots$ & $x$ & $-\ldots$ & $x$ & $\cdots$ & ...- & $x$ & --- & $x$ & $\times$ & $\stackrel{x}{x}$ & --- & --- & --- & --- & $-\cdots$ \\
\hline actromeris? i veneriformis Clark & --- & ---- & $\cdots$ & --- & ---- & $\cdots$ & ---- & $\cdots$ & --- & --- & $\times$ & $\cdots$ & ---- & ---- & ---- & ---- \\
\hline $\begin{array}{l}\text { Ervilia oregonensis Dalluna } \\
\text { Tellina (Eurytellina) aducanasa Hickman -- }\end{array}$ & -..- & - & $\ldots$ & - & --- & $-\ldots$ & --- & $-\cdots$ & $-\cdots$ & $x$ & $-\ldots-$ & --.- & -..- & -..- & --- & --.- \\
\hline Tellina? pittsburgensis Clark & -..- & aff. & $\times$ & $x$ & $\cdots$ & --- & $\cdots$ & $\cdots$ & $-\ldots$ & $x$ & $\times$ &.-- & ---- & ---- & $\cdots$ & $x$ \\
\hline Solen townsend & $\cdots$ & aff & $\times$ & 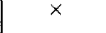 & $-\cdots$ & $x$ & --- & $-\cdots$ & $\underset{c f}{x}$ & $-\bar{x}$ & --- & $\cdots$ & --- & --- & --- & $-\cdots$ \\
\hline $\begin{array}{l}\text { Solena }(\text { Eosolen) eugenensis (Clark) } \\
\text { Panopea snohomishensis Clark }\end{array}$ & $\ldots$ & $\begin{array}{l}\text { cf. } \\
\text { cf. }\end{array}$ & $\cdots$ & $\cdots$ & $-\cdots$ & $\ldots$ & $\cdots$ & -.- & 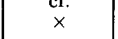 & $x$ & -..- & -.-- & $\cdots$ & $-\cdots$ & $\cdots$ & $\cdots$ \\
\hline Panopea ramonensis Clark - & --- & $x$ & $\cdots$ & $\cdots$ & $\cdots$ & --- & $\underset{x}{x}$ & ---- & - & $x$ & --- & --- & --- & --- & $\times$ & --- \\
\hline $\begin{array}{l}\text { Cochlodesma bainbridgensis Clark } \\
\text { Thracia (Thracia) condoni Dall }\end{array}$ & $\stackrel{x}{x}$ & $\begin{array}{l}x \\
x\end{array}$ & $\cdots$ & $x$ & $\cdots$ & $\ldots$ & -..- & ---- & $\underset{x}{\text { arI. }}$ & $x$ & $-\cdots$ & $\cdots$ & $-x$ & $--\cdot$ & $-\cdots$ & $-\cdots$ \\
\hline
\end{tabular}




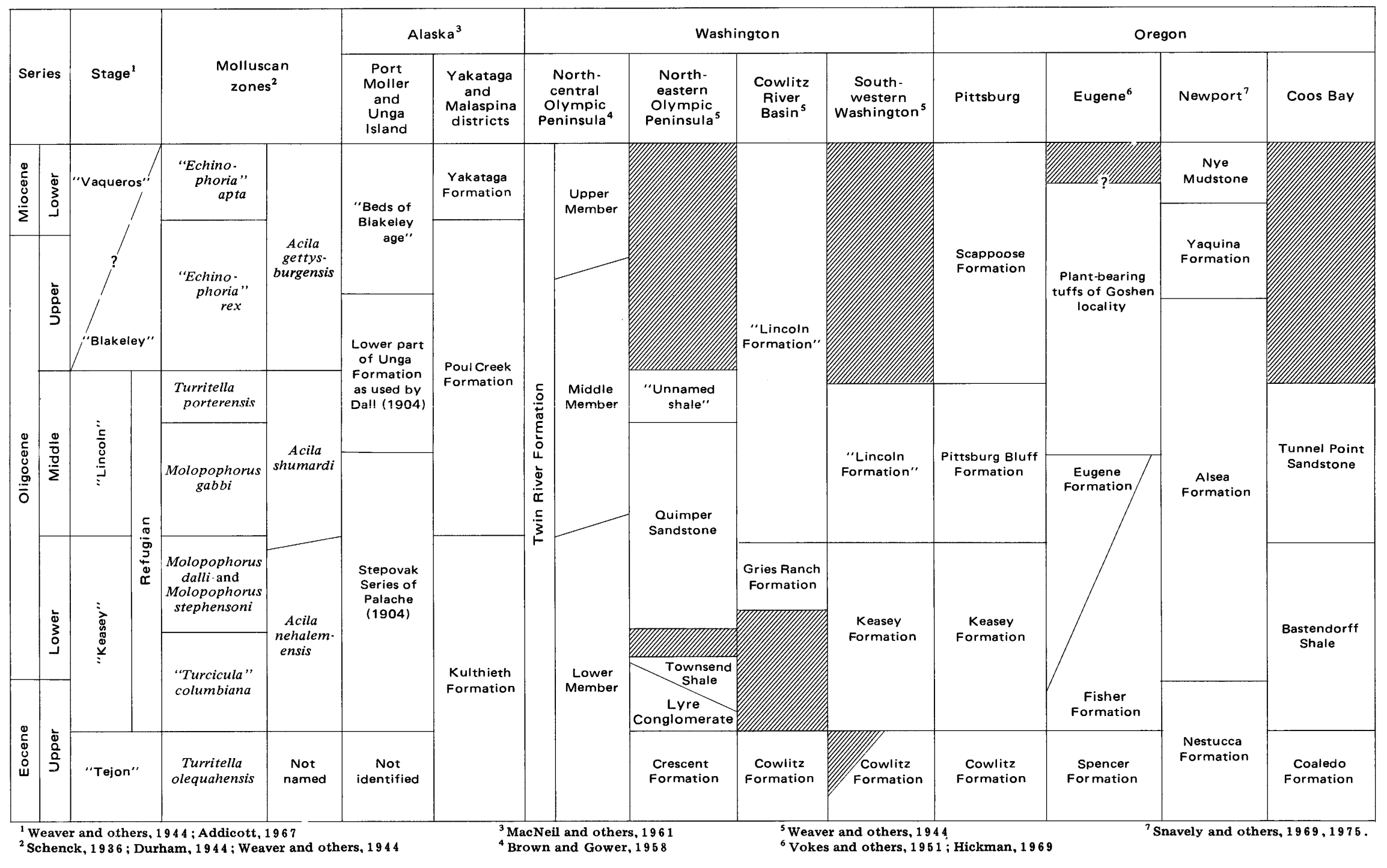

FIGURE 7.-Correlation chart of selected middle Tertiary stratigraphic units in Alaska, Washington, and Oregon. 
formations believed to be correlative entirely or in part with the Pittsburg Bluff Formation. Pittsburg Bluff molluscan species are most abundant in the Tunnel Point Sandstone at Coos Bay, the upper part of the Eugene Formation in the Willamette Valley, and the Alsea Formation near Newport, Oreg. Other probable time-stratigraphic equivalents of the Pittsburg Bluff Formation on the basis of mutual occurrence of species are: parts of the Stepovak Formation of Burke (1965) and Poul Creek Formation in Alaska, the Lincoln Creek Formation and Quimper Sandstone of Durham (1942) of Washington, and the Wheatland Formation of Clark and Anderson (1938), Tumey Formation of Atwill (1935), San Emigdio Formation, Wygal Sandstone and Cymric Shale Members of the Temblor Formation, Alegria Formation of Dibblee (1950), and Kirker and San Lorenzo Formations of California.

A mixture of Keasey and Pittsburg Bluff species occurs throughout the Eugene Formation, as pointed out in the section on ecology; some typical Pittsburg Bluff species such as Callista pittsburgensis, Acila shumardi, and Bruclarkia columbianum occur only in its upper part. Table 5 gives all the Oligocene species that were found high in the Eugene Formation by Hickman (1969, p. 16-19).

TABLE 5.-Checklist of Oligocene mollusks in the upper part of the Eugene Formation in Oregon [Locality numbers and occurrence are from Hickman (1969)]

\begin{tabular}{|c|c|c|c|c|c|c|c|c|c|c|}
\hline \multirow{2}{*}{ Locality No. } & \multicolumn{5}{|c|}{ Eugene area } & \multicolumn{5}{|c|}{ Salem area } \\
\hline & 12 & 28 & 34 & 35 & 39 & 41 & 42 & 44 & 46 & 47 \\
\hline $\begin{array}{c}\text { Pelecypods } \\
\text { Acila (Truncacila) nehalemensis (G }\end{array}$ & & & & & & & & & & \\
\hline Acila (Truncacila) nehalemensis & & & -- & -- & -- & -- & & -- & $x$ & \\
\hline minima Hickman & $\times$ & $\times$ & -- & - & -- & -- & -- & -- & -- & -- \\
\hline $\begin{array}{l}\text { Acila (Truncacila) shumardi (Dall) } \\
\text { Nuculana washingtonensis }\end{array}$ & -- & -- & -- & $\times$ & $x$ & $x$ & $\times$ & $x$ & -- & -- \\
\hline (Weaver) & $\times$ & $\times$ & -- & -- & -- & - & $x$ & $x$ & -- & -- \\
\hline $\begin{array}{l}\text { Yoldia (Kalayoldia) oregona } \\
\text { (Shumard) }\end{array}$ & & $\times$ & -- & -- & .- & $x$ & $x$ & - - & -- & $\ldots$ \\
\hline Modiolus eugenensis Clark & $x$ & $\times$ & -- & - & - & -- & -- & -- & -- & -- \\
\hline Mytilus snohomishensis Weaver _- & .- & -- & -- & - & -. & -- & $x$ & $\ldots$ & -- & -- \\
\hline Parvicardium eugenense (Clark) -- & $x$ & $x$ & $x$ & $\times$ & $x$ & -- & $x$ & -- & $\times$ & - \\
\hline Lucinoma acutilineata (Conrad) - & - & -- & - & $\ldots$ & -- & $\times$ & -- & - & -- & -- \\
\hline Diplodonta parilis (Conrad) & $x$ & $x$ & -- & $\times$ & -. & $\times$ & $x$ & -- & $x$ & $x$ \\
\hline Callista pittsburgensis (Dall) & $x$ & -- & $x$ & $x$ & -- & - & $x$ & -- & $x$ & - \\
\hline Callista n. sp. & $x$ & $\times$ & -- & $\times$ & -- & - & - & - & -- & - \\
\hline Pitar (Pitar) dalli (Weaver) & $x$ & $\times$ & $x$ & $\times$ & $x$ & -- & $x$ & -- & $\times$ & -- \\
\hline Pitar (Pitar) n. sp.? & $x$ & $x$ & - & -1 & -- & -- & - & - & -- & - \\
\hline $\begin{array}{l}\text { Pitar (Lamelliconcha) clarki } \\
\text { (Dickerson) }\end{array}$ & & & & & & & & & & \\
\hline Spisula pittsburgensis Clark & - & $\begin{array}{c}x \\
--\end{array}$ & - & $\ldots$ & - & - & $x$ & $x$ & & \\
\hline Spisula eugenensis (Clark) & $x$ & $\times$ & $x$ & $\times$ & -- & -- & -- & - - & -. & \\
\hline Pseudocardium sp. & -- & $x$ & $x$ & - & -- & - & - & -- & - & $\times$ \\
\hline Tellina pittsburgensis Clark & $x$ & $x$ & -- & & -. & - & - & $x$ & $x$ & - \\
\hline Tellina aduncanasa Hickman & -- & $x$ & -- & & 1 & -- & $x$ & $\times$ & -- & \\
\hline
\end{tabular}

TABLE 5.-Checklist of Oligocene mollusks in the upper part of the Eugene Formation in Oregon-Continued

Locality No. $\quad$ Eugene area Salem area

Pelecypods-Continued

Tellina? n. sp.

Tellina eugenia Dall

Tellina (Moerella) lincolnensis

(Weaver)

Macoma aff. M. inquinata (De-

shayes)
Macoma (Heteromacoma) van-

couverensis (Clark and Anderson) $\times \times \times$

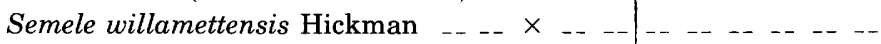

Solena (Eosolen) eugenensis (Clark) $\times \times \times \times \times-\ldots \times \times \times$

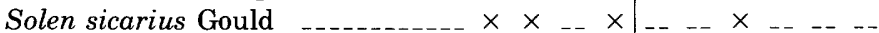

Mya (Arenomya?) kusiroensis

Panopea (Panopea) ramonensis

Clark

Opertochasma turnerae (Hickman)

Martesia sp.

Pandora (Pandora) laevis Hickman

Thracia condoni Dall

Dentalium $\quad$ Scaphopod

$$
\text { Gastropods }
$$

Epitonium (Boreoscala) condoni

(Dall)

E. (B.) condoni oregonensis Durham

$E$. (B.) condoni eugenense Durham

Acrilla (Ferminoscala) dickersoni

Durham

A. $(F$.) becki Durham

Calyptraea diegoana (Conrad)

Calyptraea sookensis Clark and Arnold

Crepidula ungana Dall

Natica (Natica) n. sp.?

Neverita thomsonae Hickman _... $\times \times \ldots \ldots+\ldots$

Polinices washingtonensis (Weaver)

Sinum obliquum (Gabb)

Ficus modesta $\_$(Conrad)

Olequahia schencki Durham

Molopophorus dalli Anderson and Martin

Molopophorus fishii (Gabb)

Bruclarkia vokesi Hickman

Bruclarkia columbiana (Anderson and Martin)

Perse lincolnensis (Van Winkle) -

Exilia lincolnensis (Weaver)

Gemmula bentsonae Durham.

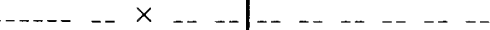

Scaphander stewarti Durham _..-

The presence of such typical Keasey species as Acila (Truncacila) nehalemensis and Olequahia schencki high in the Eugene Formation, combined with the absence of 
any typical Keasey species in the Pittsburg Bluff Formation, might permit considering the hypothesis that all of the Eugene Formation is slightly older than the Pittsburg Bluff Formation. Since the uppermost part of the Eugene Formation and the lower part of the Pittsburg Bluff Formation contain 19 species in common, they are regarded as partly coeval.

\section{SYSTEMATIC DESCRIPTIONS}

$$
\begin{gathered}
\text { Phylum MOLLUSCA } \\
\text { Class GASTROPODA } \\
\text { Family TROCHIDAE } \\
\text { Unidentified trochid? } \\
\text { Plate } 1 \text {, figures } 6,7
\end{gathered}
$$

This single specimen resembles the trochid Bathybembix in overall outline (USNM 213948). Some characteristics of the specimen recall "Turcicula" columbiana Dall (1909, p. 100, pl. 3, figs. 2, 11) that occurs in the Keasey Formation (late Eocene and early Oligocene) in Oregon and has been assigned to Bathybembix by Rehder (1955, p. 255). This specimen does not have so high a spire as Bathybembix, is a much smaller form, and measures $24 \mathrm{~mm}$ in maximum diameter. Patches of the inner shell layers are preserved, as are fairly large nodes on the periphery of the last whorl. The aperture and umbilicus are not preserved.

Locality._USGS 15312.

\section{Family ARCHITECTONICIDAE \\ Genus Architectonica Röding}

Architectonica Röding, 1798, Museum boltenianum, pt. 2, p. 78.

Type species.-By subsequent designation (Gray, 1847, Zool. Soc. London Proc., pt. 15, p. 151) Trochus perspectivus Linné. Holocene, tropical western Pacific Ocean.

\section{Architectonica blanda Dall}

Plate 1, figures 1-4

Architectonica blanda Dall, 1909, U.S. Geol. Survey Prof. Paper 59, p. 80-81, pl. 3, figs. 4, 5. Weaver, 1942, Washington Univ. (Seattle) Pubs. Geology, v. 5, p. 364, pl. 73, fig. 7.

Two incomplete specimens of Architectonica blanda are in the collections. They are distinguished by the smoothness of the spire and by the paired spirals on the periphery of the body whorl. These paired spirals are of equal weight on one specimen and of unequal weight on the other; the more posterior spiral is narrower. According to Dall (1909, p. 80), A. blanda has one strong spiral and one much weaker one. Four somewhat unequally spaced spiral grooves are visible on the base of the shell. Because the umbilicus and umbilical margin are worn and corroded on the specimens at hand and are covered by matrix on the type specimen of the species, an assignment refined to subgenus has not been made.
Holotype.-USNM 107414. Figured specimens: USNM 213945, 213946.

Type locality.-USGS 2697, north fork of Scappoose Creek, at the mouth of Fall Creek, Columbia County, Oreg. Scappoose Formation (late Oligocene and early Miocene).

$A$. blanda is the only post-Eocene species of $A r$ chitectonica reported from Oregon and Washington. Although the type locality has been cited as middle Oligocene (Weaver, 1942, p. 364), it is actually in the Scappoose Formation of late Oligocene and early Miocene age.

Localities._USGS 15588, M3858.

Occurrence elsewhere.-Scappoose Formation (late Oligocene and early Miocene), Oregon.

\section{Family TURRITELLIDAE}

Genus Turritella Lamarck

Turritella Lamarck, 1799, Soc. Hist. Nat. Paris Mém., ser. 1, p. 74.

Type species.-By monotypy Turbo terebra Linné. Holocene, tropical western Pacific Ocean.

Turritella pittsburgensis, n. sp.

Plate 3, figures 11-16; figure 8

Turritella pittsburgensis is a small species (largest specimen, incomplete, $32 \mathrm{~mm}$ high and $10 \mathrm{~mm}$ wide) with a shell of moderate thickness consisting of probably 12 whorls. On the whorls of the spire, the two anterior spiral ribs are the most prominent, and the anterior space between them and the suture is deeply concave. These paired ribs are equal in weight on the spire, but the anterior rib becomes more prominent on the larger whorls nearest the body whorl. Above the paired spirals are two spirals of equal weight, and above them are two of lesser width just below the suture. These two finest spirals are absent on the early whorls of the spire. On the very earliest whorls, only the paired primary spirals and one secondary spiral are present; these spirals strongly suggest relationship to the bicostate Turritella uvasana stock of Merriam (1941, p. 42-44). On one specimen (pl. 3, fig. 14), a fine spiral is present between the paired anterior spirals on the largest preserved whorl. The body whorl is not preserved on the available specimens. The growth-line sinus is shown in figure 8; this deep antispiral sinus has the maximum swelling just above the whorl middle and no apparent growth-line angle. In this regard it resembles Turritella porterensis Weaver from the Lincoln Creek Formation (Eocene to Miocene) of Washington and Turritella oregonensis Conrad from the Astoria Formation (Miocene) of Oregon. Both of these species are assigned to the Turritella uvasana stock by Merriam (1941, p. 43).

Holotype.-Herewith designated USNM 213991, plate 3 , figure 16 . 


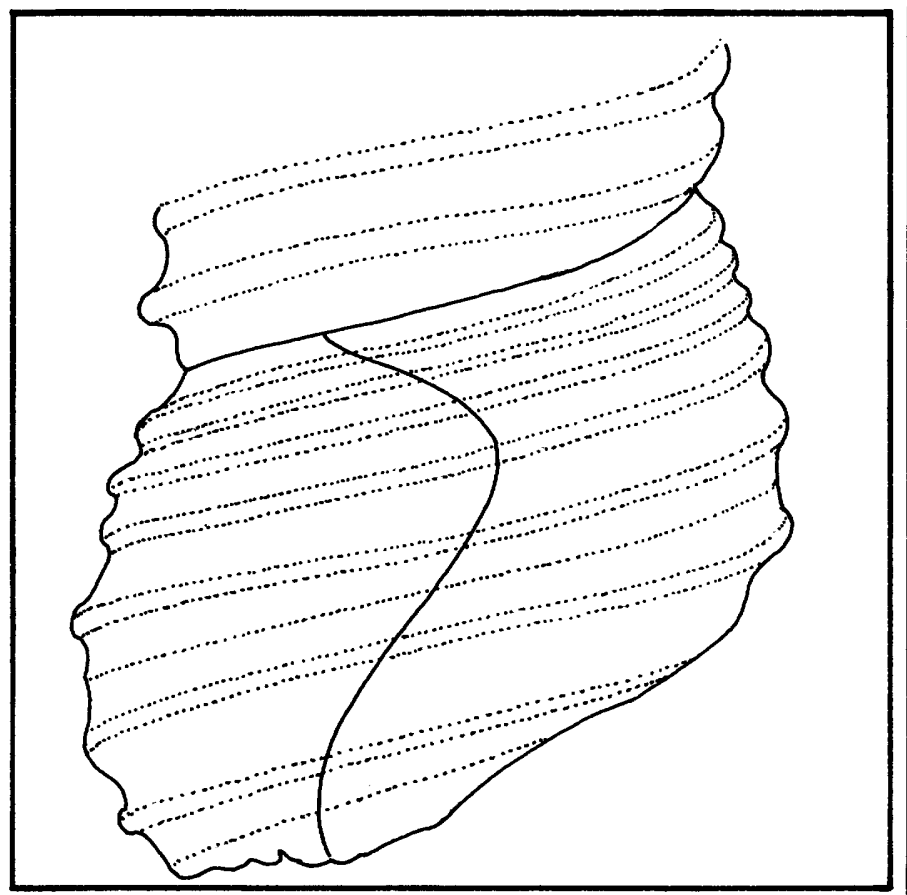

FIGURE 8.-Growth-line sinus on Turritella pittsburgensis, n. sp. Drawing by Anthony D'Attilio.

Type locality.-USGS 15588. Roadcut on logging road along the headwaters of the second main tributary entering Coal Creek from the northeast of its junction with Pebble Creek. 3,900 feet west of grid 820 and 5,200 feet south of grid 2,650, Vernonia quadrangle, Pittsburg Bluff Formation (middle Oligocene), Oregon.

Turritella wheatlandensis Clark and Anderson (1938, p. 949, pl. 3, figs. 10, 18) from the Wheatland Formation (late Eocene or early Oligocene), California, is a much larger species (holotype $59 \mathrm{~mm}$ high, incomplete, and 24 $\mathrm{mm}$ wide) with a heavy shell. $T$. wheatlandensis has four spiral ribs on the adult whorls whereas $T$. pittsburgensis has six. Although both forms have paired anterior ribs that are strongest, the paired spirals are stronger on $T$. wheatlandensis in relation to the other spirals than on $T$. pittsburgensis.

Turritella oregonensis Conrad from the Astoria Formation (Miocene), Oreg. (Moore, 1963, p. 25, pl. 1 figs. 9-12), is similar in size and shell thickness to $T$. pittsburgensis. It also has prominent paired spirals anterior to the middle of the whorl. The paired spirals are, however, more prominent and bolder than on $T$. pittsburgensis and occupy a somewhat more posterior position. $T$. oregonensis has a total of no more than four spirals, whereas $T$. pittsburgensis has six on the later whorls.

Turritella porterensis Weaver from the Lincoln Creek Formation (late Eocene to early Miocene) of Washington does not have the two strong paired anterior ribs, although it does have a pair of primaries with a secondary between them. It has more spiral ribs, and the whorls are gently and almost evenly rounded.

Perhaps Turritella wheatlandensis, T. pittsburgensis, and $T$. oregonensis could appropriately be assigned to one branch of the $T$. uvasana stock and $T$. porterensis and $T$. diversilineata blakeleyensis Weaver (1912, p. 72, pl. 11, fig. 85; pl. 6, figs. 64, 67) from the Blakeley Formation of Weaver (1912) (late Oligocene or early Miocene) in Washington, could be assigned to another separate branch (Merriam, 1941, p. 43, fig. 6).

Localities-USGS 15278, 15457, 15499, 15519, 15530, 15537, 15588, M3873.

Occurrence elsewhere-One poorly preserved specimen from the top of the Keasey Formation (late Eocene and early Oligocene), near Vernonia, Oreg., may be this species (M3864).

\section{Genus Opalia Adams and Adams}

Opalia Adams and Adams, 1853, The genera of Recent Mollusca, v. 1, p. 223.

Type species.-By subsequent designation (Cossmann, 1912, Essais de paleoconchologie comparée, v. 9, p. 78), Scalaria australis Lamarck. Holocene, Australia.

\section{Subgenus Dentiscala de Boury}

Dentiscala de Boury, 1886, Monographie des Scalidae vivante et fossiles, I, pt. 1, p. xxi.

Type species.-By monotypy, Turbo crenata Linné, 1758, Syst. Nat., p. 765. Holocene, Mediterranean and Atlantic.

Opalia (Dentiscala?) hertleini, n. sp. Plate 3 , figures $6,8,20$

This species is of moderate size with a fairly thick shell. It has 12 strong, slightly arcuate axial ribs on the last preserved whorl and about 28 spiral threads. The axial ribs may be offset at the suture or may be confluent. No callus is present. The interspaces are wider than the axial ribs. The spiral threads are of unequal weight, closely spaced, and cross the axial ribs. The spiral threads are microscopically sculptured by axial threads that produce a finely reticulate pattern on well-preserved portions of shell. The suture is impressed, somewhat overlapping, and sinuous. The aperture is not preserved. It has not been possible to determine the presence or character of a basal disk.

Holotype.-Herewith designated USNM 213983, plate 3 , figure 20 .

Type locality._USGS 15588. Cut in logging road along the headwaters of the second main tributary entering Coal Creek from the northeast of its junction with Pebble Creek. 3,900 feet west of grid 820 and 5,200 feet south of grid 2,650, Vernonia quadrangle, Pittsburg Bluff Formation (middle Oligocene), Oregon.

This species most closely resembles the subgenus Dentiscala in configuration and primary sculpture. However, no punctations were seen on the shell, only 
small preserved patches of microscopically reticulate sculpture. Since the outermost shell layer is known to be porous and to decorticate readily, it may be that the punctations are absent owing to lack of preservation of this layer.

The only west coast fossil epitonid which this form at all resembles is Epitonium (Boreoscala) keaseyense Durham (1937, p. 498, pl. 57, fig. 17). It is distinguished from $E$. (B.) keaseyense by its lack of a callus at the suture where the axial ribs are joined and in having more axial ribs and many more spiral threads than $E$. (B.) keaseyense. Opalia (Dentiscala?) hertleini resembles the living form Opalia colimana (Hertlein and Strong) which occurs from Santa Cruz, Nayarit, to Manzanillo, Colima, Mexico (Keen, 1971, p. 438). It differs from it in having two to four more ribs that are smaller than those on $O$. colimana.

Living species in tropical west America are found from southern California and the Gulf of California to Panama (Keen, 1971, p. 438-440).

Localities._USGS 15588, 21612 , M3857.

\section{Family CALYPTRAEIDAE}

Genus Crepidula Lamarck

Crepidula Lamarck, 1799, Soc. Hist. Nat. Paris Mém., p. 78.

Type species.-By monotypy, Patella fornicata Linné. Holocene, Atlantic and Gulf coasts of the United States.

\section{Crepidula pileum (Gabb)}

Plate 1, figures 5,8

Crypta (Spirocrypta) pileum Gabb, 1864, Geol. Survey California, Paleontology, v. 1, p. 137, 228, pl. 29, figs. 2, 3.

Crepidula pileum (Gabb). Stewart, 1926, Acad. Nat. Sci. Philadelphia Proc., v. 78, p. 341-342, pl. 29, figs. 2, 3. Turner, 1938, Geol. Soc. America Spec. Paper 10, p. 90, pl. 20, fig. 6. Effiinger, 1938, Jour. Paleontology, v. 12, p. 378.

Crepidula (Spirocrypta) pileum (Gabb). Clark, 1938, Geol. Soc. America Bull., v. 49, p. 701-702, pl. 4, fig. 19.

Crepidula pileum is a small species. The apex is low and does not rise above the shell. The shell is smooth except for bunched concentric lines. The internal deck is attached along the margins at about the middle of the shell with a sinuous free margin. Because part of the internal deck is missing on the figured specimen, the S-shaped outline of the free deck edge does not show. I am indebted to Bruce Welton, Portland State University, who collected and donated the figured specimen. It is the only well-preserved Crepidula in the collections; the others are poorly preserved or broken.

Lectotype.-ANSP 4221 (Stewart, 1926, pl. 29, fig. 3).

Type locality. - Tejon Pass, Kern County, Calif. (Tejon Formation, early, middle, and late Eocene.)

Crepidula pileum is distinguished from other species of Crepidula by its small size, low apex, and sinuous internal deck margin.

Localities._USGS 15264, 15310, 15310d; figured specimen from road cut on the Vernonia-Scappoose

road, approximately 2 miles from the junction with State Highway 47. Pittsburg Bluff Formation.

Occurrence elsewhere.-Cowlitz Formation (late Eocene) and Gries Ranch Formation (early Oligocene), Washington; Coaledo Formation (late Eocene), Oregon; Tejon Formation (early, middle and late Eocene), California.

\section{Family NATICIDAE Subfamily NATICINAE Genus Cryptonatica Dall}

Cryptonatica Dall, 1892 (1890-1903), Wagner Free Inst. Sci. Trans., v. 3 , pt. 2 , p. 362 .

Type species.-By subsequent designation (Dall, 1909, p. 85), Natica clausa Broderip and Sowerby. Holocene, Arctic Ocean to Queen Charlotte Islands.

Dall proposed Cryptonatica for species with a smooth calcareous operculum and an umbilicus entirely filled with callus. Tectonatica is generally used for a small tropical species (Type: Natica tectula Bonelli) and Cryptonatica for a large boreal species. Another criterion that has been used for distinguishing the shells of the two forms is that the umbilical callus of the type species of Tectonatica does not completely fill the umbilicus (Woodring, 1957, p. 88), whereas in Cryptonatica clausa it does. In the fossil species Cryptonatica oregonensis (Conrad) from the Astoria Formation of Oregon, specimens are found representing both types of umbilical closure (Moore, 1963, pl. 2, figs. 2, 16).

Cryptonatica pittsburgensis $\mathbf{n}$. sp.

Plate 1, figures 9, 12,13,15, 16, 18, 19, 23

Cryptonatica pittsburgensis is small to moderate in size (largest specimen: $28 \mathrm{~mm}$ high, $23 \mathrm{~mm}$ wide); most of the specimens are small. The umbilicus is usually completely filled with callus (pl. 1, fig. 13) but there are rare specimens which have a slight groove behind the callus. When the shell exfoliates, only a round umbilical plug is left. The spire is small and low, and the whorls are evenly rounded without a shoulder.

Holotype.-Herewith designated USNM 213951, plate 1 , figure 13.

Type locality._USGS $15310 \mathrm{~h}$. First large roadcut on west side of Scappoose-Vernonia Road, south of cutoff to Wilark, Columbia County, Oreg. Pittsburg Bluff Formation, middle Oligocene.

The body whorl of $C$. pittsburgensis is more inflated and is not so high as on Cryptonatica oregonensis (Conrad) (Moore, 1963, p. 27, pl. 2, figs. 2-4, 16, 17) from the Astoria Formation (Miocene), Oregon. The body whorl is less inflated than that of "Natica" weaveri Tegland (1933, p. 138-139) from the Gries Ranch (lower Oligocene) and Lincoln Creek (late Eocene to early Miocene) Formations in Washington.

Localities-USGS 2714, 5394, 15264, 15264a, 15264b, 15264e, 15310, 15310a-j, 15586, 15588, 18638, 21612, M3857, M3871, M3872, M3877, M3878. 


\section{Subfamily POLINICINAE}

Genus Polinices Montfort

Polinices Montfort, 1810, Conchyliologie systématique, v. 2, p. 223.

Type species.-By original designation, Polinices albus Montfort (=Natica mamillaria Lamarck = Natica brunnea Link). Holocene, West Indies.

Polinices washingtonensis (Weaver)

Plate 1, figures 14, 17, 20-22, 24

Natica washingtonensis Weaver, 1916a, Washington Univ. (Seattle) Pubs. Geology, v. 1, p. 44, pl. 5, figs. 73-76.

Polinices washingtonensis (Weaver). Clark and Anderson, 1938, Geol. Soc. American Bull., v. 49, p. 954, pl. 3 figs. 16, 17. Weaver, 1942, Washington Univ. (Seattle) Pubs. Geology, v. 5, p. 337, pl. 68, figs. 18, 23. Hickman, 1969, Oregon Univ. Mus. Nat. Hist. Bull. 16, p. 84-85, pl. 11, figs. 12-19.

Natica lincolnensis Weaver, 1916a, Washington Univ. (Seattle) Pubs. Geology, v. 1, p. 44-45, pl. 5, figs. 71, 72.

Polinices (Polinices) washingtonensis (Weaver) var. lincolnensis (Weaver). Weaver, 1942, Washington Univ. (Seattle) Pubs. Geology, v. 5, p. 337-338, pl. 68, fig. 22 , pl. 69 , figs. 4 , 7 .

Polinices washingtonensis is of moderate size with a fairly thick shell, moderate spire, evenly rounded body whorl, and spire without shoulders. The shell is smooth except for bunched radial lines that increase in prominence with erosion of the shell.

Holotype.-CAS 7516.

Type locality._Cut along Union Pacific Railway 1 mile north of Galvin Station, Lewis County, Wash. Lincoln Creek Formation, late Eocene to early Miocene.

Tegland (1933, p. 139), Clark and Anderson (1938, p. 954), and Hickman (1969, p. 85) thought that Polinices washingtonensis and Polinices lincolnensis were probably conspecific. Effinger (1938, p. 377) thought that the forms were probably distinct. Weaver (1942, p. 337-338) considered $P$. lincolnensis as a variety of $P$. washingtonensis; he believed that $P$. lincolnensis differed from $P$. washingtonensis by having the umbilicus wide open whereas the umbilicus of $P$. washingtonensis was covered by a heavy callus. He also believed that the two forms he described were of possible stratigraphic significance. On the basis of a comparison of type specimens of "Natica" washingtonensis Weaver (CAS 7516) and "Natica" lincolnensis Weaver (CAS 7515A) and other available material, it is my belief that they belong to one variable species. The specimens that were removed from the same piece of rock represent the two forms (pl. 1, figs. 17, 20). Therefore it is difficult to believe that they might be of stratigraphic significance. The degree of closure of the umbilicus is not related to the size of the specimen.

The type specimen of Polinices washingtonensis is smaller than that of Polinices washingtonensis lincolnensis. Because the inner edge of the callus lobe is broken on the type specimen of $P$. washingtonensis lincolnensis, an erroneous impression is given of the extent of coverage of the umbilicus; the umbilical area is larger than it is on $P$. washingtonensis. In the original description, the umbilical opening was said to be entirely absent on $P$. washingtonensis, but it is not entirely absent; the callus does not completely cover the umbilical area, there is a funnellike groove behind it. It is well known that the variability within species of the naticids can be great and that factors such as size, sex, and preservation increase this variability. With no evidence that the two forms $P$. washingtonensis and $P$. washingtonensis lincolnensis have different stratigraphic positions, it is illogical to separate them.

Localities.-USGS 2714, 5394, 15264, 15310, 15310a, c-e, g, h, 15588, M3871, M3878.

Occurrence elsewhere.-Gries Ranch Formation (early Oligocene), Quimper Sandstone of Durham (1942) (early and middle Oligocene), Lincoln Creek Formation (late Eocene to early Miocene), Blakeley Formation of Weaver (1912) (late Oligocene and early Miocene), Washington; Alsea Formation (early, middle and late Oligocene), Tunnel Point Sandstone (middle Oligocene), Eugene Formation (early and middle Oligocene), Oregon; Wheatland Formation of Clark and Anderson (1938) (late Eocene or early Oligocene), upper part of San Emigdio Formation (late Eocene to middle Oligocene), California.

\section{Genus Neverita Risso}

Neverita Risso, 1826, Histoire naturelle des principales production de l'Europe Méridionale, v. 4, p. 149.

Type species.-By monotypy, Neverita josephinia Risso. Holocene, Mediterranean Sea.

\section{Subgenus Glossaulax Pilsbry}

Glossaulax Pilsbry, 1929, Nautilus, v. 42, p. 113.

Type species.-Holotype by original designation, Neverita reclusiana (Deshayes). Holocene, southern California, and throughout Gulf of California to Tres Marias Islands, Mexico (Keen, 1971, p. 482).

\section{Neverita (Glossaulax) thomsonae Hickman Plate 2, figures 1-15}

Neverita (Glossaulax) thomsonae Hickman, 1969, Oregon Univ. Mus. Nat. Hist. Bull. 16, p. 84, pl. 11, figs. $20-23$.

Neverita thomsonae is moderate to large in size (largest specimen $47 \mathrm{~mm}$ wide and $39 \mathrm{~mm}$ high, incomplete); it has a thick shell, large globose body whorl, and a small, low spire. The suture is overlapping and no tabulation is present. The shell is usually smooth, but on some specimens (pl. 2, fig. 15) spiral lines can be seen near the base of the body whorl. The shape and size of the umbilical callus is variable, depending largely on the size of the entire shell. The largest shells have a very thick callus whereas the smallest shells have a callus of moderate thickness. The callus completely fills the umbilical area and is grooved. The posterior portion of the bifid callus is the largest and is rounded and pluglike; the anterior portion is small and triangular. 
The outer lip protrudes a few millimetres beyond the callus.

Holotype.-UO 27366. Paratypes: UO 27367-27372.

Type locality.-UO 2567. In well indurated brownish-gray tuffaceous sandstone and siltstone, east side of Oregon State Highway 47, 2 miles north of junction with Pittsburg-Scappoose Road. N1/2 sec. 23, T. 5 N., R. 4 W., Vernonia quadrangle. Type Pittsburg Bluff Formation (middle Oligocene), Oregon.

$N$. thomsonae is a much larger and heavier shelled form than any of the Eocene species of Neverita that I have examined. It is larger than Neverita jamesae Moore from the Astoria Formation (Miocene), Oregon (Moore, 1963, p. 28) and has a much larger and heavier umbilical callus.

Neverita lives intertidally on sandbars where it preys on clams (Keen, 1971, p. 482) and in lagoons and shallow bays (McLean, 1969, p. 37).

Localities. _USGS 2714, 5394, 15264, 15310, 15310a, $\mathrm{d}-\mathrm{g}, \mathrm{j}, 15311,15312,15588, \mathrm{M} 3857, \mathrm{M} 3858$, M3871, M3878.

Occurrence elsewhere.-Eugene Formation (early and middle Oligocene), Oregon; Wygal Sandstone Member of the Temblor Formation (late Oligocene), California.

\section{Subfamily SININAE \\ Genus Sinum Röding}

Sinum Röding, 1798, Museum boltenianum, pt. 2, p. 14.

Type species.-By subsequent designation (Dall, 1915, U.S. Natl. Mus. Bull. 90, p. 109), Helix haliotoidea Linné. Holocene, western Pacific Ocean(?). Subgeneric assignments are discussed by Addicott (1970c, p. 70).

\section{Sinum aff. S. obliquum (Gabb)}

Plate 1, figures 10,11

Two small specimens of Sinum (largest: $10 \mathrm{~mm}$ high, $9.3 \mathrm{~mm}$ wide) were collected from the Pittsburg Bluff Formation. Sinum aff. S. obliquum (Gabb) is thin shelled and has a small low spire and spiral cords of equal size with finer cords present in some but not all of the interspaces. The secondary cords are more numerous near the round shoulder. Of the described west American species, it resembles Sinum obliquum (Gabb) (1864, p. 109, 225, pl. 21, fig. 112) from the Eocene and Oligocene of the Pacific coast, but it seems to have a higher body whorl and a more ovate and perpendicular aperture. It is much smaller than Sinum scopulosum (Conrad) (1849, p. 727, pl. 19, figs. 6, 6a; Moore, 1963, p. 29, pl. 1, figs. 2, 3, pl. 2, figs. 20, 21) from the Miocene and Pliocene of the Pacific coast and seems to have a less inflated body whorl. It has not been possible to determine, on the basis of the two specimens available, if this is a new species.

Localities._USGS 15264, 15264e.

Occurrence elsewhere.-Of Sinum obliquum (Gabb):
Cowlitz (late Eocene) and Gries Ranch (early Oligocene) Formations, Washington; Keasey (late Eocene and early Oligocene) and Eugene (early and middle Oligocene) Formations, Oregon; Tejon Formation (early, middle and late Eocene), California.

\section{Family NEPTUNEIDAE \\ Genus Eosiphonalia Ruth}

Eosiphonalia Ruth, 1942, California Univ. Pubs., Dept. Geol. Sci. Bull., v. 26, no. 3, p. 288.

Type species.-By original designation, Strepsidura washingtonsis Weaver, Lincoln Creek Formation (late Eocene to early Miocene), Washington.

As noted by Ruth (1942, p. 288), Eosiphonalia is distinguished from Siphonalia by its lower spire, shorter and less recurved canal, biangulate body whorl that is more nodose, and lack of lirations on the inner lip. Eosiphonalia is an Oligocene genus endemic to California, Oregon, Washington, and Alaska.

\section{Eosiphonalia oregonensis (Dall) \\ Plate 4, figures 1-9}

Strepsidura oregonensis Dall, 1909, U.S. Geol. Survey Prof. Paper 59, p. 51, pl. 3, fig. 6 .

Siphonalia (Eosiphonalia) oregonensis Dall. Ruth, 1952, California Unit. Pubs., Dept. Geol. Sci. Bull., v. 26, p. 290, pl. 47, fig. 20.

Siphonalia oregonensis (Dall). Weaver, 1942, Washington Univ. (Seattle) Pubs. Geology, v. 5, p. 439, pl. 86, fig. 12.

Eosiphonalia oregonensis is of moderate size; the largest $\mathrm{s}$ specimen is $39.2 \mathrm{~mm}$ high and $27.5 \mathrm{~mm}$ wide (pl. 4, figs. 1, 3). The spire is low, making up a quarter of the total shell height, is tabulate, and has nodes on the shoulders. The body whorl is large, inflated, and sculptured usually by three or four, but sometimes five, prominent spirals that are separated by angulations. The spiral on the shoulder has nodes, and usually the next two anterior spirals are also noded. The entire shell is sculptured by fine spirals of approximately equal strength. The siphonal canal is deeply notched and slightly recurved. The area between the last strong spiral on the body whorl and the canal is moderately to deeply impressed.

Holotype.-USNM 107395, plate 4, figures 4, 6 .

Type locality._USGS 2714. In fine-grained brownish-gray sandstone in roadcut at Pittsburg Bluffs, Columbia County, Oregon. Pittsburg Bluff Formation, middle Oligocene.

Two described fossil species resemble $E$. oregonensis: E. washingtonensis (Weaver) (1916a, p. 48-49, pl. 5, figs. 81-83) from the Lincoln Creek Formation (late Eocene to early Miocene), Washington, and $E$. californica (Arnold) (1908, p. 370-371, pl. 33, fig. 12) from the San Lorenzo Formation (late Eocene to middle Oligocene), California. E. washingtonensis is a smaller form with a higher spire and stronger nodes, some of which are almost spinose. It has two or three raised 
spirals with nodes on the body whorl; the finer spirals are more prominent than on $E$. oregonensis. Weaver (1942, p. 439) said that $E$. washingtonensis has a nonornamented band just posterior to the siphonal fasciole at the end of the canal that distinguishes it from $E$. oregonensis; such an area is not discernible on the two specimens examined.

$E$. californica is a higher spired form, has stronger nodes than $E$. oregonensis, and has two angulations on the body whorl.

Localities.-USGS 15264, 15310, 15310a, d, 15532, 15537, 15588, M3857, M3871.

Occurrence elsewhere.-Poul Creek Formation (Oligocene and Miocene), Yakataga district, Gulf of Alaska.

\section{Genus Bruclarkia Trask}

Bruclarkia Trask in Stewart, 1926, Acad. Nat. Sci. Philadelphia Proc., v. 78, p. 397, 399.

Type species.-By original designation, Clavella gravida Gabb. Lower Miocene, Contra Costa County, Calif.

Bruclarkia is an endemic Pacific coast genus; it first appears in the early Oligocene and becomes extinct before the end of the Miocene. Its known geographic range is from California north to Alaska. Vokes (1939, p. 138) suggests that Bruclarkia may have developed from the Eocene genus Umpquaia (Turner, 1938, p. 79).

The degree of development of nodes and spines is not believed to be a specific character in Bruclarkia but rather to usually be an expression of variability within a species (Moore, 1963, p. 36). Exceptions may be found, of course, where there is a relation between degree of sculpture and stratigraphic occurrence. Characters that have been found to be valid in separating species of Bruclarkia are the configuration and extent of development of the shoulder on the body whorl, the number and spacing of the strong spiral cords on the body whorl, and the height of the spire in relation to the size of the body whorl.

Bruclarkia columbiana (Anderson and Martin)

Plate 3, figures 1-5, 21-23

Agasoma columbianum Anderson and Martin, 1914, California Acad Sci. Proc., ser. 4, v. 4, p. 73, pl. 5, figs. 6a, 6 b.

Bruclarkia columbiana (Andeeson and Martin). Weaver, 1942, Washington Univ. (Seattle) Pubs. Geology, v. 5, p. 443, pl. 87, figs. 7, 8. Durham, 1944, California Univ. Pubs., Dept. Geol. Sci. Bull., v. 27, p. 173. Hickman, 1969, Oregon Univ. Mus. Nat. Hist. Bull. 16, p. 94, pl. 13, figs. 12, 13.

Bruclarkia columbiana is the largest species in the genus; individuals grow to a height of $60 \mathrm{~mm}$ and a width of $48 \mathrm{~mm}$. The spire is low, about one-fourth the height of the body whorl, and the body whorl is greatly inflated. The species has three prominent spiral cords on the body whorl; the one on the shoulder and the one below it are nodose to slightly spinose; the third and most anterior spiral may be smooth or slightly noded. One noded prominent spiral may be present on the whorls of the spire at or just above the suture, which is strongly overlapping. On well-preserved specimens, a collar, sculptured by prominent spirals, is present at the suture (pl. 3, fig. 5), but this collar apparently exfoliates readily, as it is rarely preserved, even on specimens with the remainder of the shell intact. The entire surface of the shell is sculptured by subrounded spiral cords of varying strength that may be separated by finer secondary cords. The siphonal canal is long and recurved.

Holotype.-CAS 155. Paratype CAS 156.

Type locality. - At Pittsburg Bluffs, Columbia County, Oreg. Pittsburg Bluff Formation (middle Oligocene), Oregon.

The holotype of $B$. columbiana is $56 \mathrm{~mm}$ high and 40 $\mathrm{mm}$ wide, bears three nodose spirals on the body whorl, and has an overlapping, sinuous, swollen and collared suture. There are no nodes on the spire. The paratype of $B$. columbiana bears three spirals on the body whorl. These spirals are slightly spinose over two-thirds of the body whorl, but smooth on one-third of the body whorl near the aperture. The suture on the body whorl of the paratype is sinuous, overlaps the spire, and is strongly collared near the aperture. The whorls of the spire bear nodes on the spiral just above the suture on the paratype; they are smooth on the holotype.

Specimens of $B$. columbiana from USGS locality 15310 have much stronger nodes and are generally larger than specimens from other localities within the Pittsburg Bluff Formation.

$B$. columbiana is distinguished from other described species of Bruclarkia by the constant $40^{\circ}$ slope from the suture to the shoulder margin of the body whorl, the low spire, the strongly inflated body whorl, and the two prominent, noded spiral cords on the body whorl, one on the edge of the shoulder and the other below it.

Durham (1944, p. 173) reports $B$. columbiana from the Molopophorus gabbi, Turritella olympicensis, and $T$. porterensis Zones of northwestern Washington.

Localities.-USGS 2415, 2714, 2715, 2721, 5394, 15264, 15264a, 15310, 15310a-c, e, f, j, 15312, 15316, 15499 , 15532, 15586, 15588, 18638, M3858, M3871, M3872, M3877, M3878.

Occurrence elsewhere.-Quimper Sandstone of Durham (1942) (early and middle Oligocene), Marrowstone Shale (early Oligocene), and Lincoln Creek Formation (late Eocene to early Miocene), Washington; Alsea Formation (early to late Oligocene), upper part of the Eugene Formation (middle Oligocene), and Tunnel Point Sandstone (middle Oligocene), Oregon; Cymric Shale Member of the Temblor Formation (middle Oligocene), California. 


\section{Family BUCCINIDAE?}

Genus Molopophorus Gabb

Molopophorus Gabb, 1869, California Geol. Survey, Paleontology, v. 2, p. $156-157,219$, pl. 26, fig. 36 .

Type species.-By monotypy, Bullia (Molopophorus) striata Gabb. Tejon Formation, upper Eocene, California.

Molopophorus is an endemic Pacific coast genus appearing in the Eocene and becoming extinct by the end of the Miocene. It is found in Alaska, Washington, Oregon, and California, and is particularly common in the Pittsburg Bluff Formation.

\section{Molopophorus gabbi Dall \\ Plate 5, figures 1-22}

Molopophorus gabbi Dall, 1909, U.S. Geol. Survey Prof. Paper 59, p. 45, pl. 3, fig. 8. Anderson and Martin, 1914, California Acad. Sci. Proc., ser. 4, v. 4, p. 78, pl. 6, figs. 5a, 5b. Weaver, 1942, Washington Univ. (Seattle) Pubs. Geology, v. 5, p. 466-467, pl. 90, figs. 4, 6.

Molopophorus biplicatus quadranodosum Weaver, 1912, Washington Geol. Survey Bull. 15, p. 75-76, pl. 11, figs. 91-93; pl. 14, fig. 122.

Molopophorus gabbi is moderate in size (largest specimen $30 \mathrm{~mm}$ high and $20 \mathrm{~mm}$ wide); it has a rather thin shell, inflated body whorl, and short, deeply notched, siphonal canal. The most distinctive character of the species is its marked variation in body whorl sculpture. Usually the sculpture consists of four prominent spiral cords. Starting at the posterior end, the first three are equally spaced and the fourth has only half as much space separating it from the third spiral (pl. 5, figs. 10, 11, 16). On some specimens (pl. 5, figs. 8, 9 ), the four prominent spiral cords are equally spaced, and on the other specimens only three spiral cords are present (pl. 5, fig. 15). The spirals may be crossed by axial lines that form nodes (pl. 5, fig. 20) or spines (pl. 5, fig. 8) at the juncture or that may form axial ribs (pl. 5, fig. 12). The suture is sinuous and the collar overlaps the spire; more than one-third of the body whorl immediately below the suture is unsculptured. Immature forms lack the large unsculptured area on the body whorl and are usually more strongly sculptured over the rest of the shell.

Type.-USNM 107377 (pl. 5, figs. 19, 22) is herewith designated the lectotype. This is the specimen originally figured by Dall (1909, pl. 3, fig. 8) and represents the smooth form. A strongly sculptured specimen in Dall's type lot is assigned USNM 214016 (pl. 5, fig. 21). The remaining specimen in the type lot has been assigned USNM 214015.

Type locality._USGS 2714. Pittsburg, Columbia County, Oreg. Pittsburg Bluff Formation, middle Oligocene.

The lectotype (ANSP 4340) of Molopophorus biplicatus (Gabb) 1866, p. 9, pl. 2, fig. 14), from the San Ramon Sandstone (early Miocene?) in California, has a less inflated body whorl and a higher spire than $M$. gabbi. Its collar is not so strongly overlapping and prominent, nor does it have as large a concavity below the collar on the body whorl as $M$. gabbi. The three specimens in the type lot are not too well preserved, but they do show axial ribs on the body whorl that may become obsolete toward the aperture. Clark (1918, p. 174) considered $M$. gabbi and $M$. biplicatus to be so closely related that he considered $M$. gabbi to be a subspecies of $M$. biplicatus. The two specimens figured by Clark (1918, pl. 6, figs. 7a, 7b) were collected from the San Ramon Sandstone and compare well with $M$. biplicatus.

Weaver (1912, p. 75-76, pl. 11, figs. 91-93, pl. 14, fig. 122) described Molopophorus biplicatus quadranodosum from the middle Oligocene of Washington. Weaver (1942, p. 469) thought that the four prominently noded spiral ribs on the middle of the body whorl distinguished this subspecies. The large number of specimens of $M$. gabbi now available show that this ornamentation is common on $M$. gabbi. The holotype of $M$. biplicatus quadranodosum has been lost.

Molopophorus dalli Anderson and Martin (1914, p. 78, pl. 6, figs. 7a, 7b) lacks the strong sculpture of $M$. gabbi and never has nodes or spines, although it may be cancellate or beaded (Hickman, 1969, p. 91, pl. 13, fig. 1). $M$. dalli was originally collected near Clatskanie, Oreg., in rocks that are now assigned to the Gries Ranch Formation (early Oligocene) (Warren and others, 1945). Durham (1944, p. 170) reports $M$. dalli from his Molopophorus gabbi Zone, specifically from a locality in the Quimper Sandstone of Durham (1942) (middle and late Oligocene), Washington. Hickman (1969, p. 91) reports the rare occurrence of $M$. dalli in the lower and middle Eugene Formation, which she assigns to the early Oligocene. She also collected some specimens of $M$. dalli from the Salem area, in beds questionably referred to the upper (middle Oligocene) part of the Eugene Formation. $M$. dalli has not been found in any of the collections from the Pittsburg Bluff Formation at hand, and it seems probable that $M$. dalli may be restricted to the early Oligocene.

Molopophorus lincolnensis Weaver (1916a, p. 50, pl. 4, figs. 60,61 ), a common species in the Lincoln Formation (late Eocene to early Miocene) in Washington, is distinguished from $M$. gabbi by its smaller size and lack of spiral sculpture. The sculpture consists only of axial ribs.

Localities._USGS 2415, 2714, 5394, 15264, 15264a, e, d, 15278, 15310, 15310a-j, 15311, 15312, 15532, 15544, 15586, 15588, 18638, 18779, M3858, M3860, M3871, M3877, M3878.

Occurrence elsewhere.-Quimper Sandstone of Durham (1942) (early and middle Oligocene), reported by Weaver (1916d, p. 39) from the Lincoln Creek 
Formation (late Eocene to early Miocene), Washington; Gries Ranch Formation (early Oligocene), USGS 5210, Tunnel Point Sandstone (middle Oligocene), Oregon; San Lorenzo Formation (late Eocene to middle Oligocene), California (Clark, 1915, p. 18).

\section{Family FUSINIDAE \\ Genus Priscofusus Conrad}

Priscofusus Conrad, 1865, Am. Jour. Conchology, v. 1, p. 150.

Type species.-By subsequent designation (Cossman, 1901, Essais de paleoconchologie comparée, p. 8), Fusus geniculus Conrad. Astoria Formation, Miocene, Oregon.

Priscofusus is an endemic Pacific coast genus appearing in the Paleocene and becoming extinct in the Pliocene. Its geographic range is Alaska to California.

\section{Priscofusus stewarti (Tegland)}

Plate 3, figures 17-19

Fusinus (Priscofusus) stewarti Tegland, 1933, California Univ. Pubs., Dept. Geol. Sci. Bull., v. 23, p. 129-30, pl. 12, figs. 4-8. Weaver, 1942, Washington Univ. (Seattle) Pubs. Geology, v. 5, p. 486-487, pl. 93, figs. 3, 4, 10, 14 .

Two small specimens of Priscofusus stewarti are in the collections; one is almost complete; the other has only the spire preserved. $P$. stewarti is slender in outline with small somewhat elongate nodes one-third the whorl height above the suture. The surface is sculptured with closely spaced subrounded spiral ribs of slightly different widths; between the ribs there may be a spiral thread.

\section{Holotype.-UCMP 32238.}

Type locality.-Restoration Point, opposite Seattle, Wash. Blakeley Formation of Weaver (1912) (late Oligocene and early Miocene).

Priscofusus chehalisensis (Weaver) (1912, p. 78-79, pl. 6, figs. 65, 66) is larger and has a much higher and slimmer spire than $P$. stewarti.

Localities._USGS 15264, 15588, M3871.

Occurrence elsewhere.-Poul Creek Formation (middle Oligocene to early Miocene), Yakataga district, Gulf of Alaska; Blakeley Formation (late Oligocene and early Miocene), Washington; Alsea Formation [early to late Oligocene].

\section{Family FASCIOLARIIDAE}

Genus Perse Clark

Perse Clark, 1918, California Univ. Dept. Geology Bull., v. 11, p. 179.

Type.-By original designation, Perse corrugatum Clark. San Ramon Sandstone (early Miocene?), California.

Perse is an endemic west coast genus found in Eocene to Miocene rocks in California, Oregon, and Washington. It first appears in the late Eocene and becomes extinct at the end of the early Miocene, or the end of the Oligocene, depending upon the age assignment given to the Blakeley and San Ramon
Formations of Washington and California, respectively.

Stewart (1926, p. 401-402) proposed a new genus, Whitneyella and designated Hemifusus washingtoniana Weaver (1912, p. 46-47, pl. 2, fig. 11, not fig. 12) as the type species. Stewart considered the type specimen of Perse corrugatum to be generically distinct from the group represented by Hemifusus washingtoniana, although Clark had placed $H$. washingtoniana in his genus Perse. In 1938, Clark (p. 718-719) placed Whitneyella in synonymy with Perse, saying that the anterior end of the canal of the poorly preserved type specimen of $P$. corrugatum was broken off and that the original illustration was therefore misleading. Examination of the type specimen of $P$. corrugatum shows it to be congeneric with Hemifusus washingtoniana, and this group is therefore assigned the older name Perse.

Perse is usually of small to moderate size, it has a thin shell that has a long, slightly recurved canal. The anterior end of the canal is very narrow, and specimens are rarely collected with the canal intact. On broken specimens, the narrowness of the canal may lead one to suppose erroneously that it would have been about half of its actual length. Slightly rounded to flat-topped spiral cords form the predominant sculpture. These cords may have weak nodes or axial swellings. The suture is collared and overlaps the spire; the collar varies in strength and may be smooth or sculptured by spiral cords. The spire is usually low and less sculptured than the body whorl. A pronounced concavity occurs between the suture and the maximum inflation of the whorls; this concavity is particularly well developed on the body whorl.

\section{Perse pittsburgensis Durham}

Plate 6, figures 1, 4, 6, 7, 9, 12-14, 18-20

Perse pittsburgensis Durham, 1944, California Univ. Pubs., Dept. Geol. Sci. Bull., v. 27, p. 175, pl. 16, figs. 2, 4.

Perse pittsburgensis is a small- to moderate-sized species (largest specimen: $27 \mathrm{~mm}$ high, $15 \mathrm{~mm}$ wide) with a thin shell. The suture is collared and overlaps the spire; the collar usually bears two closely spaced, flat spirals. The spire and body whorl are sculptured by slightly rounded, straplike spiral cords that are generally smooth but may be slightly noded. The spirals are most strongly developed on the maximum swelling of the whorls, and all are separated by interspaces that may be equal to one and one-half times the width of the spirals. The wider interspaces may bear a secondary spiral thread. A concavity is present on the body whorl between the suture and the first strong spiral just above the maximum point of inflation; it generally bears spirals of somewhat smaller size than on the rest of the body whorl. The whorls of the spire are roundly tabulate. The siphonal canal is long, very narrow, and slightly recurved (pl. 6, figs. 1,4 ). 
Holotype.-UCMP 35409.

Type locality. - In bluffs along road along the east side of the highway along the Nehalem River, about 21 miles south of Mist and 0.2 mile north of junction with road to St. Helens, and 0.25 mile north of bridge. Pittsburg Bluff Formation (middle Oligocene), Oregon.

$P$. pittsburgensis varies considerably in degree of sculpture, but it always bears straplike spiral cords and has a characteristic outline with a low spire and an inflated body whorl bearing a deep but relatively short sinus. $P$. pittsburgensis vernoniensis has a longer concavity between the suture and the periphery, and bears, if any, only one strong straplike spiral on this concavity. The sculpture usually consists of fine spiral threads. The entire shell is slimmer and the spire is higher than that of $P$. pittsburgensis.

Perse olympicensis Durham (1944, p. 174-175, pl. 16, fig. 1), from the early Oligocene Molopophorus stephensoni Zone, does not bear the straplike spirals of $P$. pittsburgensis. $P$. olympicensis quimpersensis Durham (1944, p. 175, pl. 16, figs. 5, 6), from the middle Oligocene Molopophorus gabbi Zone, is distinguished by having longitudinal ribs.

Localities._USGS 2714, 2722, 5394, 15264, $15264 \mathrm{~b}, \mathrm{c}, \mathrm{e}, 15278,15310,15310 \mathrm{~b}, \mathrm{c}, \mathrm{e}-\mathrm{j}, 15311,15312$, $15519,15537,15545,15586,15588,18638,18779$, M3856, M3857, M3858, M3866, M3868, M3871, cf. M3872, M3877, M3878.

Occurrence elsewhere.-Alsea Formation (early, middle, and late Oligocene), Oregon.

\section{Perse pittsburgensis vernoniensis, $n$. subsp. \\ Plate 6, figures 2, 3, 5, 8, 10, 11, 15-17}

Perse pittsburgensis vernoniensis is fusiform in outline, is of moderate size (largest specimen: $29 \mathrm{~mm}$ high, $16 \mathrm{~mm}$ wide), and has a higher spire than is usual for Perse. It is sculptured with rounded spiral cords which may be noded with axial swellings (pl. 6, figs. 10, 17), noded without axial swellings (pl. 6, fig. 16), or fairly smooth (pl. 6, figs. 2, 3). Secondary cords of about half the width of the primaries may be present in the interspaces, but their occurrence and distribution is random. The interspace may be two to three times as wide as the spiral cord. Fine spiral threads are present on the sinus of the body whorl and on the sinus of the spire whorls, if such a sinus is present. The canal is very long, slender, and slightly recurved; the entire canal is not preserved on any specimen. The inner lip is lirate; the suture is overlapping and collared and the collar bears one or two spiral cords. Below the collar is a sinus; it is strongly developed on the body whorl, occasionally shows on the two preceding whorls, but is never present on the first three whorls. The sinus is always sculptured by fine spiral threads and may also bear one strong spiral cord.
Holotype.-USNM 214017 is herewith designated the holotype (pl. 6, figs. 5, 8).

Type locality.-USGS 15588. Cut in logging road along the headwaters on the second main tributary entering Coal Creek from the northeast of its junction with Pebble Creek, 3,900 feet west of grid 820 and 5,200 feet south of grid 2,650, Vernonia quadrangle. Pittsburg Bluff Formation (middle Oligocene), Oregon.

The shape and sculpture distinguish P. pittsburgensis vernoniensis, although, as can be seen on plate 6 , the sculpture is variable. The spire is higher, the sinus is less sculptured and more pronounced, and the spiral cords are finer and farther apart than on Perse pittsburgensis; $P$. pittsburgensis vernoniensis, has a longer concavity between the suture and the maximum swelling of the body whorl, and bears, if any, only one strong straplike spiral on this concavity. The sculpture consists usually of fine spiral threads. The entire shell is slimmer than that of $P$. pittsburgensis.

Perse lincolnensis (Van Winkle) (1918, p. 89-90, pl. 7, fig. 10) is higher spired than $P$. pittsburgensis vernoniensis with finer spiral sculpture that bears nodes or spines.

Perse olympicensis Durham (1944, p. 174-175, pl. 16, fig. 1) does not bear straplike spirals like $P$. pittsburgensis vernoniensis does, and $P$. olympicensis quimpersensis Durham (1944, p. 175, pl. 16, figs. 5, 6) is distinguished by longitudinal ribs.

$P$. pittsburgensis vernoniensis occurs at only eight localities in the Pittsburg Bluff Formation but is very abundant at these localities and occurs with $P$. pittsburgensis at many of them.

Localities._USGS 2714, 15264, 15536, 15588, 18779, 21612, M3871, M3872, M3878.

\section{Family TURRIDAE \\ Subfamily TURRICULINAE \\ Genus Aforia Dall}

Aforia Dall, 1889, Mus. Comp. Zool. Bull. 18, p. 99.

Type species. - By original designation, Pleurotoma circinata Dall. Holocene, North Pacific.

The known fossil occurrences of Aforia are in the Pliocene of Japan, the Oligocene to Pliocene of Washington, the Oligocene and Miocene of Oregon, and the Oligocene or Miocene of California (Powell, 1966, p. 44; Javidpour, 1973, p. 197).

\section{Aforia campbelli Durham Plate 7, figure 22}

Aforia campbelli Durham, 1944, California Univ. Pubs., Dept. Geol. Sci. Bull., v. 27, p. 183-184, pl. 14, fig. 4. Javidpour, 1973, Veliger, v. 15, p. 199-200, figs. $1,6,10$.

Aforia clallamensis (Weaver) subsp. wardi (Tegland). Weaver, 1942, Washington Univ. (Seattle) Pubs. Geology, v. 5, p. 516-517, in part, pl. 97, fig. 10, not pl. 96, fig. 6 .

Six whorls of the spire of one specimen are preserved as an external cast of Aforia campbelli. A rubber im- 
pression that was made from it is illustrated in plate 7, figure 22. Aforia campbelli is a large species, pagodiform in outline; it has a sharp carina just above the suture. The whorl is concave above the carina and deeply concave below it. The sinus is deep and broadly U-shaped and is located in the middle of the shoulder above the carina. The shell seems to have been spirally sculptured below the carinae.

Holotype.-UCMP 14961.

Type locality.-A1636. Type "Porter" Bluffs along northeast side of highway beginning at a point 270 yards southeast of first exposure southeast of Porter Station and extending 180 yards. Grays Harbor County, Wash. Middle Oligocene, Lincoln Creek Formation.

$A$. campbelli has a slimmer spire and higher shoulder above the angulation than $A$. wardi (Tegland, 1933, p. 124, pl. 10, figs. 5-8), and the angulation is closer to the suture than on A. wardi. A. addicotti Javidpour (1973, p. 201 , figs. 8,12 ) has the angulation closer to the middle of the whorl and does not have as deep a concavity below the angulation as $A$. campbelli. A. clallamensis (Weaver, 1916a, p. 52, pl. 4, fig. 59) has the angulation near the middle of the whorl; the shoulder above the angulation is not so high nor so concave as on $A$. campbelli and the spire is slimmer. A. clallamensis does not have a deep concavity beneath the angulation.

Javidpour (1973, p. 196-199) has discussed the phylogenetics of the six species of Aforia reported from the west coast of North America. To her record should be added the occurrence of $A$. campbelli in the Pittsburg Bluff middle Oligocene of northwestern Oregon and of A. clallamensis (Weaver) in the Astoria Formation, Miocene, of the Newport area, Oregon (Moore, 1963, p. 47 , pl. 10 , figs. 16,18 ).

Locality._USGS 15519.

Occurrence elsewhere.-Lincoln Formation (late Eocene to early Miocene), Washington.

\section{Subfamily TURRINAE? \\ Genus Taranis Jeffreys}

Taranis Jeffreys, 1870, Ann. Mag. Nat. Hist., ser. 4 (5), p. 447.

Type species.-By monotypy, Trophon morchi Malm. Holocene, North Atlantic.

Taranis has a very small, ovate-biconic, predominantly medially angulate and spirally keeled shell. The protoconch is paucispiral, of barely two whorls, papillate to slightly globose, superficially smooth, but it has a microscopic sculpture of closely spaced stippled spiral lirae. The sinus is shallow; its apex is at the peripheral angle or major keel; and its angles of approach are unequal-steep and straight above, protractively arcuate below. The pillar is abruptly twisted at the beginning of a short shallowly notched anterior canal. The subfamily position of Taranis is problematic, but based on the type of sinus, the apex of which is peripheral, the genus is provisionally placed in the Turrinae (Powell, 1966, p. 55).

The known fossil occurrences of Taranis are in the Pleistocene of England, Sicily, California, and New Zealand; the Pliocene of Italy; the Oligocene and Miocene of Oregon; and the Miocene of California.

Taranis columbiana (Anderson and Martin)

Plate 7, figures 2, 3, 5-8, 16, 37

Drillia columbiana Anderson and Martin, 1914, California Acad. Sci. Proc., ser. 4, v. 4, p. 94, pl. 7, figs. 4a, 4b. Not Drillia columbiana Anderson and Martin of Adegoke, 1969, California Univ. Pubs. Geol. Sci., v. 80, p. 192, pl. 13, fig. 10.

Thesbia columbiana (Anderson and Martin). Weaver, 1942, Washington Univ. (Seattle) Pubs. Geology, v. 5, p. 537, pl. 99, fig. 13.

Taranis columbiana has a rather thick shell and a moderately high spire. The sinus is shallow, U-shaped, and confined to the keel with almost equal angles of approach. The angles are perhaps a bit steeper above than below the sinus. The protoconch consists of a little more than one and one-half rounded, smooth whorls (pl. 7, fig. 8). At the apex is a twisted, recurved, hooklike process that is centrally located. This process forms a spur off the protoconch, rather than from the tip of the last whorl, and looks as if it were the columella protruded from the center. The body whorl is small and canal is short, recurved, and slightly notched.

Holotype.-CAS 231; paratype CAS 232.

Type locality. - Northwest Oregon. This is the locality cited by Anderson and Martin (1914, p. 94) and agrees with the label on the type specimens. The locality cited by Weaver (1942, p. 537), "(CAS 65) West bank of small canyon one and one-fourth miles northeast of Barker's Ranch house in Kern County, California" is in error. In addition to checking the label with the holotype of "Drillia" columbiana, the late Leo G. Hertlein, California Academy of Sciences, kindly checked the collection from locality CAS 65 and found no specimen labelled " $D$ " columbiana. Presumably the type specimens of "Drillia" columbiana were collected from the Pittsburg Bluff Formation near Vernonia, Oreg.

Twenty specimens that are well enough preserved to show shell sculpture are in the collections. These specimens show three different forms of sculpture, and specimens of each type are present at a single locality (M3871). On the smooth-keeled form (pl. 7, figs. 6, 16) the keel is smooth, straplike, slightly rounded, and not sculptured. There are no spirals above or below the keel on the spire. There is no spiral sculpture above the keel on the body whorl. Below the keel a strong spiral forms an angulation on the body whorl and above the angulation are one or two fine spirals. Below the second strong spiral is a weaker but still strong spiral and beneath this weaker one are eight fine spirals of equal strength. On the intermediate form (pl. 7, fig. 37) the keel on the early whorls is thin and smooth; the keel on 
the later whorls is again straplike but bears three to four spiral cords. The whorls have a ridgelike collar bearing one or two spiral threads. Between the collar and the keel may be an additional spiral thread. Below the keel on the whorls of the spire is a fairly prominent spiral cord. Below the keel on the body whorl are three equally spaced smooth spiral cords followed by about seven or eight finer, equally spaced spirals. On the sculptured-keeled form (pl. 7, fig. 5), the keel spiral is thin and rather pointed; above the keel are three fine spirals and on the collar one stronger spiral and one fine spiral. Above the keel, half way between the keel and the suture, is a strong, sharply pointed spiral and below it, right at the suture, is a smaller, more rounded spiral. The keel of the body whorl is formed by one sharply pointed spiral above which are three closely spaced finer spirals and one spiral on the collar. Below the keel are three strong equally spaced spirals followed by eight closely spaced finer spirals. Given only the smoothkeeled and sculptured-keeled forms, it would probably seem as if two species were present, but the intermediate form points to the fact that $T$. columbiana varies markedly in its spiral sculpture.

Hickman (written commun., 1975) assigns Taranis columbiana to Ptychosyrinx.

The specimen figured by Adegoke (1969, pl. 13, fig. 10) as Drillia columbiana Anderson and Martin, from the Temblor Formation (Oligocene and Miocene), Coalinga region, California, is much larger and different in outline than Taranis columbiana. It lacks the deep concavity below the whorl sutures of $T$. columbiana.

Localities.-USGS 15264, 15264a, b, 15310, 15310d, M3871, M3872, cf. 15278.

\section{Subfamily CLAVINAE Genus Spirotropis Sars}

Spirotropis Sars, 1878, Mollusca regionis Arcticae Norvegicae, p. 242, pl. 17 , figs. 5a, 5 b.

Type species.-By monotypy, Spirotropis carinata Philippi. Holocene, Norway to Azores.

Spirotropis is thin shelled and has a moderately high spire and has roundly keeled whorls. The sinus, which is rather deep and U-shaped, is confined to the shoulder above the keel. Powell (1966, p. 74) says that the typical adult has medially carinate whorls but is otherwise smooth except for some weak, oblique, peripheral nodes on the early postnuclear whorls.

The known fossil occurrences of Spirotropis are in the Miocene to Pleistocene of Europe and the Oligocene to Pleistocene of northwestern America (Powell, 1966, p. 75).

\section{Spirotropis kincaidi (Weaver)}

Plate 7 , figures $1,9,10,13$

Turris kincaidi Weaver, 1916a, Washington Univ. (Seattle) Pubs. Geology, v. 1, p. 53, pl. 5, fig. 67.
Turricula kincaidi (Weaver). Tegland, 1933, California Univ. Pubs. Dept. Geology, v. 23, p. 126-127, pl. 10, figs. 12, 13.

Spirotropis kincaidi (Weaver). Grant and Gale, 1931, San Diego Soc. Nat. Hist. Mem., v. 1, p. 548. Weaver, 1942, Washington Univ. (Seattle) Pubs. Geology, v. 5, p. 522, pl. 97, figs. 18, 19, 25.

Spirotropis kincaidi is small to moderate in size and bears a sharply rounded keel or shoulder just above the suture. The whorls of the spire are smooth above the keel except for the U-shaped sinus and three flat-topped spiral cords below the keel. The body whorl is sculptured with similar flat spiral cords below the keel which are closely spaced. No nodes are discernible on any of the specimens examined, nor are they present on the holotype. The protoconch consists of two smooth whorls with the apex slightly arcuate and recurved.

\section{Holotype.-CAS 470.}

Type locality._UW 256. In Union Pacific Railway cut 1 mile north of Galvin Station, Lewis County, Wash. Lincoln Creek Formation (late Eocene to early Miocene).

Hickman (written commun., 1975) assigns Spirotropis kincaidi to the genus Parasyrinx.

Spirotropis kincaidi has a shorter, wider spire and a more sharply rounded keel than $S$. washingtonensis Etherington (1931, p. 113, pl. 14, figs. 8, 22, 34).

Localities.-USGS 15264, 15310, 15310d, 15588, M3856, M3857, M3871, M3872, M3878.

Occurrence elsewhere.-Lincoln Creek Formation (late Eocene to early Miocene) and Blakeley(?) Formation (late Oligocene and early Miocene), Washington; Tunnel Point Sandstone (middle Oligocene), Oregon.

\section{Genus Suavodrillia Dall}

Suavodrillia Dall, 1918, U.S. Natl. Mus. Proc., v. 54, no. 2238, p. 331.

Type species.-By original designation, Drillia kennicotti Dall, Holocene, Alaska. Bering Strait south to the Aleutian Islands.

The known fossil occurrences of Suavodrillia are in the Miocene and Pliocene of Japan and the Oligocene of Washington and Oregon.

Some of the diagnostic features of Suavodrillia, as given by Powell (1966, p. 82), are

Shell moderately large, up to $37 \mathrm{~mm}$, rather thin, claviform, with a tall pagodiform spire and a narrow body-whorl, quickly contracted to a moderately long, decidedly twisted, and rather deeply notched anterior canal. Protoconch small, turbinate of $2^{1 / 2}$ smooth whorls, the tip almost central and slightly inrolled. Spire-whorls dominated by a strong but narrowly rounded keel, which is situated at about a third whorl height. Body-whorl and a second keel, emergent at the lower suture, and seven more below to the anterior end, but becoming progressively weaker. There is also a broad but weak subsutural fold which bears two closely spaced fine threads at its lower margin. The shoulder slope is wide, flat and steep, which with the carina, impart the pagodalike profile to the spire. Aperture ovate-pyriform. Outer lip thin edged, with a moderately deep U-shaped sinus, at the apex of a wide, chevron-shaped entrance; the apex is on the lower part of the shoulder slope, immediately above the carina. The inner lip is a slightly excavated smooth callus with processes. 
Power cites Suavodrillia hertleini Durham (1944, p. 182-183, pl. 14, fig. 1) from the Oligocene of Washington as a characteristic species.

\section{Suavodrillia winlockensis (Effinger)}

Plate 7, figures $4,11,12,15,33-36,38$

Surcula dickersoni (Weaver). Dickerson, 1917, California Acad. Sci. Proc., ser. 4, v. 7, p. 161, pl. 31, figs. 3a, 3b.

Spirotropis (Spirotropis) winlockensis Effinger, 1938, Jour. Paleontology, v. 12, p. 386, pl. 46, figs. 12 , 16. Weaver, 1942, Washington Univ. (Seattle) Pubs. Geology, v. 5, p. 520-521, pl. 97, figs. 5, 8, 9.

Suavodrillia winlockensis is a small thin-shelled species with a high, slim, turreted spire. The aperture is ovate, and the siphonal canal is moderately long, recurved, and notched. The primary sculpture consists of one strong narrow keel at the shoulder, a strong concavity just below the shoulder, and two strong rounded spirals on this concavity. The posterior spiral is one half as wide as the anterior one. The surface above the shoulder has fine slightly rounded spirals of unequal width that are closely spaced. Below the shoulder on the body whorl are three slightly rounded strong spirals alternating with weaker spirals of half the width. The remainder of the shell to the tip of the canal bears flat-topped spiral cords of lesser strength; these cords alternate with incised lines. The sinus occupies most of the shoulder and is shaped like a rounded, very open $\mathrm{V}$. The early whorls of some immature shells show a second strong spiral just above the suture, and instead of being concave are straight sided. Well-preserved juvenile specimens may bear a fine reticulate sculpture on the shoulder; the sculpture is formed by fine spiral threads crossing the lines of the suture. The size and arrangement of secondary spiral cords varies considerably on different specimens. On a few specimens the keel is grooved. The protoconch is small and smooth with the tip almost central.

Holotype.-UCMP 33607.

Type locality.-UW 239. South bank of the Cowlitz River at old Gries Ranch, Lower Cowlitz Valley, Wash. Gries Ranch Formation (early Oligocene).

Suavodrillia dickersoni (Weaver) (1916a, p. 54, pl. 5, fig. 66), from the Lincoln Creek Formation (late Eocene to early Miocene), Washington, is not so strongly keeled and seems to have a much shorter siphonal canal.

Localities._USGS 15264, 15264b, e, 15310, 15310a, c, e, f, h, j, 15499, 15530, 18638, 21612, M3871, M3878.

Occurrence elsewhere.-Gries Ranch Formation (early Oligocene), Washington.

\section{Family PYRAMIDELLIDAE \\ Genus Odostomia Fleming}

Odostomia Fleming, 1813, Brewster's Edinburgh Encyclopedia, v. 7, pt. 1, p. 76.

Type species.-By subsequent designation (Gray, 1847, Zool. Soc. London Proc., pt. 15, p. 159), Turbo plicatus Montagu. Holocene, Europe.

\section{Odostomia winlockiana Effinger}

Plate 3, figures 7, 9, 10

Odostomia (Odostomia) winlockiana Effinger, 1938, Jour. Paleontology, v. 12 , p. 375 , pl. 46 , figs. $13,17,20$. Weaver, 1942 , Washington Univ. (Seattle) Pubs. Geology, v. 5, p. 306-307, pl. 64, figs. $23,24,30$.

Shell very small (2.5-4.5 mm high and 1.0-2.2 mm wide), adult specimens probably have five whorls. The surface is white and polished, and the protoconch heterostrophic. A single fold can be seen on the columella. The sutures are linear and impressed. The body whorl is moderately large, and the aperture probably subovate.

Holotype.-UCMP 33564.

Type locality. - In south bank of Cowlitz River at old Gries Ranch, N1/4 sec. 25, T. 11 N., R. 2 W., Cowlitz County, Wash. Gries Ranch Formation, early Oligocene.

The species is distinguished by the moderately rounded whorls and impressed sutures. Odostomia may be parasitic upon the mollusks $O$ strea, Pecten, and Crepidula and on polychaete worms (Keen, 1971, p. 770).

Localities._USGS 5329, 15310.

Occurrence elsewhere.-Gries Ranch Formation (early Oligocene), Washington.

\section{Family ACTEONIDAE \\ Genus Acteon Montfort}

Acteon Montfort, 1810, Conchyliologie systématique, v. 2, p. 315.

Type species.-By original designation, Voluta tornatilis Gmelin = Voluta tornatilis Linné. Holocene seas of Europe.

Acteon chehalisensis (Weaver)

Plate 7, figures 20, 21

Acteocina chehalisensis Weaver, 1916a, Washington Univ. (Seattle) Pubs. Geology, v. 1, p. 55, pl. 4, figs. 55, 56.

Acteon chehalisensis (Weaver). Weaver, 1942, Washington Univ. (Seattle) Pubs. Geology, v. 5, p. 543, pl. 99, figs. 38-40.

Three incomplete specimens are in the collections examined. The body whorl is large and somewhat elongate, and the spire is moderately high and consists of four whorls. The body whorl of the middle-sized specimen bears about 30 spiral ribs. The body whorl of the largest specimen has twice as many ribs; they each seem to have split in two. The smallest specimen does not have the outer shell layer preserved. Fine axial threads occur in the spaces between spiral ribs. The spirals are offset at irregular intervals on the largest specimen.

Holotype.-CAS 474.

Type locality.-UW 352. In Union Pacific Railway cut 1 mile north of Galvin Station, Lewis County, Wash. Lincoln Creek Formation (late Eocene to early Miocene).

Acteon parvuum Dickerson (1917, p. 172, pl. 29, figs. $12 \mathrm{a}, 12 \mathrm{~b}$ ) from the Gries Ranch Formation (early 
Oligocene), Washington, has a more inflated body whorl, lower spire, and only about 20 spiral ribs. Although $A$. parvuum has been recorded from the Pittsburg Bluff Formation (Warren and others, 1945), it is not present in the collections studied.

Localities.-USGS 15264, 15537, 15588, M3871.

Occurrence elsewhere.-Lincoln Creek Formation (late Eocene to early Miocene), Washington.

\section{Acteon? n. sp.? \\ Plate 7, figure 19}

A small (4 mm high, incomplete; $2.7 \mathrm{~mm}$ wide) incomplete, poorly preserved specimen of Acteon? is in the collections. It is unique in that the shell is not completely sculptured by spiral ribs or incised lines. The smallest whorl on the shell has widely spaced spiral lines. The next largest whorl is smooth except for one incised line seen where the next whorl has broken away at the suture. The upper third of the body whorl is smooth; the lower two-thirds is sculptured with incised lines except at the base where the sculpture is of flattopped spiral ribs. The aperture is almost completely missing, but the inner lip seems to be thickened, and the general outline of the aperture is similar to that of Acteon. As all the fossil species of Acteon seen have had all the whorls spirally sculptured, it seems improbable that this specimen is simply an immature form of Acteon chehalisensis (Weaver) or of some other described fossil species.

Locality._USGS 15588.

Family SCAPHANDRDAE

Genus Scaphander Montfort

Scaphander Montfort, 1810, Conchyliologie systématique, v. 2, p. 335.

Type species.-By original designation, Bulla lignaria Linné. Holocene, eastern North Atlantic to Mediterranean Sea.

\section{Scaphander stewarti Durham}

Plate 7, figures 18, 23-32

Scaphander stewarti Durham, 1944, California Univ. Pubs., Dept. Geol. Sci. Bull., v. 27, p. 189, pl. 14, fig. 15. Hickman, 1969, Oregon Univ. Mus. Nat. Hist. Bull. 16, p. 100-101, pl. 14, figs. 1-3.

Scaphander stewarti is of moderate size, thin shelled, and subovate in outline. The spire is sunken and covered with callus that continues as a ridge on the posterior edge of the aperture to the outer lip edge. The outer lip leaves the spire at an angle and flares out beyond the body whorl. The shell is so thin that the outer lip is usually broken off; it is not completely preserved on any of the specimens in the collections examined. The shell is sculptured with flat spiral ribs that are grooved medially on the posterior portion of the shell and are split into two ribs on the anterior portion. The ribs are of unequal width and are serrated along the edges.

Holotype.-UCMP 35483.
Type locality.-In seacliff SW1/4 NE $1 / 4$ sec. 19, T. 29 N., R. 1 E., Nordland quadrangle, Jefferson County, Wash.Quimper Sandstone of Durham (1942) (early and middle Oligocene).

Scaphander stewarti differs from Scaphander washingtonensis Weaver (1916a, p. 56, pl. 5, fig. 68) by having the lip more roundly truncated at the anterior end. The aperture is more inflated anteriorly, and the outer lip leaves the spire at an upward angle.

Localities._USGS 2714, 5407, 15264, 15264b, e, $15310,15310 \mathrm{a}, \mathrm{b}, \mathrm{d}, \mathrm{j}, 15312,15537,15545,15583$, 15586, 15588, 18638, 21612, M3858, M3868, M3871, M3872, M3878.

Occurrence elsewhere.-Quimper Sandstone of Durham (1942) (early and middle Oligocene), Washington; Gries Ranch Formation (early Oligocene), Keasey Formation (late Eocene and early Oligocene), and Eugene Formation (early and middle Oligocene), Oregon.

\section{Class SCAPHOPODA \\ Family DENTALIIDAE \\ Genus Dentalium Linné}

Dentalium Linné, 1758, Systema naturae, ed. 10, p. 785 .

Type species.-By subsequent designation (Montfort, 1810), Dentalium elephantinum Linné. Holocene, Amboynaland, Philippine Islands.

\section{Subgenus Fissidentalium Fischer}

Type species.-By monotypy (Fischer, 1885, Manuel de Conchyliologie, p. 894), Dentalium ergasticum Fischer. Living in Gulf of Gascony and the Atlantic Ocean ranging in water depth from 400 to $1,900 \mathrm{~m}$.

Dentalium (Fissidentalium?) laneensis Hickman Plate 7, figures 14, 17

Dentalium (Fissidentalium?) laneensis Hickman, 1969, Oregon Univ. Mus. Nat. Hist. Bull. 16, p. 74, pl. 9, figs. 1-6.

About 30 specimens of Dentalium are in the Pittsburg Bluff collections; of these about 10 have some of the original shell preserved, although none of them are complete specimens. The longitudinal ribs are narrow, strong, and rounded near the apex. Secondary ribs may appear between 8 and $10 \mathrm{~mm}$ from the apex where the primary ribs become less pronounced. The primary ribs become broader and flatter nearer the middle of the shell, and may be completely absent near the aperture so that the shell is smooth. Wear and exfoliation make specific identification of most of the specimens impossible, but I think that all the specimens represent one species. The shell is moderately curved near the apex; the remainder of it is straight or nearly so.

Holotype.-UO 27332.

Type locality.-UO 2538. In roadcut, 30th Ave. and Agate St., Eugene, Oreg. NW1/4 sec. 8, T. 18 S., R. 3 W. Eugene quadrangle, Eugene Formation (early and middle Oligocene). 
The longitudinal sculpture distinguishes Dentalium laneensis from other described species of the west coast Tertiary.

Localities._USGS 2723, 15264, 15278, 15310, 15310g, 15530, 15588, M3856, M3858, M3871, M3872.

Occurrence elsewhere.-Eugene Formation (early and middle Oligocene), Oregon; Wygal Sandstone Member of the Temblor Formation (late Oligocene), California.

\section{Class PELECYPODA \\ Family NUCULIDAE \\ Genus Nucula Lamarck}

Nucula Lamarck. 1799, Soc. Hist. Nat. Paris Mém., ser. 1, p. 87.

Type species.-By monotypy, Arca nuculeus Linné. Holocene, France.

Subgenus Leionucula Quenstedt

Leionucula Quenstedt, 1930, Geol. und Paläont. Abhand., Bd. 22, Heft 1, p. 112.

Type species.-By original designation, Nucula albensis d' Orbigny. Cretaceous, England and France.

Nucula (Leionucula) vokesi, $n$. sp.

Plate 8, figures $10,13,16,17$

Nucula vokesi is a small species $(5.2$ to $7.3 \mathrm{~mm}$ long and 3.7 to $6.3 \mathrm{~mm}$ high) with a smooth shell sculptured only with concentric grooves. The shell is longer than high and moderately inflated, and it has a well-defined, elongate, heart-shaped escutcheon. The shell is produced along the posterior margin and bears a faint sulcus parallel to the anterior dorsal margin; the sulcus is about $1 \mathrm{~mm}$ from the margin. The poorly preserved hinge of one right valve (pl. 8, fig. 17) shows 8 or 9 teeth preserved in the posterior series (the teeth stop at the edge of the resilifer); and 9 teeth or more preserved in the anterior series (the teeth continue above the resilifer to the beak). A left valve, also poorly preserved, shows 5 or 6 teeth in the anterior series and perhaps about 15 teeth in the posterior series that continue above the resilifer to the beak (pl. 8, fig. 16). The inner ventral margin has not been exposed.

Holotype.-Herewith designated USNM 214074 (pl. 8, fig. 10).

Type locality._USGS 18638. Type area of the Pittsburg Bluff Formation (middle Oligocene), Oregon.

The holotype is a small right valve $6.5 \mathrm{~mm}$ long and $4.7 \mathrm{~mm}$ high; the hinge is not exposed.

The resilifer is longer, and the shell is less inflated and lacks the bunched concentric threads that characterize Nucula (Leionucula) nuculana (Dall) (Dall, 1909, p. 125-126, pl. 18, fig. 2; Moore, 1963, p. $52-53$, pl. 11, figs. 2, 5, 10; pl. 12, fig. 1). Nucula hanniballi Clark (1925, p. 73-74, pl. 8, fig. 2), a species that occurs in the Blakeley Formation of Weaver (1912) (late Oligocene and early Miocene), has radial sculpture. $N$.
(Leionucula) vokesi is rare in the Pittsburg Bluff Formation.

Localities._USGS 2714, 15264, 15310, 15536, 15586, 15588, 18638.

\section{Genus Acila Adams and Adams}

Acila Adams and Adams, 1858, Genera of Recent Mollusca, v. 2, p. 545.

Type species.-By subsequent designation (Stoliczka, 1871, India Geol. Survey Mem. Palaeontologia Indica, v. 3, p. 325), Nucula divaricata Hinds. Holocene, Korea.

\section{Subgenus Truncacila Schenck}

Truncacila Schenck, 1931, in Grant and Gale, San Diego Soc. Nat. Hist. Mem., v. 1, p. 115 .

Type species.-By original designation, Nucula castrensis Hinds, Holocene, Sitka, Alaska, to San Diego, Calif.

Truncacila originated in the Cretaceous. It prefers a cool temperate habitat and depths of 5-500 fathoms (10-914 m) (Schenck, 1936, p. 33-35). Truncacila had its greatest development in the Oligocene (Schenck, 1936, p. 38). It is one of the most common fossils in the Pittsburg Bluff Formation.

Slodkewitsch (1967, p. 64) proposed Lacia, a new subgenus of Acila, with Nucula (Acila) shumardi Dall as the type species. No diagnostic features were given that validly separate the subgenus Lacia from Truncacila and the subgenus Truncacila is here retained.

\section{Acila (Truncacila) shumardi (Dall)}

Plate 8, figures 1-9, 11, 12, 14, 15, 18

Nucula (Acila) decisa Conrad. Dall, 1898, Wagner Free Inst. Sci. Trans., v. 3, pt. 4, p. 573. Dall, 1900, Wagner Free Inst. Sci. Trans., v. 3 , pt. 5, pl. 40, figs. 1, 3. Not Nucula decisa Conrad in Blake, 1855, Pacific R.R. Survey, v. 5, p. 322, pl. 3, fig. 19.

Nucula (Acila) shumardi Dall, 1909, U.E. Geol. Survey Prof. Paper 59, p. 103. Clark, 1925, California Univ. Pubs., Dept. Geol. Sci. Bull., v. 15, no. 4, p. 75 , pl. 8, fig. 11. Tegland, 1933, California Univ. Pubs., Dept. Geol. Sci. Bull., v. 23, no. 3, p. 107, pl. 5, fig. 10.

Acila shumardi Dall. Weaver, 1916a, Washington Univ. (Seattle) Pubs. Geology, v. 1, no. 1, pl. 3, fig. 43. Clark, 1918, California Univ. Dept. Geology Bull., v. 11, no. 2, p. 95, 121-122, pl. 13, figs. 7, 8, 17. Schenck and Keen, 1940, California fossils, pl. 28, fig. 2 .

Acila (Truncacila) shumardi (Dall). Schenck, 1936, Geol. Soc. America Spec. Paper 4, p. 64-67, pl. 4, figs. 5-7, 9; pl. 6, figs. 1-11, text fig. 7 (18). Weaver, 1942, Washington Univ. (Seattle) Pubs. Geology, v. 5, p. 25-26, pl. 7, figs. 5-7, 11; pl. 8, figs. 2, 5 [1943]. Hickman, 1969, Oregon Univ. Mus. Nat. Hist. Bull. 16, p. 26-27, pl. 1 , figs. $6,7,10$.

Acila shumardi is large to moderate in size (largest specimen: $30 \mathrm{~mm}$ long, $22 \mathrm{~mm}$ high, and $16 \mathrm{~mm}$ thick), and is sculptured with many narrow ribs separated by small spaces which on some specimens are barely discernible and could be described as incised lines. Secondary bifurcation of the ribs may be present at the ventral margin either in the midportion of the anterior half of the shell or along the anterior side of the primary bifurcation. On one specimen (USGS 18681) the ribs 
split near the dorsal margin on the anterior portions of both valves of an articulated specimen. Although areas of secondary bifurcation, if present, usually occur on the largest specimens, such bifurcation has also been seen on specimens of only small to moderate size. The beaks are located at the sharply truncated posterior margin. The hinges exposed on two left valves (pl. 8, figs. 4, 8) show 7-10 posterior teeth and 16-22 anterior teeth. The hinges exposed on six right valves (pl. 8, figs. 6, 9, 11, 12, 15,18 ) show $7-11$ posterior teeth and $17-20$ anterior teeth. One specimen (pl. 8, fig. 18), at the anterior end of the posterior series of teeth, shows a deep irregular socket with an irregular toothlike projection at the ventral anterior edge. The number of teeth varies with the size of the individual shell, and the larger specimens have more teeth than the smaller ones.

Holotype.-USNM 406405 (pl. 8, figs. 5, 6), figured by Dall (1900, pl. 40, figs. 1, 3). This specimen was erroneously cited as USNM 406505 by Weaver (1942, p. 26) and Schenck (1936, p. 64).

Paratypes._USNM 107402, four specimens.

Type locality.-USGS 2714, sec. 23 , T. 5 N., R. 4 W., Vernonia quadrangle, Pittsburg, Columbia County, Oreg. Pittsburg Bluff Formation, middle Oligocene.

The holotype is a right valve with the hinge exposed; the paratypes are articulated double valves and one specimen is an internal mold. A topotype from Dall's original collection is figured on plate 8 , figures $2,3,7$.

The sculpture of closely spaced ribs with narrow interstices, the size of average specimens, and the posterior truncation distinguish $A$. shumardi from other species of Acila (Truncacila).

The Acila zones of Schenck (1936, p. 41-44), like many biozones defined by single species, are not so restricted in time as some scientists supposed. Acila (Truncacila) nehalemensis (G. D. Hanna) has been collected from the Eugene Formation (early and middle Oligocene) by Hickman (1969, p. 24-25), whereas it was considered a guide fossil to beds of Keasey age (late Eocene and early Oligocene) by Schenck (1936, p. 42-44, 60-63). Acila (Acila) gettysburgensis (Reagan) occurs in beds of Blakeley age (late Oligocene and early Miocene) as well as in the Astoria Formation (Miocene), as noted by Howe (1922, p. 58), Schenck (1936, p. 80), and Moore (1963, p. 54). Acila shumardi is found in the Gries Ranch Formation of early Oligocene age, and in the Oligocene portion of the Poul Creek Formation of middle Oligocene to early Miocene age in Alaska. Acila shumardi therefore ranges from early through middle Oligocene. The genus Acila is very useful for dating because of its abundance, good preservation, distinguishing characters, and ease of collection. If its presence is used with descretion along with the presence of other species in a fauna, it is a valuable tool.

Localities._USGS 2415, 2707, 2714, 2715, 2721, 5394, 15264, 15264a, b, e, 15310, 15310a-c, e-h, 15311, 15312 , 15530, 15586, 15588, 18638, 18779, M3856, M3857, M3860, M3871, M3872, M3877, M3878.

Occurrence elsewhere.-Poul Creek Formation (middle Oligocene to early Miocene), Yakataga and Katalla Districts, Gulf of Alaska, and Stepovak Formation of Burk (1965) (early and middle Oligocene), Alaska Peninsula; Lincoln Creek Formation (late Eocene to early Miocene), Washington; Gries Ranch Formation (early Oligocene), USGS 5210, 15298, 15585, Eugene Formation (early and middle Oligocene), upper part only, Alsea Formation (early, middle, and late Oligocene), Tunnel Point Sandstone (middle Oligocene), Oregon; Tumey (early and middle Oligocene), Alegria (middle Oligocene), Kirker (middle Oligocene), and upper San Emigdio (late Eocene to middle Oligocene), Formations, California.

\section{Family NUCULANIDAE \\ Genus Litorhadia Stewart}

Litorhadia Stewart, 1930, Acad. Nat. Sci. Philadelphia Spec. Pub. 3, p. 52-53.

Type species.-By original designation, Leda acala Dall (1898, Wagner Free Inst. Sci. Trans., pt. 4, p. 586, pl. 32, fig. 3). Eocene, Wood's Bluff, Ala.

\section{Litorhadia washingtonensis (Weaver) Plate 9, figures 1-10, 12}

Leda washingtonensis Weaver, 1916a, Washington Univ. (Seattle) Pubs. Geology, v. 1, p. 34-35, pl. 3, figs. 25, 26.

Nuculana washingtonensis (Weaver). Weaver, 1942, Washington Univ. (Seattle) Pubs. Geology, v. 5, p. 38-39, pl. 8, figs. 18, 20, 26 Hickman, 1969, Oregon Univ. Mus. Nat. Hist. Bull. 16, p. 27, 30, pl. 1 , figs. 8,11 .

Leda lincolnensis Weaver, 1916a, Washington Univ. (Seattle) Pubs. Geology, v. 1, p. 35, pl. 3, figs. 23, 24.

Litorhadia washingtonensis in the collections examined attains a maximum length of $29 \mathrm{~mm}$, although it is usually a small form. It is sculptured with concentric ridges. The posterior dorsal margin is markedly concave, and the shell is produced, turning outward, along the margin of the escutcheon. The posterior end is truncated and pointed, and the anterior margin is evenly rounded. The beaks are slightly anterior to the midpoint of the shell. The right valve has 20 posterior and 26 anterior teeth; the left valve has 24 anterior and 18 posterior teeth, as counted on the two available exposed hinges. The chondrophore is long, shallow, moderately impressed, and symmetrical.

Lectotype.-CAS 451 is herewith selected as the lectotype. It is one of the two specimens cited by Weaver (1942, p. 39) as syntypes.

Type locality.-In Union Pacific Railway cut, 1/4 mile northwest of Galvin Station, in sec. 27, T. 15 N., R. 3 W., 
Malone quadrangle, Washington. Lincoln Creek Formation (late Eocene to early Miocene).

The lectotype (Weaver, 1942, pl. 8, figs. 18, 20) is a left valve with the hinge exposed and the exterior of the shell showing the concentric ridges. The shell is worn at the posterior extremity and seems to be square, whereas it was originally pointed.

Closely related forms are found in the Poul Creek (middle Oligocene to early Miocene) Formation, Yakataga District, Gulf of Alaska, and possibly in the upper Kreyenhagen Shale or Tumey Formation, California.

Localities._USGS 2714, 5394, 15264, 15264a-c, e, $15278,15310,15310 \mathrm{a}, \mathrm{g}, \mathrm{j}, 15312,15519,15530,15532$, $15537,15545,15548,15583,15586,15588,18638$, cf. M3857, M3867, M3868, cf. M3869, M3871, M3872, M3878.

Occurrence elsewhere.-Gries Ranch Formation (early Oligocene), Lincoln Creek Formation (late Eocene to early Miocene), Quimper Sandstone of Durham (1942) (early and middle Oligocene), and Blakeley Formation of Weaver (1912) (late Oligocene and early Miocene), Washington; Eugene Formation (early and middle Oligocene), Alsea Formation (early to late Oligocene), and Tunnel Point Sandstone (middle Oligocene); upper part of Brabb's (1960) Rices Mudstone Member of the San Lorenzo Formation (early Oligocene to early Miocene), California.

\section{Genus Yoldia Möller}

Yoldia Möller, 1842, Index molluscorum Groenlandiae, p. 18.

Type species.-By subsequent designation (Verrill and Bush, 1898, U.S. Natl. Mus. Proc., v. 20, no. 1139, p. 858), Yoldia arctica (Gray) = Y.hyperborea (Gould). Holocene, northern seas of Europe.

\section{Subgenus Kalayoldia Grant and Gale}

Kalayoldia Grant and Gale, 1931, San Diego Soc. Nat. Hist. Mem., v. 1, p. 128.

Type species.-By original designation, Yoldia cooperii Gabb. Miocene to Holocene, Pacific coast of the United States. Living from central California to northern Lower California, Mexico (Hertlein and Grant, 1972, p. 51).

\section{Yoldia (Kalayoldia) oregona (Shumard)}

Plate 9, figures 14, 16-18

Leda oregona Shumard, 1858, Acad. Sci. St. Louis Trans., v. 1, p. 121-122 (Reprinted in Dall, 1909, U.S. Geol. Survey Prof. Paper 59, p. 187). Gabb, 1869, California Geol.Survey, Paleontology, v. 2, p. 121.

Nuculana oregona (Shumard). Meek, 1864, Smithsonian Misc. Colln. 183, p. 5, 27. Conrad, 1866, Smithsonian Misc. Colln. 200, p. 3.

Neilo oregona (Shumard). Conrad, 1865, Am. Jour. Conchology, v. 1, p. 153.

Yoldia (Cnestrium) oregona (Shumard). Dall, 1909, U.S. Geol. Survey Prof. Paper 59, p. 105, pl. 19, fig. 4. Not Yoldia (Cnestrium) oregona (Shumard) of Dall, 1922, Am. Jour. Sci., ser. 5, v. 4, p. 310, nor
Yoldia oregona (Shumard) of Etherington, 1931, California Univ. Pubs., Dept. Geol. Sci. Bull., v. 20, p. 67, pl. 1, fig. 8.

Yoldia (Portlandia) oregona (Shumard). Weaver, 1942, (in part), Washington Univ. (Seattle) Pubs. Geology, v. 5, p. 49, pl. 9, fig. 16; not pl. 9, fig. 8.

Yoldia (Kalayoldia) oregona (Shumard). Grant and Gale, 1931, San Diego Soc. Nat. Hist. Mem., v. 1, p. 130. Trumbull, 1958, Jour. Paleontology, v. 32, no. 5, p. 900-901, pl. 115, figs. 2, 3. Moore, 1963, U.S. Geol. Survey Prof. Paper 419, p. 58, pl. 12, fig. 20. Hickman, 1969, Oregon Mus. Nat. Hist. Bull. 16, p. 31-32, pl. 1, figs. 14, 15. ?Yoldia tenuissima Clark, 1918, California Univ. Pubs. Dept. Geol. Sci. Bull., v. 11, p. 125-126, pl. 11, fig. 10; pl. 12, figs. 8, 14.

Yoldia oregona is moderate to large in size and is sculptured with concentric lines. The umbos are located medially or slightly anterior to the midline. The anterior end is evenly rounded, and the posterior end is recurved and sharply attenuated. The lectotype has about 20 teeth on the concave hinge line and about 25 teeth on the convex hinge line.

Lectotype.-USNM 562470 (designated by Trumbull, 1958, p. 900).

Type locality.-A few miles south of Oregon City, Oreg. (Oligocene).

Yoldia tenuissima Clark (1918, p. 125-126, pl. 11, fig. 10 ; pl. 12, figs. 8,14 ) is perhaps conspecific with $Y$. oregona. The poorly preserved holotype of $Y$. tenuissima seems to have a sloping anterior dorsal margin, rather than the almost straight margin of $Y$. oregona, but this is not true of a specimen subsequently figured by Clark(1925, pl. 8, fig. 5) as Y. tenuissima. Clark (1918, p. 126) differentiates the two species on the basis that $Y$. tenuissima has more posterior beaks, a somewhat more attenuate posterior end, and fewer teeth on the posterior margin.

Localities._USGS 2714, 2722, 15264, 15264e, 15310, 15310b, f, 15312, 15499, 15516, 15586.

Occurrence elsewhere.-Lincoln Creek Formation (late Eocene to early Miocene), Washington; Eugene Formation (early and middle Oligocene), Oregon.

\section{Family MYTILIDAE \\ Genus Mytilus Linné}

Mytilus Linné, 1758, Systema naturae, ed. 10, p. 704.

Type species.-By subsequent designation (Anton, 1839, Verzeichniss der conchylien welche sich in der Sammlung von H. E. Anton befinden, p. 17), Mytilus edulis Linné. Miocene to Holocene; living, cosmopolitan except in extreme tropical water (Hertlein and Grant, 1972, p. 163).

Mytilus cf. M. snohomishensis Weaver

Two small, incomplete, and poorly preserved specimens of Mytilus are in the collections. Owing to the state of their preservation, they cannot be positively identified. They are compared to Mytilus snohomishensis Weaver (1912, p. 59, pl. 13, fig. 110), a species that is found in the middle and upper Oligocene 
of Oregon and Washington and possibly also in the lower Miocene. The two specimens have terminal beaks, and the dorsal margin has a pronounced angle, possibly at about one-fourth to one-third the distance from the beak. Only the internal shell layer is preserved; it is smooth except at the ventral margin, where weak longitudinal folds can be seen.

Localities.-USGS 2714, 15586.

Occurrence elsewhere.-Of Mytilus snohomishensis: Lincoln Creek Formation (late Eocene to early Miocene), Blakeley (late Oligocene and early Miocene) and Twin River Formations (late Eocene to late Oligocene), Washington; Eugene Formation (early and middle Oligocene), Oregon.

\section{Subfamily CRENELLINAE Genus Crenella Brown}

Crenella Brown, 1827, Illus. Conchology, Great Britain, v. 1, pl. 31, figs. $12-14 ; 1844$, ed. 2 , p. 75 , pl. 23 , figs. $12-14$.

Type species.-By monotypy, Mytilus decussatus Montagu. Holocene, northern Norway.

\section{Crenella porterensis Weaver}

Plate 12, figure 12

Crenella porterensis Weaver, 1912, Washington Geol. Survey Bull. 15, pl. 14, fig. 116, Weaver, 1916a, Washington Univ. (Seattle) Pubs. Geology, v. 1, p. 36-37, pl. 3, figs. 41, 42. Tegland, 1933, California Univ. Pubs., Dept. Geol. Sci. Bull., v. 23, p. 112, pl. 6, fig. 2.

This one specimen of Crenella porterensis is incompletely exposed in rock. The preserved inner shell layers show that some of the ribs bifurcate near the ventral margin. The margin of the valves is crenulate. The shell is moderately inflated, the inner shell layers are pearly, and faint concentric lines are visible on one small portion of the shell.

Holotype.-CAS 454A.

Type locality. - In railroad cut on Union Pacific Railway 1 mile north of Galvin Station, Lewis County, Wash., sec. 27, T. 15 N., R. 3 W., Centralia quadrangle. Lincoln Creek Formation (late Eocene to early Miocene).

C. porterensis is distinguished from Crenella washingtonensis Weaver (1916a, p. 37, pl. 3, fig. 40) from the Lincoln Creek Formation by its larger size and its strong radial sculpture.

Locality._USGS 15583.

Occurrence elsewhere.-Poul Creek Formation (middle Oligocene to early Miocene), Katalla District, Gulf of Alaska; Lincoln Creek Formation (late Eocene to early Miocene) and Blakeley Formation of Weaver (1912) (late Oligocene and early Miocene), Washington; Keasey Formation (late Eocene and early Oligocene), Alsea Formation (early to late Oligocene), and possibly in the Astoria Formation (Miocene), Oregon.

\section{Family CARDITIDAE}

\section{Subfamily CARDITAMERINAE \\ Genus Cyclocardia Conrad}

Cyclocardia Conrad, 1867, Am. Jour. Conchology, v. 3, p. 191.

Type species. -By subsequent designation (Stoliczka, 1871, India Geol. Survey Mem. Palaeontologia Indica, v. 3, XX, p. 281), Cardita borealis Conrad, Holocene, eastern United States, Labrador to Cape Hatteras.

Cyclocardia (Cyclocardia) cf. C (C.) hannibali (Clark)

Plate 9, figures $11,13,15$

Cyclocardia cf. C. hannibali is a rather small carditid, subcircular in outline. It has approximately 16 to 21 rounded, slightly nodose ribs. The nodes seem to be formed by the bunching of the concentric threads that sculpture the entire shell. A rubber impression of the hinge of a left valve (pl. 9, fig. 15) shows the anterior cardinal tooth to be rather small, somewhat trigonal; and blunt. The socket posterior to this tooth shows that the opposing cardinal tooth in the right valve was straight on the anterior edge.

All the specimens of $C$. cf. $C$. hannibali are preserved as molds from one locality. The rubber impressions of these specimens show this species to be most closely related to C. hannibali (Clark) (1925, p. 88, pl. 19, figs. 6, 7). If well preserved specimens were available, they would probably prove to be conspecific.

Cyclocardia hannibali differs from $C$. hannai (Tegland), from the Blakeley Formation of Weaver (1912) (late Oligocene and early Miocene) of Washington, by having many more ribs; the ribs are a little thinner with wider interspaces but have similar sculpture. C. hannabali is distinguished from $C$. subtenta (Conrad), by narrower, higher, and more nodose ribs. The beaks seem to be higher and the anterior end more produced. C. hannibali occurs in the Astoria Formation (Miocene) of Washington and Oregon.

Locality._USGS 15537.

Occurrence elsewhere.-Of C. hannibali: Ushikubitoga Formation (Oliogocene), Japan (Kanno, 1960); Poul Creek Formation (middle Oligocene to early Miocene), Alaska; Blakeley Formation (late Oligocene and early Miocene), Washington.

\section{Family LUCINIDAE \\ Subfamily MYRTEINAE \\ Genus Lucinoma Dall}

Lucinoma Dall, 1901, U.S. Natl. Mus. Proc., v. 23, p. 806.

Type species. - By original designation, Lucina filosa Stimpson, Holocene, Grand Banks, off southeastern Canada, and northwestern United States, to Gulf of Mexico.

\section{Lucinoma columbiana (Clark and Arnold) \\ Plate 10, figures 1-8}

Phacoides columbianum Clark and Arnold, 1923, California Univ. Pubs., Dept. Geol. Sci. Bull., v. 14, p. 144-145, pl. 25, figs. 2a, 2 b. 
Clark, 1925, California Univ. Pubs., Dept. Geol. Sci. Bull., v. 15, p. 89, pl. 22, fig. 9 .

Lucina columbiana (Clark and Arnold). Weaver, 1942, Washington Univ. (Seattle) Pubs. Geology, v. 5, p. 145-146, pl. 34, figs. 13-15, 17.

Lucinoma columbiana is small to moderate in size. Both valves of the largest figured specimen are $21.2 \mathrm{~mm}$ long, $20.0 \mathrm{~mm}$ high, and $11.6 \mathrm{~mm}$ thick, but one poorly preserved specimen was at least $32 \mathrm{~mm}$ long. $L$. columbiana is inflated, subquadrate in outline with the beaks rather high, and situated anterior to the middle of the shell. L. columbiana bears closely spaced, raised concentric lamellae, and on one specimen (pl. 10, figs. 3, 7) the lamellae are more closely spaced toward the ventral margin. The anterior dorsal margin is concave, joining smoothly the rounded anterior end; the posterior dorsal margin is slightly convex, and it abruptly joins the somewhat truncated posterior end. The hinges illustrated (pl. 10, figs. 2, 6) are of a specimen that was articulated but the cardinal teeth were apparently destroyed when the valves were opened. The two valves are illustrated to show the muscle scars and the outline of the hinge. Of note are the large, heavy, seemingly flat areas posterior to the beaks on both valves, and the small node on both valves at the anterior end of the hinge. The ligament is mineralized at the dorsal edge of the posterior part of the hinges. The escutcheon is long and narrow. The lunule is moderate sized, impressed, and inequilateral, and the portion on the right valve is larger than that on the left.

Holotype.-CAS 593.

Type locality.-From sandstone and conglomerate of the Sooke Formation (early Miocene?) in the sea cliffs between the mouths of Muir and Kirby Creeks, west of Otter Point, Sooke Bay, Vancouver Island, B.C.

The Holocene species Lucinoma annulata (Reeve) is less inflated than $L$. columbiana in proportion to its size, it does not have the heavy posterior hinge plate, and it has a smaller equilateral lunule. Lucinoma acutilineata (Conrad) (1849, p. 725, pl. 18, figs. 2, 2a, 2b; Moore, 1963, p. $70-71$, pl. 15, figs. $7-10,12$ ), an early to middle Miocene species, is thinner than $L$. columbiana in proportion to its size; it has a much wider escutcheon, and it lacks the heavy flat posterior hinge plate. Lucinoma hannibali (Clark) (1925, p. 89, pl. 22, figs. 2, 4) from Weaver's (1912) Blakeley Formation (late Oligocene and early Miocene) in Washington has a wider escutcheon and less concave dorsal margin than L. columbiana.

Clark (1932) reports Lucinoma cf.L. columbiana from the Poul Creek Formation (middle Oligocene to early Miocene), Alaska.

Localities._USGS 15264, 15588, M3858.

Occurrence elsewhere.-Ushikubitoga Formation (Oligocene), Japan (Kanno, 1960); Sooke Formation (early Miocene?), Vancouver Island, B.C.; Blakeley
Formation (late Oligocene and early Miocene), Washington. Possibly in the Eugene Formation (early and middle Oligocene), the Alsea Formation (early to late Oligocene), and the Tunnel Point Sandstone (middle Oligocene), Oregon.

\section{Family UNGULINIDAE \\ Genus Felaniella Dall}

Felaniella Dall, 1899, Jour. Conchology, v. 9, no. 8, p. 244.

Type species-By original designation, Mysia (Felania) usta Gould, Holocene, Japan.

Felaniella can be distinguished externally from Diplodonta by its less prominent, centrally positioned beaks, its subquadrate outline, and its lesser inflation. Taras goodspeedi Durham and Diplodonta parilis (Conrad) probably belong in the genus Felaniella. Durham (1944, p. 145) pointed out the resemblance of $T$. goodspeedi to the Holocene species $T$. sericata, which is now assigned to Felaniella (Keen, 1958, p. 103).

\section{Felaniella (Felaniella) snavelyi, n. sp.}

Plate 10, figures 9-11

Felaniella snavelyi is subquadrangular, inequilateral, and thin-shelled; it bears the ligament in a marginal groove. The beaks are small and situated about onethird the distance from the anterior margin. The posterior dorsal margin slopes away from the beaks in a straight line at an angle of about $20^{\circ}$, and joins the rounded posterior margin abruptly; the anterior dorsal margin is shorter and a bit more rounded. One right valve has the hinge exposed (pl. 10, fig. 10) showing two cardinal teeth. The anterior tooth is moderately thick and subvertical; the posterior tooth is thick, bifid, and oblique. The pallial line seems to be doubled.

Holotype.-Herewith designated as USNM 214099, plate 10, fig. 10 .

Type locality.-USGS 15264 . On east side of Oregon State Highway 47, approximately 600 feet north of junction of Highway 47 and Scappoose-Vernonia Road $(3,500 \mathrm{ft}$ south of grid 2,660 and 5,000 ft west of grid 820 , Army Engineers Vernonia quadrangle), Columbia County, Oreg. Pittsburg Bluff Formation (middle Oligocene).

In external characters Felaniella snavelyi is identical to the living species $F$. serricata (Reeve). The shell of $F$. snavelyi is thicker, however, and the configuration of the nymph plate and ligament groove are different. The nymph plate of $F$. snavelyi is larger, heavier, and flanged along the dorsal margin, and it lacks the flattened, shallow trigonal pit that holds the resilium on $F$. serricata. The ligament groove and ligament are larger on $F$. snavelyi than on $F$. serricata.

Felaniella goodspeedi Durham (1944, p. 145) is more rounded at the anterior and posterior margins, has a higher angle between the beak and the posterior and 
anterior dorsal margins, and has more prominent beaks than $F$. snavelyi. Felaniella parilis (Conrad) (1848, p. 432; Moore, 1963, p. 71, pl. 23, fig. 9) has a more rounded anterior and posterior margin and a higher angle between the beak and the posterior and anterior dorsal margins like Felaniella griesensis (Effinger) (1938, p. 369 ).

$F$. snavelyi is rare in the Pittsburg Bluff Formation. Most of the complete specimens preserved have the mineralized ligament intact.

Localities.-USGS 2714, 15264, 15310, 15312, 15516, 15537, 15544, 15586, M3858, M3871.

\section{Family CARDIIDAE Subfamily PROTOCARDIINAE \\ Genus Nemocardium Meek}

Nemocardium Meek, 1876, U.S. Geol. Survey Territories, v. 9, p. 167-168.

Type species.-By subsequent designation (Sacco, 1899, I. Moll. Liguria, pt. 27, p. 56), Cardium semiasperum Deshayes. Eocene, France.

\section{Subgenus Keenaea Habe}

Keenaea Habe, 1951, Genera of Japanese Shells: Pelecypoda, no. 2, p. 152.

Type species.-By original designation, Nemocardium samarangae Makiyama. Holocene, Japan.

Nemocardium (Keenaea) lorenzanum (Arnold)

Plate 10, figures 12-14

Cardium cooperii Gabb var. lorenzanum Arnold, 1908, U.S. Natl. Mus. Proc., v. 34, p. 366, pl. 33, fig. 6; 1909, U.S. Geol. Survey Geol. Atlas, Santa Cruz Folio, p. 4, fig. 17.

Cardium lorenzanum Arnold. Tegland, 1933, California Univ. Pubs., Dept. Geol. Sci. Bull., v. 23, p. 116-117, pl. 7, figs. 16, 17.

Nemocardium lorenzanum (Arnold). Weaver, 1942, Washington Univ. (Seattle) Pubs. Geology, v. 5, p. 160, pl. 35, fig. 22, pl. 36, figs. 3,5 .

Nemocardium (Keenaea) lorenzanum (Arnold). Keen, 1954, Am. Paleontology Bull., v. 35, no. 153, p. 11. Hickman, 1969, Oregon Univ. Mus. Nat. Hist. Bull. 16, p. 38, pl. 2, fig. 7.

Nemocardium lorenzanum is a small form in the Pittsburg Bluff Formation; the length of the largest specimen in the collections is $18.3 \mathrm{~mm}$, but most of the specimens are about $10 \mathrm{mmm}$ long. $N$. lorenzanum is subquadrate in outline, is moderately inflated, and has prominent beaks. The hinge is not exposed. The shell is very thin. The well-developed posterior ridge demarcates the change in ribbing: the anterior portion bears flat small radial ribs separated by finely incised lines; the posterior portion bears narrow high ribs that are separated by interspaces almost as wide that bear a secondary concentric sculpture. This concentric sculpture is between the ribs and at right angles to them, and it consists of raised, thin, ridgelike intercalations that are evenly spaced but commonly not alined.

Holotype.-USNM 165444.
Type locality.-In cliff in north bank of Chehalis River, at the town of Porter, Grays Harbor County, Wash. In sec. 22, T. 17 N., R. 4 W., Malone quadrangle. Lincoln Creek Formation (late Eocene to early Miocene).

This species is distinguished by its subquadrate outline and by its sculpture of more than 60 flat-topped ribs anterior to the posterior ridge and a few more than 25 narrow high ribs posterior to the posterior ridge.

Closely related forms occur in the Poul Creek Formation (middle Oligocene to early Miocene), Yakataga District, Gulf of Alaska, and in Burk's (1965) Stepovak Formation (early and middle Oligocene), McGinty Point section, Alaska.

Localities._USGS 15264, 15278, 15310, 15530, 15537, 15548, 18638, M3873.

Occurrence elsewhere.-Lincoln Creek Formation (late Eocene to early Miocene) and Weaver's (1912) Blakeley Formation (upper Oligocene and lower Miocene), Washington; Eugene Formation (lower and middle Oligocene), Alsea Formation (early, middle, and late Oligocene), Keasey Formation (late Eocene and early Oligocene), Oregon; upper part of Brabb's (1960) Rices Mudstone Member of San Lorenzo Formation (late Eocene to middle Oligocene), California.

\section{Family VENERIDAE \\ Subfamily PITARINAE \\ Genus Pitar Römer}

Pitar Römer, 1857, Krit. Unters. Art. Moll., Venus, p. 15.

Type species.-By monotypy, Venus tumens Gmelin. Holocene, West Africa.

\section{Pitar (Pitar) dalli (Weaver)}

Plate 12, figures 1, 2, 4

Pitaria dalli Weaver, 1916a, Washington Univ. (Seattle) Pubs. Geology, v. 1, p. 41, pl. 1, figs. 1-4. Tegland, 1929, California Univ. Pubs., Dept. Geol. Sci. Bull., v. 18, p. 278, pl. 21, figs. 4-9.

Pitar dalli (Weaver). Weaver, 1942, Washington Univ. (Seattle) Pubs. Geology, v. 5, p. 181-182, pl. 43, figs. 1-5, 8, 11. Hickman, 1969, Oregon Univ. Mus. Nat. Hist. Bull. 16, p. 46-47, pl. 3, figs. 16-19, pl. 5 , figs. 2,5 .

An internal mold of one almost complete large specimen is subovate in outline and moderately inflated. The few small internal molds are also subovate in outline but are less inflated. On one of these molds, the beaks are very close to the anterior margin; on all the others, they are about a third of the distance from the anterior end. One incomplete left hinge is figured (pl. 12, fig. 2).

Syntypes.-CAS 460A, 460C, 460D.

Type locality.-In railroad cut on Union Pacific Railway 1 mile north of Galvin Station, Lewis County, Wash. Sec. 27, T. 15 N., R. 3 W., Centralia quadrangle. Lincoln Creek Formation (late Eocene to early Miocene). 
Localities._USGS 15278, 15310, 15310a, 15499, 15516, 15532, 15537, 15548, M3873; cf. 15519.

Occurrence elsewhere.-Poul Creek Formation (middle Oligocene to early Miocene), Yakataga and Katalla Districts, Gulf of Alaska; Lincoln Creek Formation (late Eocene to early Miocene) and the Marrowstone Shale of Durham (1944), Washington; Eugene Formation (early and middle Oligocene), Alsea Formation (early to late Oligocene), Tunnel Point Sandstone (middle Oligocene), Oregon; Tumey Formation of Atwill (1935) (early and middle Oligocene), California.

\section{Genus Callista Poli}

Callista Poli, 1791, Testacea utriusque Siciliae, eorumque historia et anatomia, tome 1, p. 30.

Type species.-By subsequent designation, Venus chione Linné (Meek, 1876). Holocene Mediterranean.

\section{Subgenus Macrocallista Meek}

Macrocallista Meek, 1876, U.S. Geol. Survey Territories, v. 9, p. 179.

Type species.-By monotypy, Venus gigantea Gmelin = Venus nimbosa Lightfoot. Holocene, Caribbean.

The mature specimens of Callista have much more massive hinge plates and all the teeth are larger than on specimens of Macrocallista of similar size; this is not true of juvenile specimens of Callista. Macrocallista is much more produced anteriorly, is less inflated, and has a thinner shell than Callista. The configuration and arrangement of teeth on both valves of Macrocallista so closely resembles that of Callista that it does not seem proper to separate Macrocallista except subgenerically. Placing Macrocallista as a subgenus of Callista helps to show the close relation within this difficult and variable group.

The hinge of Callista (Macrocallista) pittsburgensis differs from that of the type species of Macrocallista, Venus nimbosa Lightfoot. The hinge of $C$. (M.) nimbosa is here described in order that the differences can be noted and the reasons for retaining $C$. (M.) pittsburgensis in Macrocallista understood.

In the following description, the right valve is considered to have two anterior laterals, three cardinals, and a posterior lateral; the left valve is considered to have one anterior lateral and three cardinals.

The right valve of Callista (Macrocallista) nimbosa has the two anterior laterals bordering a socket that receives the left anterior lateral. The right anterior laterals are smooth and rounded, the dorsal one is clearly defined with a slight pointed prominence at the anterior end. The ventral lateral is a thick, rather even swelling projecting a bit over the socket and perhaps, if strictly defined, is not a lateral tooth. The right anterior cardinal, the most prominent tooth, projects beyond all the others. It is thickest at the ventral end, and it thins and curves towards the anterior at the dorsal margin. The posterior edge of the tooth nearly parallels the anterior side of the middle cardinal. The right middle cardinals form a very deep socket between their nearly parallel surfaces. The right posterior cardinal is thinner than the other two cardinals and is pointed at about midpoint. It parallels the posterior lateral tooth. The right posterior cardinal is not grooved in the strict sense of the word, but has a flange that looks like a deformity. However, examination of 11 right valves of $C$. (M.) nimbosa has shown that the posterior cardinal on all right valves has an anterior flange. The right posterior cardinal consistantly shows a slight groove along the anterior side at the highest part of the tooth, with the part of tooth anterior to the groove lower than the posterior part. The right posterior lateral is thin and bladelike.

The anterior lateral of the left valve of $C$. (M.) nimbosa is a prominent, somewhat triangular, pointed projection. The anterior cardinal is very thin except at the ventral margin where it thickens; its anterior edge is flat and almost perpendicular to the beak. The middle cardinal is thick and curved with the thickest portion at the ventral end. The posterior cardinal, which resembles a lateral tooth, is thin, bladelike, and long. It extends along the dorsal margin to a point just above the middle cardinal tooth where it forms a socket to receive the right posterior cardinal.

\section{Callista (Macrocallista) pittsburgensis Dall}

Plate 12, figures 3, 5-11, 13

Callista pittsburgensis Dall, 1900, Wagner Free Inst. Sci. Trans., v. 3, pt. 5, pl. 36, fig. 22.

Meretrix (Callista) pittsburgensis Dall, 1900, Wagner Free Inst. Sci. Trans., v. 3, pt. 5, pl. 43, fig. 15.

Macrocallista pittsburgensis (Dall). Dall, 1903, Wagner Free Inst. Sci. Trans., v. 3, pt. 6, p. 1253. Clark, 1918, California Univ. Dept. Geology Bull., v. 11, p. 146. Clark, 1925, California Univ. Pubs., Dept. Geol. Sci. Bull., v. 15, p. 92, pl. 18, fig. 9; pl. 19, figs. 4, 5. Clark, 1932, Geol. Soc. America Bull., v. 43, p. 816, pl. 19, figs. 1, 2. Weaver, 1942, Washington Univ. (Seattle) Pubs. Geology, v. 5, p. 175-176, pl. 32, fig. 7; pl. 41, figs. 4, 7, 10, 14. Hickman, 1969, Oregon Univ. Mus. Nat. Hist. Bull. 16, p. 43, pl. 3, figs. 8-14.

Callista pittsburgensis is of moderate size, subovate in outline, and sculptured with bunched concentric lines. It is elongate posteriorly with a subdued angulation; the anterior end is evenly rounded. The beaks are situated one-fourth to one-fifth the distance from the anterior end. The shell is usually brown; Dall (1903, p. 1253) attributed this to the preservation of the periostracum, which seems reasonable considering the tight adherence of the periostracum on Holocene species. A few specimens lack the subdued posterior angulation and are higher in proportion to length than the average specimen (pl. 12, fig. 8). These specimens are considered to represent normal variation within the species. The external ligament platform is commonly preserved. The elongate lunule is demarcated by an incised line; it is smooth because the concentric lines sculpturing the rest 
of the shell do not cross it. The hinge of $C$. pittsburgensis differs from the type species of Macrocallista, $C$. nimbosa. The posterior cardinal tooth of the right valve of $C$. pittsburgensis is deeply grooved, whereas this tooth of C. nimbosa is not grooved; instead it has a small flange on the anterior side. The middle and anterior right cardinals slant toward the anterior end rather than being perpendicular to the beak; the socket bordered by the two anterior laterals is not parallel to the dorsal hinge margin, and both the anterior laterals are more prominent on $C$. pittsburgensis than on $C$. nimbosa. The left valve of $C$. pittsburgensis has an anterior lateral that is smaller, thinner, and less prominent than on C. nimbosa; the anterior cardinal is not perpendicular to the beak but slants toward the anterior margin; the middle cardinal projects over the ventral edge of the hinge plate and seems to be very slightly grooved; the anterior cardinal is essentially similar to that of $C$. nimbosa. In both valves of $C$. pittsburgensis, the hinge plate and attendant dentition in specimens of similar size are more restricted to the area below the beak. The anterior end of the shell of $C$. nimbosa is much more produced. Perhaps the most striking difference between the hinges of the two species is the grooved right posterior cardinal of $C$. pittsburgensis. C. hornii (Gabb) from the Eocene of California (Stewart, 1930, pl. 17, fig. 7) and $C$. cathcartensis (Weaver) from the late Oligocene and early Miocene of Washington have a grooved right posterior cardinal.C. densa Moody (1916, p. 58) from the Pliocene of California is said to have bifid posterior cardinals in both valves. Although the differences between $C$. pittsburgensis and $C$. nimbosa are considered significant, it is my opinion that they could be the result of the evolution of the genus, and that the Pitarinae need much more study before it would be practical to propose, if necessary, a new subgeneric name.

Lectotype.-USNM 107396 is herewith designated the lectotype (pl. 12, fig. 13). The lectotype is one of the two specimens originally figured by Dall $(1900, \mathrm{pl}$. 36 , fig. 22). The figured paratype (pl. 12, fig. 11) has been assigned catalogue number USNM 107399.

Type locality._Pittsburg, Columbia County, Oreg. Sec. 23, T. 5 N., R. 4 W., Vernonia quadrangle. Pittsburg Bluff Formation (middle Oligocene).

The posterior elongation and anterior location of the beaks of $C$. pittsburgensis separate it from other species. Locally very abundant, it occurs in great numbers in some rocks with only a few other forms intermingled but with no apparent life orientation. The mineralized ligament is preserved on some specimens (M3858).

Localities._USGS 2714, 5394, 15264, 15264a, b, e, 15310, 15310a, c, f, g, j, i, 15311, 15519, 15530, 15537,
$15545,15583,15586,15588,18638,21612$, M3856, M3857, M3858, M3867, M3868, cf. M3869, M3871, M3872, M3878.

Occurrence elsewhere.-Poul Creek Formation (middle Oligocene to early Miocene), Alaska; Lincoln Creek Formation (late Eocene to early Miocene), Washington; Alsea Formation (early to late Oligocene), Eugene Formation (early and middle Oligocene), and Tunnel Point Sandstone (middle Oligocene), Oregon; Kreyenhagen Shale (Eocene and early Oligocene), Kirker Tuff (middle and late Oligocene), California. Possibly in Alegria Formation (middle Oligocene), California.

\section{Family MACTRIDAE}

Genus Spisula Gray

Spisula Gray, 1837, Mag. Nat. Hist., new ser., v. 1, p. 372

Type species-By subsequent designation (Gray, 1847, Zool. Soc. London Proc., no. 179, p. 185), Mactra solida Montagu $=$ Cardium solidum Linné. Holocene, Atlantic.

\section{Subgenus Mactromeris Conrad}

Mactromeris Conrad, 1868, Am. Jour. Conchology, v. 3, app., pt. 3, p. 45.

Type species. - By subsequent designation (Stoliczka, 1871, Geol. Survey India, Palaeontologia Indica, ser. 6, v. 3, p. 16), Mactra ovalis Gould, Holocene, North Atlantic.

Spisula (Mactromeris) pittsburgensis Clark Plate 14, figures 3-8, 10, 11

Spisula pittsburgensis Clark, 1925, California Univ. Pubs., Dept. Geol. Sci. Bull., v. 15, p. 101-102, pl. 17, figs. 2, 4. Tegland, 1933, California Univ. Pubs., Dept. Geol. Sci. Bull., v. 23, p. 120-121. Weaver, 1942, Washington Univ. (Seattle) Pubs. Geology, v. 5, p. 235, pl. 54, fig. 9; pl. 61, figs. 1, 4. Hickman, 1969, Oregon Univ. Mus. Nat. Hist. Bull. 16, p. 51, pl. 5, fig. 1 .

Spisula pittsburgensis is subovate in outline, small to moderate sized, and thin shelled. The posterior dorsal margin is straight except for a slightly inflated escutcheon. The posterior end is evenly rounded. A ridge extends from the umbo to the posterior ventral margin. The anterior dorsal margin is inflated in the lunule area; the anterior end is slightly pointed. There is little variation in size, outline, and degree of inflation in this species.

The right anterior cardinal is thin, bladelike, and protrudes well beyond the hinge plate; it is fused to the dorsal margin of the shell. The right posterior cardinal is thin, does not protrude as far as the anterior cardinal, and borders the anterior end of the resilifer, which is moderately deep and oblique. The anterior and posterior paired laterals are thin; each are bordered with a moderately shallow dorsal pit and separated from one another by a very deep pit. The left cardinal has the shape of an inverted $\mathrm{V}$, is small, and projects far beyond the hinge plate. The single anterior and posterior 
laterals are thin, the posterior one bladelike, the anterior one rounded and more produced.

Holotype. - SU 5205.

Type locality.-UW 476. From bluffs along highway near old mill at Pittsburg, Columbia County, Oreg. Pittsburg Bluff Formation (middle Oligocene).

Spisula eugenensis differs from $S$. pittsburgensis by having an anterior umbonal ridge (Hickman, 1969, p. $50-51$ ).

Localities._USGS 2714, 5394, 15264, 15264a-e, 15310, 15310a-f, i, 15311, 15312, 15499, 15532, 15545, 15586, 15588, 18638, M3856, M3858, M3860, M3869, M3871, M3872, M3877, M3878.

Occurrence elsewhere.-Poul Creek Formation (middle Oligocene to early Miocene), Yakataga District, Gulf of Alaska; Quimper Sandstone of Durham (1942) (early and middle Oligocene) and Blakeley Formation of Weaver (1912) (late Oligocene and early Miocene), Washington; Alsea Formation (early to late Oligocene), Eugene Formation (early and middle Oligocene), Tunnel Point Sandstone (middle Oligocene), Oregon.

Spisula (Mactromeris?) veneriformis Clark

Plate 14, figures 1, 2, 9

Spisula veneriformis Clark, 1925, California Univ. Pubs., Dept. Geol. Sci. Bull., v. 15, p. 103, pl. 16, figs. 1-3. Weaver, 1942, Washington Univ. (Seattle) Pubs. Geology, v. 5, p. 235, pl. 54, fig. 9; pl. 61, figs. 1, 4.

Clark describes the hinge of this species as follows:

Hinge plate rather heavy; resilifer pit deep, the two cardinals in the right valve well developed, both reaching nearly across hinge plate; anterior cardinal close to and connected with anterior dorsal margin. Cardinal in right valve apparently not deltoid. The deltoid tooth is a character common to almost all genera of the Mactridae; but in this species the cardinal consists of one heavy process extending from a beak to anterior edge of hinge plate.

Keen (1969, p. N595) describes the hinge of the Mactracea as having one inverted V-shaped cardinal tooth in the left valve and two cardinals in the right valve.

The right valve is here considered to have two cardinal teeth, rather than one deltoid tooth. The few specimens of Spisula veneriformis in the collections are internal molds with no shell remaining. Rubber impressions were made of all specimens retaining a mold of the hinge. An impression of a right valve was obtained (pl. 15, fig. 2), and although the impression is not perfect, the right valve may have had two cardinal teeth originally. In examining Holocene specimens of Spisula (Mactromeris) in the collections, I found that in at least half the specimens of right valves the posterior cardinal was either completely destroyed or broken. Perhaps when the valves of this form are disarticulated, the fragile right posterior cardinal is destroyed. This may be the explanation for Clark (1925, p. 103) saying that the right valve had but one tooth.

Holotype.-UCMP 54.
Type locality._SU N.P. 42. In shale and sandstone in sea cliff at Tunnel Point, west of Coos Bay, Oreg. Tunnel Point Sandstone (middle Oligocene).

This species is very large and shaped more like a venerid than a mactrid. The beaks are high and about a third the distance from the anterior margin. The venerid outline distinguishes $S$. veneriformis from other species of Spisula.

Localities._USGS 15516, 15532, 15537, 15544, 15588 .

Occurrence elsewhere.-Tunnel Point Sandstone (middle Oligocene), Oregon.

\section{Family MESODESMATIDAE Subfamily DAVILINAE Genus Ervilia Turton}

Ervilia Turton, 1822, British Bivalves, p. 56.

Type species.-Mya nitens Montagu. Holocene, Florida.

\section{?Ervilia oregonensis Dall}

Plate 16, figures 2, 5

Ervilia oregonensis Dall, 1898, Wagner Free Inst. Sci. Trans., v. 3, pt. 4, p. 916, pl. 33, fig. 16. Weaver, 1942, Washington Univ. (Seattle) Pubs. Geology, v. 5, p. 243, pl. 56, fig. 4.

The single specimen is presumably conspecific with Ervilia oregonensis Dall. The hinge, though exposed, is not sufficiently well preserved for generic identification. The specimen is more quadrate in outline than the Holocene specimens of Ervilia. The shell is very thin and concentrically sculptured, and the ligament is presumably obsolete.

Holotype.-USNM 107406.

Type locality.-Nehalem River, Columbia County, Oreg. Presumably from the Pittsburg Bluff Formation, middle Oligocene.

Locality._USGS 18638.

Family TELLINIDAE
Subfamily TELLININAE
Genus Tellina Linné

Tellina Linné, 1758, Systema naturae, ed. 10, p. 674.

Type species.-By subsequent designation (Schmidt, 1818, Versuch Conchylien-Sammlung, p. 51, 177), Tellina radiata Linné. Holocene, West Indies.

\section{Subgenus Eurytellina Fischer}

Eurytellina Fischer, 1887, Man. de Conchyliologie et de Paleont. Conch., p. 1147.

Type species-By monotypy, Tellina punicea Born. Holocene, West Indies.

Tellina (Eurytellina) aduncanasa Hickman

Plate 11, figures 7-12

Tellina aduncanasa Hickman, 1969, Oregon Univ. Mus. Nat. Hist. Bull. 16, p. 55-56, pl. 6, figs. 7-12.

Tellina aduncanasa is of moderate size and elongate; the length about twice the height. The anterior end is evenly rounded, the posterior end sharply attenuated. The posterior end is strongly beveled and set off by a 
ridge at the anterior side. The entire surface bears fine incised lines that change direction at the anterior edge of the beveled part, making an angle of about $90^{\circ}$. Hickman (1969, p. 56) describes the hinge of both valves.

Holotype.-UO 27262.

Type locality.-UO 2567. In well-indurated brownish-gray tuffaceous sandstone and siltstone on east side of Oregon State Highway 47, 0.2 mile north of junction with Pittsburg-Scappoose Road, N1/2 sec. 23, $\mathrm{T}$. 5 N., R. 4 W., Vernonia quadrangle, Columbia County, Oreg. Pittsburg Bluff Formation, (middle Oligocene).

Localities._USGS 2714, 2722, 15264, 15264b, c, e, 15310, 15310b, 15312, 15544, 15586, 15588, M3858; cf. 15311.

Occurrence elsewhere.-Eugene Formation (early and middle Oligocene), Oregon.

\section{Tellina? pittsburgensis Clark \\ Plate 11, figures 1-6}

Tellina pittsburgensis Clark, 1925, California Univ. Pubs., Dept. Geol. Sci. Bull., v. 15, p. 95, pl. 12, figs. 8, 9. Weaver, 1942, Washington Univ. (Seattle) Pubs. Geology, v. 5, p. 200-201, pl. 48, fig. 4. Hickman, 1969, Oregon Univ. Mus. Nat. Hist. Bull. 16, p. 55, pl. 6, figs. 3-6.

Tellina? pittsburgensis is of small size, subovate in outline, and very thin shelled. The anterior end is evenly rounded and the posterior end is slightly produced. The shell bears fine, bunched concentric lines that are deflected near the posterior end. Just anterior to this deflection is a slight sulcus. The shell is moderately inflated. The left valve is slightly larger than the right, and both valves are deflected to the right at the posterior end.

Holotype.-SU Paleo. Type Coll. 46.

Type locality._SU loc. NP 5. In sandstone cliff along Nehalem River near old Pittsburg lumber mill, just past bridge below Vernonia, Oreg. Pittsburg Bluff Formation (middle Oligocene).

Because of the state of preservation of the specimens, the small size of the species, and the very thin shell, it has not been possible to prepare a perfect hinge. Several hinges were exposed and two are figured (pl. 11, figs. 1, 2) but still some details are not clear. No lateral teeth could be identified without qualification, although there is a suggestion of a lateral tooth on one of the valves. Hickman (1969, p. 55) found well-developed lateral teeth on specimens identified as $T$. pittsburgensis from the Eugene Formation. Her findings suggest that the specimens from the Eugene Formation may not be conspecific with the Pittsburg Bluff specimens. The following characters were noted on the hinges exposed: On the right valve there are two cardinal teeth, the posterior one thick and bifid, the anterior one very small and thin. A possible lateral tooth is posterior to the cardinals but near them; no lateral tooth was found anterior to the cardinals. On the left valve are two cardinal teeth, the posterior thick and bified and the anterior one very small and thin. A possible lateral tooth is anterior to the cardinal teeth.

A closely related form occurs in the Poul Creek Formation (middle Oligocene to early Miocene), Yakataga and Katella Districts, Gulf of Alaska.

Localities.-USGS 2714, 15264, 15264b, c, 15310, 15310d, 15519, 15530, 15586, 15588, 18638, M3871, M3877, cf. M3878.

Occurrence elsewhere.-Gries Ranch Formation (early Oligocene), Quimper Sandstone of Durham (1942) (early and middle Oligocene), Washington; Eugene Formation (early and middle Oligocene) and Tunnel Point Sandstone (middle Oligocene), Oregon; Tumey Formation of Atwill (1935) (Oligocene), California.

\section{Family SOLENIDAE \\ Genus Solen Linné}

Solen Linné, 1758, System naturae, ed. 10, p. 672.

Type species.-By subsequent designation (Schumacher, 1817, Essai d'un nouveau système des habitations des vers testacès, p. 124, pl. 6, fig. 3), Solen vagina Linné. Holocene, Europe.

\section{Solen townsendensis Clark \\ Plate 13, figures 3-5}

Solen (Plectosolen) townsendensis Clark, 1925, California Univ. Pubs., Dept. Geol. Sci. Bull., v. 15, p. 97-98, pl. 22, figs. 7, 10.

Solen townsendensis Clark. Effinger, 1938, Jour. Paleontology, v. 12, p. 372-373. Weaver, 1942, Washington Univ. (Seattle) Pubs. Geology, v. 5, p. 225, pl. 53, figs. 1, 9 .

?Solen sicarius Gould. Hickman, 1969, Oregon Univ. Mus. Nat. Hist. Bull. 16, p. 63-64, pl. 8, figs. 5, 7, 9 .

Solen townsendensis is thin shelled. The few specimens in the collections are small. The anterior end is truncated at the dorsal margin and evenly rounded at the ventral margin. It lacks a sulcus but it has a slight broad depression. The posterior end is almost evenly rounded with a slight flattening in the midregion of the shell.

Holotype.-SU 51.

Type locality._SU Loc. NP 272. In bluffs along Skamokawa River above big bend 1 mile east of junction of main and middle forks, Skamokawa, Wash. Gries Ranch Formation (early Oligocene).

Hickman (1969, p. 63-64) assigned an Oligocene Solen from the Eugene Formation (early and middle Oligocene), Oregon, to the Miocene to Holocene species Solen sicarius Gould, because she felt it impossible to determine the affinities of the fossil species without intensive study. One well-preserved specimen in the Pittsburg Bluff collections (pl. 8, figs. 10, 11) makes some comparison with $S$. sicarius possible. In the ratio of height to length, the fossil form is identical to $S$. 
sicarius. However, both the anterior and posterior ends of $S$. townsendensis are rounded as in Solen rosaceus Carpenter, a Holocene species, rather than truncated as in $S$. sicarius. $S$. rosaceus is much more elongate in proportion to height than the Oligocene species. It seems probable that the Oligocene species is not conspecific with the Holocene forms examined, and the name Solen townsendensis is retained for the fossil form.

Solen conradi Dall (1900, p. 953), a Miocene species, has a concave dorsal margin and is more sharply truncated at the posterior end than $S$. townsendensis.

Localities.-USGS 2714, 5394, 15264, 15310, 15537, 15586, M3858, M3860, M3871, M3872.

Occurrence elsewhere.-Gries Ranch Formation (early Oligocene), Quimper Sandstone of Durham (1942) (early and middle Oligocene), Washington; Alsea Formation (early to late Oligocene) and possibly in the Eugene Formation (early and middle Oligocene) and the Tunnel Point Sandstone (middle Oligocene), Oregon.

\section{Genus Solena Mörch}

Solena Mörch, 1853, Cat. Conch. Yoldi, pt. 2, p. 7.

Type species.-By subsequent designation (Stoliczka, 1871, Geol. Survey India, Palaeontologia Indica, ser. 6, p. xvi), Solen obliquus Spengler. Holocene, Caribbean.

Subgenus Eosolen Stewart

Eosolen Stewart, 1930, Acad. Nat. Sci. Philadelphia Spec. Pub. 3, p. 290-291.

Type species.-By original designation, Solen plagiaulax (Cossmann). Middle Eocene, France.

On the basis of a distinct umbonal furrow, Solena (Eosolen) columbiana (Weaver and Palmer) (1922, p. 24, pl. 10, fig. 3) was placed in Eosolen by Stewart (1930, p. 292). The following species should also be assigned to this subgenus:

Solena lincolnensis (Weaver), 1916a, p. 43, pl. 2, figs. 9-12, Oligocene, Washington.

Solena clarki (Weaver and Palmer), 1922, p. 23-24, pl.

9, fig. 16, Eocene, Washington.

Solena eugenensis (Clark), 1925, p. 98, pl. 22, fig. 1, Oligocene, Oregon.

\section{Solena (Eosolen) eugenensis (Clark)}

Plate 13, figures $1,2,6$

Solen eugenensis Clark, 1925, California Univ. Pubs., Dept. Geol. Sci. Bull., v. 15, p. 98 , pl. 22, fig. 1.

Solena eugenensis (Clark). Weaver, 1942, Washington Univ. (Seattle) Pubs. Geology, v. 5, p. 230, pl. 53, figs. 14, 15.

Solena (Eosolen) eugenensis (Clark). Hickman, 1969, Oregon Univ. Mus. Nat. Hist. Bull. 16, p. 63, pl. 7, figs. 11, 12.

Solena eugenensis is a large moderately thick-shelled form with a strong anterior sulcation. The shell flares outward at the anterior gape. The anterior margin is truncated at an angle of about $30^{\circ}$ from the perpendicular; the posterior angulation is nearly perpen- dicular. The shell is smooth except for bunched concentric lines. Parts of the mineralized ligament are preserved on some specimens.

Holotype.-UCMP 30338.

Type locality.-UC 4182. New City Reservoir, Eugene, Oreg. Eugene Formation (early and middle Oligocene).

Solena eugenensis is higher in proportion to length and has a lower anterior angulation than S. lorenzana Wagner and Schilling (1923, p. 256, pl. 47, fig. 1) from the Oligocene of California.

A closely related form occurs in the Poul Creek Formation (middle Oligocene to early Miocene), Alaska.

Localities.-USGS 2714, 5394, 15264b, 15278, $15310 \mathrm{a}, 15312$, 15499, 15519, 15529, 15537, 15544, 15586, 15588, M3858, M3867, M3868, M3872; cf. M3871, cf. M3878.

Occurrence elsewhere.-Lincoln Creek Formation (late Eocene to early Miocene), Washington; Eugene Formation (early and middle Oligocene), and possibly in the Alsea Formation (early to late Oligocene) and in the Tunnel Point Sandstone (middle Oligocene), Oregon.

\section{Family HIATELLIDAE \\ Genus Panopea Ménard de la Groye}

Panopea Ménard de la Groye, 1807, Mémoire sur un nouveau genre de coquille bivalve-équivalve de la famille des Solenoides, p. 16, 31 (Dall, 1912, Malacological Soc. Proc., v. 10, p. 34-35). Vokes (1967, p. 326) cites Panopea Ménard de la Groye (April?, 1807) as the nomenclatorially valid name predating Panope Ménard de la Groye (August, 1807). A decision of the I.C.Z.N. for the emended spelling, Panope, is pending.

Type species.-By subsequent designation (Schmidt, 1818, Versuch Conchylien-Sammlung, p. 47, 177), Mya glycimeris Born (cited by Ménard de la Groye, 1807, p. 32 , in synonymy of Panope aldrovandi). Holocene, Mediterranean Sea.

\section{Panopea snohomishensis Clark}

Plate 15, figure 5

Panope snohomishensis Clark, 1925, California Univ. Pubs., Dept. Geol. Sci. Bull., v. 15, p. 105, pl. 10, fig. 2. Weaver, 1942, Washington Univ. (Seattle) Pubs. Geology, v. 5, p. 261-263, pl. 59, figs. 3, 10.

Panopea snohomishensis is moderate sized, subovate, and high in proportion to length. The anterior end is evenly rounded and the posterior end is attenuated and evenly rounded to moderately truncated (pl. 15, fig. 5). The posterior end is smaller than the anterior end. The beaks are slightly anterior of the midportion of the shell. The hinge line is not straight; instead it slopes from the beaks to the anterior and posterior ends of the shell and thus is not parallel to the ventral margin. The beaks are prominent and small. The hinge is not exposed.

Holotype.-SU 59. Paratype SU 60.

Type locality.-SU loc. N.P. 146. In Northern Pacific Railway cut one-half mile north of Cathcart Station, 
Snohomish County, Wash. sec. 6, T. 27 N., R. 6 E., Maltby quadrangle, Lincoln Creek Formation (late Eocene to early Miocene).

This species is distinguished by its subovate outline, the slope of the dorsal margin, and the large anterior end.

Panopea cf. $P$. snohomishensis is reported from the Poul Creek Formation (middle Oligocene to early Miocene), Alaska.

Localities.-USGS 15264, 15516.

Occurrence elsewhere.-Lincoln Creek Formation (late Eocene to early Miocene), Washington; Alsea Formation (early to late Oligocene) Oregon.

\section{Panopea ramonensis Clark Plate 15, figures 1-3}

Panope ramonensis Clark, 1925, California Univ. Pubs., Dept. Geol. Sci. Bull., v. 15, p. 106, pl. 10, figs. 2, 3. Weaver, 1942, Washington Univ. (Seattle) Pubs. Geology, v. 5, p. 263-264, pl. 59, fig. 11. Hickman, 1969, Oregon Univ. Mus. Nat. Hist. Bull. 16, p. 65, 68, pl. 8, figs. 8, 12 .

Panopea ramonensis is elongate and subquadrate in outline. The hinge line is straight and parallels the ventral margin. The posterior and anterior ends are of equal size; the posterior end is broadly truncated and gaping and the anterior end is evenly rounded. The beaks are small but prominent, inturned, and anterior of the midpoint of the shell. In his original description, Clark (1925, p. 106) says, "A fairly broad, shallow depression or sinus between beak and lower angle of truncated posterior end; this zone of depression more noticeable on some specimens than on others." In the Pittsburg Bluff collections, the specimens with the shell intact do not show this sinus, whereas those from which the shell has exfoliated do. It seems possible that this sinus is simply the impression left at the boundary where thickened shell which forms the hinge line meets the thinner shell. Modeling clay was pressed into the shell of a Holocene specimen of Panopea abrupta and a "sinus" was produced on the clay similar to that seen on internal molds of $P$. ramonensis. $P$. ramonensis is more elongate in proportion to height and is much smaller than $P$. abrupta. It differs from $P$. snohomishensis by having a straight hinge line and a medially located beak.

Holotype._UCMP 30330. Paratype: UCMP 30331.

Type locality.-UC loc. 1131. One-half mile southwest of town of Walnut Creek, on east side of OaklandAntioch Railway bridge, elevation 150 feet, Contra Costa County, Calif. San Ramon Sandstone (early Miocene?).

Localities.-USGS 2714, 15310, 15310e, 15312, 15499, 15519, 15586, 15588, M3871, M3872.

Occurrence elsewhere.-Blakeley Formation of Weaver (1912) (late Oligocene and early Miocene),
Eugene Formation (early and middle Oligocene), Oregon; San Ramon Sandstone(early Miocene?), Wygal Sandstone Member (late Oligocene) of the Temblor Formation, California.

\section{Family PERIPLOMATIDAE \\ Genus Cochlodesma Couthouy}

Cochlodesma Couthouy, 1839, Boston Jour. Nat. Hist., v. 2, p. 170.

Type species.-By monotypy, Anatina leana Conrad, Holocene, Nova Scotia to North Carolina, United States.

\section{Cochlodesma bainbridgensis Clark \\ Plate 16, figures 4, 6-11}

Cochlodesma bainbridgensis Clark, 1925, California Univ. Pubs., Dept. Geol. Sci. Bull., v. 15, p. 86, pl. 13, figs. 3, 4. Tegland, 1933, California Univ. Pubs., Dept. Geol. Sci. Bull., v. 23, p. 112, pl. 6, figs. 3, 4. Weaver, 1942, Washington Univ. (Seattle) Pubs. Geology, v. 5, p. 117, pl. 25, fig. 1, pl. 29, fig. 2. Durham, 1944, California Univ. Pubs., Dept. Geol. Sci. Bull., v. 27, p. 141.

Cochlodesma bainbridgensis is small to moderate in size; it has a very thin fragile shell that is internally nacreous. The shell is sculptured with faint, concentric, slightly irregularly spaced undulations that do not resemble those present on Cyathodonta, a generic assignment considered for this species (Grant and Gale, 1931 , p. 255, footnote). On the hinge of a right valve, the condrophore is small, deep, subtriangular and directed posteriorly (pl. 16, fig. 9), closely matching that illustrated by Tegland (1933, pl. 6, fig. 3). The variation in outline of the four specimens figured (pl. 16, figs. 6, 8, 10, 11 ) is so great that it seems useless to try to use this as a specific criterion. Some of the variation is undoubtedly caused by deformation but some of it may be inherent. It has not been possible to separate the Cochlodesma in the Pittsburg Bluff Formation from C. bainbridgensis; possibly $C$. bainbridgensis is a species with a long time range. The preservation of the specimens in the collections is such that is has not been possible to determine if $C$. bainbridgensis is inequivalve with the right valve more convex.

Holotype.-SU 27.

Type locality.-SU loc. N.P. 103. In outcrops of shaly sandstones along beach between south side of entrance to Port Blakeley and Restoration Point, Wash. Blakeley Formation of Weaver (1912) (late Oligocene and early Miocene).

Paratype.-SU 28. Same locality as holotype.

A closely related form occurs in the Alsea Formation (early to late Oligocene), Oregon.

Localities.-USGS cf. 5392, 15278, 15519, 15583, 15588, M3872.

Occurrence elsewhere.-Poul Creek Formation (middle Oligocene to early Miocene), Yakataga District, Gulf of Alaska; Stepovak Formation of Burk (1965) (early and middle Oligocene), Coal Bay section, Alaska; 
Blakeley Formation of Weaver (1912) (late Oligocene and early Miocene), Washington.

\section{Family THRACIIDAE \\ Genus Thracia Blainville}

Thracia Blainville, 1824, Dictionnaire des sciences naturelles, v. 32, p. 347.

Type species.-By subsequent monotypy (Blainville, 1825, Manuel de malacologie et de conchyliologie, $\mathrm{p}$. 660 , removes his division B from Thracia, leaving but one species in the genus), Thracia corbuloides Blainville. Holocene, Mediterranean.

Sowerby (1823, The Mineral Conchology of Great Britain, v. 5, pt. 1, p. 20) under the discussion of $M y a$ mentions Thracia of Leach as a possible name to be applied to some forms he assigns to $M y a$. No particular species or figure is cited, and this reference to Thracia is considered a nomen nudum as listed by Vokes (1967, p. 339).

\section{Thracia (Thracia) condoni Dall}

Plate 16, figures 1,3

Thracia condoni Dall, 1909, U.S. Geol. Survey Prof. Paper 59, p. 135-136, pl. 19, fig. 5. Clark, 1918, California Univ., Dept. Geology Bull., v. 11, no. 2, p. 137, pl. 11, fig. 12; pl. 12, fig. 2. Tegland, 1933, California Univ. Pubs., Dept. Geol. Sci. Bull., v. 23, no. 3, p. 113, pl. 6, fig. 5. Weaver, 1942, Washington Univ. (Seattle) Pubs. Geology, v. 5, p. 119, pl. 25, fig. 10; pl. 29, fig. 15. Durham, 1944, California Univ. Pubs., Dept. Geol. Sci. Bull., v. 27, no. 5, p. 141, pl. 13, fig. 6. Hickman, 1969, Oregon Univ. Mus. Nat. Hist. Bull. 16, p. 72-73, pl. 9, figs. 10-14.

Thracia condoni is usually of small to moderate size. It is not common in the Pittsburg Bluff Formation. The specimen illustrated is the largest in the collections; it measures $46.7 \mathrm{~mm}$ long (broken) and $34.7 \mathrm{~mm}$ high. The shell is smooth except for bunched concentric lines. The beaks are centrally located. The posterior end is elongate and the dorsal margin is almost straight. The ligament nymph and groove can be seen on the preserved part of the hinge illustrated on plate 16, figure 3 . Parts of mineralized ligament are preserved on some specimens. Because of the thin shell, most of the specimens of $T$. condoni are crushed and distorted, and many are molds from which the shell has exfoliated. On the best preserved specimens, the right valve, noticeably larger than the left valve, overlaps the ventral edge. On a specimen with a left valve about $19.4 \mathrm{~mm}$ high, the right valve extends $1.7 \mathrm{~mm}$ beyond the ventral margin at the anterior end. On all specimens the beak on the right valve and the area along the dorsal edge of the anterior hinge have been abraded by the left valve.

\section{Holotype.-USNM 110460.}

Type locality._Smith's quarry, Eugene, Oreg. Eugene Formation (early and middle Oligocene).

$T$. condoni has a straighter posterior dorsal margin and is more elongate posteriorly than Thracia schencki Tegland (1933, p. 112-113, pl. 6, figs. 6-11). The umbos are lower on $T$. condoni, the shell less inflated, and the posterior end more elongate than on Thracia trapezoides Conrad (1849, p. 723, pl. 17, fig. 6a; Moore, 1963 , p. $84-85$, pl. 26, fig. 3; pl. 31, fig. 6).

Localities._USGS 15264, 15278, 15310, 15519, 15548, 15583, 15586, 15588.

Occurrences elsewhere.-Poul Creek Formation (Oligocene and Miocene), Yakataga District, Gulf of Alaska; Stepovak Formation of Burk (1965)(early and middle Oligocene), Alaska; Quimper Sandstone of Durham (1942) (early and middle Oligocene), Washington; Eugene Formation (early and middle Oligocene), Alsea Formation (early to late Oligocene), Oregon; San Lorenzo Formation (Eocene and Oligocene), California.

\section{Class CEPHALOPODA \\ Family NAUTILIDAE \\ Aturia angustata (Conrad) \\ Plate 15, figure 4}

Nautilus angustatus Conrad, 1849, U.S. Explor. Exped. Geology, v. 10, app. p. 728 , atlas, pl. 20 , figs. 5,6 .

Nautilites angustatus (Conrad). Conrad, 1858, Acad. Nat. Sci. Philadelphia Jour., v. 3 (new ser.), p. 335.

Aturia angustata (Conrad). Dall, in Diller, 1896, U.S. Geol. Survey 17th Ann. Rept., pt. 1, p. 459, 465, 467, 468. Dall, 1909, U.S. Geol. Survey Prof. Paper 59, p. 21. Schenck, 1931, California Univ. Pubs., Dept. Geol. Sci. Bull., v. 19, p. 457-462, pl. 69, figs. 1-3, pl. 70, figs. $1-5$, pl. 71, figs. $1,3-8$, pl. 72, figs. $1,2,5,6$, text figs. 4, 5, 7-9, 20-23, 30, 33. Weaver, 1942, Washington Univ. (Seattle) Pubs. Geology, v. 5, p. 551-552, pl. 102, figs. 1-7, 10. Miller, 1947, Geol. Soc. America Mem. 23, p. 85-88, pl. 48, figs. 5, 6, pl. 88, fig. 1, pl. 90, figs. 1-3, pl. 91, figs. 1-2, pl. 92, figs. 1, 2, 8, 9, pl. 93, figs. 3. 4. Moore, 1963, U.S. Geol. Survey Prof. Paper 419, p. 85-86, pl. 31, figs. 1, 5. Hickman, 1969, Oregon Univ. Mus. Nat. Hist. Bull. 16, p. 101-102, pl. 14, fig. 10.

Aturia ziczac (Sowerby). Conrad, 1865, Am. Jour. Conchology, v. 1, p. 150. Gabb, 1869, Paleontology of California, v. 2, p. 69. Dall and Harris, 1892, U.S. Geol. Survey Bull. 84, p. 223-224 (Not Nautilus ziczac Sowerby, 1812, Mineral Conch. Great Britain, v. 1, pl. 12, lowest fig.).

Aturia cf. ziczac (Sowerby). Reagan, 1908, Kansas Acad. Sci. Trans., v. 22, p. 171.

Aturia angustata has been described in detail by Schenck (1931, p. 457-462) and by Miller (1947, p. 8588).

Type species.-Larger figured syntype, USNM 3610 (Moore, 1963, pl. 31, fig. 1). This is the only specimen originally figured by Conrad (1849, pl. 20, fig. 5) that remains in the U.S. National Museum type collection.

Type locality.-Astoria, Oreg. Astoria Formation (Miocene).

The only specimen of $A$. angustata known from the Pittsburg Bluff Formation is the one figured on plate 15, fig. 4. It was collected and donated by Bruce Welton, from Portland State University, to whom I am indebted.

Locality. - Type locality for the Pittsburg Bluff Formation, near Pittsburg, Oregon. (Bruce Welton, written commun., Feb. 16, 1973). 
Occurrence elsewhere.-Early Oligocene to middle Miocene in the Coast Ranges of Washington, Oregon, and California. Lincoln Creek Formation (late Eocene to early Miocene) and Weaver's (1912) Blakeley Formation (late Oligocene and early Miocene), Washington; Eugene Formation (early and middle Oligocene) and possibly the Keasey Formation (late Eocene and early Oligocene), Oregon.

\section{U.S. GEOLOGICAL SURVEY FOSSIL LOCALITIES IN THE PITTSBURG BLUFF FORMATION, MIDDLE OLIGOCENE, NORTHWESTERN OREGON}

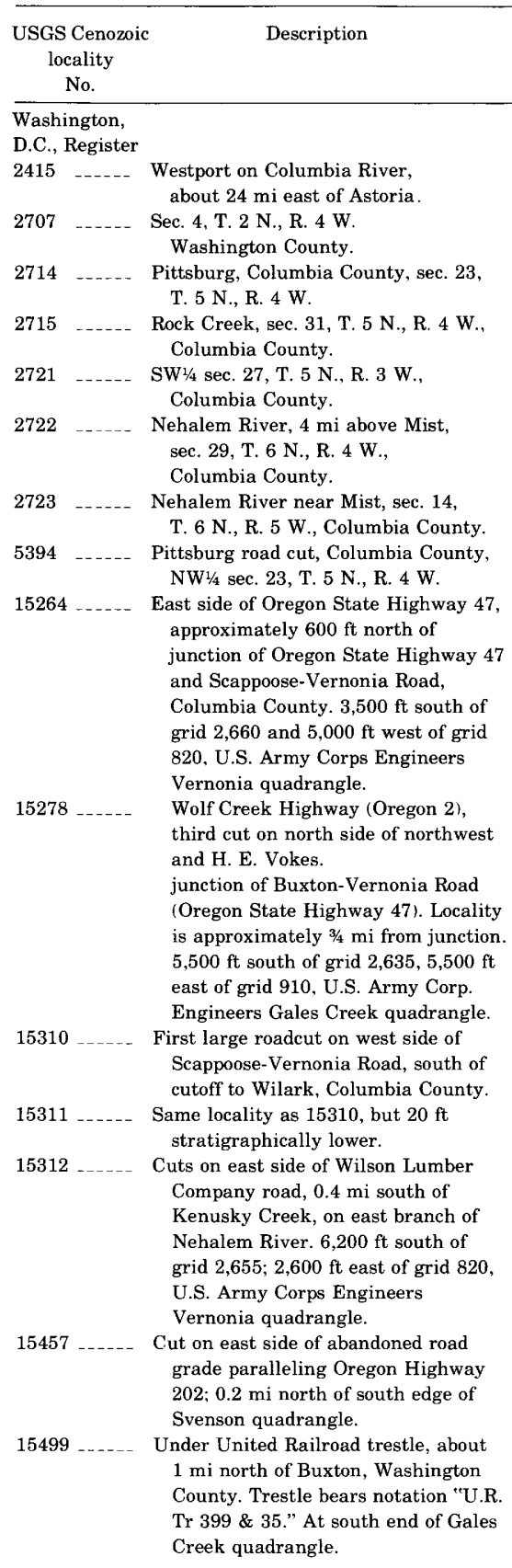

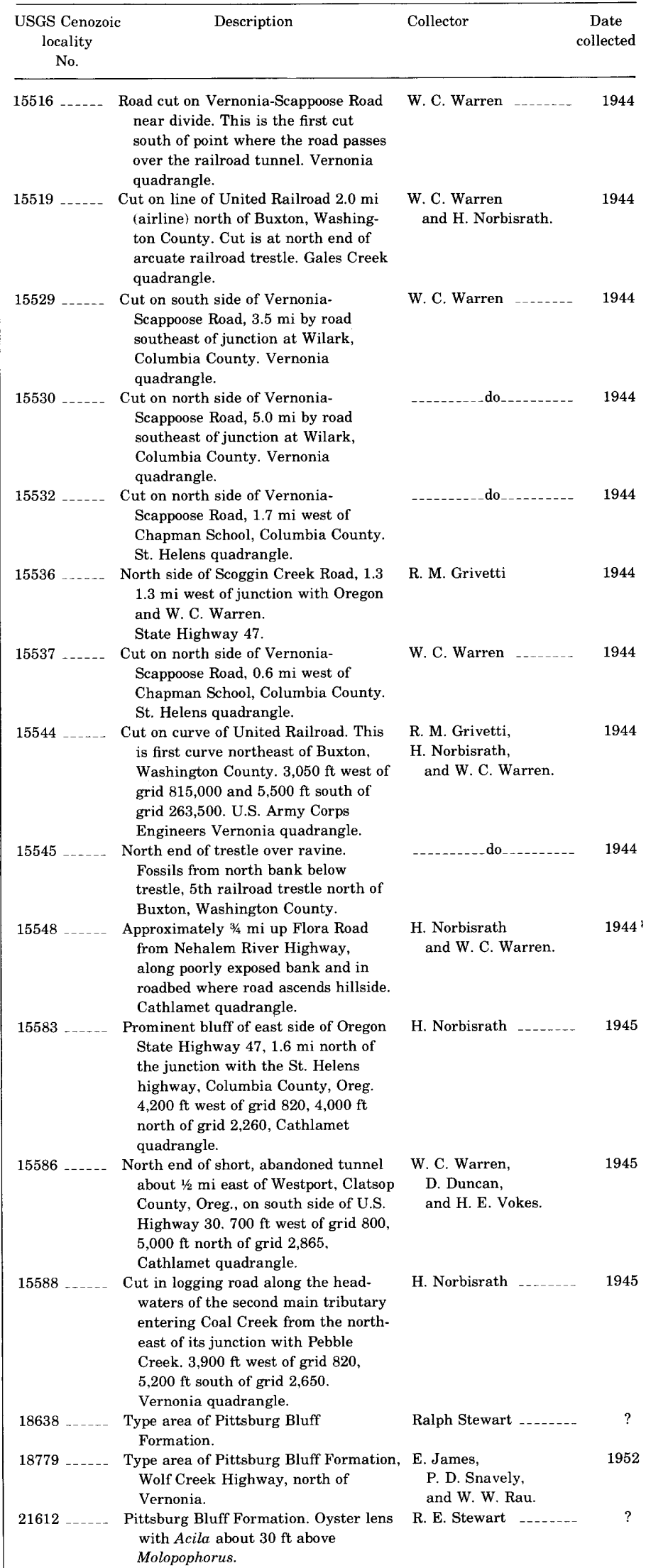
W. C. Warren 1944

W. C. Warren 1944 and $\mathrm{H}$. Norbisrath.

W. C. Warren 15537 Cut on north side of Vernonia Scappoose Road, $0.6 \mathrm{mi}$ west of Chapman School, Columbia County. St. Helens quadrangle.

15544 _._._ Cut on curve of United Railroad. This is first curve northeast of Buxton, Washington County. $3,050 \mathrm{ft}$ west of grid 815,000 and $5,500 \mathrm{ft}$ south of grid 263,500. U.S. Army Corps Engineers Vernonia quadrangle.

15545 _... North end of trestle over ravine. Fossils from north bank below trestle, 5th railroad trestle north of Buxton, Washington County.

15548 Approximately $3 / 4 \mathrm{mi}$ up Flora Road from Nehalem River Highway, along poorly exposed bank and in roadbed where road ascends hillside. Cathlamet quadrangle.

15583 _. _. Prominent bluff of east side of Oregon State Highway 47, $1.6 \mathrm{mi}$ north of the junction with the St. Helens highway, Columbia County, Oreg. $4,200 \mathrm{ft}$ west of grid $820,4,000 \mathrm{ft}$ north of grid 2,260, Cathlamet quadrangle.

15586 _. _. North end of short, abandoned tunnel about $1 / 2 \mathrm{mi}$ east of Westport, Clatsop County, Oreg., on south side of U.S. Highway $30.700 \mathrm{ft}$ west of grid 800 $5,000 \mathrm{ft}$ north of grid 2,865 Cathlamet quadrangle.

Cut in logging road along the headwaters of the second main tributary entering Coal Creek from the northeast of its junction with Pebble Creek. $3,900 \mathrm{ft}$ west of grid 820 $5,200 \mathrm{ft}$ south of grid 2,650 Vernonia quadrangle.

W. C. Warren,

D. Duncan,

and H. E. Vokes.

H. Norbisrath 1945

M. Grivetti,

Norbisrath,

and W. C. Warren.

H. Norbisrath and W. C. Warren.

1944 1945 Formatior

18779 _._._. Type area of Pittsburg Bluff Formation, E. James, Wolf Creek Highway, north of P. D. Snavely, Vernonia. and W. W. Rau

21612 Pittsburg Bluff Formation. Oyster lens with Acila about $30 \mathrm{ft}$ above Molopophorus.

1944

1944 


\begin{tabular}{|c|c|c|c|}
\hline $\begin{array}{c}\text { USGS Cenozoi } \\
\text { locality } \\
\text { No. }\end{array}$ & Description & & $\begin{array}{l}\text { Date } \\
\text { collected }\end{array}$ \\
\hline \multicolumn{4}{|c|}{$\begin{array}{l}\text { Menlo Park, } \\
\text { Calif. Register }\end{array}$} \\
\hline M3856 $\ldots$ & $\begin{array}{l}\text { Lat } 45^{\circ} 51.7^{\prime} \mathrm{N} \text {., long } 123^{\circ} 13.4^{\prime} \text {., along } \\
\text { private forest road } 300 \mathrm{~m} \text { northeast } \\
\text { of junction of Kenusky Creek and } \\
\text { East Fork of Nehalem River, } \\
\text { Columbia County. Middle of Pitts- } \\
\text { burg Bluff Formation. }\end{array}$ & E. J. Moore & 1968 \\
\hline M3857__..-- & $\begin{array}{l}\text { Lat } 45^{\circ} 51.2^{\prime} \mathrm{N} ., \text { long } 123^{\circ} 13.7^{\prime} \text { W., along } \\
\text { private forest road } 900 \mathrm{~m} \text { southeast } \\
\text { of junction of Kenusky Creek and } \\
\text { East Fork of Nehalem River. } \\
\text { Columbia County. Middle of } \\
\text { Pittsburg Bluff Formation. }\end{array}$ & do & 1968 \\
\hline M3858_.... & $\begin{array}{l}\text { Lat } 45^{\circ} 50.2^{\prime} \text { N., long } 123^{\circ} 02.7^{\prime} \text { W., along } \\
\text { private forest road near divide } \\
\text { between East Fork Nehalem River } \\
\text { and North Scappoose Creek, } 200 \mathrm{~m} \\
\text { north of bench mark } 1232 . \text { Columbia } \\
\text { County. Near top of Pittsburg Bluff } \\
\text { Formation. }\end{array}$ & do & 1968 \\
\hline M3860_--.-- & $\begin{array}{l}\text { Lat } 45^{\circ} 55.0^{\prime} \mathrm{N} ., \text { long } 123^{\circ} 08.0^{\prime} \mathrm{W} ., \\
\text { along private forest road } 750 \mathrm{~m} \\
\text { northeast of bench mark } 580, \text { which } \\
\text { is about } 1 \mathrm{~km} \text { north of Pittsburg on } \\
\text { Oregon State Highway } 47 \text {. Columbia } \\
\text { County. Base of Pittsburg Bluff } \\
\text { Formation. }\end{array}$ & _-_-____-_ do & 1968 \\
\hline M3866 & $\begin{array}{l}\text { Lat } 45^{\circ} 43.6^{\prime} \text { N., long } 123^{\circ} 11.1^{\prime} \text { W., } \\
\text { along Spokane, Portland, and Seattle } \\
\text { Railroad, } 200 \mathrm{~m} \text { north of Hares } \\
\text { Canyon. Washington County. Near } \\
\text { top of Pittsburg Bluff Formation. }\end{array}$ & -- & 1968 \\
\hline M3868 & $\begin{array}{l}\text { Lat } 45^{\circ} 43.4^{\prime} \text { N., long } 123^{\circ} 11.1^{\prime} \text { W.; } \\
\text { along Spokane, Portland, and Seattle } \\
\text { Railroad, } 200 \mathrm{~m} \text { south of Hares } \\
\text { Canyon. Washington County. Near } \\
\text { top of Pittsburg Bluff Formation. }\end{array}$ & - do & 1968 \\
\hline M3869 & $\begin{array}{l}\text { Lat } 45^{\circ} 43.3^{\prime} \text { N., long } 123^{\circ} 11.1^{\prime} \text { W., } \\
\text { along Spokane, Portland, and Seattle } \\
\text { Railroad, } 400 \mathrm{~m} \text { south of Hares } \\
\text { Canyon. Washington County. Near } \\
\text { top of Pittsburg Bluff Formation. }\end{array}$ & - & 1968 \\
\hline M3871_.... & $\begin{array}{l}\text { Lat } 45^{\circ} 48.6^{\prime} \mathrm{N} . \text {, long } 123^{\circ} 08.4^{\prime} \mathrm{W} ., \\
\text { along logging road on south side of } \\
\text { Coal Creek, } 350 \mathrm{~m} \text { east of first tribu- } \\
\text { tary to south. Columbia County. } \\
\text { Upper middle of Pittsburg Bluff } \\
\text { Formation. }\end{array}$ & - & 1968 \\
\hline M3872 & $\begin{array}{l}\text { Lat } 45^{\circ} 48.9^{\prime} \mathrm{N} ., \text { long } 123^{\circ} 08.0^{\prime} \mathrm{W} ., \\
\text { along logging road } 50 \mathrm{~m} \text { east of first } \\
\text { tributary to Coal Creek to north and } \\
1,000 \mathrm{~m} \text { northeast of junction of the } \\
\text { tributary with Coal Creek. Columbia } \\
\text { County. Upper middle of Pittsburg } \\
\text { Bluff Formation. }\end{array}$ & - & 1968 \\
\hline M3874 & $\begin{array}{l}\text { Lat } 45^{\circ} 51.5^{\prime} \mathrm{N} ., \text { long } 123^{\circ} 09.0^{\prime} \mathrm{W} ., \\
\text { along logging road on south side of } \\
\text { second valley north of Coon Creek, } \\
1.6 \mathrm{~km} \text { east of Oregon State High- } \\
\text { way } 47 \text { where it turns west to become } \\
\text { the main street of Vernonia. } \\
\text { Columbia County. Middle part of } \\
\text { Pittsburg Bluff Formation. }\end{array}$ & $-\mathrm{do}_{-}$ & 1968 \\
\hline M3877 & $\begin{array}{l}\text { Lat } 45^{\circ} 51.0^{\prime} \mathrm{N} ., \text { lang } 123^{\circ} 06.6^{\prime} \mathrm{W} \text {., } \\
\text { from roadcut along East Fork of } \\
\text { Nehalem River, } 650 \mathrm{~m} \text { northwest of } \\
\text { confluence of Jim George Creek, and } \\
100 \mathrm{~m} \text { south of main road. Columbia } \\
\text { County. Middle of Pittsburg Bluff } \\
\text { Formation. }\end{array}$ & - & 1968 \\
\hline M3878 & $\begin{array}{l}\text { Lat } 45^{\circ} 52.4^{\prime} \text { N., long } 123^{\circ} 07.5^{\prime} \mathrm{W} . \\
\text { from roadcut along main road that } \\
\text { follows East Fork of Nehalem River } \\
\text { directly west of confluence of Dog } \\
\text { Creek. Columbia County. Middle of } \\
\text { Pittsburg Bluff Formation. }\end{array}$ & $\mathrm{do}_{-}$ & 1968 \\
\hline
\end{tabular}

\section{REFERENCES CITED}

Abbott, R. T., 1954, American seashells: New York, Van Nostrand Co., Inc., 541 p., 40 pls.

Addicott, W. O., 1966, New Tertiary marine mollusks from Oregon and Washington: Jour. Paleontology, v. 40, no. 3, p. 635-646, pls. 76-78, 1 text fig.

1967, Zoogeographic evidence for Late Tertiary lateral slip on the San Andreas fault, California: U.S. Geol. Survey Prof. Paper 593-D, 12 p., 4 figs.

-1969 , Tertiary climatic change in the marginal northeastern Pacific Ocean: Science, v. 165, p. 583-586.

1970a, Latitudinal gradients in Tertiary molluscan faunas of the Pacific Coast: Palaeogeography, Palaeoclimatology, Palaeoecology, v. 8, p. 287-312, 7 figs.

1970b, Tertiary paleoclimatic trends in the San Joaquin Basin, California: U.S. Geol. Survey Prof. Paper 644-D, 19 p., 7 figs., 2 tables.

-1970c, Miocene gastropods and biostratigraphy of the Kern River area, California: U.S. Geol. Survey Prof. Paper 642, 174 p., $21 \mathrm{pls}$.

1971, Tertiary marine mollusks of Alaska: An annotated bibliography: U.S. Geol. Survey Bull. 1343, 30 p., 3 figs.

1972, Provincial middle and late Tertiary molluscan stages, Temblor Range, California: Pacific Sec. Soc. Econ. Paleontologists and Mineralogists, Pacific Coast Miocene Biostrat. Symposium, Bakersfield, Calif. 1972, Prog., p. 1-26.

1973, Oligocene molluscan biostratigraphy and paleontology of the lower part of the type Temblor Formation, California: U.S. Geol. Survey Prof. Paper 791, 48 p., 9 pls.

Adegoke, O. S., 1969, Stratigraphy and paleontology of the marine Neogene formations of the Coalinga region, California: California Univ. Pubs. Geol. Sci., v. 80, 241, p., 13 pls.

Allen, J. E., and Baldwin, E. M., 1944, Geology and coal resources of the Coos Bay quadrangle, Oregon: Oregon Dept. Geology and Mineral Industries Bull. 27, 157 p., 31 pls.

Anderson, F. M., and Martin, Bruce, 1914, Neocene record in the Temblor Basin, California, and Neocene deposits of the San Juan district, San Luis Obispo County: California Acad. Sci. Proc., ser. 4, v. 4, no. 3, p. 13-112, 8 pls., 1 map.

Arnold, Ralph, 1906, The Tertiary and Quaternary pectens of California: U.S. Geol. Survey Prof. Paper 47, 264 p., 53 pls. 1908, Descriptions of new Cretaceous and Tertiary fossils from the Santa Cruz Mountains, California: U.S. Natl. Mus. Proc., v. 34 , p. 345-390, pls. 31-37.

Arnold, Ralph, and Hannibal, Harold, 1913, The marine Tertiary stratigraphy of the north Pacific Coast of America: Am. Philos. Soc. Proc., v. 52, no. 212, p. 559-605.

Atwill, E. R., 1935, Oligocene Tumey Formation of California: Am. Assoc. Petroleum Geologists Bull., v. 19, no. 8, p. 1192-1204.

Berggren, W. A., 1972, A. Cenozoic time-scale-some implications for regional geology and paleobiogeography: Lethaia, v. 5, no. 2, p. 195-215, 9 figs.

Berry, S. S., 1954, On the supposed stenobathic habit of the California sea-mussel: California Dept. Fish and Game Bull., v. 40, p. 69-73.

Brabb, E. E., 1960, Geology of the Big Basin area, Santa Cruz Mountains, California [abs.]: Dissert. Abs., v. 21, no. 5, p. 1162 1163.

1964, Subdivision of San Lorenzo Formation (EoceneOligocene), west-central California: Am. Assoc. Petroleum Geologists Bull., v. 48, no. 5, p. 670-679, 2 figs.

Brown, R. D., Jr., and Gower, H. D., 1958, Twin River Formation (redefinition), northern Olympic Peninsula, Washington: Am. Assoc. Petroleum Geologists Bull., v. 42, no. 10, p. 2492-2512, 9 figs. 
Burch, J. Q., ed., 1944-46, Distributional list of the west American marine mollusks from San Diego, California, to the Polar Sea: Southern California Conchology Club Minutes nos. 33-63.

Burk, C. A., 1965, Geology of the Alaska Peninsula-Island arc and continental margin: Geol. Soc. America Mem. 99, Pts. 1-3, 250 p.

Clark, B. L., 1915, The occurrence of Oligocene in the Contra Costa Hills of middle California: California Univ. Dept. Geology Bull., v. 9, no. 2, p. 9-21.

1918, The San Lorenzo series of middle California: California Univ. Dept. Geology Bull., v. 11, no. 2, p. 45-235, pls. 3-24, 4 text figs.

- _ 1921, The marine Tertiary of the west coast of the United States: its sequence, paleogeography, and problems of correlation: Jour. Geology, v. 29, no. 7, p. 583-614, 12 figs.

1925, Pelecypoda from the marine Oligocene of Western North America: California Univ. Pubs., Dept. Geol. Sci. Bull., v. 15, no. 4 , p. $69-136$, pls. 8-22.

1929, Stratigraphy and faunal horizons of the coast ranges of California, with illustrations of index fossils of Tertiary horizons: Berkeley, Calif., privately published, 30 p., 50 pls.

-1932, Fauna of the Poul and Yakataga formations (upper Oligocene) of southern Alaska: Geol. Soc. America Bull., v. 43, p. 797-846, pls. 14-21, 1 fig.

1938, Fauna from the Markley Formation (upper Eocene) on Pleasant Creek, California: Geol. Soc. American Bull., v. 49, no. 5, p. $683-730$, pls. $1-4,1$ text fig.

Clark, B. L., and Anderson, C. A., 1938, Wheatland Formation and its relation to early Tertiary andesites in the Sierra Nevada: Geol. Soc. America Bull., v. 49, p. 931-956, 4 pls., 2 figs.

Clark, B. L., and Arnold, Ralph, 1918, Marine Oligocene of the West Coast of North America: Geol. Soc. America Bull., v. 29, p. 298308.

___ 1923, Fauna of the Sooke Formation, Vancouver Island, with description of a new coral by T. W. Vaughan: California Univ. Pubs., Dept. Geol. Sci. Bull., v. 14, no. 5, p. 123-234, pls. 15-42.

Clark, H. L., 1937, A new sea-urchin from the "Oligocene" of Oregon: San Diego Soc. Nat. Hist., v. 8, no. 28, p. 367-374.

Conrad, T. A., 1848, Fossil shells from Tertiary deposits on Columbia River, near Astoria: Am. Jour. Sci., ser. 2, v. 5, p. 432-433, 14 figs. -1849, Fossils from northwestern America, in Dana, J. D., U.S. Exploration Expedition, 1838-42, under Charles Wilkes, Geology, Volume 10: Philadelphia, Pa., app. p. 723-728; atlas, pls. 17-21.

Cushman, J. A., and Schenck, H. G., 1928, Two foraminiferal faunules from the Oregon Tertiary: California Univ. Pubs., Dept. Geol. Sci. Bull., v. 17, no. 9, p. 305-324, pls. 42-45.

Dall, W. H., 1890-1903, Contributions to the Tertiary fauna of Flori$\mathrm{da}$, with especial reference to the Miocene silex beds of Tampa and the Pliocene beds of the Caloosahatchie River: Wagner Free Inst. Sci. Trans., v. 3, pts. $1-6,1654$ p., 60 pls. 1890 , pt. 1, p. 1-200, pls. $1-12.1892$, pt. 2, p. 201-473, pls. 13-22. 1895 , pt. 3, p. 474-570. 1898 , pt. 4 , p. $571-947$, pls. $23-35$. 1900 , pt. 5, p. $948-1218$, pls. $37-47.1903$, pt. 6 , p. $1219-1654$, pls. $48-60$.

-1898, Table of North American Tertiary formations correlated with one another and with those of western Europe, with annotations: U.S. Geol. Survey 18th Ann. Rept., pt. 2, p. 327-348.

-1904 , Neozoic invertebrate fossils, a report on collections made by the expedition, in Volume 4, Geology and Paleontology, of Harriman Alaska Expedition: New York, Doubleday, Page and Co., p. 99-122, pls. 9, 10; reprinted by Smithsonian Inst., 1910. -1909 , Contributions to the Tertiary paleontology of the Pacific Coast I. The Miocene of Astoria and Coos Bay, Oregon: U.S. Geol. Survey Prof. Paper 59, 278 p., 28 pls., 14 figs.

Dall, W.H., and Harris, G. D., 1892, Correlation papers: Neocene: U.S. Geol. Survey Bull. 84, 349 p., 3 pls., 43 figs.
DeLise, K. C., 1967, Biostratigraphy of the San Emigdio Formation, Kern County, California: California Univ. Pubs. Geol. Sci., v. 68 , p. 1-67, 7 pls.

Denton, G. H., and Armstrong, R. L., 1969, Miocene Pliocene glaciations in southern Alaska: Am. Jour. Sci., v. 267, p. 1121-1142.

Detling, M. R., 1946, Foraminifera of the Coos Bay lower Tertiary, Coos County, Oregon: Jour. Paleontology, v. 20, no. 4, p. 348-361, pls. 46-51, 2 figs.

Dibblee, T. W., Jr., 1950, Geology of southwestern Santa Barbara County, California-Point Arguello, Lompoc, Point Conception, Los Olivos, and Gaviota quadrangles: California Dept. Nat. Resources Div. Mines Bull. 150, 95 p.

1966, Geology of the central Santa Ynez Mountains, Santa Barbara County, California: California Div. Mines and Geology Bull. 186, p. 1-91, 4 pls., 10 figs., 25 photos.

Dickerson, R. E., 1917, Climate and its influence upon the Oligocene faunas of the Pacific Coast, with descriptions of some new species from the Molopophorus lincolnensis Zone: California Acad. Sci. Proc., ser. 4, v. 7, no. 6, p. 157-192, pls. 27-31.

Diller, J. S., 1896, A geological reconnaissance in northwestern Oregon: U.S. Geol. Survey 17th Ann. Rept., pt. 1, p. 447-520.

Durham, J. W., 1937, Gastropods of the family Epitoniidae from Mesozoic and Cenozoic rocks of the west coast of North America, including one new species by F. Earl Turner and one by R. A. Bramkamp: Jour. Paleontology, v. 11, no. 6, p. 479-512, pls. $56-57$.

1942, Eocene and Oligocene coral faunas of Washington: Jour. Paleontology, v. 16, no. 1, p. 84-104.

1944, Megafaunal zones of the Oligocene of northwestern Washington: California Univ. Pubs., Dept. Geol. Sci. Bull., v. 27, no. 5, p. 101-211, pls. 13-18, 7 text figs., 1 map.

1952, Early Tertiary marine faunas and continental drift: Am. Jour. Sci., v. 250, p. 321-343.

1954, The marine Cenozoic of southern California: California Div. Mines Bull. 170, ch. 3, p. 23-31.

Eames, F. R., Banner, F. T., Blow, W. H., Clarke, W., and Cox, L. R., 1962, Fundamentals of mid-Tertiary stratigraphical correlation: Cambridge, England, Cambridge Univ. Press, 163 p.

Effinger, W. L., 1938, The Gries Ranch fauna (Oligocene) of western Washington: Jour. Paleontology, v. 12 , no. 4, p. 355-390, pls. $45-47,3$ text figs.

Etherington, T. J., 1931, Stratigraphy and fauna of the Astoria Miocene of southwest Washington: California Univ. Pubs., Dept. Geol. Sci. Bull., v. 20, no. 5, p. 31-142, 14 pls., 1 map.

Eyerdam, W. J., 1960, Mollusks and brachiopods from Afognak and Sitkalidak Islands, Kodiak Group, Alaska: Nautilus, v. 74, no. 2, p. 41-46; v. 74, no. 3, p. 91-95.

Fairchild, W. W., Wesendunk, P. R., and Weaver, D. W., 1969, Eocene and Oligocene Foraminifera from the Santa Cruz Mountains, California: California Univ. Pubs. Geol. Sci., v. 81, 93 p., 25 pls.

Fischer, A. G., and others, 1971, Time stratigraphic framework: California Univ., Scripps Inst. Oceanography, Deep Sea Drilling Project Initial Repts., v. 6, p. 1309-1317.

Fitch, J. E., 1953, Common marine bivalves of California: California Dept. Fish and Game Fish Bull. 90, 102 p., 63 figs.

Forrest, L. C., 1943, Sequence of Oligocene formations of California: California Div. Mines Bull. 118, p. 199-200, pl. 3.

Gabb, W. M., 1864, Description of the Cretaceous fossils: Paleontology of California, v. 1, sec. 4, p. 55-243, pls. 9-32.

-1866 , Tertiary invertebrate fossils: Paleontology of California, v. 2 , sec. 1 , pt. 1 , p. 1-38.

-1869 , Cretaceous and Tertiary fossils of California: Paleontology of California, v. 2, p. 1-299.

Grant, U. S., 4th, and Gale, H. R., 1931, Catalogue of the marine Pliocene and Pleistocene Mollusca of California and adjacent 
regions: San Diego Soc. Nat. Hist. Mem., v. 1, 1036 p., 32 pls., 15 figs., 3 tables.

Hanna, G. D., and Hertlein, L. G., 1943, Characteristic fossils of California: California Div. Mines Bull., v. 118, p. 165-182, figs. $60-67$.

Hedgpeth, Joel, and Hinton, Sam, 1961, Common seashore life of southern California in Naturegraph Ocean Guidebook, Volume 1,: Healdsburg, Calif., Naturegraph Co., 64 p., 250 figs.

Hertlein, L. G., and Crickmay, D. H., 1925, A summary of the nomenclature and stratigraphy of the marine Tertiary of Oregon and Washington: Am. Philos. Soc. Proc., v. 64, no. 2, p. 224-282.

Hertlein, L. G., and Grant, U. S., 4th, 1972, The geology and paleontology of the marine Pliocene of San Diego, California (Paleontology: Pelecypoda): San Diego Soc. Nat. Hist. Mem., pt. 2B, p. 143-409, 57 pls.

Hickman, C. J. S., 1969, The Oligocene marine molluscan fauna of the Eugene Formation in Oregon: Oregon Univ. Mus. Nat. Hist. Bull. $16,112 \mathrm{p} ., 14 \mathrm{pls}$.

1972, Review of the bathyal gastropod genus Phanerolepida (Homalopomatinae) and description of a new species from the Oregon Oligocene: Veliger, v. 15, no. 2, p. 107-112, 16 figs.

Howe, H. V. W., 1922, The Miocene of Clatsop and Lincoln Counties, Oregon: Stanford Univ., Calif. doctorate thesis, 186 p., 14 pls., 1 map.

Javidpour, Mahdokht, 1973, Some records on West American Cenozoic gastropods of the genus Aforia: Veliger, v. 15, no. 3, p. 196-205, 1. pl., 2 figs.

Jeletzky, J. A., 1973, Age and depositional environments of Tertiary rocks of Nootka Island, British Columbia (92-E); mollusks versus foraminifers: Canadian Jour. Earth Sci., v. 10, no. 3, p. 331-365, 3 pls. 2 figs.

Kamada, Yasuhiko, 1962, Tertiary marine Mollusca from the Joban coalfield, Japan: Palaeont. Soc. Japan Spec. Papers 8, 187 p., pls. $1-21$.

Kanno, Saburo, 1960, Palaeontology, Part II, in Arai, Juzo, and Kanno, Saburo, The Tertiary system of the Chichibu Basin, Saitama Prefecture, Central Japan: Tokyo, Ueno, Japan Soc. Promotion Sci. p. 123-396, pls. 31-51.

1971, Tertiary molluscan fauna from the Yakataga District and adjacent areas of southern Alaska: Palaont. Soc. Japan Spec. Papers 16, 153 p., 18 pls.

Keen, A. M., 1954, Five new species and a new subgenus in the pelecypod family Cardiidae: Am. Paleontology Bull., v. 35, p. 5-24, 1 pl., 9 text figs.

1958, Sea shells of tropical west America: Stanford, Calif., Stanford Univ. Press, 624 p., 10 pls., 1709 figs.

1963, Marine molluscan genera of western North America: an illustrated key: Stanford, Calif., Stanford Univ. Press, 126 p., 841 text figs.

1969, Mollusca G, Bivalvia, Pt. N, Volume 2, in Moore, R. C., Treatise on Invertebrate Paleontology: Geol. Soc. America and Kansas Univ.

1971, Sea shells of tropical west America; marine mollusks from Baja California to Peru: Stanford, Calif., Stanford Univ. Press, 1064 p., 22 pls., 3305 "figs."

Keen, A. M., and Bentson, Herdis, 1944, Check list of California Tertiary marine Mollusca: Geol. Soc. America Spec. Paper 56, 280 p., 4 figs.

Kleinpell, R. M., 1938, Miocene stratigraphy of California: Tulsa, Okla., Am. Assoc. Petroleum Geologists, 450 p., 14 figs.

Lowry, W. D., 1947, The extent of the Oligocene sea in northwestern Oregon: Geol. Soc. Oregon Country Geol. News Letter, v. 13, no. 1, p. 2-7.

McKeel, D. R., and Lipps, J. H., 1972, Calcareous plankton from the
Tertiary of Oregon: Palaeogeography, Palaeoclimatology, Palaeoecology, v. 12, no. 1/2, p. 75-93.

McLean, J. H., 1969, Marine shells of southern California: Los Angeles County Mus. Contr. Sci., ser. 24, Zoology no. 11, 104 p., 54 figs.

MacNeil, F. S., 1965, in Burk, C. A., Geology of the Alaska Peninsula-Island arc and continental margin (appendix C, p. 221-228): Geol. Soc. America Mem. 99, p. 1, 250 p.

1971, Selected mollusks from the Poul Creek and Yakataga Formations, Yakataga and Malaspina districts showing tentative identification and stratigraphic range in Miller, D. J., Geologic map of Yakataga district, Gulf of Alaska U.S. Geol. Survey Misc. Geol. Inv. Map I-610, scale 125,000, p. 3-5.

MacNeil, F. S., Wolfe, J. A., Miller, D. J., and Hopkins, D. M., 1961, Correlation of Tertiary formations of Alaska: Am. Assoc. Petroleum Geologists Bull., v. 45, no. 11, p. 1801-1809, 2 figs.

Meek, F. B., 1864, Check list of the invertebrate fossils of North America: Smithsonian Misc. Colln. 183, 32 p.

Merriam, C. W., 1941, Fossil turritellas from the Pacific coast region of North America: California Univ. Pubs., Dept. Geol. Sci. Bull., v. 26 , no. 1 , p. $1-214$, pls. $1-41,19$ text figs., 1 map.

Miller, A. K., 1947, Tertiary nautiloids of the Americas: Geol. Soc. America Mem. 23, 234 p., 100 pls.

Moody, C. L., 1916, Fauna of the Fernando of Los Angeles: California Univ. Dept. Geology Bull., v. 10, no. 4, p. 39-62, pls. 1, 2.

Moore, E. J., 1963, Miocene marine mollusks from the Astoria Formation in Oregon: U.S. Geol. Survey Prof. Paper 419, 109 p., 33 pls., 9 figs., 3 tables.

Moore, R. C., and Vokes, H. E., 1953, Lower Tertiary crinoids from northwestern Oregon: U.S. Geol. Survey Prof. Paper 233-E, p. 113-148, pls. 14-24.

Oakeshott, G. B., 1966, Geology of the California coast ranges: California Div. Mines and Geology Bull. 191, p. 36-40, fig. 3.

Oldroyd, I. S., 1924, Marine shells of Puget Sound and vicinity: Washington Univ. (Seattle), Puget Sound Biology Station Pub., v. 4, 272 p., 49 pls.

Packard, E. L., 1918, Molluscan fauna from San Francisco Bay: California Univ. Pub. Zoology, v. 14, no. 2, p. 199-452, pls. 14-60.

Palache, Charles, 1904, Geology about Chichagof Cove, Stepovak Bay, with notes on Popof and Unga Islands, in Volume 4, Geology and Paleontology of Harriman Alaska Expedition: New York, Doubleday, Page and Co., p. 69-88.

Parker, R. H., 1963, Zoogeography and ecology of some macroinvertebrates particularly mollusks, in the Gulf of California and the continental slope off Mexico: Dansk naturh. Foren. Vidensk. Medd., Bd. 126, 178 p., 14 pls.

Powell, A. W. B., 1966, The molluscan families Speightiidae and Turridae: an evaluation of the valid taxa, both Recent and fossil, with lists of characteristic species: Auckland Inst. Mus. Bull. 5, 184 p., 23 pls.

Rau, W. W., 1948, Foraminifera from the Porter Shale (Lincoln Formation), Grays Harbor County, Washington: Jour. Paleontology, v. 22, no. 2, p. 152-174, pls. 27-31, 1 text fig.

Rehder, H. A., 1955, The Genus Turcicula Dall: Malacol. Soc. London Proc., v. 31, p. 222-225, pl. 12.

Ruth, J. W., 1942, The molluscan genus Siphonalia of the Pacific Coast Tertiary: California Univ. Pubs., Dept. Geol. Sci. Bull., v. 26 , p. $287-306$, pls. $47-48$.

Schenck, H. G., 1927, Marine Oligocene of Oregon: California Univ. Pubs., Dept. Geol. Sci. Bull., v. 16, no. 12, p. 449-460.

1928, Stratigraphic relations of western Oregon Oligocene formations: California Univ. Pubs., Dept. Geol. Sci. Bull., v. 18, no. 1, p. 1-50, 18 text figs.

1929, Pittsburg Bluff fauna of the Oregon Oligocene [abs.]: Geol. Soc. America Bull., v. 40, no. 1, p. 163-164. 
1931, Cephalopods of the genus Aturia from western North America: California Univ. Pubs. Dept. Geol. Sci. Bull., v. 19, no. 19 , p. $435-490$, pls. $66-78$.

1936, Nuculid bivalves of the genus Acila: Geol. Soc. America Spec. Papers 4, 149 p., 18 pls., 17 tables, 14 figs.

Schenck, H. G., and Kleinpell, R. M., 1936, Refugian stage of the Pacific coast Tertiary: Am. Assoc. Petroleum Geologists Bull., v. 20 , no. 2, p. 215-225.

Shumard, B. F., 1858, Descriptions of new fossils from the Tertiary formations of Oregon and Washington Territories and the Cretaceous of Vancouver's Island, collected by Dr. Jno. Evans, U.S. Geologist, under instructions from the Department of the Interior: Acad. Sci. St. Louis Trans., v. 1, no. 2, p. 120-125. (Reprinted in Dall, 1909, p. 186-188.)

Slodkewitsch, V. S., 1967, Tretichnye Acila Sakhalina: Moscow, Nauka, 77 p.

Smith, A. G., and Gordon, Mackenzie, Jr., 1948, The marine mollusks and brachiopods of Monterey Bay, California, and vicinity: California Acad. Sci. Proc., ser. 4, v. 26, no. 8, p. 147-245, pls. 3, 4, 4 text figs.

Smith, J. P., 1919, Climatic relations of the Tertiary and Quaternary faunas of the California region: California Acad. Sci. Proc., v. 9, p. 123-173, $1 \mathrm{pl}$.

Snavely, P. D., Jr., MacLeod, N. S., and Rau, W. W., 1969, Geology of the Newport area, Oregon: Ore Bin, v. 31, no. 2, p. 25-48.

Snavely, P. D., Jr., MacLeod, N. S., and Wagner, H. C., 1972a, Preliminary bedrock geologic map of the Cape Foulweather and Euchre Mountain quadrangles, Oregon: U.S. Geol. Survey openfile Map.

$-1972 \mathrm{~b}$, Preliminary bedrock geologic map of the Yaquina and Toledo quadrangles, Oregon: U.S. Geol. Survey open-file map.

1972c, Preliminary bedrock geologic map of the Waldport and Tidewater quadrangles, Oregon: U.S. Geol. Survey open-file map.

Snavely, P. D., Jr., MacLeod, N. S., Rau, W. W., Addicott, W. O., Pearl, J. E., and Quinterno, P. J., 1975, Alsea Formation-an Oligocene marine sedimentary sequence in the Oregon Coast Range: U.S. Geol. Survey Bull. 1395-F, 21 p.

Snavely, P. D., Jr., and Wagner, H. C., 1963, Tertiary geologic history of western Oregon and Washington: Washington Div. Mines and Geology Rept. Inv. 22, 25 p., 23 figs.

1964, Geologic sketch of northwestern Oregon: U.S. Geol. Survey Bull. 1181-M, p. M1-M17.

Stauffer, P. H., 1967, Grain-flow deposits and their implications, Santa Ynez Mountains, California: Jour. Sed. Petrology, v. 37, p. 487-508.

Stewart, R. B., 1926, Gabb's California fossil type gastropods: Acad. Nat. Sci. Philadelphia Proc., v. 78, p. 287-447,, pls. 20-32, 5 text figs. [1927].

1930, Gabb's California Cretaceous and Tertiary type lamellibranchs: Acad. Nat. Sci. Philadelphia Spec. Pub. 3, 314 p., 17 pls., 5 text figs.

Stewart, R. E., 1956, Stratigraphic implications of some Cenozoic Foraminifera from western Oregon: Ore Bin, v. 18, no. 7, p. 57-63, 1 fig.

Tegland, N. M., 1933, The fauna of the type Blakeley, upper Oligocene of Washington: California Univ. Pubs., Dept. Geol. Sci. Bull., v. 23 , no. 3, p. 81-174, pls. 2-15, 2 maps.

Thorson, Gunnar, 1957, Bottom communities (sublittoral or shallow shelf), in Hedgpeth, J. W., Treatise on marine ecology and paleoecology, v. 1, Ecology: Geol. Soc. America Mem. 67, p. 461534, 20 figs.

Trumbull, E. J., 1958, Shumard's type specimens of Tertiary mollusks from Oregon and other types at Washington University, St. Louis: Jour. Paleontology, v. 32, no. 5, p. 893-906, pls. 115-117.
Turner, F. E., 1938, Stratigraphy and Mollusca of the Eocene of western Oregon: Geol. Soc. America Spec. Paper 10, p. 1-130.

Van Winkle, K. E., 1918, Paleontology of the Oligocene of the Chehalis Valley, Washington: Washington Univ. (Seattle) Pubs. Geology, v. 1, no. 2, p. 69-97, pls. 6-7.

Vokes, H. E., 1939, Molluscan faunas of the Domengine and Arroyo Hondo Formations of the California Eocene: New York Acad. Sci. Annals, v. 38, p. 1-246, pls. 1-22.

-1967, Genera of the Bivalvia: A systematic and bibliographic catalogue: Am. Paleontology Bull., v. 51, no. 232, 394 p.

Vokes, H. E., Norbisrath, Hans, and Snavely, P. D., Jr., 1949, Geology of the Newport-Waldport area, Lincoln County, Oregon: U.S. Geol. Survey Oil and Gas Inv. Prelim. Map 88, scale 1:62,500.

Vokes, H. E., and Snavely, P. D., Jr., 1948, The age relationships of the Eugene and Fisher Formations: Geol. Soc. Oregon News Letter, v. 14 , no. 5, p. 38-41.

Vokes, H. E., Snavely, P. D., Jr., and Myers, D. A., 1951, Geology of the southern and southwestern border areas of the Willamette Valley, Oregon: U.S. Geol. Survey Oil and Gas Inv. Map OM-110, Scale 1:62,500.

Wagner, C. M., and Schilling, K. H., 1923, The San Lorenzo group of the San Emigdio region, California: California Univ. Pubs., Dept. Geol. Sci. Bull., v. 14, no. 6, p. 235-276, pls. 43-50.

Warren, W. C., Grivetti, R. M., and Norbisrath, Hans, 1945, Geology of northwestern Oregon west of Willamette River and north of latitude $45^{\circ} 15^{\prime}$ : U.S. Geol. Survey Oil and Gas Inv. Prelim. Map 42 , scale 1 in. to $2.3 \mathrm{mi}$, geol. map and text.

Warren, W. C., and Norbisrath, Hans, 1946, Stratigraphy of upper Nehalem River basin, northwestern Oregon: Am. Assoc. Petroleum Geologists Bull., v. 30, no. 2, p. 213-237, 2 text figs.

Washburne, C. W., 1914, Reconnaissance of the geology and oil prospects of northwestern Oregon: U.S. Geol. Survey Bull. 590, $111 \mathrm{p}$.

Watkins, Rodney, 1974, Paleobiology of an offshore molluscan Fauna from the California Oligocene: Paleogeography, Paleoclimatology, Paleoecology, v. 15, p. 245-266.

Weaver, C. E., 1912, A preliminary report on the Tertiary paleontology of western Washington: Washington Geol. Survey Bull. 15, p. $1-80$, pls. $1-15$.

_- 1916a, Tertiary faunal horizons of western Washington: Washington Univ. (Seattle) Pubs. Geology, v. 1, no. 1, p. 1-67, pls. $1-5$.

-1916b, The Tertiary formations of western Washington: Washington Geol. Survey Bull. 13, 327 p., 30 pls.

1916c, Eocene of lower Cowlitz River Valley, Washington: California Acad. Sci. Proc., ser. 4, v. 6, no. 1, p. 1-17, pl. 1. 1916d, The post-Eocene formations of western Washington: California Acad. Sci. Proc., ser. 4, v. 6, no. 2, p. 19-40.

-1916e, The Oligocene of Kitsap County, Washington: California Acad. Sci. Proc., ser. 4, v. 6, no. 3, p. 41-52.

-1937, Tertiary stratigraphy of western Washington and northwestern Oregon: Washington Univ. (Seattle) Pubs. Geology, v. 4, 266 p., 15 pls.

1942, Paleontology of the marine Tertiary formations of Oregon and Washington: Washington Univ. (Seattle) Pubs. Geology, v. 5, pts. I-III, 789 p., 104 pls. [1943].

1945, Stratigraphy and paleontology of the Tertiary formations at Coos Bay, Oregon: Washington Univ. (Seattle) Pubs. Geology, v. 6 , no. 2 , p. 31-62.

1953, Eocene and Paleocene deposits at Martinez, California: Washington Univ. (Seattle) Pubs. Geology, v. 7, p. 1-102.

Weaver, C. E., chm., and others, 1944, Correlation of the marine Cenozoic formations of western North America: Geol. Soc. America Bull., v. 55, no. 5, p. 569-598. 
Weaver, C. E., and Palmer, K. V. W., 1922, Fauna from the Eocene of Washington: Washington Univ. (Seattle) Pubs. Geology, v. 1, no. 3 , p. 1-56, pls. 8-12.

Weaver, D. W., and Kleinpell, R. M., 1963, Mollusca from the Turritella variata Zone, part II, in Oligocene biostratigraphy of the Santa Barbara embayment, California: California Univ. Pubs. Geol. Sci., v. 43, p. 81-161, pls. 18-38.

Welton, B. J., 1972, Fossil sharks in Oregon: Ore Bin, v. 34, no. 10, p. 161-169, pl. 1.

Wolfe, J. A., and Hopkins, D. M., 1967, Climatic changes recorded by Tertiary land floras in northwestern North America, in Tertiary correlations and climatic changes in the Pacific-Pacific Sci.
Cong., 11th, Tokyo, 1966, Symposium no. 25: Sendai, Japan, Sasaki Printing and Publishing Co., p. 67-76.

Woodring, W. P., 1957, Geology and paleontology of Canal Zone and adjoining parts of Panama; geology and description of Tertiary mollusks (gastropods: Trochidae to Turritellidae): U.S. Geol. Survey Prof. Paper 306-A, p. 1-145, pls. 1-23.

Zimmerman, John, Jr., 1944, Tumey Sandstone (Tertiary), Fresno County, California: Am. Assoc. Petroleum Geologists Bull., v. 28, p. 953-976, 3 figs.

Zullo, V. A., Kaar, R. F., Durham, J. W., and Allison, E. C., 1964, The echinoid genus Salenia in the eastern Pacific: Palaeontology (London), v. 7, pt. 2, p. 331-349. 


\section{INDEX}

\section{A \\ Page}

Abbreviations -..... 3 abrupta, Panopea acala, Leda (Acharax) willapaensis, Solemya _........... 20 Acila _.. 14, 18, 20, 21, 42, pl. 17

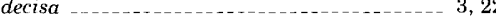
gettysburgensis zone .................... 3, 4 nehalemensis _. shumardi _.. $1,2,3,4,5,6,8,21,24,28,42,43$ biozone - _........ 2,9 Zone $\quad 1,2,5,6,8,9,23,24$ defined.......................... 2 (Acila) gettysburgensis

(Truncacila) $17,18,22,43$ nehalemensis minima shumardi

$2,14,15,16,19,21$ $23,24,26,28,42$, pl. 8

type locality

(Acila) decisa, Nucula gettysburgensis, Acila shumardi, Nucula (Ferminoscala) becki

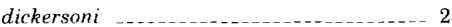

Acteocina chehalisensis _._. 40

Acteon

$17,18,20,40$ chehalisensis parvum _...... 28, 40, 41 sp..... $15,41, \mathrm{pl} .7$ Acteonidae - . acutilineata, Lucinoma Addicott, W. O., cited _._._. 23,24 addicotti, Aforia aduncanasa, Tellina Tellina (Eurytellina) _..- 14, 15, 16, 26, 50, pl. 11 Aforia

$17,18,19,20,37$

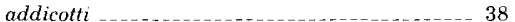
campbelli_.......... 11, 15, 26, 37, pl. 7 clallamensis _._._..._. 38 wardi _..._. 16,37 wardi 38

Agasoma acuminatum beds.... 4 columbiana -.... 3 columbianum Alaska Peninsula, Oligocene fossils _____ 8, 19 albensis, Nucula __ 42 albus, Polinices _... 32 aldrovandi, Panope Alegria Formation _... $8,24,25,28$ Calif _... 43,49 fauna 8,24 Algae, coralline 20 Alsea Bay, Oreg _. Alsea Formation _......... 10, 36, 44 mollusks _... $23,25,28$ Newport area Oreg $10,32,34,37,43,45,46,47$ $48,49,50,52,53,54$

Alvania

Anatina leana

Ancilla angustata, Aturia ______ 15, 16,54, pl. 15 angustatus, Nautilites

Nautilus _._._._._. 54

annulata, Lucinoma
[Italic page numbers indicate major references]

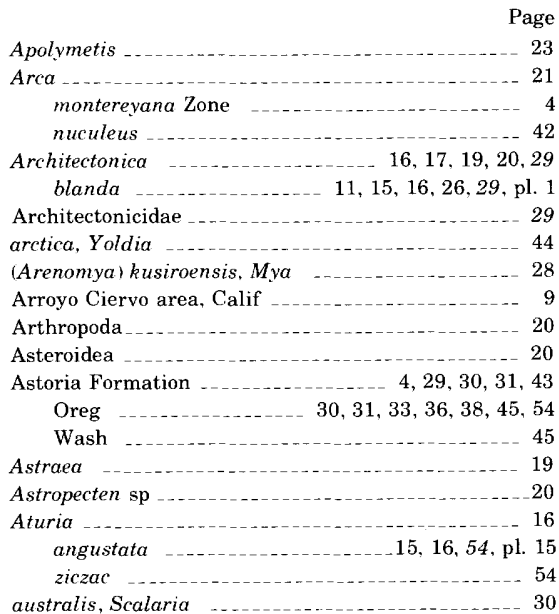

\section{B}

bainbridgensis, Cochlodesma $a_{-\ldots} 14,15,16,26,53, \mathrm{pl} .16$ Barbatia merriami Zone

Bastendorf [Bastendorff] Formation _......... 6, 24 [Bastendorff] Shale _ $5,6,7$

Bastendorff Shale _... 22, 23 foraminifera $\quad 8,22$ mollusks southwestern Oregon _..._........ 23 Bathybembix _._. 29 becki, Acrilla (Ferminoscala)._._._._._. 28

bentsonae, Gemmula 28

bigelowii, Braarudosphaera _._. 25

Biozone, definition - 2

biplicatus, Molopophorus ________._._. 35 quadranodosum. Molopophorus ______ 35

bisectus, Dictyococcites __._._._. 25 Blakeley beds _- 6 Blakeley Formation, Oreg Wash_..__ $10,30,32,36,39,43,44,45,46,47$,

$\begin{array}{rr}\text { Blakeley horizon } & 50,54,55 \\ & 4,5\end{array}$ Stage 7,9 blakelevensis, Turritella diversilineata _._._._._. 30 blanda, Architectonica ___ 11, 15, 16, 26, 29, pl. 1 borealis, Cardita

(Boreoscala) condoni, Epitonium 28 condoni eugenense, Epitonium _._______- 28 oregonensis, Epitonium _._______ 28 keaseyense, Epitonium _._. 31 Braarudosphaera bigelowii _..___. 25 Brisaster-_..._._. 19 maximus -_._._. 20 Brisingid sp -_. 20 Bruclarkia 16, 19,20,22,34 columbiana columbianum 24, 26, 28,34, pl. 3 vokesi brunnea, Natica Buccinidae - 35 Bukry, David, cited _._. 24, 25 Bulla lignaria _.... 41 Bullia (Molopophorus) striata _._. 35
C

Page

California, Oligocene fossils _._._._. 19 californica, Eosiphonalia _________ 33, 34 Callista cathcartensis _._._._._._._. 49 densa _._. 49 hornii _...__ 49 nimbosa _..._...................... 49 pittsburgensis _... $1,4,5,6,8,21,23,28,48,49$ pittsburgensis _....- $1,4,5,6,8,21,23,28,48,49$ (Macrocallista) (... 17 nimbosa pittsburgensis _--- $3,15,16,19,26,48$, pl. 12 (Callista) pittsburgensis, Meretrix _._._._. 48 Calyptraea diegoana sookensis sookensis
Calyptraeidae $\ldots$ campbelli. Aforia

Canada de Santa Anita, Calif ..... 23 Cancellaria _._. 20, 22 sp Cardiidae -

Cardiomya 20, 22

Cardita borealis _.

Carditamerinae _._.

Carditidae _...... 45

Cardium cooperii lorenzanum _._._. 47 lorenzanum _._. 47 semiasperum _._._._._._._._. 47 solidum _._._. 49

carinata, Spirotropis _____._._._. 39

Caryophyllia sp castrensis, Nucula _..._._._._._. 42 cathcartensis, Callista _..___._._._._._._. 49

Centroscymnus Cephalopod _. Cephalopoda _..._. 54

Chehalis River, Wash

chehalisensis, Acteocina _..._.
Acteon Acteon
Priscofusus Yoldia (Portlandella) _......... 20 Chiasmolithus oamaruensis ________._._. 25 chione, Venus Cibicides hodgei _._.

Clallam Formation

Clallam Stage _._.

clallamensis, Aforia wardi, Aforia ___._._. 16, 37

clarki, Pitar (Lamelliconcha) _._._._._._._._. 28 Solena __.___._. 52 Clatskanie, Oreg clausa, Cryptonatica _.... 31 Natica Clavella gravida _._._._. 34 Clavinae _... 39 (Cnestrium) oregona, Yoldia -._._. Coal
Coal Creek, Oreg Coaledo Formation, Oreg _._._._._. 31

Coast Ranges, California

Coccoliths planktonic _..._- 25 Coccolithus eopelagicus _-_._- 25 pelagicus _. _. _....... Cochlodesma _._._._._._._. 17, 20,53 
Cochlodesma-Continued.

bainbridgensis cocoaensis, Uvigerina

Coelenterata

colimana, Opalia

Collections, preparation

Columbia County, Oreg., stratigraphic section

$14,15,16,26,53$, pl. 16

Page clumbiana, Agasoma

Bruclarkia

Drillia

Lucina -

Lucinoma

Taranis Thesbia _._._._. 38

Turcicula _ _- 29

columbianum, Agasoma

Bruclarkia -..... 8, 28

Phacoides

condoni, Epitonium (Boreoscala)

eugenense, Epitonium (Boreoscala)

oregonensis, Epitonium (Boreoscala) _._._._. 28

Thracia _.______ 21, 28, 54

(Thracia) __ 14, 15, 16, 26, 54, pl. 16

Conger eels _.

Congridae - 17

conradi, Solen _._. 52

consimilis, Quercus _._.

Conus _- 20, 22

cooperii lorenzanum, Cardium _... 47

Yoldia _....... 44 (Kalavoldia)

Coos Bay, Oreg

Coral _. 21

Corbis _............... 22

corbuloides, Thracia _....

corrugatum, Perse

Cowlitz Formation, Wash ___ 31, 33

Crabs

crenata, Turbo

Crenella porterensis __._._._. 11, 15, 16, 19, 26, 45, pl. 12 washingtonensis Crenellinae

Crepidula pileum _._._._._._._11, 15, 16, 26,31, pl. 1 ungana (Spirocrypta) pileum Crinoid Beds, Keasey Formation

Crinoidea

Crinoids _._. 21, 22

$-20$

Crustacea _-_..._. 20

Crypta (Spirocrypta) pileum _-_ 31

Cryptonatica _ 17, 19,20.31 clausa _._._. 31 oregonensis pittsburgensis ____ $11,14,15,26,31, \mathrm{pl} .1$

Cvathodonta

Cyclicargolithus floridanus

Cyclocardia _. $17,18,20,45$ hannai hannibali _._. subtenta (Cyclocardia) hannibali ---- 8, 11, 15, 16,45, pl. 9 (Cyclocardia) hannibali,

Cyclocardia _...- 8, 11, 15, 16, 45, pl. 9 vlichnina ................ 22 turneri Cymric Shale Member Calif _... 34

Cypraea _-

D

Dall, W. H., cited

dalli, Molopophorus Pitar

(Pitar) -

$6,8,24,28,35$

$15,16,26,28,47$, pl. 12
Davilinae

Davilinae

$$
\text { Nucula... }
$$
(Acila) --

decussatus, Mytilus

Deer Island, Ores

Delectopecten

$$
\mathrm{sp} \text {, Callista }
$$

Dentaliidae

Dentalium

elephantinum

ergasticum _._._._._._._._._._. 41

laneensis _._. 9, 42 porterensis _._._._...-. 22

(Fissidentalium) -_...... 17, 18 laneensis _.... 14, 15, 16, 26, 28, 41 , pl. 7

Dentiscala

(Dentiscala), Opalia hertleini, Opalia $\ldots$

Diatoms _...... 20

dickersoni, Acrilla (Ferminoscala) _._._... 28 Suavodrillia _._._. 40

Surcula

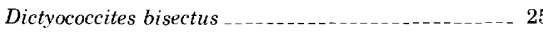

scrippsae

diegoana, Calyptraea

Diller, J. S., cited -... 23

Diplodonta

parilis -..._... 28,46

divaricata, Nucula

diversilineata blakeleyensis, Turritella

Drillia columbiana

kennicotti _.... 39

duplicata, Neverita

Durham, J. W., cited _._. 24

\section{$\mathrm{E}$}

Echinoderms _.

Echinoidea - _.

Echinoids _-__._ 8, 20,21

Echinophoria

rex Zone

Ecology

edulis, Mytilus

Eelgrass _-_

elephantinum, Dentalium _._. 41

Ennucula -

sp _.

Eocene, provincial correlation

Eocene-Oligocene boundary _._.

eocernua, Ocotea

eopelagicus, Coccolithus _..._-_._- 25

Eosiphonalia californica - 33,34 oregonensis _._._____ $3,11,15,16,26,33, \mathrm{pl} .4$ washingtonensis _..._._._._._. 33,34

(Eosiphonalia) oregonensis, Siphonalia _._._._. 33

Eosolen -_.___._._._._._. 16, 52

(Eosolen columbiana, Solena _-_..__._._. 52 eugenensis, Solena _- 14, 15, 16, 26, 28,52, pl. 13 Epitoniidae.

Epitonium -........ 20, 22 keaseyensis (Boreoscala) condoni condoni eugenense _._._._._. 28 oregonensis_._._._._._._._._._._. 28 keaseyense

ergasticum, Dentalium _...... 41 Ervilia oregonensis - 15, 16, 26, 50, pl. 16 Eugene, Oreg _._ 21, 25, 52 Eugene Formation $25,28,35,43,44$ age fauna
lithology Oreg - $3,10,32,33,34,41,42,43,44,45$ $46,47,48,49,50,51,52,53,54,55$ eugenense, Epitonium (Boreoscala) condoni _._._. 28
Page

eugenense-Continued.

Parvicardium

$-28$

eugenensis, Modiolus ___ 28

Solen - -

Solena -..._. 21,52 (Eosolen) --_-_._- 14, 15, 16, 26, 28, 52, pl, 13 Spisula _._..._. 28,50 eugenia, Tellina Eurytellina

(Eurytellina), Tellina _. 17, 18 aduncanasa, Tellina __ $14,15,16,26,50, \mathrm{pl} .11$ Exilia -_. 20, 22, 23 lincolnensis _...

\section{F}

Fasciolariidae 36

Fauna, Eugene Formation 23 Gries Ranch Formation _.___ 6, 21, 23 Holocene

Keasey Formation

Pittsburg Bluff Formation _...___ 2, 3, 11, 16, 17 , $19,20,23$

$19,20,22,23$

Stepof Bay, Alaska

Tunnel Point Sandstone _._._._._._. 22

Faunas, Oligocene Pacific coast _... 2,9

(Felania) usta, Mysia

Felaniella _..._. 17, 18, 20, 46

goodspeedi _..._. 46 griesensis _-_._._. 47 parilis _..-_. 47

serricata - _. 46

snavelyi 46,47

(Felaniella) snavelyi _... 14, 15, 16, 26, 46, pl. 10 (Felaniella) snavelyi, Felaniella _..__._ 14, 15, 16, 26, 46 , pl. 10

(Ferminoscala) becki, Acrilla dickersoni, Acrilla Ficus

modesta

Fimbria -

Fish _.

Fish scales - 20

Fisher Formation -

fishii, Molopophorus _- 28

Fissidentalium _-_...- 41

(Fissidentalium), Dentalium -__ 18 laneensis, Dentalium _........ 14, 15, 16, 26, 28, 41, pl. 7

Fissurella

Fissurella - 17

Flabellum _... 21 hertleini -...... 20

floridanus, Cyclicargolithus _..._........ 25

Foraminifera Bastendorff Shale _......... 22 planktonic _..._. 9, 17, 25 Refugian Stage - _. 6 stages _ upper Refugian Stage 6 zones

Formations, Oligocene, California 6

fornicata, Patella 31 Fossil localities, U.S. Geological Survey, Pittsburg Bluff Formation

Fossils, collection

Dall identifications

fish _... 17

fragments

locality numbers ...................... 2

Pittsburg Bluff Formation _._-_._._-_._- 7

plant leaves _... 8

preparation _._.

San Lorenzo Formation _......... 3

sea urchin

Fresno County, Calif

Fulgurofusus _.

sp
Fusinidae 
Fusinus (Priscofusus) stewarti Page Fusus geniculus G

gabbi, Molopophorus $1,2,3,5,11,14,15$, $16,23,24,26,35$, pl. 5 Galvin Station, Lewis County, Wash Gastropoda _..._...... 29 Gastropods _.._. 11, 14, 15, 16,17, 18, 19, 20,21, $22,23,26,28$

Gaviota Formation -....... 24 fauna

Gemmula _....... 20, 22 bentsonae _.......... 28 geniculus, Fusus _....... 36 gettysburgensis, Acila (Acila) _..._.___._... 43 gigantea. Venus gigantea. Venus
Globigerinids Glossaulax ...

(Glossaulax), Neverita

reclusiana, Nete thomsonae, Neverita Glycymeris -_... 21 glycimeris, Mya____ 52 goodspeedi, Felaneilla Taras _-_ 46 Gorgonid coral gravida, Clavella Grecco Ranch House Grecco Ranch House deposition ….... 21 equivalent

fauna

$6,21,23$

Oreg

Wash _.__ 6, $31,32,33,40,41,44,51,52$ Gries Ranch horizon griesensis, Felaniella _.... 47 Gyrineum 20,22

\section{$\mathrm{H}$}

Habitats, mollusks _....... 17, 18, 19 Haliotis haliotoidea. Helix hannai, Cyclocardia._._._._._._...... 45 hannibali, Cyclocardia _._.... 45 Cyclocardia (Cyclocardia) _- 8, 11, 15, 16, 45, pl. 9 Lucinoma

hanniballi, Nucula _....... 42

haydoni, Planulina

Helix $h$

Hemifusus washingtoniana _._._._._._._. 36

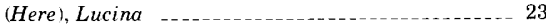

hertleini, Flabellum

Opalia (Dentiscala) _... 11, 15, 16, 26, 30, pl. 3 Suavodrillia _._._._._._._. 39,40

(Heteromacoma) vancouverensis, Macoma _______ 28

Hiatellidae ..... _........ 52

History of investigation ..........

hodgei, Cibicides

hornii, Callista

hyperborea, Yoldia

inquinata, Macoma Introduction

Isocrinus _.....

nehalemensis ..._. 20

oregonensis..._._.

Isthmolithus recurvus _._._______ 25

J

jamesae, Neverita _....... 33 Japan _..... 8 Jones Beach _._.

josephinia, Neverita

\section{K}

Page

Kalayoldia

(Kalayoldia), Yoldia

$--44$ oregona, Yoldia $14,15,16,26,28,44$, pl. 9 Keasey Formation $21,23,24,25$ age cocoliths deposition fauna mollusks 28,29 northwestern Oregon Oreg - _... 10,33,41, 45, 47, 55 Vernonia area _..._._._. $19,20,21,30$ volcanic ash _...

Keasey Shale _... 1,6 Keasey Stage keaseyensis, Epitonium! _.......... 20 Epitonium (Boreoscala) _._____ 31 Keenaea _-_ 47 (Keenaea), Nemocardium lorenzanum, Nemocardium_14, 15, 16, 26, 47, pl. 10 kennicotti, Drillia kincaidi, Spirotropis _.. 11, 14, 15, 26, 39, pl. 7 Turricula -_- 39 Turris

Kirker Formation, Calif ___._._. 43

Kirker Sandstone _..._. 8

Kirker Tuff

Kleinpell, R. M., cited quoted

Knefastia

Kreyenhagen Formation -....... 9

Kreyenhagen Shale

Calif

44,49

kusiroensis, Mya (Arenomya) _... 28

L

Lacia --_-_-_-_.-.-... 42 laevis, Pandora (Pandora) _.............. 28

(Lamelliconcha) clarki, Pitar _-__-_._-_._- 28 laneensis, Dentalium Dentalium (Fissidentalium) _._. 14, 15, 16, 26, 28,41, pl. 7

leana, Anatina -.... 53

Leda acala lincolnensis _....... 43 oregona _._....... 44 washingtonensis _._._. 43

Leionucula -._.... 42 (Leionucula), Nucula - 17, 18 nuculana, Nucula _..._-_._._._. 42 vokesi, Nucula _._._._. 14, 15, 16, 26, 42, pl. 8 lignaria, Bulla Lima

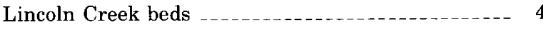
Lincoln Creek Formation Wash $\quad 8,10,24,28,29,30,31,32,33,34,35$ $36,38,39,40,41,43,44,45,47,48,49,53,55$ Lincoln Formation _....... 4, 35, 38 Lincoln horizon Lincoln [Lincoln Creek] Formation _- 3, 5, 6, 8, 23, 24 Lincoln Stage lincolnensis, Exilia 20,28 Leda
Molopophorus Natica _. Nuculana .............................. 4

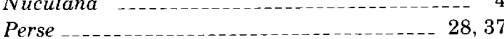
Perse
Polinices _-_- 28, 37 washingtonensis (Polinices) washingtonensis Solena _.......... 52 Tellina (Moerella) _..._- 28 Liracassis _..._- 16, 19, 20, 43 washingtonensis _._- 8, 14, 15, 16, 21, 26, 43, pl. 9 Long Island, N.Y. lorenzana, Solena $\quad \begin{array}{r}\text { Page } \\ -\end{array}$ lorenzanum, Cardium _............ 47 Cardium cooperii Nemocardium (Keenaea) -.... 14, 15, 16, 26, 47, pl. 10 Lorenzian Stage _............................. 9 Loxocardium - 21, 23 Lucina columbiana _... 21, 29 filosa (Here)

Lucinidae - _. Lucinoma acutilineata _._._._. 28, 46 annulata _._. 46 columbiana _____ 8,14, 15, 16, 26, 45, pl. 10 hannibali -..-.-.-.- 46

M

Macoma _._. 20, 22, 23 inquinata _-_. (Heteromacoma) vancouverensis Macrocallista -_. pittsburgensis . community ....................... 9

(Macrocallista), Callista _._._._. 17 nimbosa, Callista pittsburgensis, Callista 48, pl. 12

Macrouridae -

Mactra ovalis _._- 49 pittsburgensis _-_._._._. 6 solida _._.

Mactracea -...- 50

Mactridae -

Mactromeris --..... 49

(Mactromeris), Spisula _._.___. 17, 18, 50 pittsburgensis, Spisula _.______ 14, 15, 16, 26 49 , pl. 14 veneriformis, Spisula _._____._._._11, 15, 16, 26,

Malletia $50, \mathrm{pl} .14$ mamillaria, Natica Margaritan Stage

Marrowstone Shale, Wash _..._._._._... 34, 48 Martesia -.... 22 sp maximus, Brisaster _....... 20

Megafaunal zones, Tertiary _._._.......... 24

Meretrix (Callista) pittsburgensis _.__________ 48 merriama. Nuculana -_-_-_ 22 Mesodesmatidae minima, Acila (Truncacila) nehalemensis _._._._. 28 Minormalletia -_._.- 22 sp Miocene, provincial correlation _.. 2, 5, 11, 20, 21 Mist, Oreg -
Mitra modesta, Ficus _._-_._- 28 Modiolus _._._._. 22 eugenensis - _. (Moerella) lincolnensis, Tellina ___________ 28 Mollusca -_-_-_._.... 29

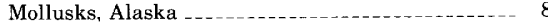
Alsea Formation _............ 23 Asiatic origin .... 8 Bastendorff Shale _..._. 22 Calif 6,8 faunal zones _........ 14 fragments habitats infaunal community _................... 17 Keasey Formation Lincoln Stage Newport area Oreg - Pacific Coast Pacific Coast $20,22,25,28$

distribution post-late Eocene 


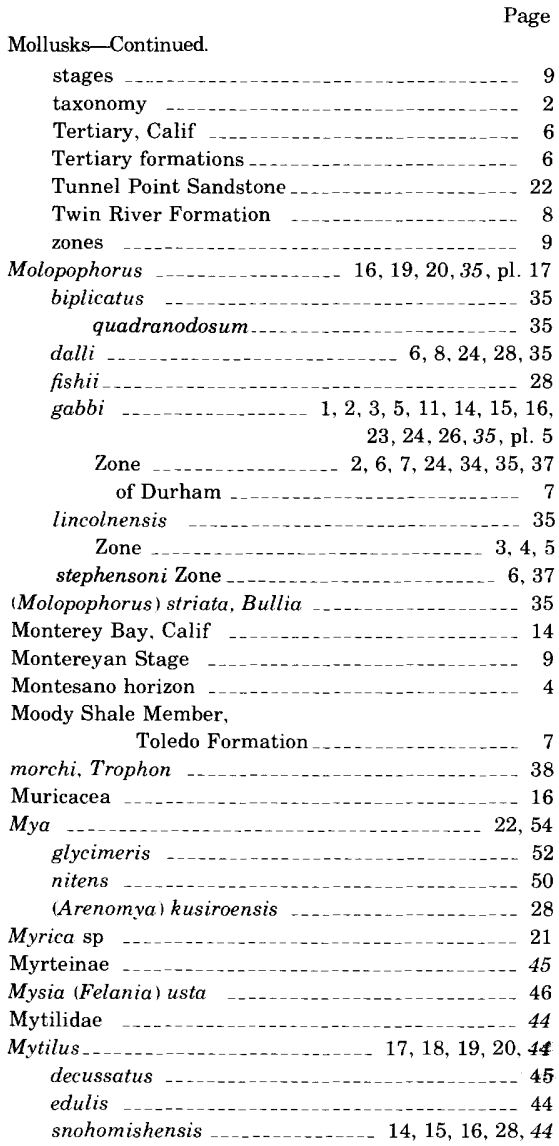

$\mathrm{N}$

Natica brunnea

clausa

lincolnensis _._._._._._._._. 32

mamillaria _._._- 32

tectula

washingtonensis _....... 32

weaveri -._-_- 31

(Natica) sp -...- 28

(Natica) sp., Natica -_..._. 28

Naticidae

Naticids.

Naticinae -

Nautilidae _.

Nautilites angustatus _._._._._. 54

Nautilus angustatus _._._._. 54

Nehalem River, Oreg _______ 2, 3, 5, 11, 37, 50, 51

Nehalem River Highway, near Pittsburg, Oreg Acila (Truncacila) Isocrinus _... minima, Acila (Truncacila) _..._..._... 28

Neilo oregona

Nekewis - 20,22

Nemocardium _ 22,47 lorenzanum _. $8,19,21,47$ samarangae _-_._._._._._. 47 (Keenaea) _._. 17, 18 lorenzanum $\quad 14,15,16,26,47$, pl. 10 Neptunea Neptuneidae Nestucca Formation _._.

Neverita _ $16,18,20,32$ duplicata....... 19 jamesae _._......-_._. 33

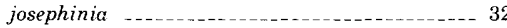
reclusiana thomsonae - 8, 9, 21, 28, 32
Neverita-Continued.

(Glossaulax)

reclusiana

17,18

Newport, Oreg

nimbosa, Callista

Callista (Macrocallista)
Venus

nitens, $M y a_{\ldots} \ldots$

Norbisrath, Hans, quoted _.

Notorhynchus _..._..._._._._._._. 17

Nucula

albensis _...

castrensis 42

decisa

divaricata - _.

hanniballi _._._._._._. 42

vokesi 42

Acila) decisa__._____ 42 shumardi -.._-_.-_- 42

Leionucula) _. 17, 18 nuculana
vokesi Nuculana_-_._._. 16, 22

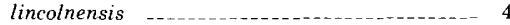

merriama _-_... 22

oregona

washingtonensis _....._._._._._._._. 9, 20,28,43 community _... 9

nuculana. Nucula (Leionucula) ............... 42

Nuculanidae -... 43

nuculeus, Arca _.... 42

Nuculidae

Nye Shale

$\mathrm{O}$

oamaruensis, Chiasmolithus _._____._. 25 obliquum, Sinum _. 11, 15, 16, 19, 28, 33, pl. 1 obliquus, Solen

Ocotea eocernua

Odontaspis .

Odostomia $16,17,20,40$ winlockiana _._._._._. $11,15,16,26,40, \mathrm{pl} .3$ (Odostomia) winlockiana (Odostomia) winklockiana, Odostomia ______- 40 Olequahia _-.._- 20, 22 schench

28

Oligocene, climate

faunal horizons . .

formations

middle, U.S. Geological Survey fossil localities

provincial correlation

Oligocene faunas, Alaska _._._._._._. 8

Oreg summary

Pacific Coast _... 2

Oligocene sea $\quad 7,14,19,21$

Oligocene sediments, deposition $\ldots \ldots, 25$

Pacific Northwest

Oligocene-Miocene boundary _._._._- 24

Olivella

olympicensis, Perse _-_ 24, 37 quimpersensis, Perse Opalia _- 16,20,30

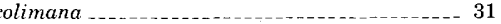
Dentiscala) _. 17, 18 hertleini - $11,15,16,26,30$, pl. 3

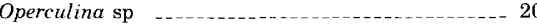

Opertochasma -22 turnerae - 28 turnera

Ophiuroide

Oregon, Oligocene faunas

Oligocene faunas, summary $\quad 23$

Oregon City, Oreg _..._. 44

oregona, Leda

Neilo --

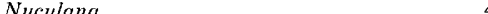

Yoldia
Page

oregona-Continued.

(Cnestrium)

$-4^{-} 44$

(Kalayoldia) $14,15,16,26,28$

44, pl. 9

(Portlandia)

31

oregonensis, Cryptonatica

Eosiphonalia ______ 3, 11, 15, 16, 26, 33, pl. 4

Epitonium (Boreoscala) condoni -....... 28

Ervilia _-_ 15, 16, 26, 50, pl. 16

Siphonalia 33

(Eosiphonalia)

Strepsidura _._. 33

Turritella

Ostrea 16,40

Otoliths _.....

ovalis, Mactra ____._. 49

Pachydesma -_..._._-_._. 22

packardi, Plectofrondicularia Spisula _-_ 22 Pandora -.. Spisula (Pandora) laevis _........ 28

(Pandora) laevis, Pandora _._. 28

Panope _..._-_._._. 52 aldrovandi _._._. ramonensis _._._._. 53 snohomishensis _._._._._. 52

Panopea _._._._._._._._._._. 19, 20,52 abrupta - ramonensis ____ $9,14,15,16,26,53, \mathrm{pl} .15$ snohomishensis_..._._-_ 14, 15, 16, 26,52, pl. 15 (Panopea) ramonensis ........... 28 (Panopea) ramonensis, Panopea _-_._...-_ 28

Parasyrinx _._. 39 parilis, Diplodonta Felaniella ___ 47

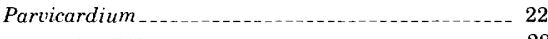
eugenense parvuum, Acteon Patella fornicata _-_ _._. 31 Pebble Creek ............. 6

Pecten 16, 22, 40 pelagicus, Coccolithus
Pelecypoda

Pelecypods________ $11,14,15,16,17,18,19,20$ $21,22,23,26,28$

Periplomatidae _.......... 53 Perse _..._. 16, 19, 20,36, pl. 17 corrugatum ......... 36 lincolnensis _... 28, 37 olympicensis quimpersensis _.._______ 6, 24, 37 pittsburgensis _........ 6, $611,14,15,16,24,26$, 36,37, pl. 6 vernoniensis _._._._._. 11, 14, 15, 26,37, pl. 6

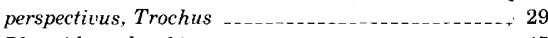
Phacoides columbianum _._._-_._-_._._._. 45 Phanerolepida____ 20,21 Pholas -_-_-_._. 22 pileum, Crepidula _-_ 11, 15, 16, 26, 31, pl. 1

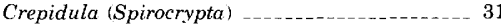
Crypta (Spirocrypta) _. 31 Pitar dalli (Lamelliconcha) clarki_________ 28 (Pitar) dalli _- 15, 16, 26, 28, 47, pl. 12 sp (Pitar) dalli, Pitar _._._ 15, 16, 26, 28, 47, pl. 12 sp., Pitar -...... 28 Pitaria dalli _._._._._._._. 47 Pitarinae Pittsburg, Oreg. Pittsburg Bluff, Oreg -....... 3 Pittsburg Bluff Formation _..... 1, 4, 5, 6, 10, 23, 24 41,50 age coal - 


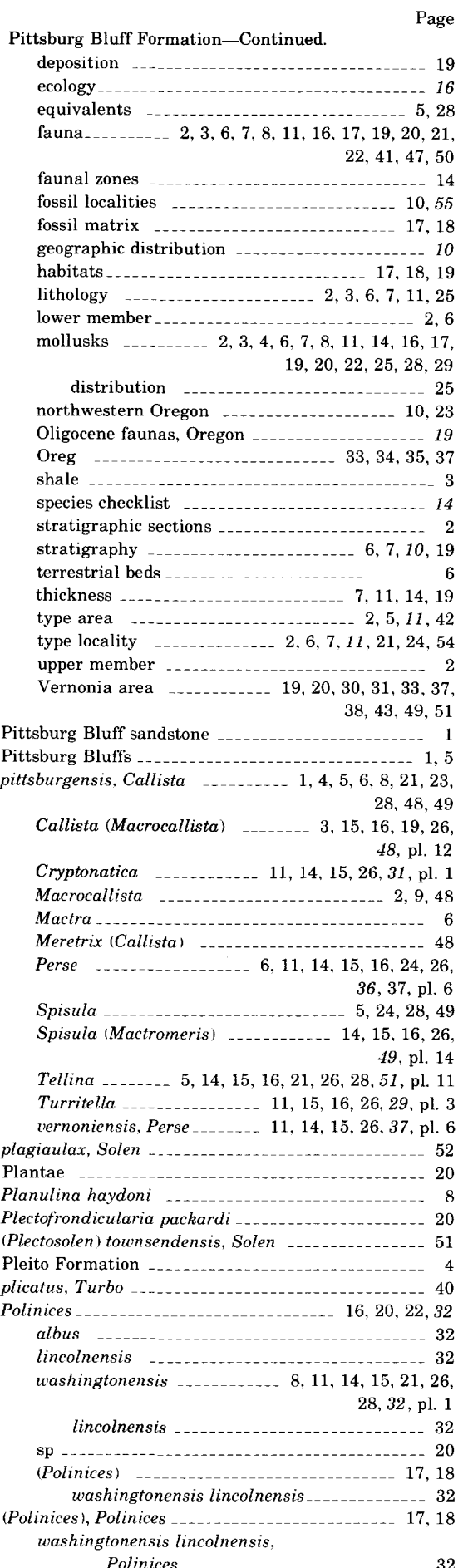

Polinices -32
Polinicinae Porter horizon Porter Shale _............ 7 porterensis, Crenella___ 11, 15, 16, 19, 26, 45, pl. 12 Dentalium _..._. 22 Turritella _.. 29,30 Porterius (Portlandella) chehalisensis, Yoldia _-__-_ 20 (Portlandia) oregona, Yoldia --_-_-_-_-_-_-_-_- 44 Poul Creek Formation Alaska _............ 8, 28, 34, 36, 43,44,45, 46 , $47,48,49,50,51,52,53,54$ mollusks 16. $19,20,36$
Priscofusus-Continued chehalisensis $11,15,16,26,36, \mathrm{pl} .3$ (Priscofusus) stewarti, Fusinus _._._._._..._._-_ 36 Pristiophorus _... Propeamussium -_- 21, 22 sp -

Protocardiinae

Pseudocardium .... sp Psychosyrinx _._. 39

Puncturella

punicea, Tellina

Purpose and scope

Pyramidellidae _._. 40

quadranodosum, Molopophorus biplicatus _...... 35 Quercus consimilis _. 21 Quimper Sandstone Wash
Wandstone $-1,34,35,41,44,50,51,52,54$ quimpersensis, Perse olympicensis ___ $6,24,37$

radiata, Tellina 50

Raja

ramonensis, Panope _._. 53 Panopea _.___._. 9, 14, 15, 16, 26, 53, pl. 15

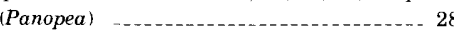

Rat tails

Ray teeth

reclusiana, Neverita

Neverita (Glossaulax)

recurvus, Isthmolithus ......

Refugian Stage _. definition _............... 24

foraminifers _.

Oreg ............. 23

type locality -_-_-

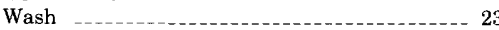

Reports dealing with Oligocene Formations and fossils, annotated chronology _... 3

Restoration Point, Wash Restoration Point horizon

Rices Mudstone Member, San Lorenzo Formation _-_-_-_ 8, 44, 47 rosaceus, Solen _._._._. 52

Salenia 20. 21 schencki samarangae Nemocardium San Emigdio Canyon, Calif San Emigdio Formation Calif mollusks ...

San Emigdio Mountains, Calif ....... 5, 9 San Lorenzo Formation Calif ___ 33, 36, 54 deposition _....... 9 foraminifera _members _._. mollusks.

Mount Diablo area

San Lorenzo Group -................. 4, 6 San Lorenzo Series _-_______ 4 San Ramon Formation ................ 5, 7, 8, 36 San Ramon horizon San Ramon Sandstone, Calif Santa Ynez Mountains, Santa Barbara County, Calif ….........- 23

Santa Ynez Range, Calif

Scalaria australis .-_._-_._._. 30 Scaphander $17,18,22,41$ stewarti__ $11,14,15,19,20,26,28$ washingtonensis $41, \mathrm{pl} .7$ Scaphandridae _.
Page

Scaphopod _._._._._._._ 14, 15, 16, 17, 18, 26, 28 Scaphopoda …-................ 41 Scappoose, Oreg - Scappoose Formation _._._..... 6, 7, 10, 11, 29 Schenck, H. G., cited _....... 24 quoted -........ 23

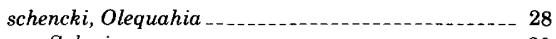
Salenia - 20 Thracia _- 54 scopulosum, Sinum _. scrippsae, Dictyococcites _____ 25

Seastars ___

Semele willamettensis _....... 28 semiasperum, Cardium _._._. 47 sericata, Taras ___ 46 serricata, Felaniella _..._._. Shark teeth

shumardi, Acila _..._....... 1, 2, 3, 4, 5, 6, 8, 21 , $24,28,42,43$ Acila (Truncacila) _..._- 2,14, 15, 16, 19,21, 23, $24,26,28,42$, pl. 8

Nucula (Acila) sicarius. Solen _ 28,51 Siltstone, Newport area, Oreg Siltstone of Alsea Sininae -

Sinum 16, 17, 18, 33 obliquum _._ 11, 15, 16, 19, 28, 33, pl. 1 scopulosum ......... 33

Siphonalia ___ 33 oregonensis _._. _..._... 33 (Eosiphonalia) oregonensis_-_-_-_-__._-_-_ 33 snavelyi, Felaniella -_... 46, 47 Felaniella (Felaniella)_-_ 14, 15, 16, 26, 46, pl. 10 snohomishensis, Mytilus __.____ 14, 15, 16, 28, 44 Panope -._- 52 Panopea _......... 14, 15, 16, 26, 52, pl. 15 Solemya _... 20,21, 22 (Acharax) willapaensis Solen conradi _-......... 52 eugenensis _...................... 52 obliquus _._. 52 plagiaulax -.... 52 rosaceus _sicarius _.__ 28,51 townsendensis _._._._._. $14,15,16,26,51$, pl. 13 vagina _._._._. 51 (Plectosolen) tounsendensis ______... 51

Soleng 20,5 clarki _._____ 52 eugenensis _._. 21, 52

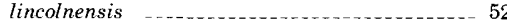
lorenzana (Eosolen) columbiana _._. 52 eugenensis _._._._._._._. $14,15,16,26,28$

$52, \mathrm{pl} .13$

Solenidae

solida, Mactra _-

solidissima, Spisula _._______ 19

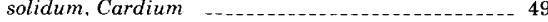

Sooke Formation -__ 4,5

Vancouver Island, B.C sookensis, Calyptraea _._............... 28

(Spirocrypta) pileum, Crepidula _....... 31

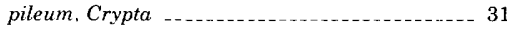
Spirotropis -_._._._._._17, 20,21, 22, 39 carinata _.............................. 39 kincaidi_______._._. 11, 14, 15, 26, 39, pl. washingtonensis _........................ 39 (Spirotropis) winlockensis _-___-_._._. 40 (Spirotropis) winlockensis, Spirotropis _._._. 40 Spisula _-_._._._18, 19, 20, 49 eugenensis _........................ 28, 50 packardi
pittsburgensis pittsburgensis _._._._._._._ $5,28,49$ solidissima .............................. 19 veneriformis
(Mactromeris) pittsburgensis _._._. $14,15,16,26,49, \mathrm{pl} .14$ 


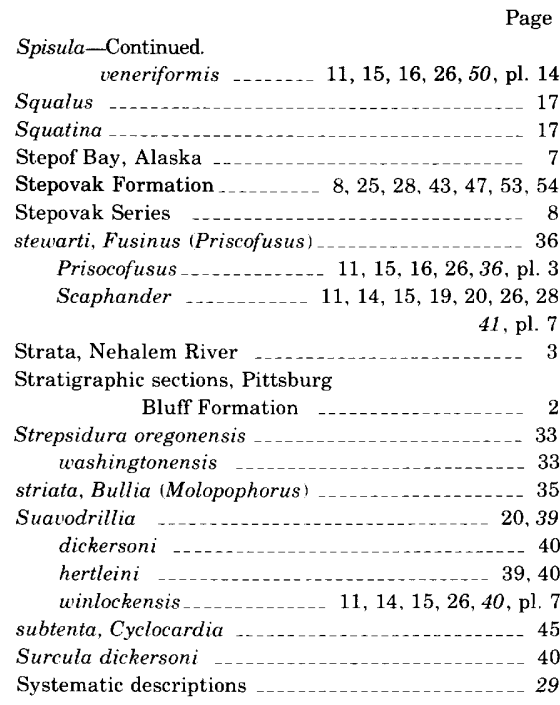

\section{$\mathrm{T}$}

Taranis

$17,18,20,38$ columbiana Taras goodspeedi sericata -... 46

Tectonatica _..._._........ 31

tectula, Natica _... 31

Tegula _........... 19

Tejon Formation Calif _._._. $31,33,35$

Tejon Pass, Calif .

Tejon Stage -...-...-. 5

Tellina $20,22,50$ aduncanasa _..._. $8,21,28,50$ eugenia __. pittsburgensis _..._..._._. $5,14,15,16,21,26$, 28,51, pl. 11 punicea _.... 50 radiata sp _-_ 20, 28

(Eurytellina) -............ 17, 18 aduncanasa -..... 14, 15, 16, 26, 50, pl. 11 (Moerella) lincolnensis __- 28

Tellinidae ........ 50

Tellininae

Temblor Formation Calif _

Temblor Range, Calif _........ 24

Temblorian Stage

tenuissima, Yoldia

$\begin{array}{ll}\text { terebra, Turbo } & 29 \\ \text { Thesbia columbiana } & \end{array}$

thomsonae, Neverita _ $\quad 8,9,21,28,32$ Neverita (Glossaulax) _.. 11, 14, 15, 26, 32, pl. 2 Thracia _._. 17, 18, 20, 22, 54 condoni $21,28,54$ corbuloides schencki trapezoides

(Thracia) condoni______ $14,15,16,26,54, \mathrm{pl} .16$ (Thracia) condoni, Thracia _- 14, 15, 16, 26, 54, pl. 16

Thraciidae -

Thuja sp

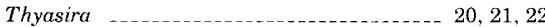

Tindaria __ 20.22

Toledo Formation . Moody Shale Member _..._._._._. 7 tornatilis, Voluta _.......... 40 tounsendensis, Solen ___ 14, 15, 16, 26, 51, pl. 13 Solen (Plectosolen) trapezoides, Thracia $\begin{array}{rr}\text { Page } \\ \text { Trochid, unidentified } & \text { 15, 29, pl. } 1\end{array}$ Trochidae -...- 29

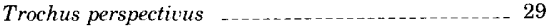
Trophon morchi 38 Truncacila Truncacila
(Truncacila), Acila nehalemensis, Acila _..._._._._. 20,21, 23, 28, 43 minima, Acila _... 28 shumardi. Acila $26,28,42$, pl. 8

tumens, Venus Tumey Formation
$\quad$ Calif Calif 6

Tumey Sandstone

Tunnel Point, Oreg

Tunnel Point beds 3

Tunnel Point Formation -...- 5, 6, 23, 24

Tunnel Point Sandstone $\ldots \ldots 1,5,6,22,44$ mollusks southwestern Oreg _-_._._ 23, 32, 34, 36, 39, 43 , $46,48,49,50,51,52$ plicatus terebra terebra
crcicula columbiana turnerae, Opertochasma _._._._._._. 28 turneri, Cylichnina _... 22, 28 Turricula kincaidi ___________ 39 Turriculinae _...

Turridae _ 37

Turrinae _

Turris kincaidi

Turritella _._._. 14, 16, 17, 18, 22, 29 diversilineata blakeleyensis $\quad 30$ olympicensis Zone oregonensis _ 29,30 pittsburgensis _._._._._._. 11, 15, 16, 26, 29, pl. 3 porterensis $\quad 29,30$ Zone $\ldots 3,4,6,34$ uvasana -...- 29, 30 variata lorenzana Zone _._._______ 24 Zone _._ 6, 23, 24 wheatlandensis Turritellidae -... 29

Twin River Formation _._._._._. 7, 10

Wash $\quad 10,45$ Two Bar Shale Member, San Lorenzo Formation $\mathrm{U}$

Umpquaia -.... ungana, Crepidula

Ungulinidae

Ushikubitoga Formation Japan

usta, Mvsia (Felania)

uvasana, Turritella

Uvigerina cocoaensis

vagina. Solen

Vancouver Island

Vaqueros Sandstone

Vaquerosian Stage

Veneridae ....

veneriformis, Spisula Spisula (Mactromeris)_-_- 11, 15, 16, 26, 50, pl. 14 Venus chione gigantea

nimbosa tumens

Vernonia, Oreg vernoniensis, Perse
vernoniensis_-Continued. pittsburgensis _-_- 11, 14, 15, 26,37, pl. 6 Vertebrata _............ 20 Vicksburg Group -----Vokes, H. E., cited _........ 2, 7, 14

kesi, Bruclarkia

Nucula..

Leionucula)

$14,15,16,26,42, \mathrm{pl}$

Voluta tornatilis

W

Wahkiakum horizon wardi, Aforia Aforia clallamensis .

Washington County, Oreg.

stratigraphic section _-_-_._. 2

washingtonensis, Crenella

Eosiphonalia ___ 33, 34

Leda

Litorhadia

$43, \mathrm{pl} .9$

Natica

Nuculana $9,20,28,43$

Polinices

Scaphander $32, \mathrm{pl}, 1$

Spirotropis

Strepsidura - .-...... 33

lincolnensis, Polinices _... 32

Polinices (Polinices)

washingtoniana, Hemifusus ..._. 36

Warren, W. C., quoted

Weaver, D. W., cited _._. 24

weaveri, Natica _._._._._._. 31

Welton, B. J., quoted _. 17

Wheatland Formation Calif ..... 28, 30, 32

wheatlandensis, Turritella

Whitneyella

Willamette Valley, Oreg

willamettensis, Semele _-___________ 28

willapaensis, Solemya (Acharax) _._._._._._. 20

Wilson's Bluff, Oreg

winlockensis, Spirotropis (Spirotropis) _- 40

Suavodrillia _____._. 11, 14, 15, 26, 40, pl. 7 winlockiana, Odostomia __._- 11, 15, 16, 26, 40, pl. 3 Odostomia (Odostomia) _......._._._._. 40

Worms, polychaete ...... 40 Wygal Sandstone Member -_-_-_-_-_-_-_-_ 9, 25, 28 Calif

$33,42,53$

\section{Y}

Yakataga Formation _........................ 5

Yaquina Formation Yoldia arctica -_._-_. 44 cooperii $\quad 44$ hyperborea oregona _-_._._- 44

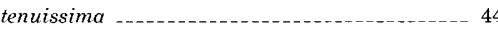
(Cnestrium) oregona _._._._._. (Kalayoldia) _-_ 17, 18 cooperi oregona $14,15,16,26,28$

$44, \mathrm{pl} .9$

(Portlandella) chehalisensis _._._._-_._-_. 20 (Portlandia) oregona strigata Zone

Zemorrian Stage ziczac, Aturia ................... 54 Zostera sp 


\section{PLATES 1-17}

[Contact photographs of the plates in this report are available, at cost, from U.S. Geological Survey Library, Federal Center, Denver, Colo. 80225.] 


\section{PLATE 1}

Figures 1-4. Architectonica blanda Dall, p. 29

1-3. Height (incomplete) $10.0 \mathrm{~mm}$, width (incomplete) $14.0 \mathrm{~mm}$. Locality USGS 15588. USNM 213945. 4. Height (incomplete) $8.5 \mathrm{~mm}$, width (incomplete) $14.0 \mathrm{~mm}$. Locality USGS 15588. USNM 213946.

5,8. Crepidula pileum (Gabb), p. 31

Height $4.5 \mathrm{~mm}$, width $8 \mathrm{~mm}$, length $18 \mathrm{~mm}$. Locality USGS 15310. USNM 213947.

6,7. Unidentified trochid?, p. 29

Height (incomplete) $18.3 \mathrm{~mm}$, width (incomplete) $24.8 \mathrm{~mm}$. Locality USGS 15312. USNM 213948.

9,12,13,15, 16, 18, 19, 23. Cryptonatica pittsburgensis, n. sp., p. 31

9. Height (incomplete) $19.0 \mathrm{~mm}$, width $12.1 \mathrm{~mm}$. Locality USGS 15310 . USNM 213949.

12. Height (incomplete) $17.8 \mathrm{~mm}$, width (incomplete) $16.9 \mathrm{~mm}$. Locality USGS 15588 . USNM 213950.

13. Height (incomplete) $16.0 \mathrm{~mm}$, width (incomplete) $14.0 \mathrm{~mm}$. Locality USGS $15310 \mathrm{~h}$. USNM 213951.

15, 23. Height (incomplete) $18.4 \mathrm{~mm}$, width $18.0 \mathrm{~mm}$. Locality USGS 15310. USNM 213952.

16. Height (incomplete) $18.4 \mathrm{~mm}$, width (incomplete) $18.6 \mathrm{~mm}$. Locality USGS 15588. USNM 213953.

18. Height (incomplete) $12.5 \mathrm{~mm}$, width $12.5 \mathrm{~mm}$. Locality USGS 2714 . USNM 213954.

19. Height $11.9 \mathrm{~mm}$, width (incomplete) $11.0 \mathrm{~mm}$. Locality USGS 15310 . USNM 213955.

10, 11. Sinum aff. S. obliquum (Gabb), p. 33

Height (incomplete) $8.7 \mathrm{~mm}$, width (incomplete) $9.2 \mathrm{~mm}$. Locality USGS 15264. USNM 213956.

14, 17, 20-22, 24. Polinices washingtonensis (Weaver), p. 32

14, 22. Height (incomplete) $24.2 \mathrm{~mm}$, width $23.7 \mathrm{~mm}$. Locality USGS 15310. USNM 213957.

17. Height(incomplete) $17.4 \mathrm{~mm}$, width (incomplete) $17.9 \mathrm{~mm}$. Locality USGS $15310 \mathrm{~h}$. USNM 213958.

20. Height (incomplete) $23.8 \mathrm{~mm}$, width (incomplete) $23.4 \mathrm{~mm}$. Locality USGS $15310 \mathrm{~h}$. USNM 213959

21. Height (incomplete) $29.8 \mathrm{~mm}$, width (incomplete) $27.6 \mathrm{~mm}$. Locality USGS 15588 . USNM 213960 .

24. Height (incomplete) $21.0 \mathrm{~mm}$, width $19.7 \mathrm{~mm}$. Locality USGS 15310h. USNM 213961. 

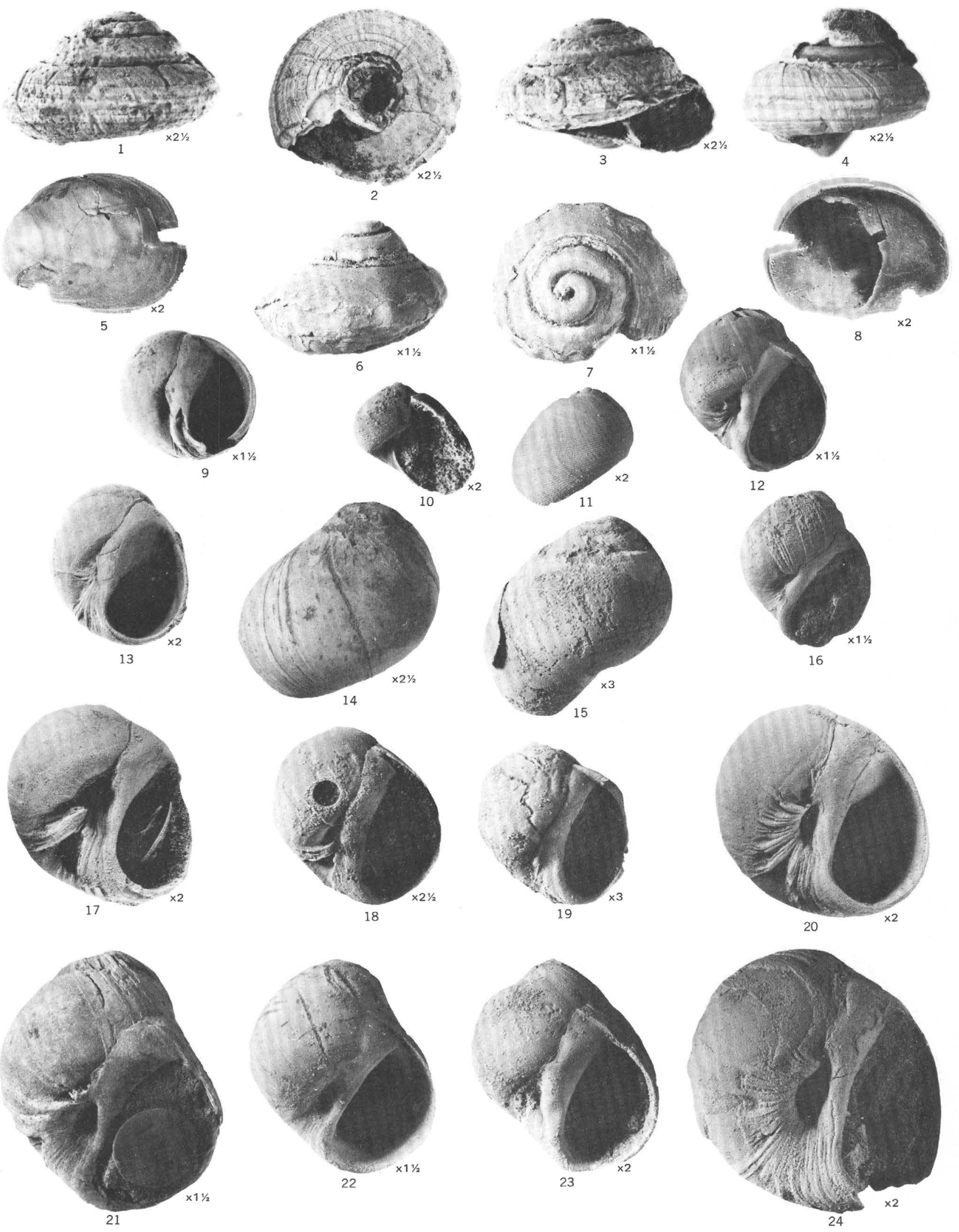

ARCHITECTONICA, CREPIDULA, UNIDENTIFED TROCHID?, CRYPTONATICA ,SINUM, AND POLINICES 


\section{PLATE 2}

Figures 1-15. Neverita (Glossaulax) thomsonae Hickman, p. 32

1. Height (incomplete) $34.0 \mathrm{~mm}$, width (incomplete) $36.5 \mathrm{~mm}$. Locality USGS 15264. USNM 213962.

2,5. Height (incomplete) $36.0 \mathrm{~mm}$, width (incomplete) $41.2 \mathrm{~mm}$. Locality USGS 5394. USNM 213963.

3. Height (incomplete) $39.6 \mathrm{~mm}$, width (incomplete) $37.7 \mathrm{~mm}$. Locality USGS 15264. USNM 213964.

4. Height (incomplete) $43.3 \mathrm{~mm}$, width (incomplete) $45.2 \mathrm{~mm}$. Locality USGS 15264. USNM 213965.

6. Height (incomplete) $21.5 \mathrm{~mm}$, width (incomplete) $21.7 \mathrm{~mm}$. Locality USGS M3878. USNM 213966.

7. Height (incomplete) $24.7 \mathrm{~mm}$, width (incomplete) $29.0 \mathrm{~mm}$. Locality USGS M3857. USNM 213967.

8, 12. Height $19.8 \mathrm{~mm}$, width (incomplete) $23.3 \mathrm{~mm}$. Locality USGS 15310. USNM 213968.

9. Height $15.3 \mathrm{~mm}$, width (incomplete) $10.4 \mathrm{~mm}$. Locality USGS 15310 . USNM 213969.

10. Height $44.7 \mathrm{~mm}$, width $49.6 \mathrm{~mm}$. Locality USGS 15264 . USNM 213970.

11. Height $18.3 \mathrm{~mm}$, width $19.6 \mathrm{~mm}$. Locality USGS 15310. USNM 213971.

13. Height $23.1 \mathrm{~mm}$, width (incomplete) $27.3 \mathrm{~mm}$. Locality USGS 15310. USNM 213972.

14. Height $52.5 \mathrm{~mm}$, width (incomplete) $46.5 \mathrm{~mm}$. Locality USGS 15310 . USNM 213973.

15. Height (incomplete) $36.0 \mathrm{~mm}$, width (incomplete) $36.6 \mathrm{~mm}$. Locality USGS M3871. USNM 213974. 
PROFESSIONAL PAPER 922 PLATE 2

GEOLOCICAL SURVEY
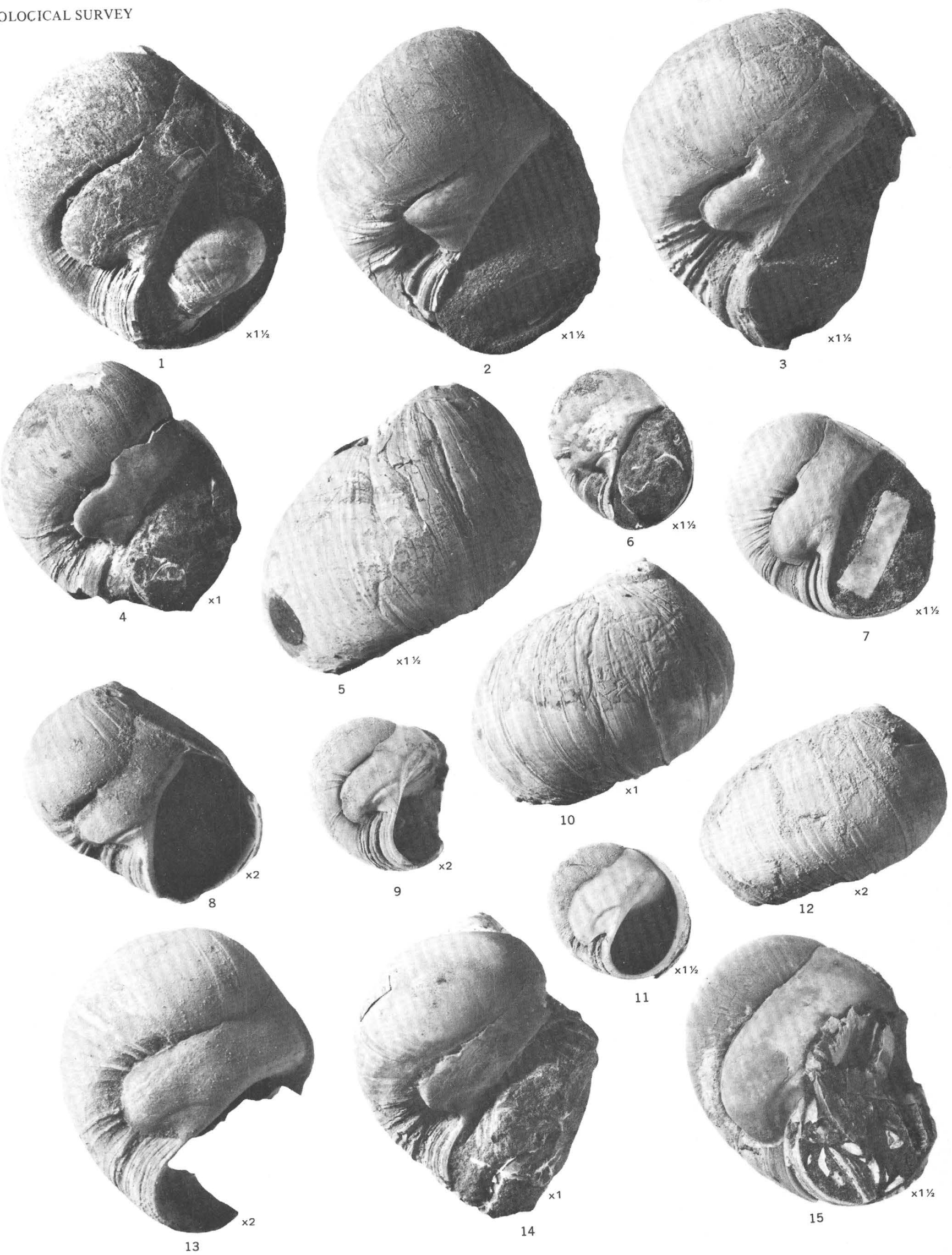

NEVERITA 


\section{PLATE 3}

Figures 1-5, 21-23. Bruclarkia columbiana (Anderson and Martin), p. 34

1. Height (incomplete) $59.5 \mathrm{~mm}$, width (incomplete) $48.3 \mathrm{~mm}$. Locality USGS 15264 . USNM 213975.

2. Height $12.6 \mathrm{~mm}$, width (incomplete) $8.0 \mathrm{~mm}$. Locality USGS 15310. USNM 213976.

3 , 4. Height (incomplete) $5.6 \mathrm{~mm}$, width (incomplete) $3.5 \mathrm{~mm}$. Locality USGS 15310. USNM 213977. Note protoconch on figure 3.

5. Height (incomplete) $44.7 \mathrm{~mm}$, width (incomplete) $30.5 \mathrm{~mm}$. Locality USGS 15264 . USNM 213978 .

21, 23. Height (incomplete) $68.5 \mathrm{~mm}$, width (incomplete) $52.7 \mathrm{~mm}$. Locality USGS 15588 . USNM 213979.

22. Height (incomplete) $59.5 \mathrm{~mm}$, width (incomplete) $14.5 \mathrm{~mm}$. Locality USGS 15310 . USNM 213980.

6, 8, 20. Opalia (Dentiscala?) hertleini, n. sp., p. 30

6. Height (incomplete) $6.6 \mathrm{~mm}$, width $3.8 \mathrm{~mm}$. Locality USGS 21612. USNM 213981.

8. Height (incomplete) $13.2 \mathrm{~mm}$, width (incomplete) $8.1 \mathrm{~mm}$. Locality USGS 15588 . USNM 213982.

20. Holotype. Height (incomplete) $29.7 \mathrm{~mm}$, width (incomplete) $12.0 \mathrm{~mm}$. Locality USGS 15588 . USNM 213983.

7, 9, 10. Odostomia winlockiana Effinger, p. 40

7. Height (incomplete) $4.5 \mathrm{~mm}$, width $2.2 \mathrm{~mm}$. Locality USGS 5329, Gries Ranch Formation. On the Nehalem road about 14,871 feet south of Clatskanie, sec. 24, T. 7 N., R. 5 W., Oregon. USNM 213984.

9, 10. Height $2.5 \mathrm{~mm}$, width $1.0 \mathrm{~mm}$. Locality USGS 15310. USNM 213985.

11-16. Turritella pittsburgensis, n. sp., p. 29

11. Height (incomplete) $21 \mathrm{~mm}$, width $6 \mathrm{~mm}$. Locality USGS 15278. USNM 213986.

12. Height (incomplete) $30 \mathrm{~mm}$, width $11 \mathrm{~mm}$. Locality USGS 15519. USNM 213987.

13. Height (incomplete) $33 \mathrm{~mm}$, width $12 \mathrm{~mm}$. Locality USGS 15519. USNM 213988.

14. Height (incomplete) $21 \mathrm{~mm}$, width $8 \mathrm{~mm}$. Locality USGS 15278. USNM 213989.

15. Height (incomplete) $30 \mathrm{~mm}$, width $11 \mathrm{~mm}$. Locality USGS 15519. USNM 213990.

16. Holotype. Height (incomplete) $28.6 \mathrm{~mm}$, width (incomplete) $10.7 \mathrm{~mm}$. Locality USGS 15588 . USNM 213991.

17-19. Priscofusus stewarti (Tegland), p. 36

17, 19. Height (incomplete) $29.6 \mathrm{~mm}$, width $12.7 \mathrm{~mm}$. Locality USGS 15264 . USNM 213992.

18. Height (incomplete) $16.7 \mathrm{~mm}$, width (incomplete) $10.6 \mathrm{~mm}$. Locality USGS M3871. USNM 213993. 

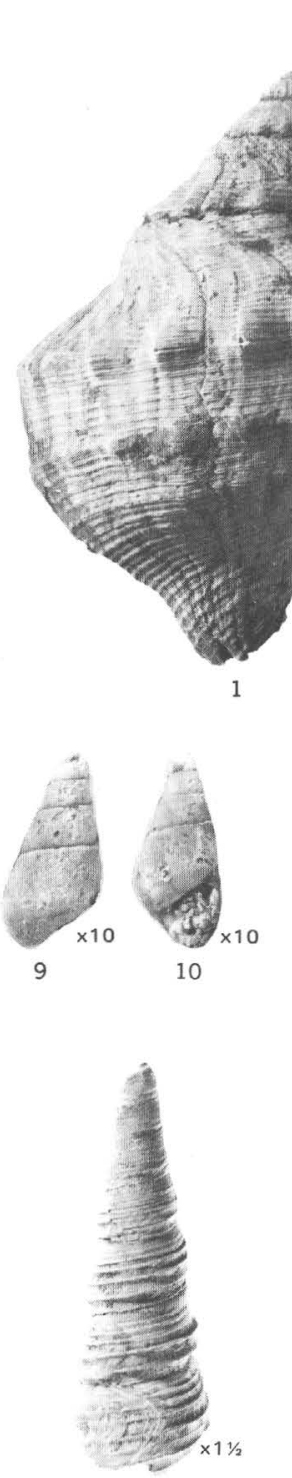

16
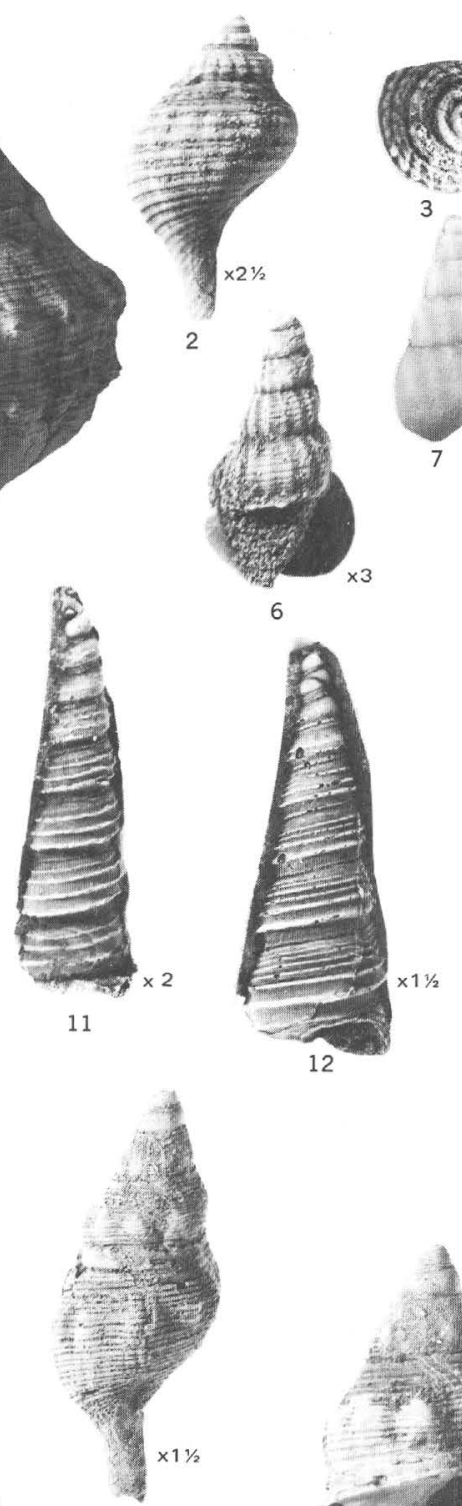

17
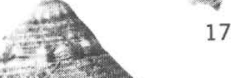

$x+2 x=4$

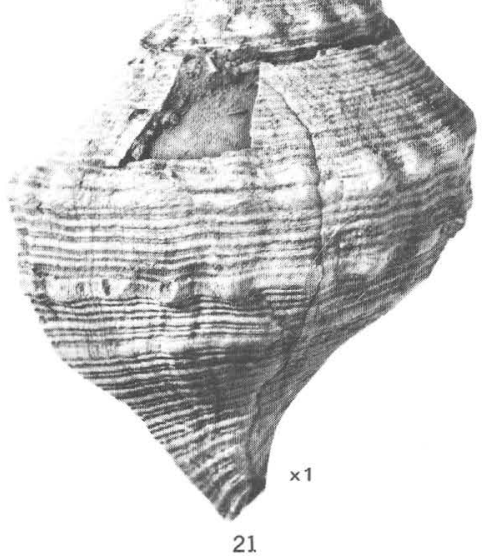

3
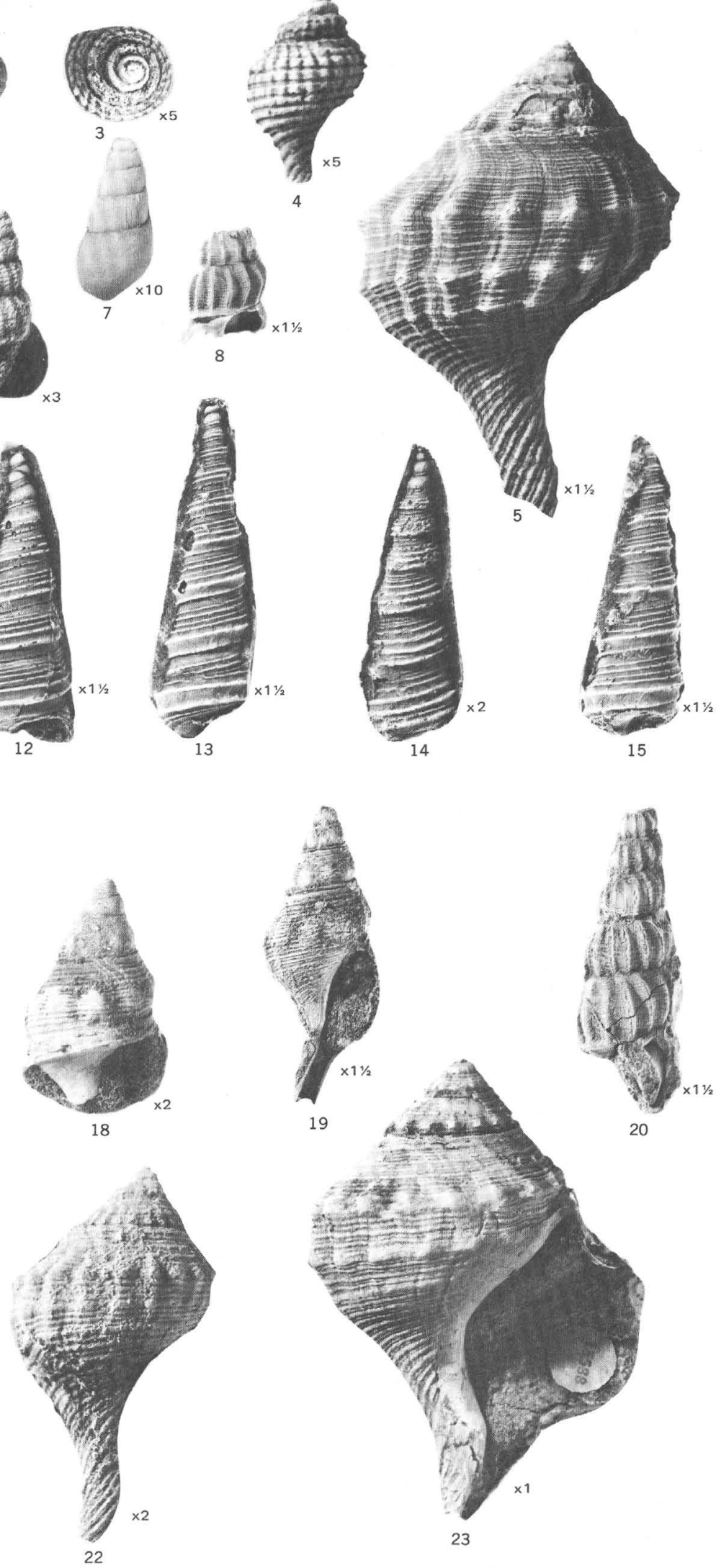

BRUCLARKIA, OPALIA, ODOSTOMIA, TURRITELLA, AND PRISCOFUSUS 


\section{PLATE 4}

FIgURES 1-9. Eosiphonalia oregonensis (Dall) p. 33

1, 3. Height $39.2 \mathrm{~mm}$, width $27.5 \mathrm{~mm}$. Locality USGS 15310 . USNM 213994.

2. Height $30.4 \mathrm{~mm}$, width $23.2 \mathrm{~mm}$. Locality USGS 15264 . USNM 213995.

4, 6. Holotype. Height $30 \mathrm{~mm}$, width $21 \mathrm{~mm}$. Locality UW 500. In fine-grained brownish-gray sandstone in road cut near Pittsburg, Columbia County, Oreg. USNM 107395.

5, 8. Height $32.8 \mathrm{~mm}$, width $24.5 \mathrm{~mm}$. Locality USGS 15264 . USNM 213996 7, 9. Height $31.2 \mathrm{~mm}$, width $23.7 \mathrm{~mm}$. Locality USGS 15310 . USNM 213997. 

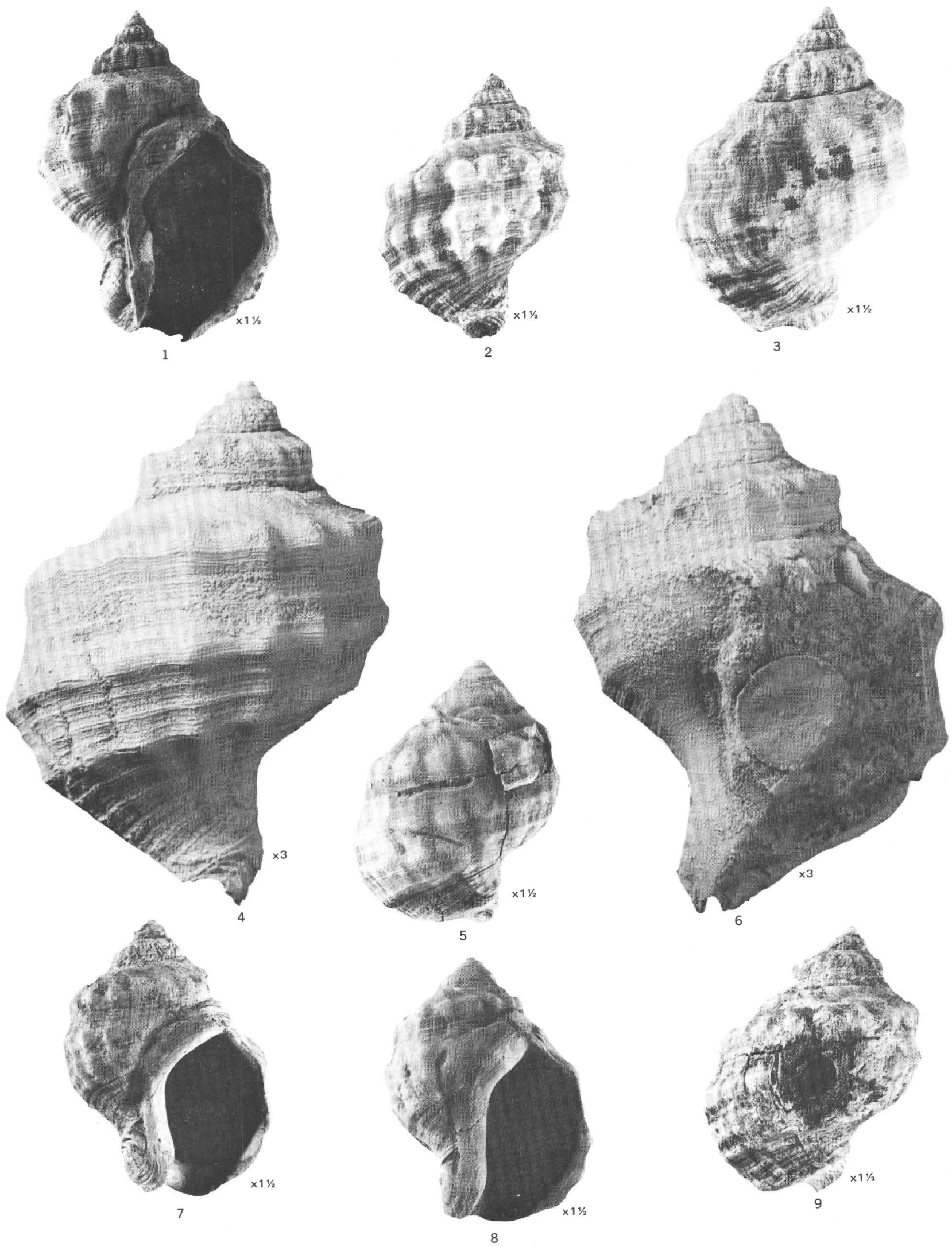

EOSIPHONALIA 


\section{PLATE 5}

Figures 1-22. Molopophorus gabbi Dall, p. 35

1, 2. Height (incomplete) $10.8 \mathrm{~mm}$, width (incomplete) $7.5 \mathrm{~mm}$. Locality USGS $15310 \mathrm{f}$. USNM 213998 .

3, 6. Height (incomplete) $16.8 \mathrm{~mm}$, width (incomplete) $12.6 \mathrm{~mm}$. Locality USGS 15264 . USNM 213999.

4. Protoconch. Locality USGS M3871. USNM 214000.

5. Height (incomplete) $16.7 \mathrm{~mm}$, width (incomplete) $13.7 \mathrm{~mm}$. Locality USGS 15310. USNM 214001.

7. Protoconch. Locality USGS M3857. USNM 214002.

8. Height (incomplete) $25.4 \mathrm{~mm}$, width (incomplete) $17.7 \mathrm{~mm}$. Locality USGS 15310. USNM 214003.

9. Height (incomplete) $17.3 \mathrm{~mm}$, width (incomplete) $20.0 \mathrm{~mm}$. Locality USGS 15310. USNM 214004 .

10. Height $27.8 \mathrm{~mm}$, width $20.9 \mathrm{~mm}$. Locality USGS 15310a. USNM 214005.

11. Height $27.0 \mathrm{~mm}$, width $21.3 \mathrm{~mm}$. Locality USGS 15310. USNM 214006.

12. Height $24.7 \mathrm{~mm}$, width $20.0 \mathrm{~mm}$. Locality USGS 15310. USNM 214007.

13. Height (incomplete) $26.2 \mathrm{~mm}$, width (incomplete) $20.7 \mathrm{~mm}$. Locality USGS 15310 . USNM 214008 .

14. Height (incomplete) $24.2 \mathrm{~mm}$, width (incomplete) $19.2 \mathrm{~mm}$. Locality USGS 15310. USNM 214009 .

15. Height (incomplete) $19.8 \mathrm{~mm}$, width (incomplete) $16.6 \mathrm{~mm}$, Locality USGS 15264 . USNM 21410.

16. Height $27.0 \mathrm{~mm}$, width $20.1 \mathrm{~mm}$. Locality USGS 15310. USNM 214011.

17. Height $26.6 \mathrm{~mm}$, width $21.0 \mathrm{~mm}$. Locality USGS 15310. USNM 214012

18. Height $24.7 \mathrm{~mm}$, width (incomplete) $21.5 \mathrm{~mm}$. Locality USGS 15310. USNM 214013.

19, 22. Holotype. Height $19 \mathrm{~mm}$, width $12 \mathrm{~mm}$. Locality USGS 2714. USNM 107377.

20. Height (incomplete) $23.7 \mathrm{~mm}$, width (incomplete) $17.0 \mathrm{~mm}$. Locality USGS 2415. USNM 214014 .

21. Paratype. Height (incomplete) $16 \mathrm{~mm}$, width $11.5 \mathrm{~mm}$. Locality USGS 2714. USNM 214016. 
GEOLOGICAL SURVEY

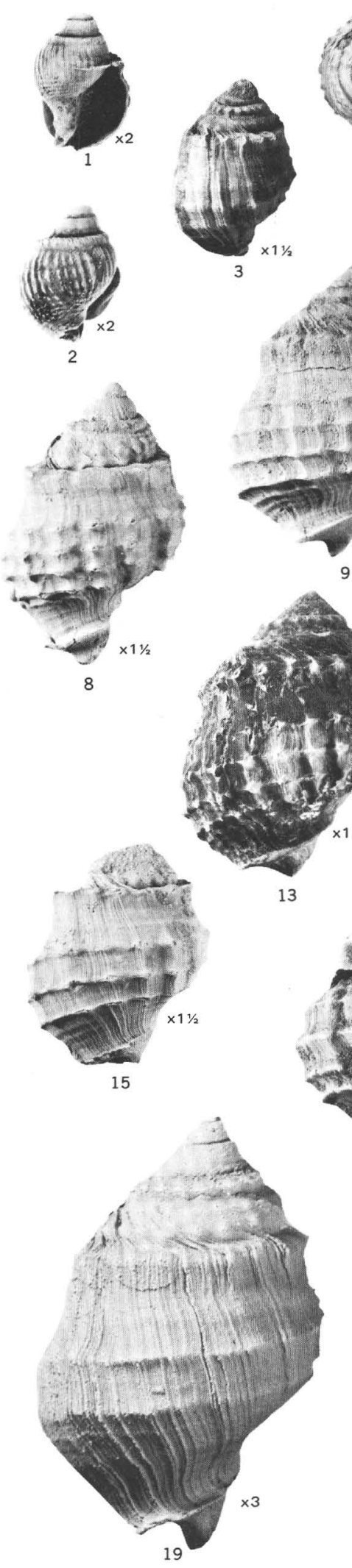

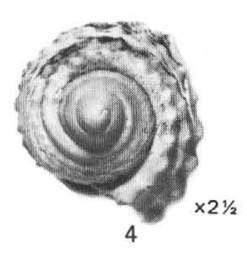
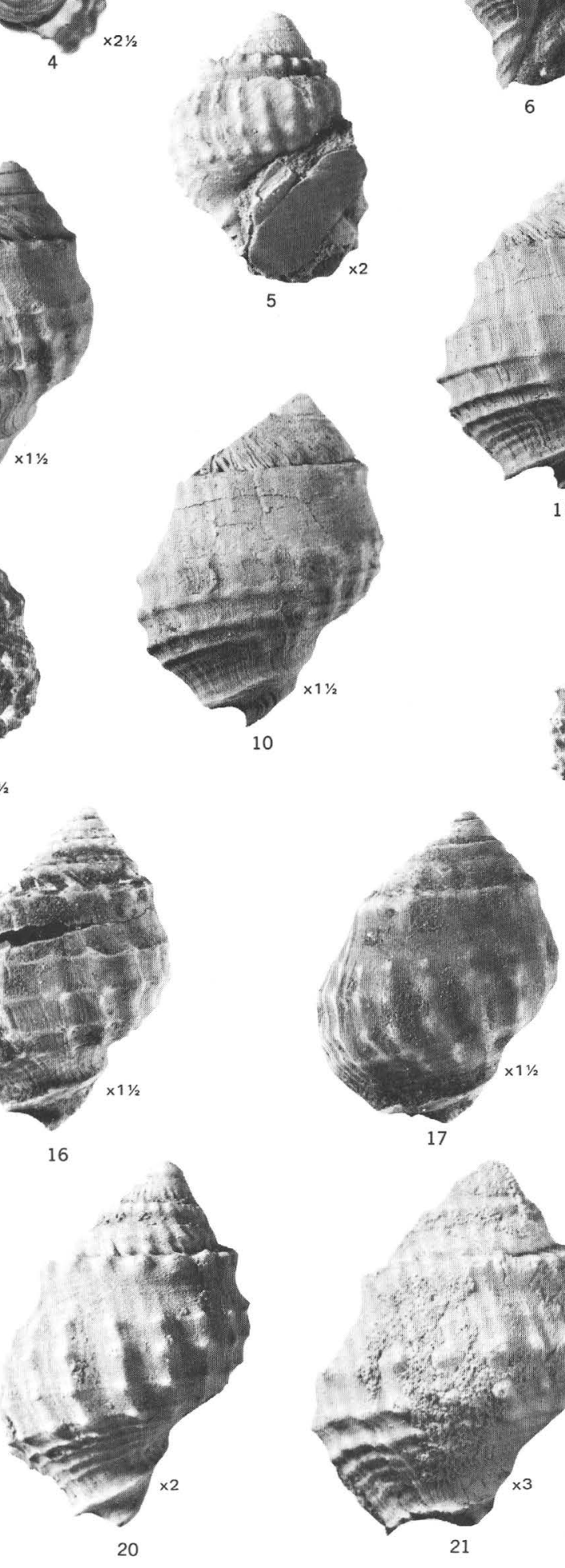
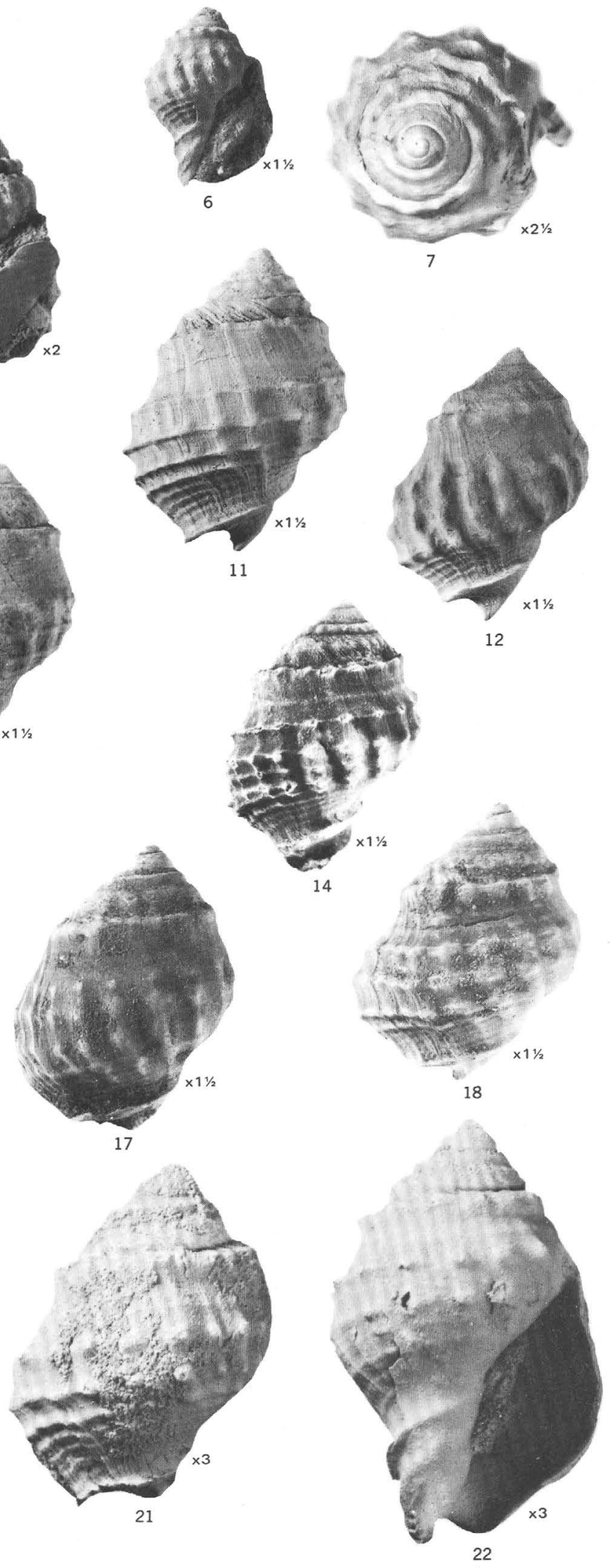

MOLOPOPHORUS 


\section{PLATE 6}

Figures 1, 4, 6, 7, 9, Perse pittsburgensis Durham, p. 36

12-14, 18-20. 1, 4. Height $32.3 \mathrm{~mm}$, width (incomplete) $15.8 \mathrm{~mm}$. Locality USGS 15264. USNM 214017.

6. Height (incomplete) $21.0 \mathrm{~mm}$, width (incomplete) $11.5 \mathrm{~mm}$. Locality USGS 15310 . USNM 214018.

7. Height (incomplete) $12.0 \mathrm{~mm}$, width (incomplete) $10.0 \mathrm{~mm}$. Locality USGS 15264 . USNM 214019.

9. Height (incomplete) $6.7 \mathrm{~mm}$, width (incomplete) $4.6 \mathrm{~mm}$. Locality USGS 15588. USNM 214020 .

12. Height (incomplete) $16.7 \mathrm{~mm}$, width (incomplete) $12.2 \mathrm{~mm}$. Locality USGS 15588 . USNM 214021.

13. Height (incomplete) $17.6 \mathrm{~mm}$, width (incomplete) $13.3 \mathrm{~mm}$. Locality USGS 15588 . USNM 214022 .

14. Height (incomplete) $15.4 \mathrm{~mm}$, width (incomplete) $11.5 \mathrm{~mm}$. Locality USGS 15588 . USNM 214023.

18. Protoconch. Locality USGS 15264b. USNM 214024.

19. Height (incomplete) $11.8 \mathrm{~mm}$, width (incomplete) $9.8 \mathrm{~mm}$. Locality USGS 15588 . USNM 214025.

20. Height (incomplete) $13.5 \mathrm{~mm}$, width (incomplete) $8.9 \mathrm{~mm}$. Locality USGS 15588 . USNM 214026.

$2,3,5,8$, Perse pittsburgensis vernoniensis, n. subsp., p. 37

10, 11, 15-17. 2, 3. Height (incomplete) $23.8 \mathrm{~mm}$, width (incomplete) $14.6 \mathrm{~mm}$. Locality USGS 15588 . USNM 214027.

5, 8. Height (incomplete) $30.4 \mathrm{~mm}$, width (incomplete) $15.1 \mathrm{~mm}$. Locality USGS 15588. Holotype USNM 214028.

10. Height (incomplete) $23.4 \mathrm{~mm}$, width (incomplete) $13.0 \mathrm{~mm}$. Locality USGS 15588 . USNM 214029 .

11. Height (incomplete) $27.6 \mathrm{~mm}$, width (incomplete) $19.4 \mathrm{~mm}$. Locality USGS 15588 . USNM 214030 .

15. Height (incomplete) $24.3 \mathrm{~mm}$, width (incomplete) $16.7 \mathrm{~mm}$. Locality USGS 15588 . USNM 214031.

16. Height (incomplete) $28.0 \mathrm{~mm}$, width (incomplete) $15.2 \mathrm{~mm}$, Locality USGS 15588 . USNM 214032 .

17. Height (incomplete) $23.0 \mathrm{~mm}$, width (incomplete) $11.6 \mathrm{~mm}$. Locality USGS 15588. USNM 214033. 
EOLOGICAL SURVEY
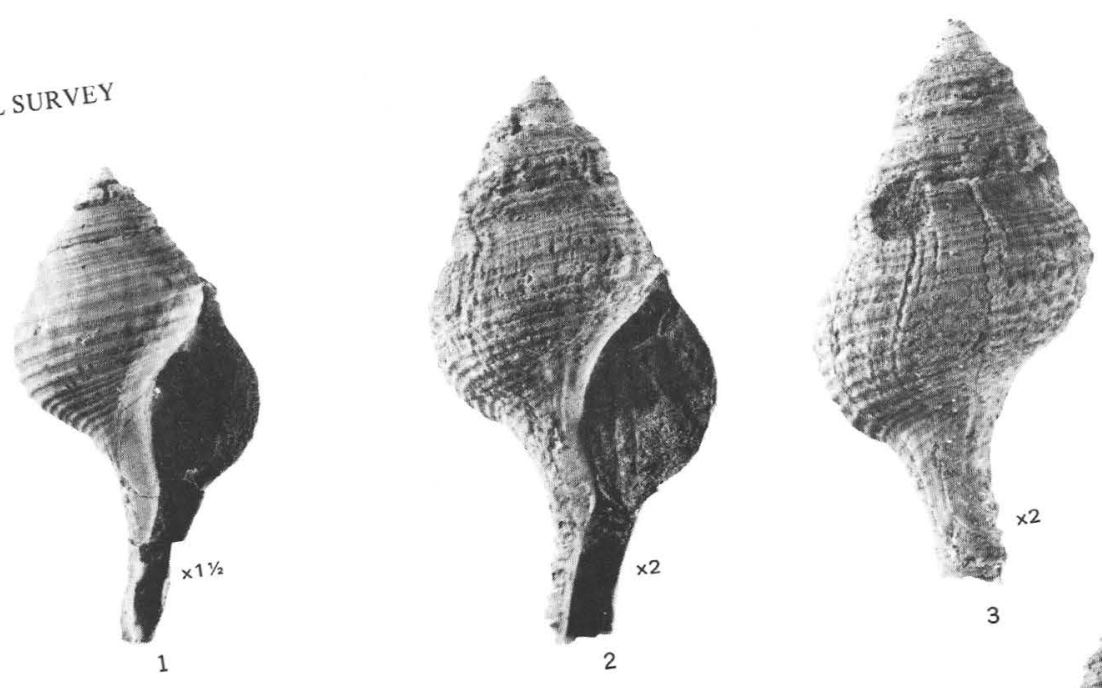

ESSIONAL PAPER 922 PLATE 6
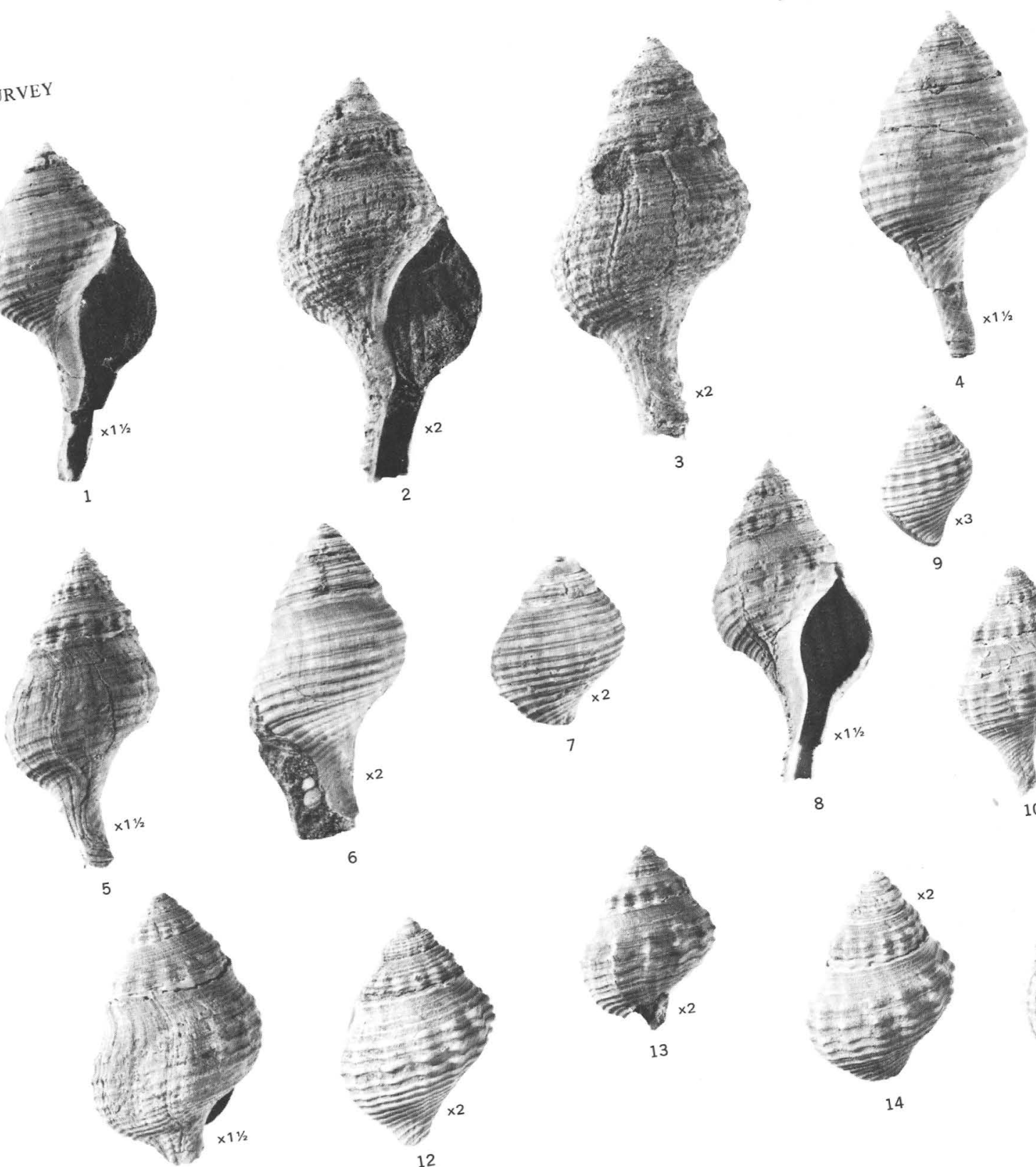

11
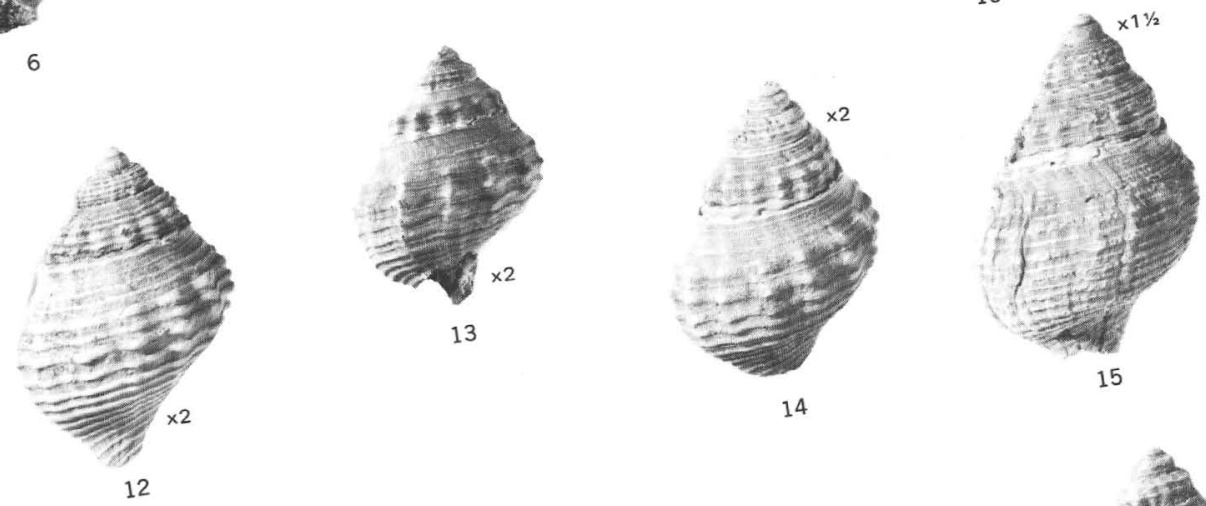

10
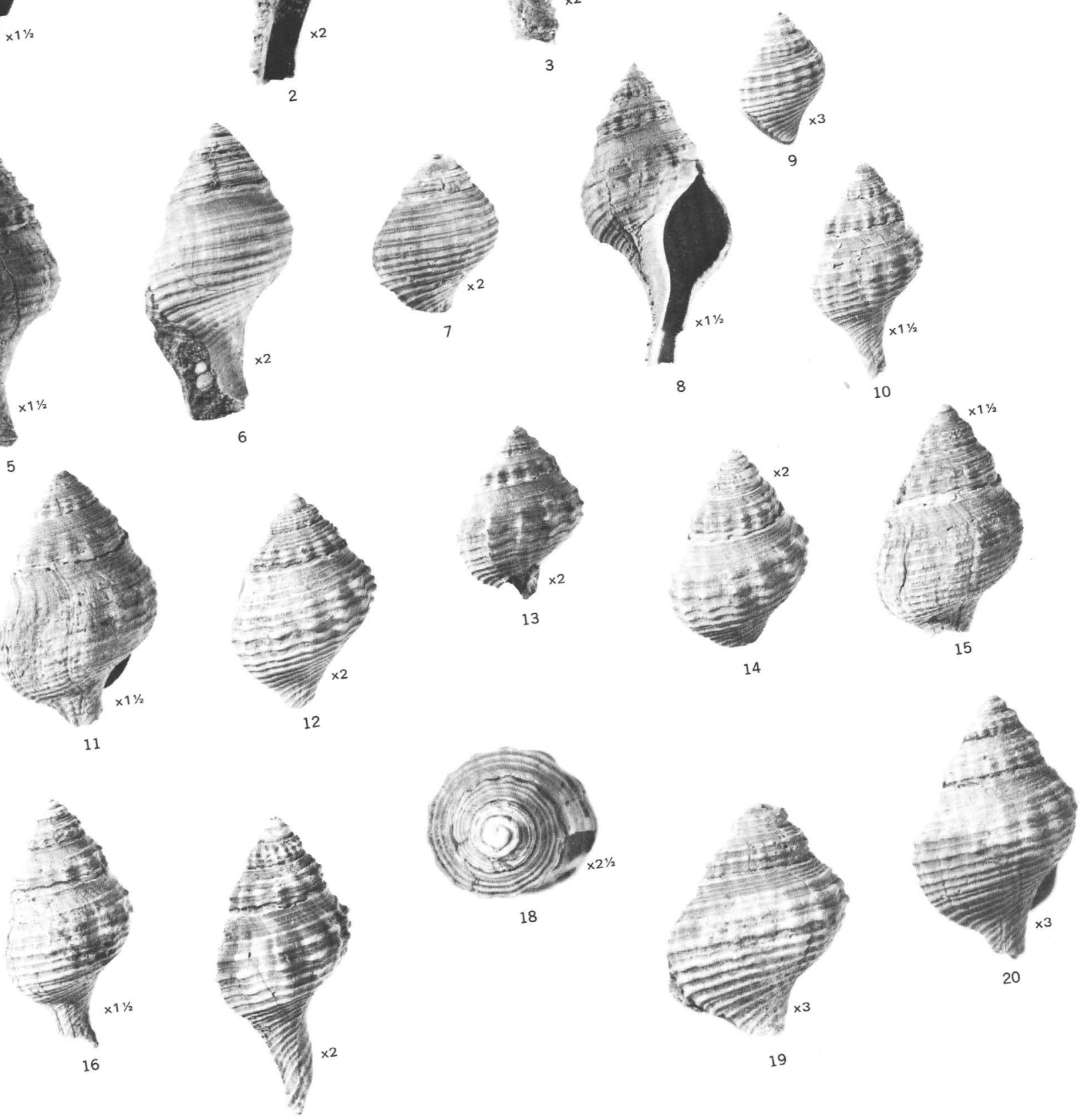

17 


\section{PLATE 7}

FIgURES 1, 9,10,13. Spirotropis kincaidi (Weaver), p. 39

1. Protoconch. Height (incomplete) $10.4 \mathrm{~mm}$, width (incomplete) $6.4 \mathrm{~mm}$. Locality USGS M3871. USNM 214034.

9. Height (incomplete) $17.2 \mathrm{~mm}$, width (incomplete) $7.8 \mathrm{~mm}$. Locality USGS 15588. USNM 214035.

10. Height $15.1 \mathrm{~mm}$, width (incomplete) $7.3 \mathrm{~mm}$. Locality USGS 15310a. USNM 225304.

13. Height (incomplete) $6.3 \mathrm{~mm}$, width (incomplete) $5.0 \mathrm{~mm}$. Locality USGS 15264. USNM 214036.

2, 3, 5-8, 16, 37. Taranis columbiana (Anderson and Martin) p. 38

2. Height (incomplete) $10.7 \mathrm{~mm}$, width (incomplete) $5.0 \mathrm{~mm}$. Locality USGS 15264a. USNM 214037.

3. Height (incomplete) $7.7 \mathrm{~mm}$, width (incomplete) $4.7 \mathrm{~mm}$. Locality USGS 15264. USNM 214038.

5. Height (incomplete) $10.8 \mathrm{~mm}$, width $4.9 \mathrm{~mm}$. Locality USGS M3871. USNM 214039.

6. Smooth-keeled form. Height (incomplete) $10.9 \mathrm{~mm}$, width (incomplete) $6.1 \mathrm{~mm}$. Locality USGS M3871. USNM 214040.

7. Height (incomplete) $8.1 \mathrm{~mm}$, width (incomplete) $4.3 \mathrm{~mm}$. Locality USGS 15310. USNM 214041.

8. Protoconch. Height $10.0 \mathrm{~mm}$, width (incomplete) $4.8 \mathrm{~mm}$. Locality USGS M3871. USNM 214042.

16. Smooth-keeled form. Height (incomplete) $9.6 \mathrm{~mm}$, width (incomplete) $5.0 \mathrm{~mm}$. Locality USGS 15264b. USNM 214043.

37. Intermediate form. Height (incomplete) $11.4 \mathrm{~mm}$, width (incomplete) $5.7 \mathrm{~mm}$. Locality USGS 15310 . USNM 214044.

$4,11,12,15$, Suavodrillia winlockensis (Effinger), p. 40

33-36, 38. 4. Protoconch. Height (incomplete) $8.0 \mathrm{~mm}$, width (incomplete) $4.0 \mathrm{~mm}$. Locality USGS 15310a. USNM 214045.

11. Height (incomplete) $3.5 \mathrm{~mm}$, width (incomplete) $1.8 \mathrm{~mm}$. Locality USGS 15310. USNM 214046.

12. Height (incomplete) $10.2 \mathrm{~mm}$, width (incomplete) $4.4 \mathrm{~mm}$. Locality USGS 15310. USNM 214047.

15. Height (incomplete) $4.9 \mathrm{~mm}$, width $2.4 \mathrm{~mm}$. Locality USGS 15310 . USNM 214048.

33. Height (incomplete) $6.0 \mathrm{~mm}$, width $3.3 \mathrm{~mm}$. Locality USGS 15264b. USNM 214049.

34. Height (incomplete) $5.1 \mathrm{~mm}$, width (incomplete) $2.2 \mathrm{~mm}$. Locality USGS 15310. USNM 214050.

35, 36. Height $10.6 \mathrm{~mm}$, width $4.5 \mathrm{~mm}$. Locality USGS 15310a. USNM 214051.

38. Height (incomplete) $6.9 \mathrm{~mm}$, width $3.2 \mathrm{~mm}$. Locality USGS 15310. USNM 214052.

14, 17. Dentalium (Fissidentalium?) laneensis Hickman, p. 41

14. Length (incomplete) 19.0, diameter: greatest $5.2 \mathrm{~mm}$, least $3.3 \mathrm{~mm}$. Locality USGS 2723. USNM 214053.

17. Length (incomplete) $30.6 \mathrm{~mm}$, diameter: greatest $10.0 \mathrm{~mm}$, least $5.3 \mathrm{~mm}$. Locality USGS 15264. USNM 214054 .

18, 23-32. Scaphander stewarti Durham, p. 41

18, 29. Height (incomplete) $10.9 \mathrm{~mm}$, width (incomplete) $6.0 \mathrm{~mm}$. Locality USGS 15264. USNM 214055.

23. Height (incomplete) $9.8 \mathrm{~mm}$, width (incomplete) $5.0 \mathrm{~mm}$. Locality USGS 15264b. USNM 214056.

24, 27. Height (incomplete) $8.8 \mathrm{~mm}$, width $4.9 \mathrm{~mm}$. Locality USGS 18638. USNM 214057.

25, 26. Height (incomplete) $13.8 \mathrm{~mm}$, width (distorted) $8.3 \mathrm{~mm}$. Locality USGS 15310. USNM 214058.

28. Height (incomplete) $10.7 \mathrm{~mm}$, width (incomplete) $6.1 \mathrm{~mm}$. Locality USGS 15264b. USNM 214059.

30, 31. Height $12.1 \mathrm{~mm}$, width $7.6 \mathrm{~mm}$. Locality USGS 15588. USNM 214060.

32. Height (incomplete) $9.4 \mathrm{~mm}$, width $9.0 \mathrm{~mm}$. Locality USGS 2714. USNM 214061

19. Acteon? n. sp.?, p. 41

Height (incomplete) $4.1 \mathrm{~mm}$, width (incomplete) $3.0 \mathrm{~mm}$. Locality USGS 15588. USNM 214062.

20, 21. Acteon chehalisensis (Weaver), p. 40

20. Height (incomplete) $8.2 \mathrm{~mm}$, width (incomplete) $4.4 \mathrm{~mm}$. Locality USGS 15264. USNM 214063.

21. Height (incomplete) $10.0 \mathrm{~mm}$, width (incomplete) $5.4 \mathrm{~mm}$. Locality USGS 15588. USNM 214064.

22. Aforia campbelli Durham, p. 37

Height (incomplete) $28.0 \mathrm{~mm}$, width (incomplete) $21.0 \mathrm{~mm}$. Locality USGS 15519. USNM 214065. 

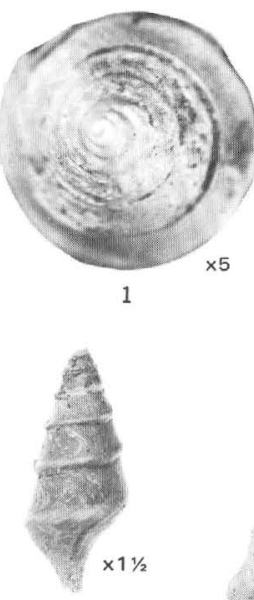

9

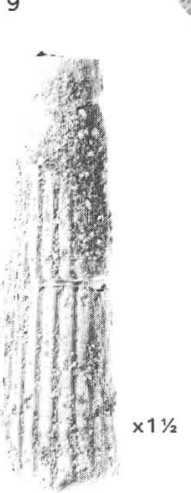

17

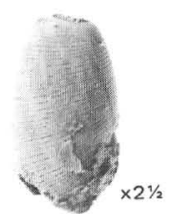

23

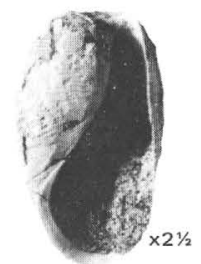

29

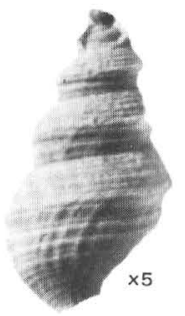

33
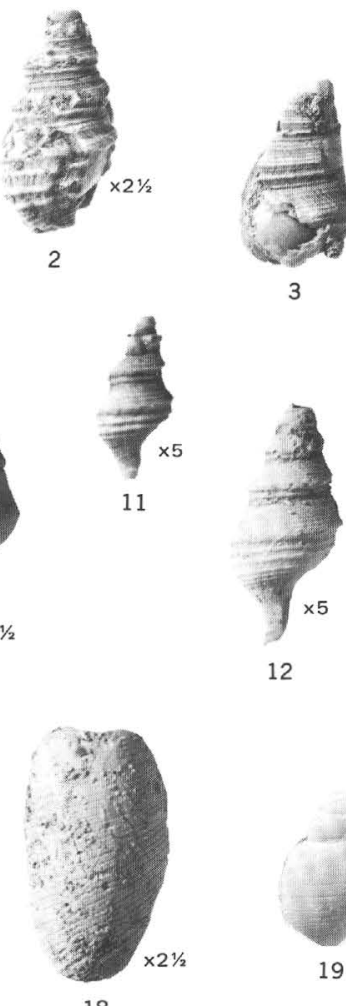

18
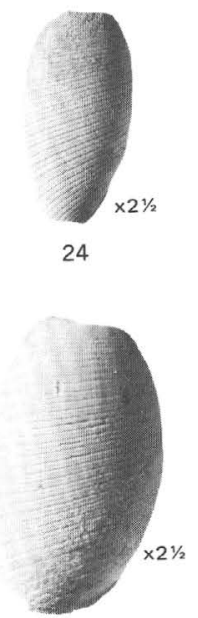

30

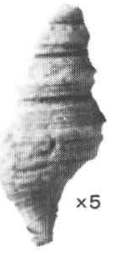

34
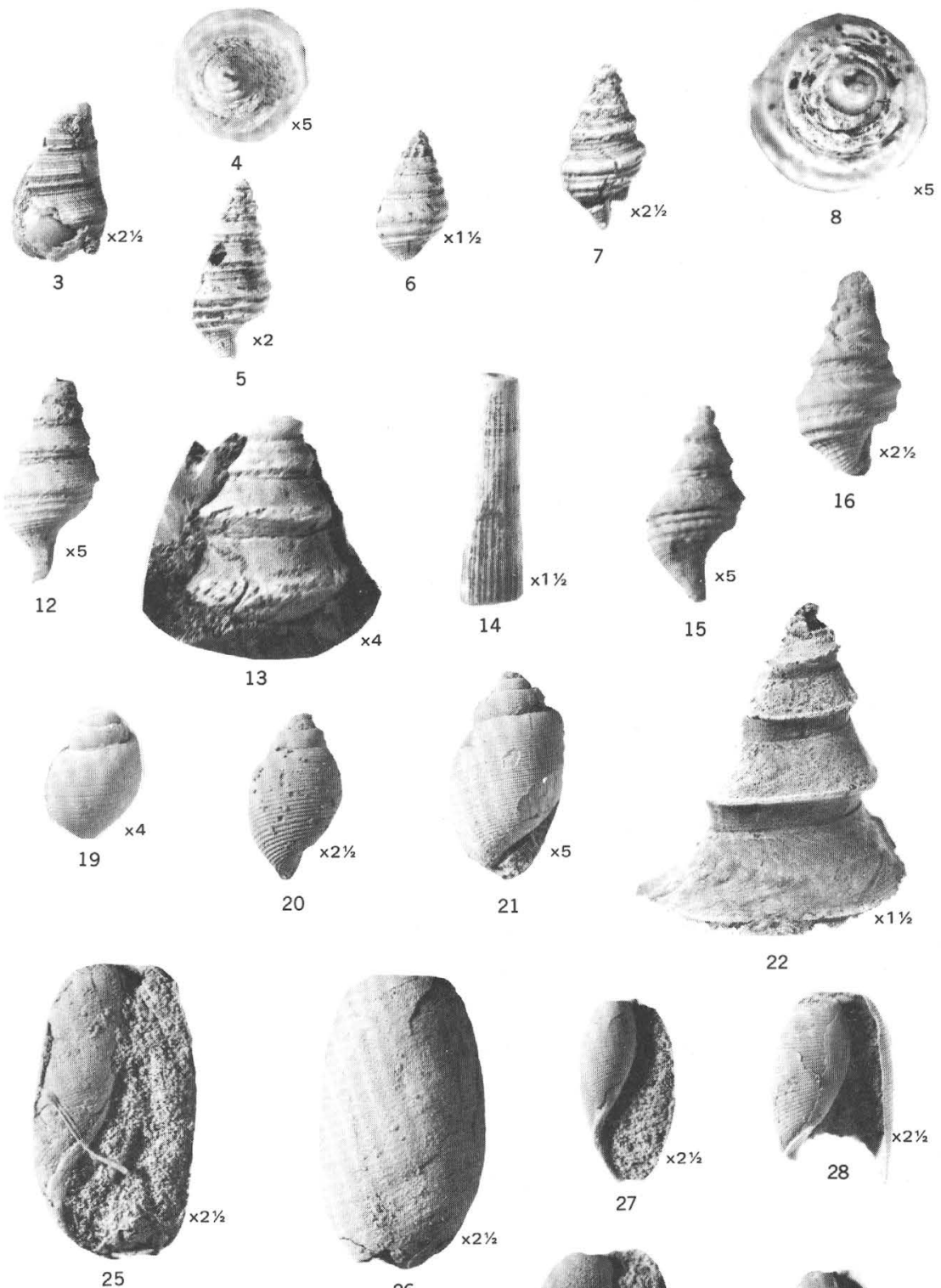

22
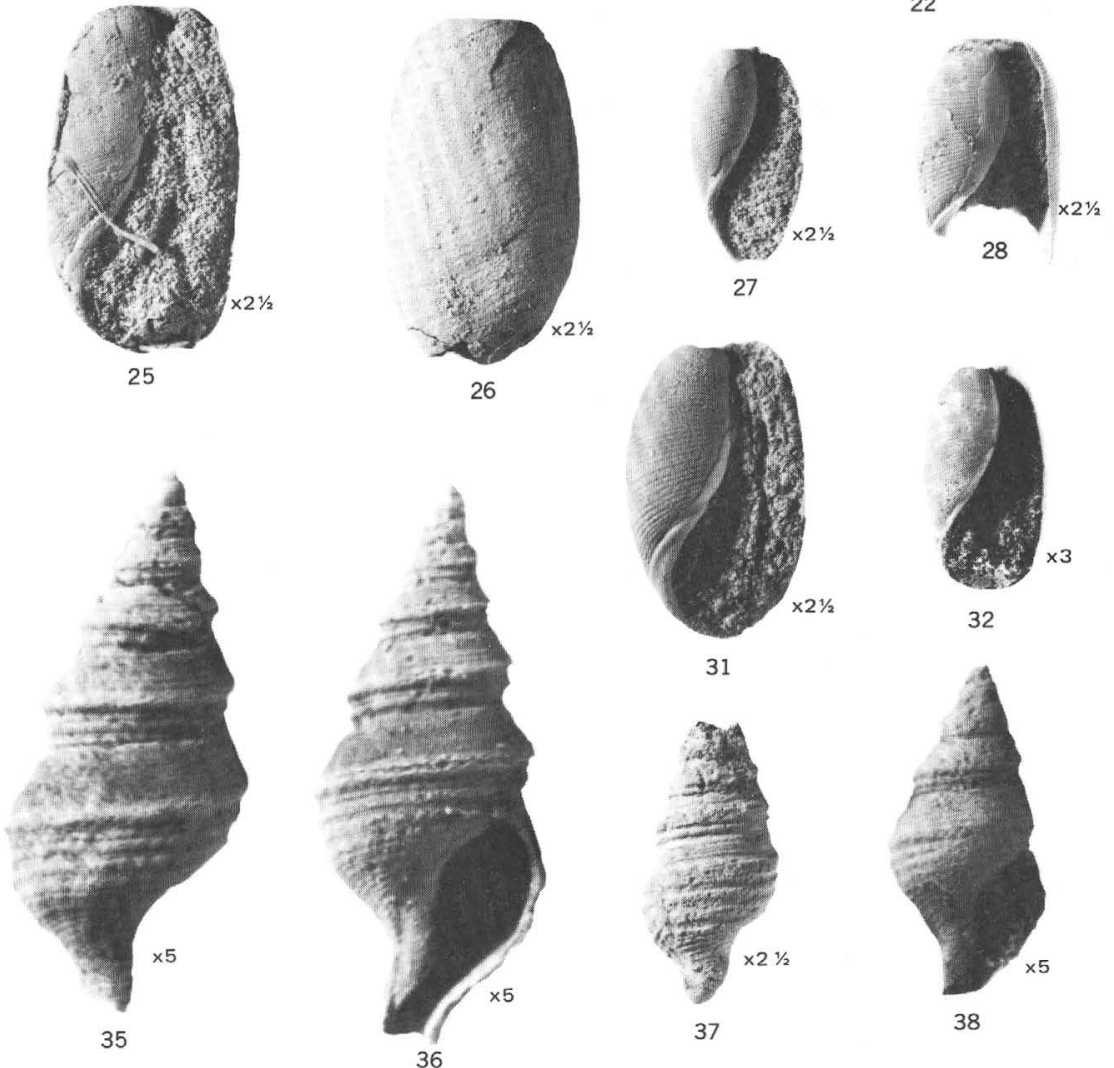

SPIROTROPIS, TARANIS, SUAVODRILLIA, DENTALIUM, SCAPHANDER, ACTEON?, ACTEON,AND AFORIA 


\section{PLATE 8}

Figures 1-9, 11, 12, Acila (Truncacila) shumardi (Dall), p. 42

$14,15,18$. 1. Length $18.0 \mathrm{~mm}$, width (both valves) $9.7 \mathrm{~mm}$, height $13.4 \mathrm{~mm}$. Locality USGS 15264. USNM 214066.

2, 3, 7. Length $24.4 \mathrm{~mm}$, width $14.5 \mathrm{~mm}$, height $18.7 \mathrm{~mm}$, Locality USGS 2714. USNM 107402.

2. End view of escutcheon.

3. Left valve.

7. Top view of lunule.

4. Length $28.0 \mathrm{~mm}$, width $7.7 \mathrm{~mm}$, height $20.2 \mathrm{~mm}$. Locality USGS 15310 . USNM 214067.

5, 6. Holotype. Length $24.2 \mathrm{~mm}$, height $17.8 \mathrm{~mm}$. Locality USGS 2714. USNM 406405.

8. Length $26.2 \mathrm{~mm}$, width (one valve) $7.5 \mathrm{~mm}$, height $19.9 \mathrm{~mm}$. Locality USGS 15588 . USNM 214068.

9. Length $14.1 \mathrm{~mm}$, width (one valve) $4.5 \mathrm{~mm}$, height $10.3 \mathrm{~mm}$. Locality USGS 15264. USNM 214069.

11. Length $25.1 \mathrm{~mm}$, width (one valve) $7.3 \mathrm{~mm}$, height $19.3 \mathrm{~mm}$. Locality USGS 15264 . USNM 214070.

12. Hinge. Length $23.0 \mathrm{~mm}$, height $16.8 \mathrm{~mm}$. Locality USGS M3871. USNM 214071.

14. Hinge. Length (incomplete) $22.9 \mathrm{~mm}$, height (incomplete) $18.0 \mathrm{~mm}$. Locality USGS M3871. USNM 214072.

15. Hinge. Length $26.6 \mathrm{~mm}$, height $19.9 \mathrm{~mm}$. Locality USGS M3871. USNM 214073.

18. Hinge. Length $23.3 \mathrm{~mm}$, height $16.9 \mathrm{~mm}$. Locality USGS M3871. USNM 214074.

10, 13, 16, 17. Nucula (Leionucula) vokesi, n. sp., p. 42

10. Holotype. Length $6.5 \mathrm{~mm}$, height $4.7 \mathrm{~mm}$. Locality USGS 18638. USNM 214075.

13. Length $7.5 \mathrm{~mm}$, width $3.2 \mathrm{~mm}$, height $5.7 \mathrm{~mm}$. Locality USGS 2714 . USNM 214076.

16. Hinge, left valve. Locality USGS 18638. USNM 214077.

17. Hinge, right valve. Locality USGS 18638. USNM 214078. 
GEOLOGICAL SURVEY
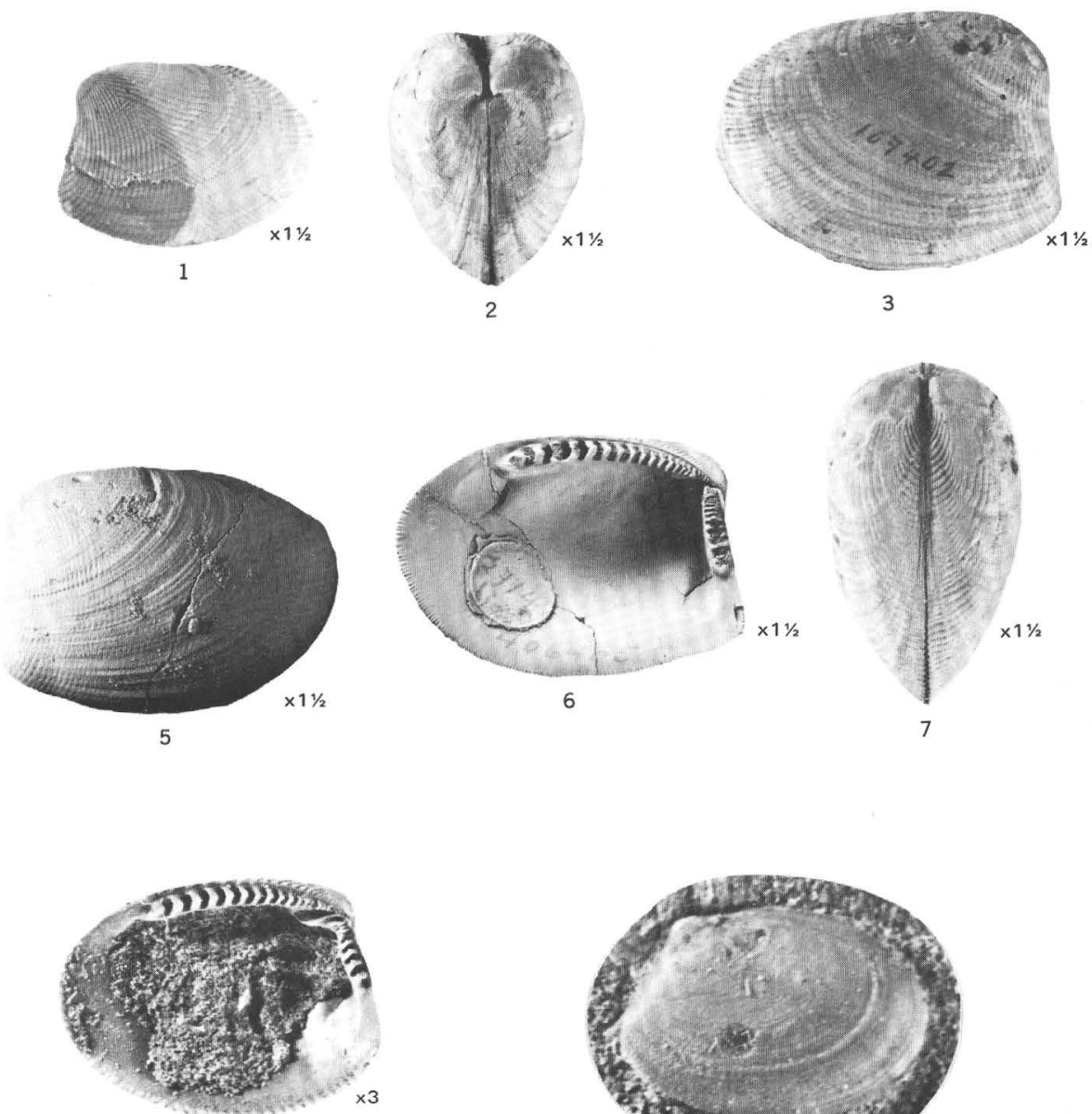

9

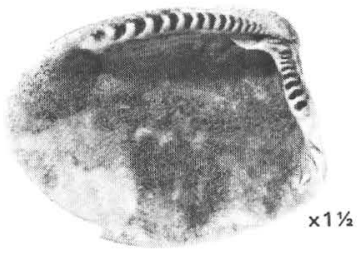

12
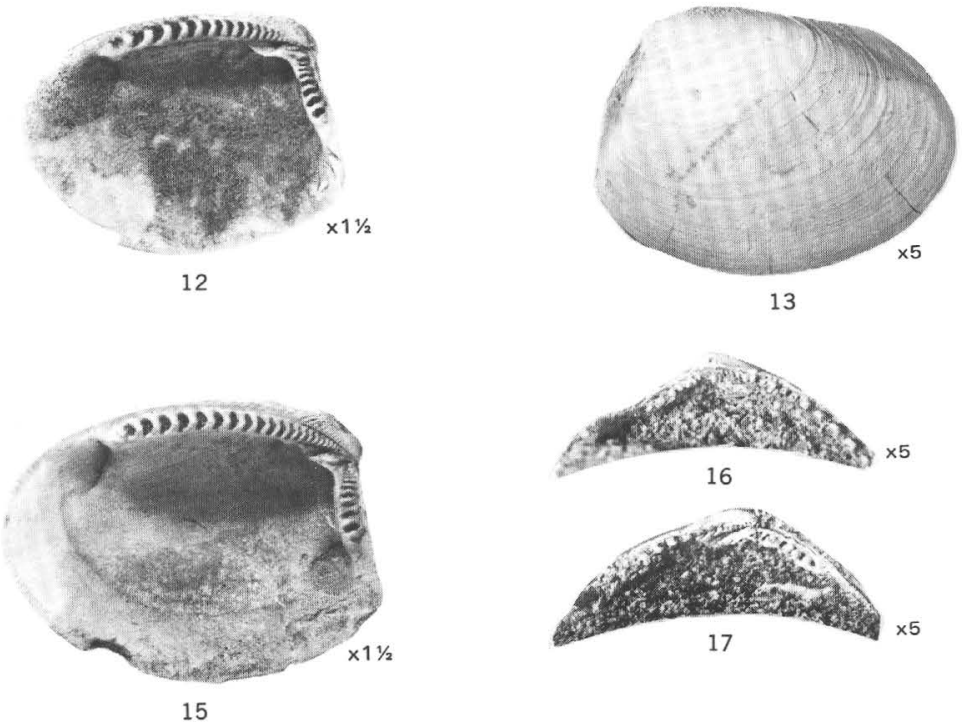

13

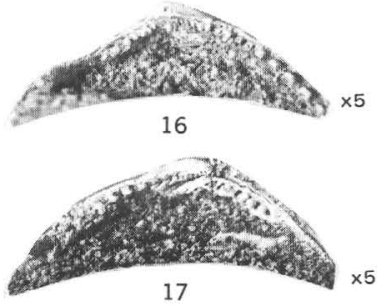

$A C I L A$ AND NUCULA
PROFESSIONAL PA PER 922 PLATE 8
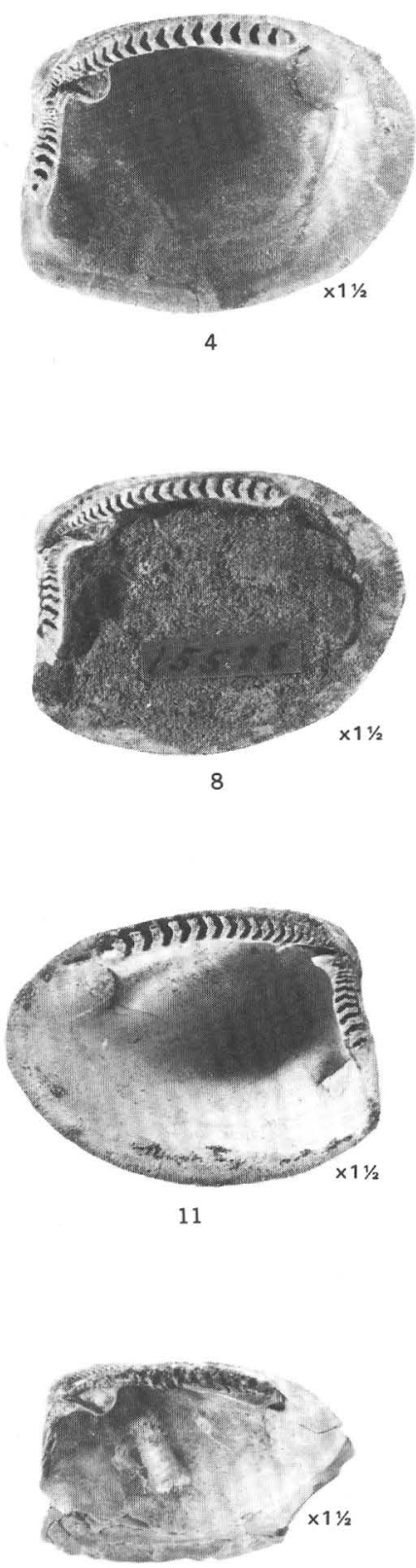

14

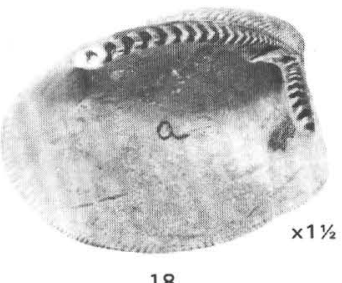

18 


\section{PLATE 9}

FigurEs 1-10, 12. Litorhadia washingtonensis (Weaver) p. 43

1. Length (incomplete) $22.7 \mathrm{~mm}$, height (incomplete) $12.3 \mathrm{~mm}$, width $3.0 \mathrm{~mm}$. Locality USGS 15310. USNM 214079.

2, 8. Length (incomplete) $17.1 \mathrm{~mm}$, height (incomplete) $8.1 \mathrm{~mm}$. Locality USGS 19004, Lincoln Creek Formation, Washington. USNM 214080.

3. Length (incomplete) $23 \mathrm{~mm}$, height (incomplete) $12 \mathrm{~mm}$. Locality USGS 15310 . USNM 214081 .

4. Length (incomplete) $17.6 \mathrm{~mm}$, height (incomplete) $10.5 \mathrm{~mm}$. Locality USGS 18638 . USNM 214082.

5. Length (incomplete) $20.4 \mathrm{~mm}$, height $10.2 \mathrm{~mm}$. Locality USGS 15310 . USNM 214083.

6. Length (incomplete) $19.5 \mathrm{~mm}$, height (incomplete) $9.3 \mathrm{~mm}$. Locality USGS 18638. USNM 214084.

7. Length (incomplete) $16.2 \mathrm{~mm}$, height (incomplete) $7.5 \mathrm{~mm}$. Locality USGS 15310 . USNM 214085.

9. Length (incomplete) $11.0 \mathrm{~mm}$, height (incomplete) $5.2 \mathrm{~mm}$. Locality USGS 15588. USNM 214086.

10. Length $20.0 \mathrm{~mm}$, height $9.3 \mathrm{~mm}$. Locality USGS 15264 . USNM 214087.

12. Length $29.2 \mathrm{~mm}$, height $13.7 \mathrm{~mm}$. Locality USGS 15588. USNM 214088.

11, 13, 15. Cyclocardia (Cyclocardia) cf. C. (C.) hannibali (Clark), p. 45

11. Length (incomplete) $17.6 \mathrm{~mm}$, height (incomplete) $17.8 \mathrm{~mm}$. Locality USGS 15537 . USNM 214089.

13. Length (incomplete) $15.5 \mathrm{~mm}$, height (incomplete) $12.0 \mathrm{~mm}$. Locality USGS 15537 . USNM 214090.

15. Right valve and hinge of left valve. Length (incomplete) $14.0 \mathrm{~mm}$, height (incomplete) 13.0 mm. Locality USGS 15537. USNM 214091.

14, 16-18. Yoldia (Kalayoldia) oregona (Shumard), p. 44

14. Length (incomplete) $43 \mathrm{~mm}$, height $28.0 \mathrm{~mm}$. Locality USGS 15586 . USNM 214092.

16. Hinge. Locality USGS 15310a. USNM 214093.

17. Length (incomplete) $41.4 \mathrm{~mm}$, height $23.0 \mathrm{~mm}$. Locality USGS 15586 . USNM 214094

18. Length (incomplete) $51 \mathrm{~mm}$, height (incomplete) $23 \mathrm{~mm}$. Locality USGS 15264e. USNM 214095 . 

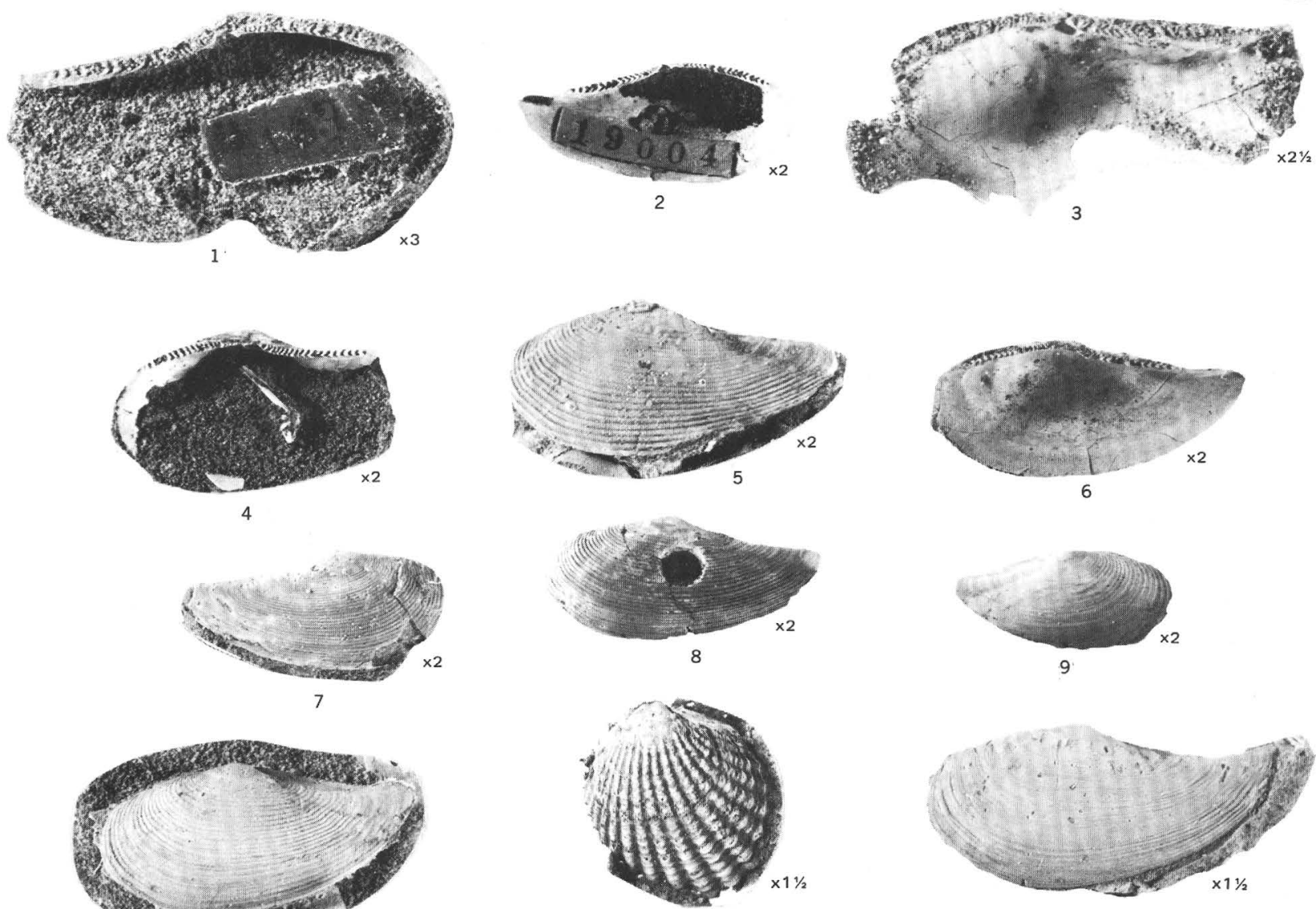

11
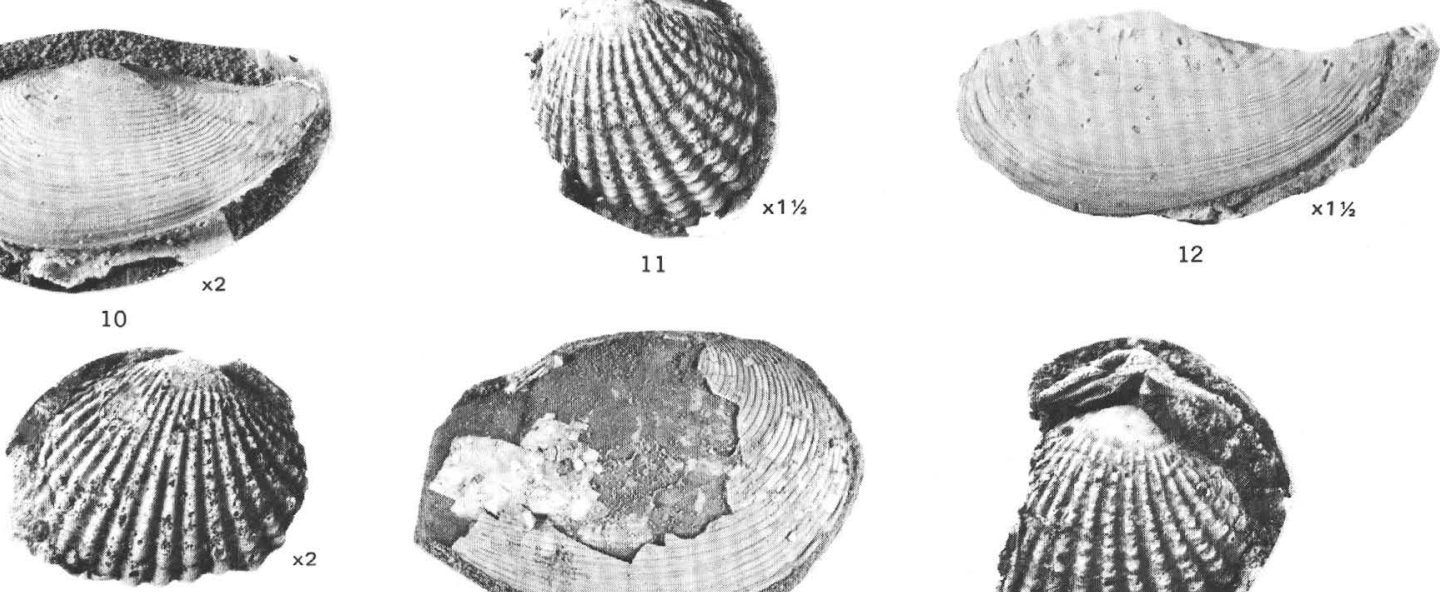

13
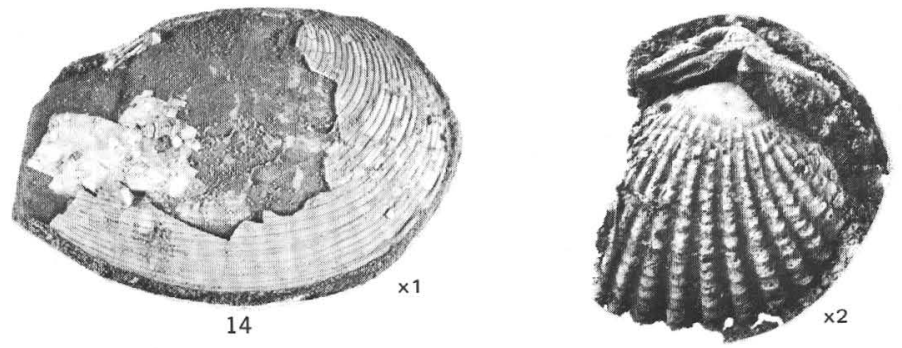

15

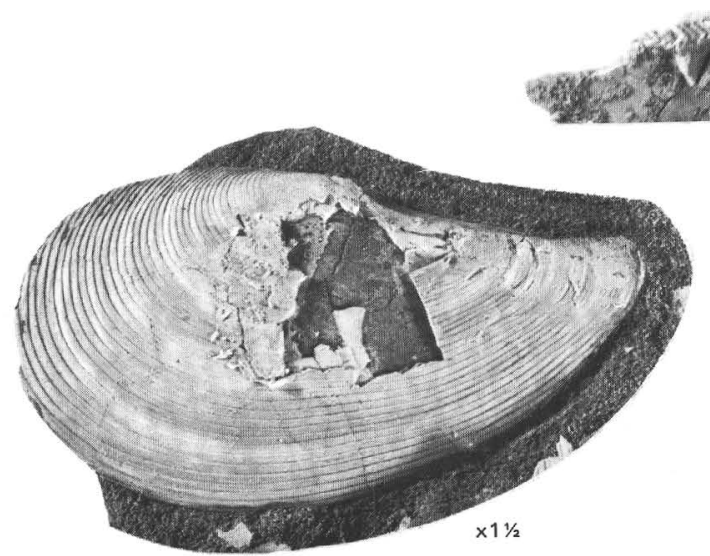

17

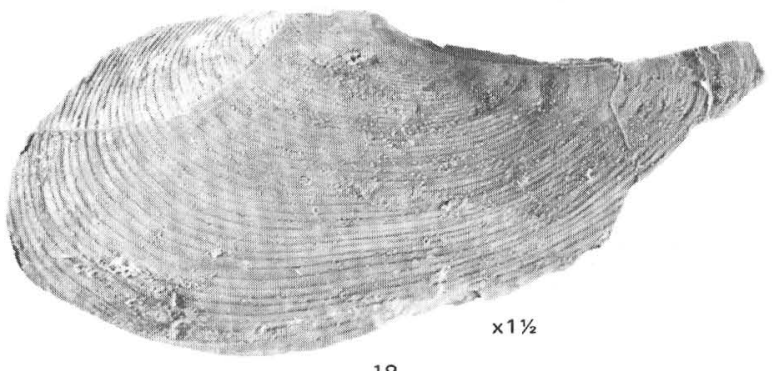

18

LITORHADIA, CYCLOCARDIA, AND YOLDIA 


\section{PLATE 10}

Figures 1-8. Lucinoma columbiana (Clark and Arnold), p. 45

1. Length (incomplete) $18.7 \mathrm{~mm}$, height $15.5 \mathrm{~mm}$. Locality USGS 15588 . USNM 214096.

2, 3, 6-8. Length (incomplete) $21.2 \mathrm{~mm}$, height $20.0 \mathrm{~mm}$, width (both valves) $11.6 \mathrm{~mm}$. Locality USGS 15588. USNM 214097.

4, 5. Length $11.0 \mathrm{~mm}$, height $10.3 \mathrm{~mm}$, width (one valve) $2.3 \mathrm{~mm}$, Locality USGS 15588. USNM 214098.

9-11. Felaniella (Felaniella) snavelyi, n. sp., p. 46

9. Length $14.6 \mathrm{~mm}$, height $13.0 \mathrm{~mm}$. Locality USGS 15586 . USNM 214099.

10. Holotype. Length $21.6 \mathrm{~mm}$, height $19.6 \mathrm{~mm}$, width (one valve) $4.2 \mathrm{~mm}$. Locality USGS 15264. USNM 214100.

11. Length (incomplete) $15.0 \mathrm{~mm}$, height $22.0 \mathrm{~mm}$. Locality USGS 15310 . USNM 214101.

12-14. Nemocardium (Keenaea) lorenzanum (Arnold), p. 47

12. Length (incomplete) $11 \mathrm{~mm}$, height (incomplete) $10.0 \mathrm{~mm}$. Locality USGS 18638. USNM 214102.

13. Length $12.3 \mathrm{~mm}$, height $11.0 \mathrm{~mm}$. Locality USGS 15264 . USNM 214103.

14. Height $4.5 \mathrm{~mm}$, length $4.6 \mathrm{~mm}$. Locality USGS 18638. USNM 214104. 

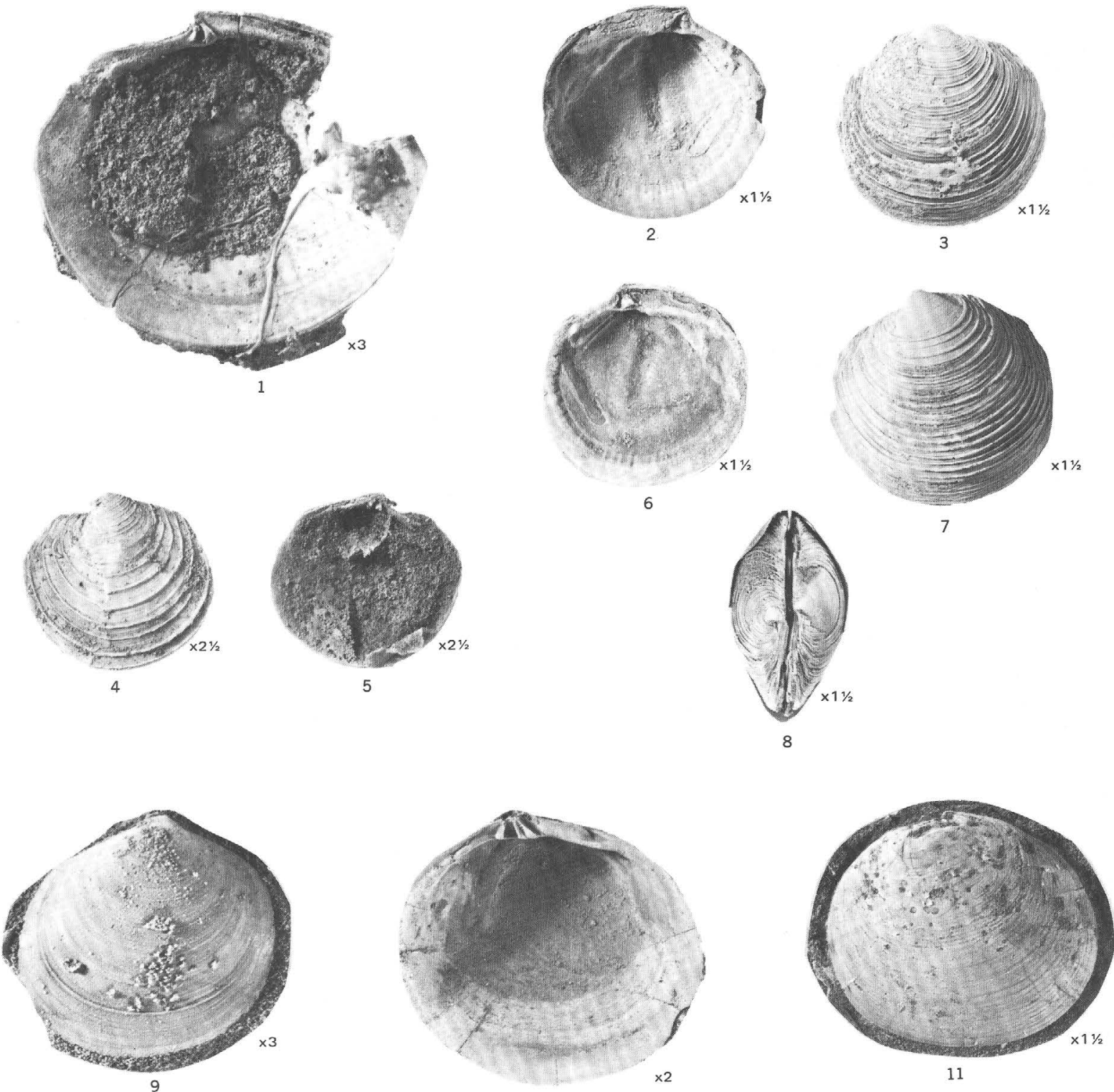

10
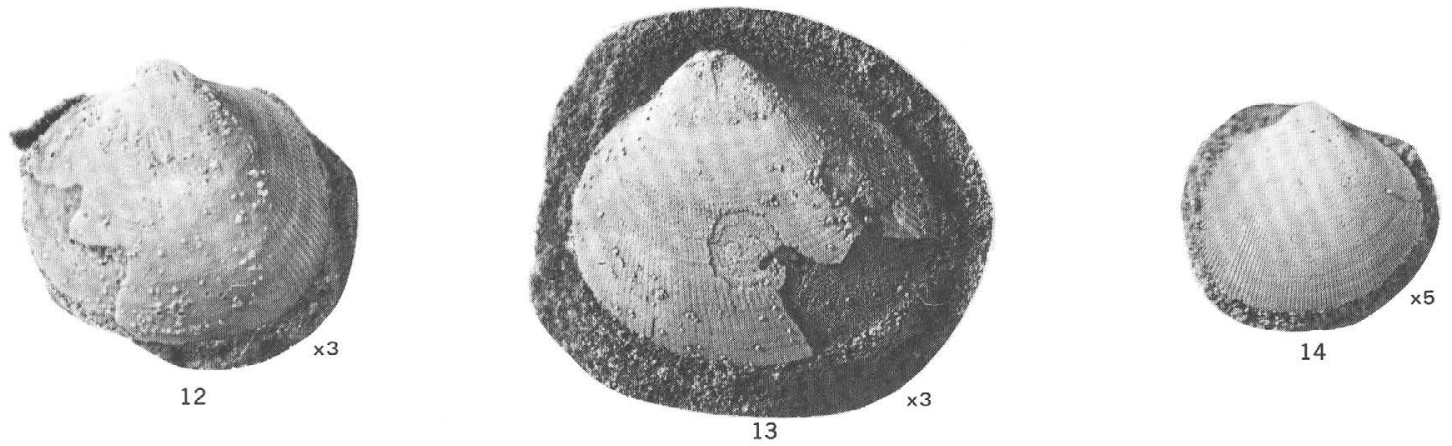

LUCINOMA, FELANIELLA, AND NEMOCARDIUM 


\section{PLATE 11}

Figures 1-6. Tellina? pittsburgensis Clark, p. 51

1. Hinge. Locality USGS 15264. USNM 214105.

2. Hinge. Locality USGS 15264 . USNM 214106.

3. Length (incomplete) $13.7 \mathrm{~mm}$, height (incomplete) $8.4 \mathrm{~mm}$. Locality USGS 15586. USNM 214107.

4. Length (incomplete) $15.6 \mathrm{~mm}$, height (incomplete) $9.6 \mathrm{~mm}$. Locality USGS 15586. USNM 214108.

5. Dorsal view. Length (incomplete) $22 \mathrm{~mm}$, height $13.4 \mathrm{~mm}$, width (both valves) $5.4 \mathrm{~mm}$. Locality USGS 15264. USNM 214109.

6. Height $13.3 \mathrm{~mm}$, length (incomplete) $21.6 \mathrm{~mm}$. Locality USGS 15264 . USNM 214110.

7-12. Tellina (Eurytellina) aduncanasa Hickman, p. 50

7. Length (incomplete) $36 \mathrm{~mm}$, height (incomplete) $20 \mathrm{~mm}$. Locality USGS 15588. USNM 214111.

$8,11,12$. Length (incomplete) $18.6 \mathrm{~mm}$, height (incomplete) $9.7 \mathrm{~mm}$, width (both valves) $2.8 \mathrm{~mm}$. Locality USGS 15264. USNM 214112.

9. Length (incomplete) $39 \mathrm{~mm}$, height (incomplete) $19 \mathrm{~mm}$. Locality USGS 15310b. USNM 214113.

10. Length (incomplete) $27 \mathrm{~mm}$, height (incomplete) $14 \mathrm{~mm}$. Locality USGS 15586. USNM 214114 

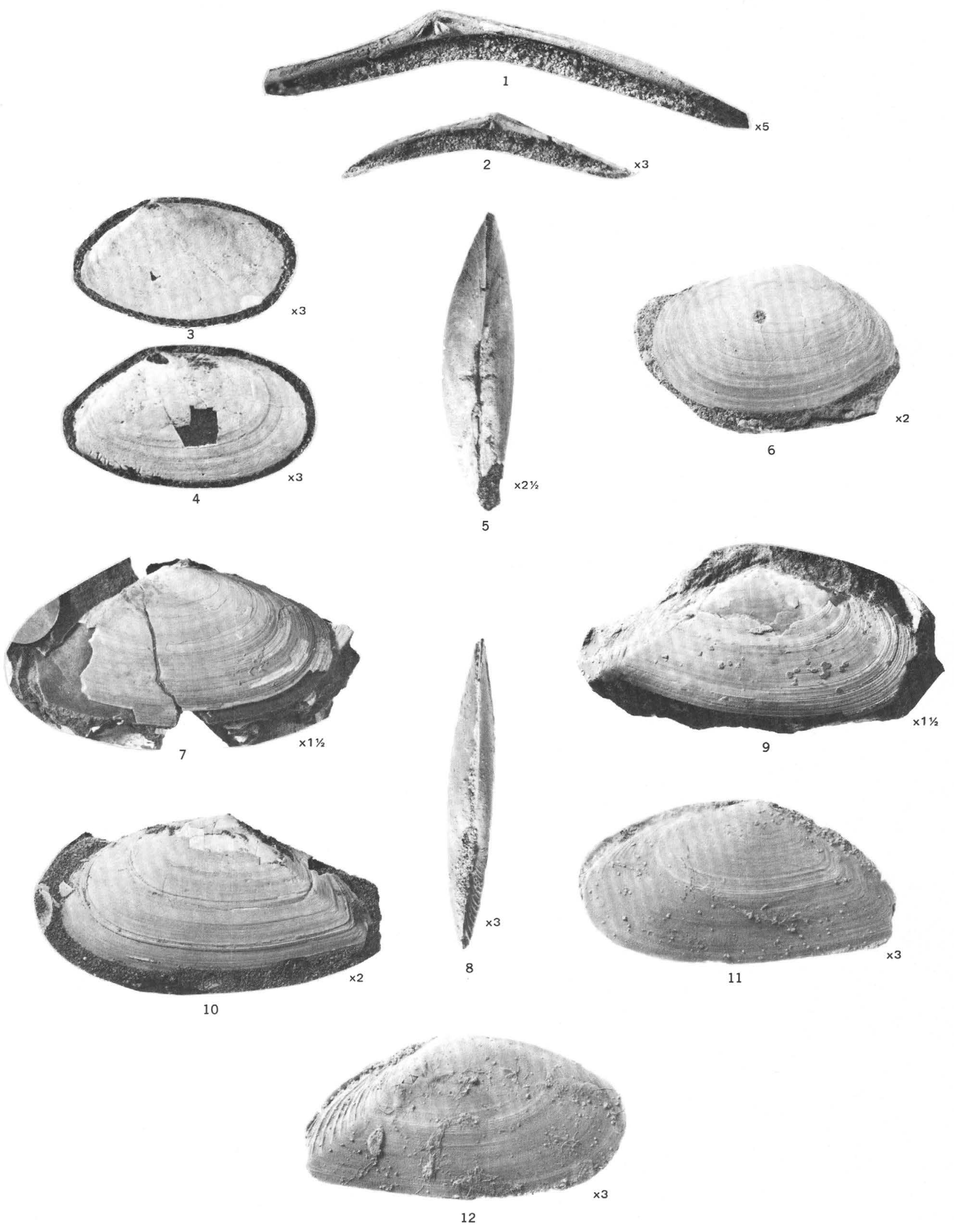

TELLINA? AND TELLINA 


\section{PLATE 12}

Figures 1, 2, 4. Pitar (Pitar) dalli (Weaver), p. 47

1, 4. Length (incomplete) $65 \mathrm{~mm}$, height (incomplete) $46 \mathrm{~mm}$, width (both valves, internal mold) $28.5 \mathrm{~mm}$. Locality USGS 15532. USNM 214115.

2. Left hinge. Locality USGS 15310a. USNM 214116.

3, 5-11, 13. Callista (Macrocallista) pittsburgensis Dall, p. 48

3. Left hinge. Length $13.0 \mathrm{~mm}$, height $8.6 \mathrm{~mm}$. Locality USGS 15264 . USNM 214177.

5. Left hinge. Length $19.3 \mathrm{~mm}$, height $13.0 \mathrm{~mm}$. Locality USGS 15264 . USNM 214118.

6. Length (incomplete) $42 \mathrm{~mm}$, height $24.3 \mathrm{~mm}$. Locality USGS 15264. USNM 214119.

7, 9. Length $34.0 \mathrm{~mm}$, height $21.4 \mathrm{~mm}$, width (one valve) $6.1 \mathrm{~mm}$. Locality USGS 15264 . USNM 214120 .

8. Length (incomplete) $22.0 \mathrm{~mm}$, height $16.5 \mathrm{~mm}$. Locality USGS 15264. USNM 214121.

10. Right hinge. Length (incomplete) $7.1 \mathrm{~mm}$, height (incomplete) $4.9 \mathrm{~mm}$. Locality USGS 18638 . USNM 214122.

11. Paratype. Length (incomplete) $31 \mathrm{~mm}$, height (incomplete) $22 \mathrm{~mm}$. Locality USGS 2714 . USNM 107399.

13. Lectotype. Length (incomplete) $36 \mathrm{~mm}$, height (incomplete) $21 \mathrm{~mm}$. Locality USGS 2714 . USNM 107396.

12. Crenella porterensis Weaver, p. 45

Length (incomplete) $5.0 \mathrm{~mm}$, height (incomplete) $5.4 \mathrm{~mm}$. Locality USGS 15583. USNM 214123. 

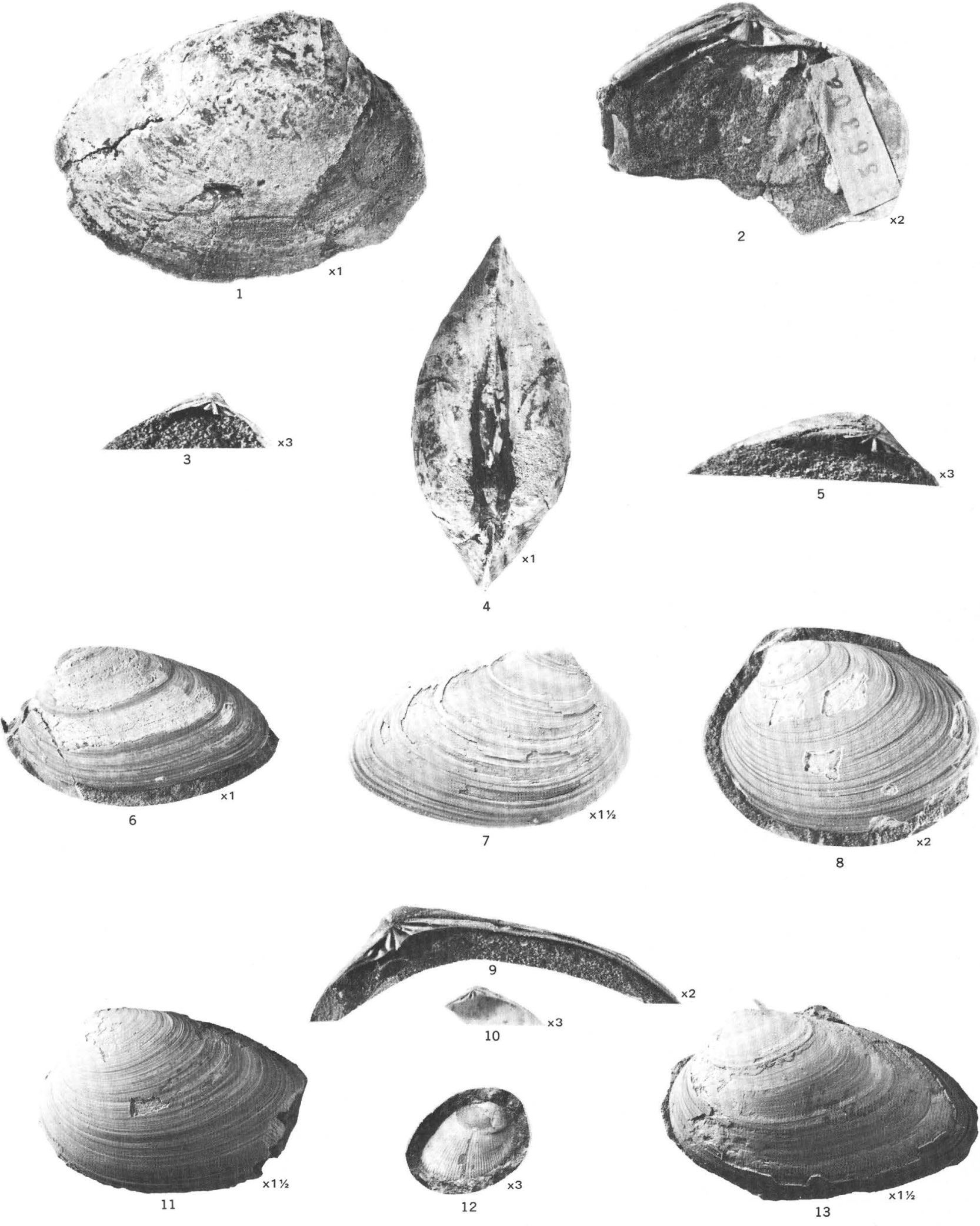

PITAR, CALLISTA, AND CRENELLA 
PLATE 13

Figures 1, 2, 6. Solena (Eosolen) eugenensis (Clark), p. 52

1. Hinge of left valve. Length (incomplete) $87 \mathrm{~mm}$, height (incomplete) $21 \mathrm{~mm}$. Locality USGS 15588 . USNM 214124.

2. Length (incomplete) $70 \mathrm{~mm}$, height (incomplete) $26 \mathrm{~mm}$, width (both valves, compressed) $12.7 \mathrm{~mm}$. Locality USGS 15588. USNM 214125.

6. Interior of left valve. Locality USGS 15588. USNM 214126. 3-5. Solen townsendensis Clark, p. 51

3,5 . Length (incomplete) $54 \mathrm{~mm}$, height (incomplete $14 \mathrm{~mm}$, width (one valve) $3.5 \mathrm{~mm}$. Locality USGS 15310. USNM 214127.

4. Length (incomplete) $21 \mathrm{~mm}$, height $5.6 \mathrm{~mm}$. Locality USGS 15264. USNM 214128. 

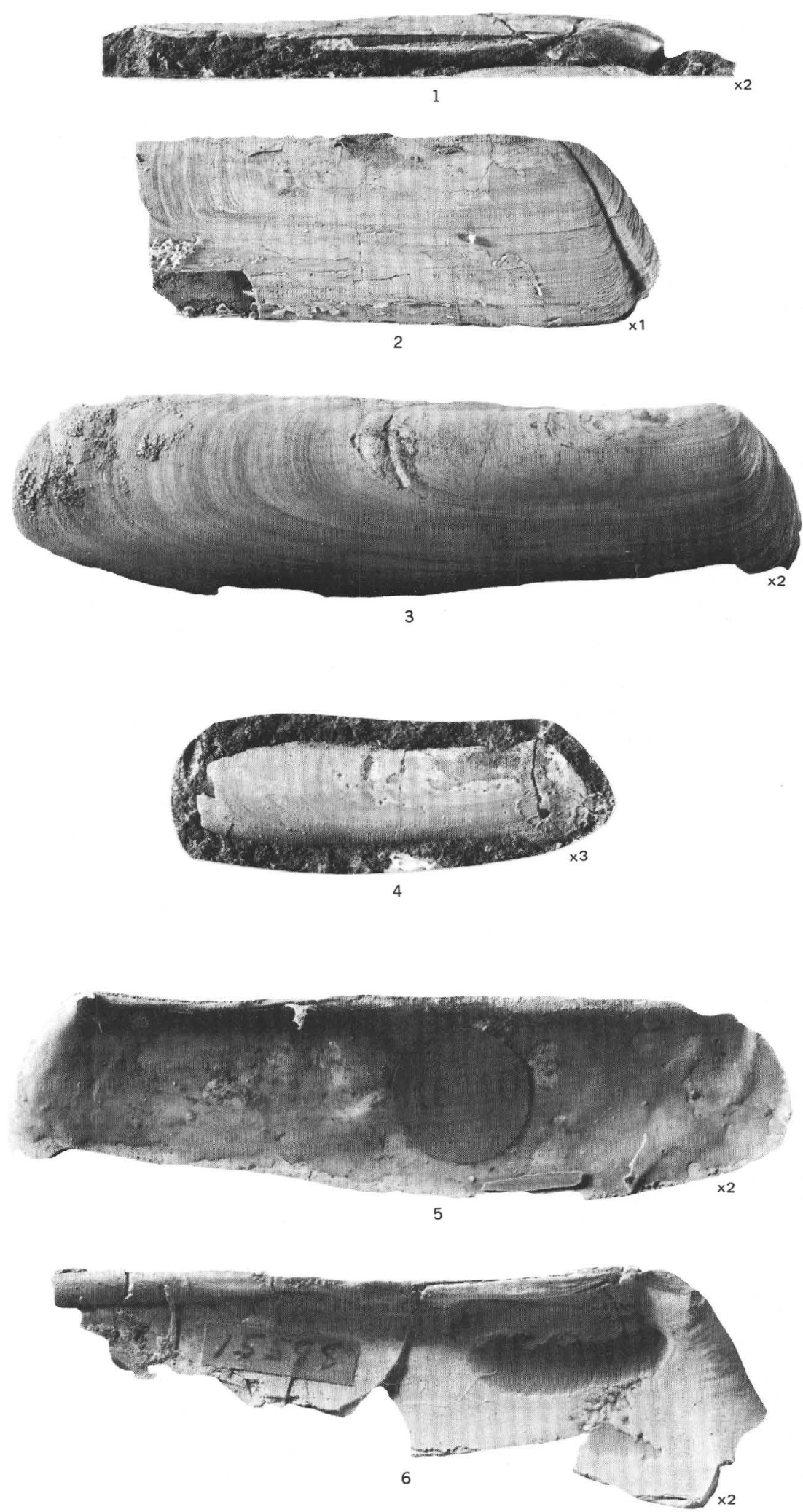

SOLENA AND SOLEN 


\section{PLATE 14}

Figures 1, 2, 9. Spisula (Mactromeris?) veneriformis Clark, p. 50

1. Rubber impression of left hinge. Locality USGS 15516. USNM 214129.

2. Rubber impression of right hinge. Locality USGS 15516. USNM 214130.

9. Length (incomplete) $83.2 \mathrm{~mm}$, height (incomplete) $70.9 \mathrm{~mm}$. Locality USGS 15516. USNM 214131.

3-8, 10, 11. Spisula (Mactromeris) pittsburgensis Clark, p. 49

3. Right hinge. Length (incomplete) $48 \mathrm{~mm}$, height (incomplete) $34 \mathrm{~mm}$, width (one valve) $9.7 \mathrm{~mm}$. Locality USGS 15310d. USNM 214132.

4. Right hinge. Length (incomplete) $49 \mathrm{~mm}$, height (incomplete) $36 \mathrm{~mm}$. Locality USGS 15586. USNM 214133.

5. Left hinge. Length $32.1 \mathrm{~mm}$, height $22.7 \mathrm{~mm}$. Locality USGS 15264 . USNM 214134.

$6,10,11$. Length (incomplete) $56.2 \mathrm{~mm}$, height $39.6 \mathrm{~mm}$, width (both valves) $21.0 \mathrm{~mm}$. Locality USGS 15588. USNM 214135.

7. Right hinge. Locality USGS 18638 . USNM 214136.

8. Left hinge. Locality USGS 15310b. USNM 214137. 


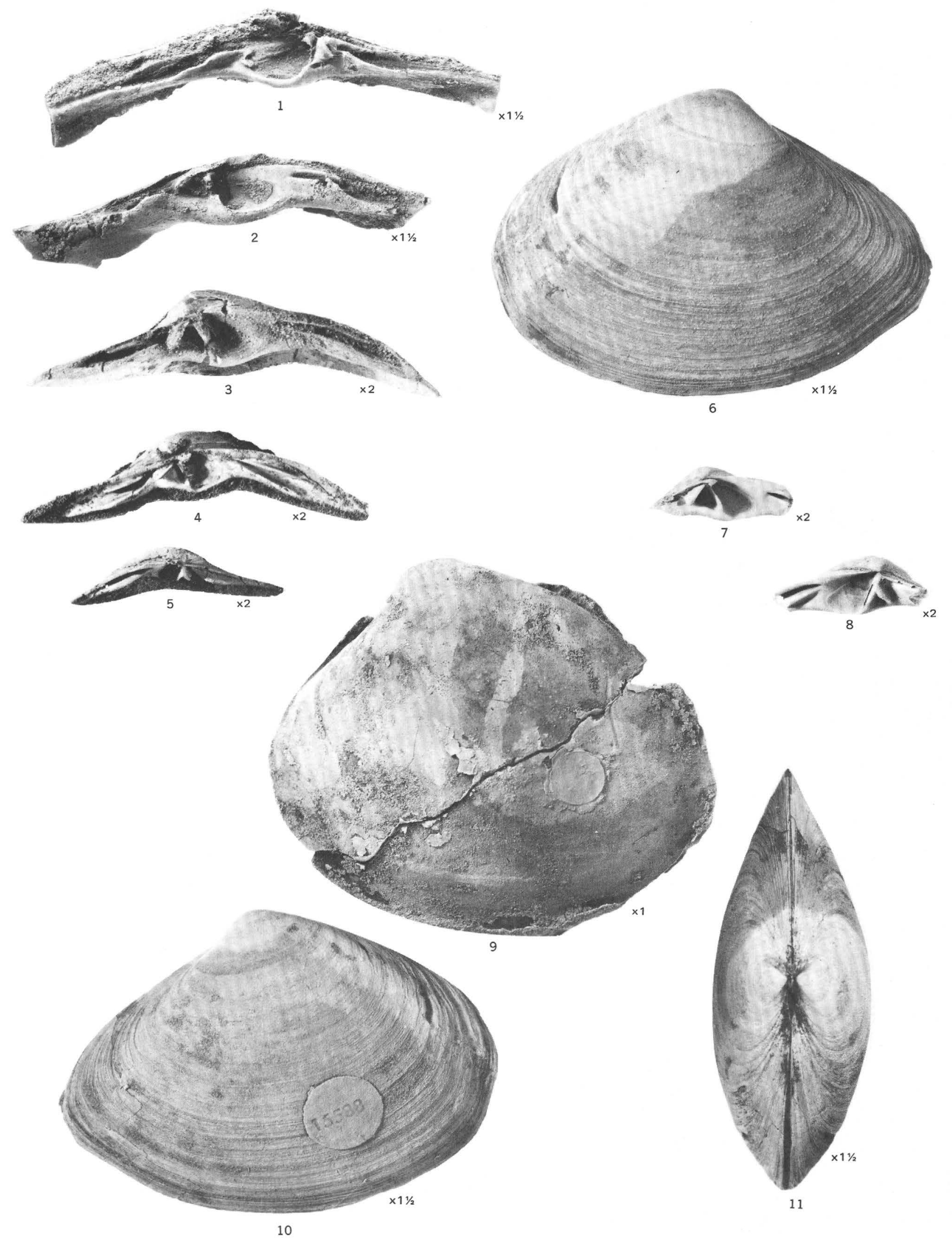

SPISULA 


\section{PLATE 15}

Figures 1-3. Panopea ramonensis Clark, p. 53

1. Length $48.9 \mathrm{~mm}$, height $28.5 \mathrm{~mm}$. Locality USGS 15588 . USNM 214138.

2. Length (incomplete) $42.0 \mathrm{~mm}$, height (incomplete) $27.0 \mathrm{~mm}$, width (both valves) $18.9 \mathrm{~mm}$. Locality USGS 15499. USNM 214139 .

3. Length (incomplete) $45 \mathrm{~mm}$, height (incomplete) $34 \mathrm{~mm}$, width (both valves) $22.6 \mathrm{~mm}$. Locality USGS 15588 . USNM 214140.

4. Aturia angustata (Conrad), p. 54

Height (incomplete) $30 \mathrm{~mm}$, width (incomplete) $30 \mathrm{~mm}$. Locality; roadcut on Scappoose-Vernonia road, about $2 \mathrm{mi}$ from the junction with State Highway 47. USNM 214142.

5. Panopea snohomishensis Clark, p. 52

Length $83.4 \mathrm{~mm}$, height (incomplete) $52.3 \mathrm{~mm}$. Locality USGS 15516. USNM 214141. 

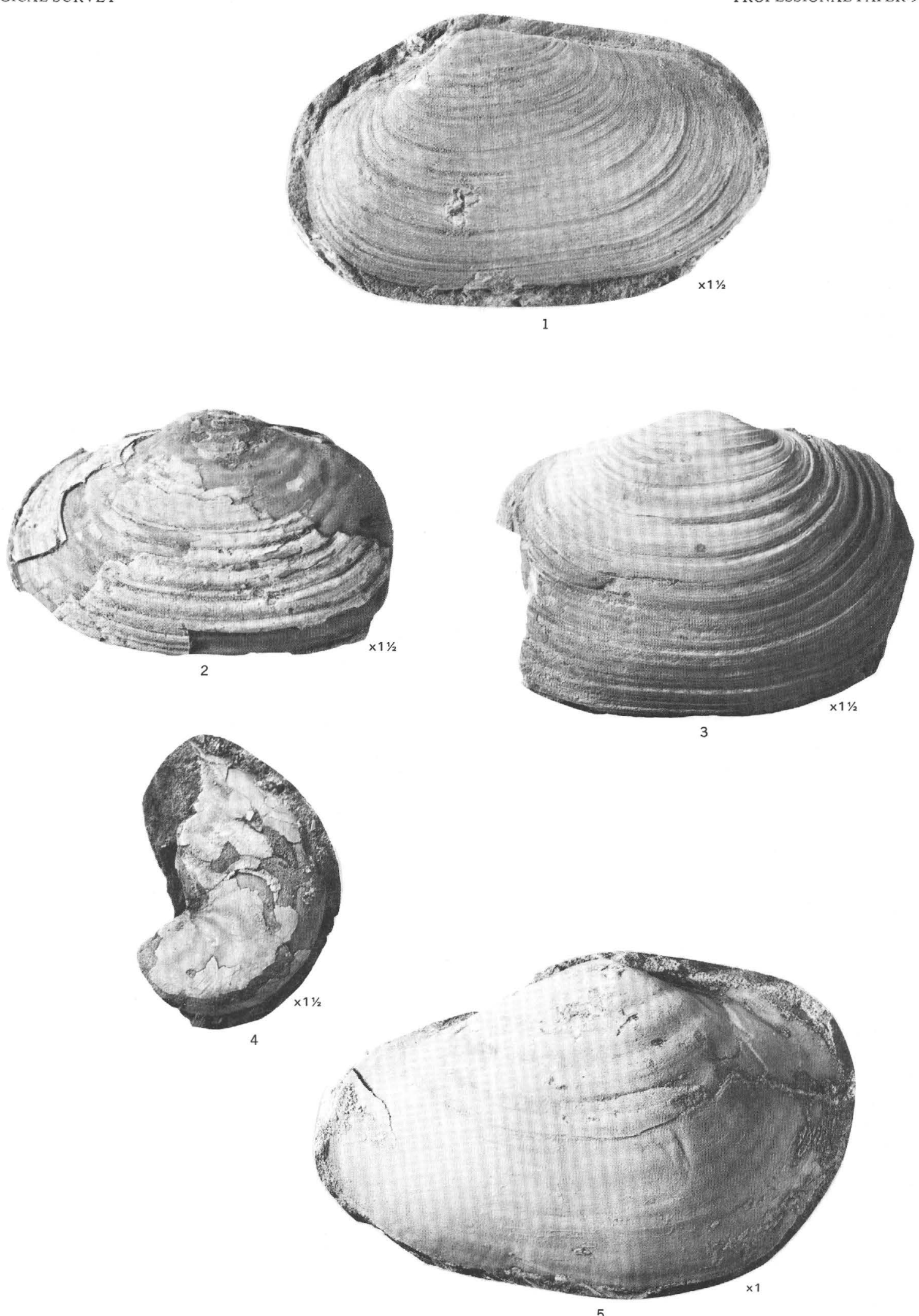

PANOPEA AND ATURIA 


\section{PLATE 16}

Figures 1, 3. Thracia (Thracia) condoni Dall, p. 54

Length (incomplete) $46.7 \mathrm{~mm}$, height (incomplete) $34.7 \mathrm{~mm}$. Locality USGS 15586. USNM 214143.

2, 5. ?Ervilia oregonensis Dall, p. 50

Length (incomplete) $10.5 \mathrm{~mm}$, height (incomplete) $7.0 \mathrm{~mm}$. Locality USGS 18638. USNM 214144.

4, 6-11. Cochlodesma bainbridgensis Clark, p. 53

4, 8. Length (incomplete) $34.1 \mathrm{~mm}$, height (incomplete) $21 \mathrm{~mm}$, width (both valves) $8.2 \mathrm{~mm}$. Locality USGS M3872. USNM 214146.

6. Length (incomplete) $40.0 \mathrm{~mm}$, height (incomplete) $29 \mathrm{~mm}$. Locality USGS 15519. USNM 214145.

7. Length (incomplete) $32.5 \mathrm{~mm}$, height (incomplete) $23.5 \mathrm{~mm}$. Locality USGS 15588. USNM 225305.

9. Condrophore with mineralized resilium. Length (incomplete) $42 \mathrm{~mm}$, height (incomplete) $30 \mathrm{~mm}$. Locality USGS 15588. USNM 214147.

10. Length (incomplete) $53 \mathrm{~mm}$, height (incomplete) $35 \mathrm{~mm}$. Locality USGS 15583 . USNM 214148.

11. Length (incomplete) $32 \mathrm{~mm}$, height (incomplete) $23 \mathrm{~mm}$. Locality USGS 15588 . USNM 214149. 

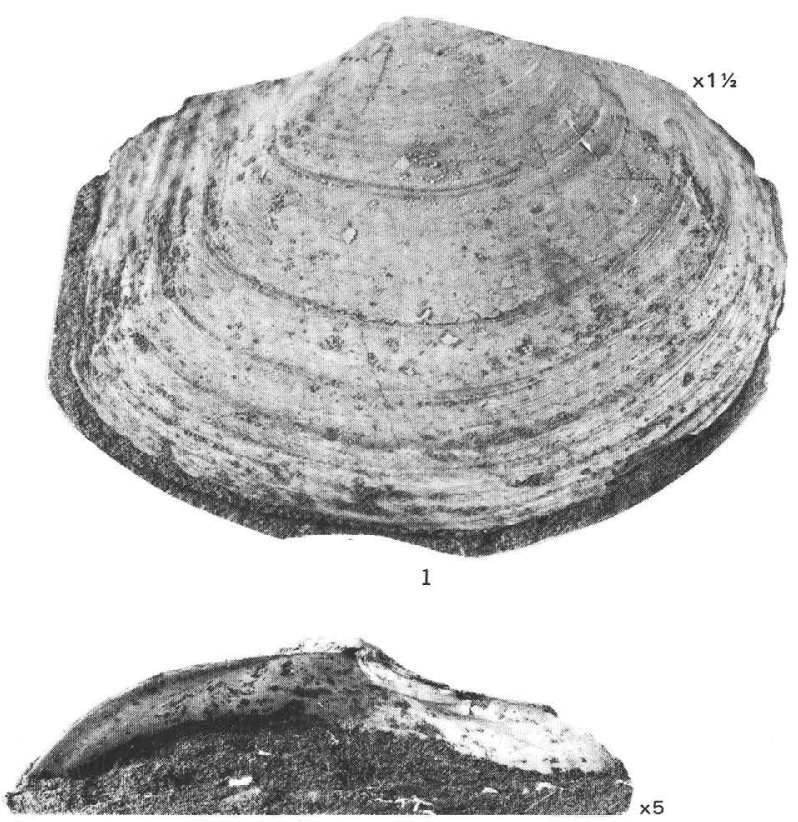

3
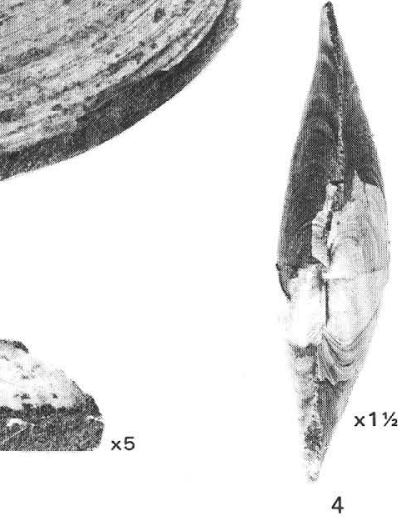

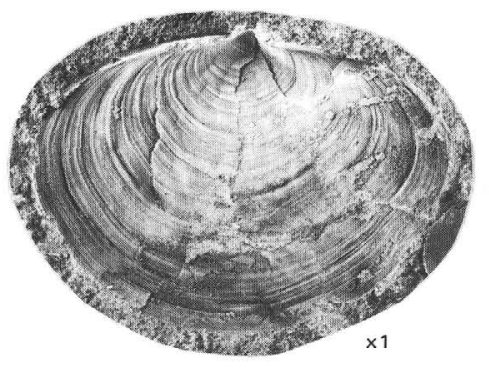

6
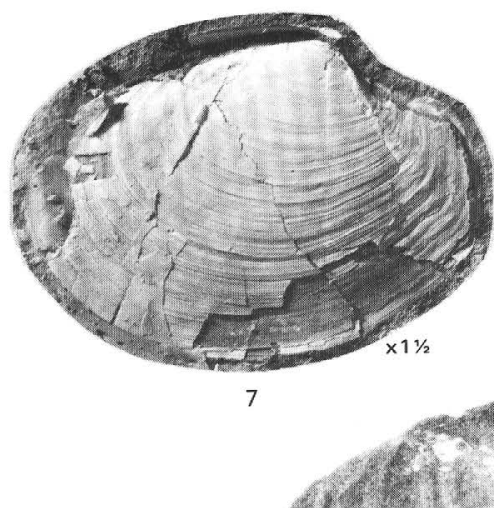
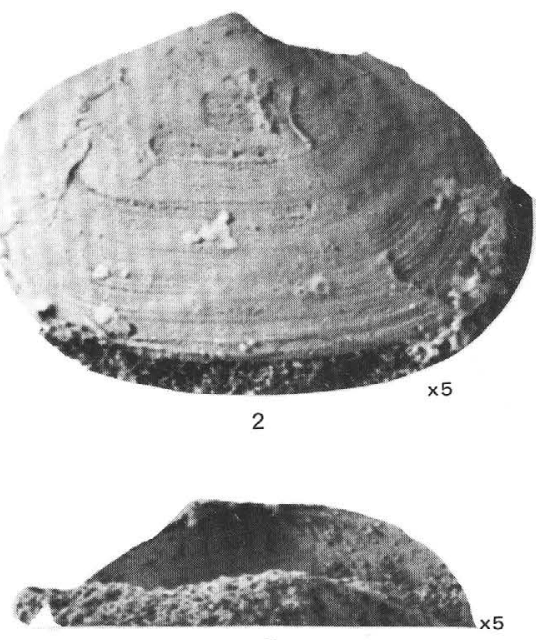

5

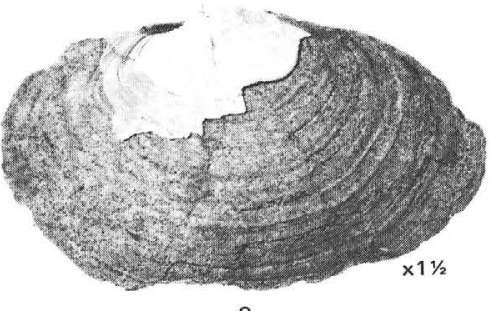

8

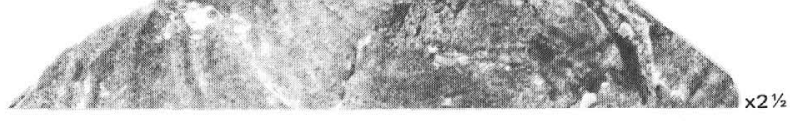

9
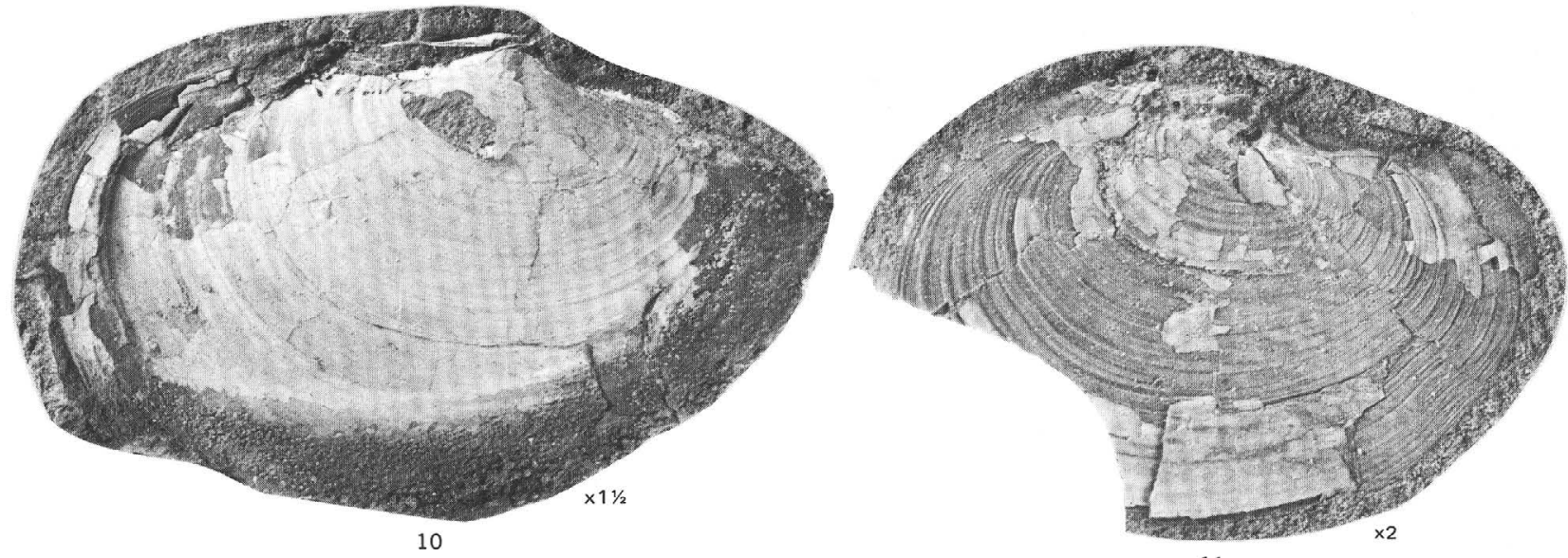

11

THRACIA, ?ER VILIA, AND COCHLODESMA 


\section{PLATE 17}

Two fossiliferous slabs from USGS locality 15310 in the Pittsburg Bluff Formation showing typical groupings of naticids, Molopophorus, Perse, Acila, and Macrocallista. Natural size. 

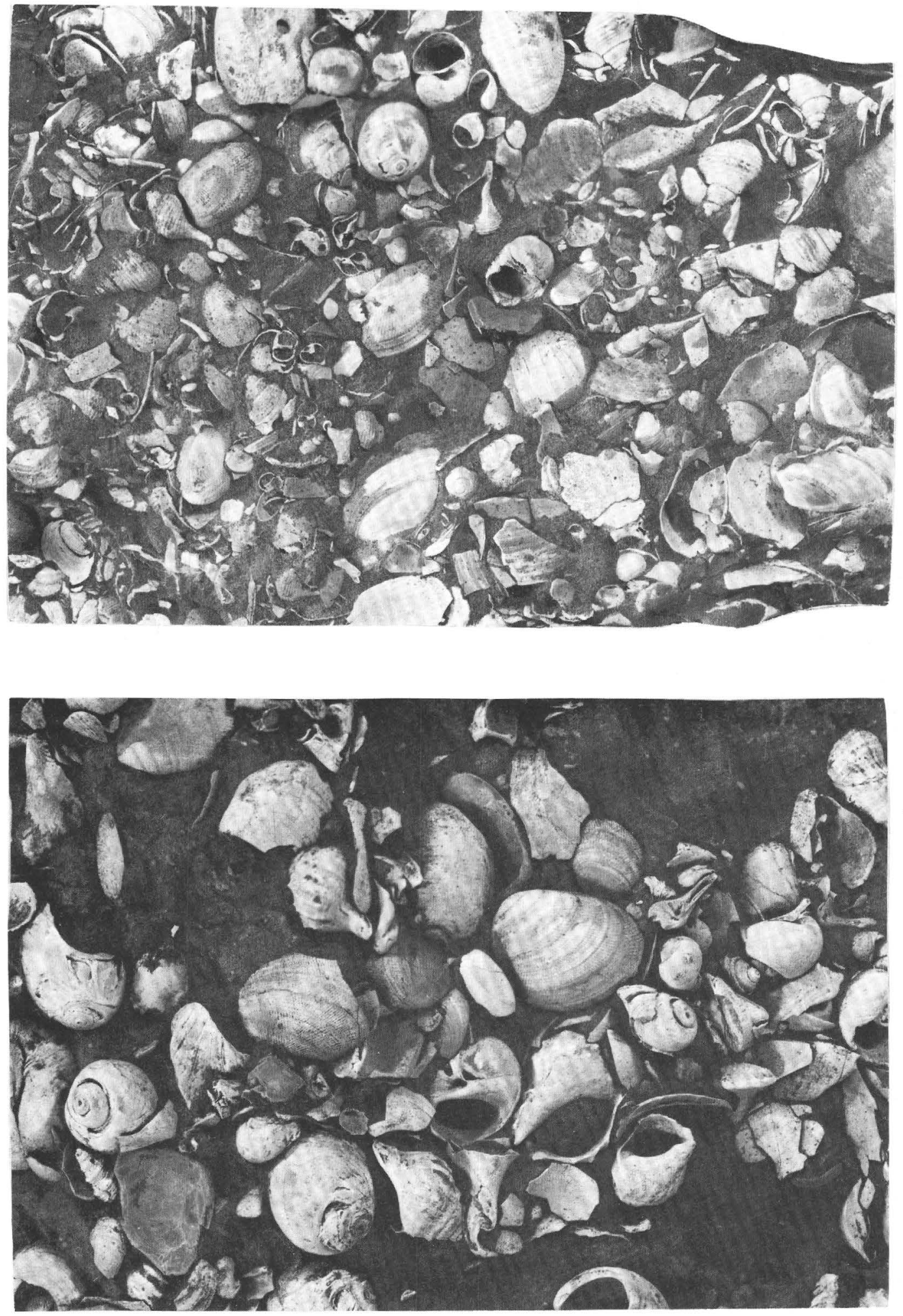

NATICIDS; MOLOPOPHORUS, PERSE, ACILA, AND MACROCALLISTA 


